\title{
AVALIAÇÃO CLÍNICA DE RESTAURAÇÕES DE CLASSE III COM RESINAS COMPOSTAS
}

\section{FÁTIMA CRISTINA DE SÁ}

Tese apresentada à Faculdade de Odontologia de Bauru, da Universidade de São Paulo, como parte dos requisitos para obtenção do título de Doutor em Odontologia, área de Dentística.

(Edição Revisada) 


\section{AVALIAÇÃO CLÍNICA DE RESTAURAÇÕES DE CLASSE III COM RESINAS COMPOSTAS}

\section{FÁTIMA CRISTINA DE SÁ}

Tese apresentada à Faculdade de Odontologia de Bauru, da Universidade de São Paulo, como parte dos requisitos para obtenção do título de Doutor em Odontologia, área de Dentística.

Orientador:

(Edição Revisada)

Prof. Dr. Eduardo Batista Franco 
Sá, Fátima Cristina de

Sa11a

Avaliação clínica de restaurações de classe III com resinas compostas / Fátima Cristina de Sá. - Bauru, 2000. 202p: il.; $30 \mathrm{~cm}$.

Tese (Doutorado) -- Faculdade de Odontologia de Bauru. USP

Orientador: Prof. Dr. Eduardo Batista Franco. 


\section{FÁTIMA CRISTINA DE SÁ}

19 de junho de 1960

Londrina - Paraná

Filiação

1981-1985

1987

1989

1989-1993

1990

1991

1992

1994

1995

1995-2000
Nascimento

Raul Santos de Sá

Ignez Parente de Sá

Curso de Odontologia na Universidade Estadual de Londrina-PR

Professora Auxiliar de Ensino - Nível 1, da Disciplina de Dentística Operatória do Curso de Odontologia da Universidade Estadual de Londrina-PR

Professora Auxiliar de Ensino - Nível 2, da Disciplina de Dentística Operatória do Curso de Odontologia da Universidade Estadual de Londrina-PR

Curso de Pós-Graduação em Dentística, em nível de Mestrado, na Faculdade de Odontologia de Bauru-USP

Professora Auxiliar de Ensino - Nível 3, da Disciplina de Dentística Operatória do Curso de Odontologia da Universidade Estadual de Londrina-PR

Professora Auxiliar de Ensino - Nível 4, da Disciplina de Dentística Operatória do Curso de Odontologia da Universidade Estadual de Londrina-PR

Professora de Ensino Superior da Disciplina de Dentística no Curso de Odontologia da UNOPARUniversidade Norte do Paraná, em Londrina-PR

Professora Assistente - Nível 3, da Disciplina de Dentística Operatória do Curso de Odontologia da Universidade Estadual de Londrina-PR

Professora Assistente - Nível 4, da Disciplina de Dentística Operatória do Curso de Odontologia da Universidade Estadual de Londrina-PR

Curso de Pós-Graduação em Dentística, em nível de Doutorado, na Faculdade de Odontologia de Bauru-USP 
APG-FOB/USP - Associação de Pós-Graduandos da Faculdade de Odontologia de Bauru da Universidade de São Paulo - Sócia Fundadora

IADR - International Association for Dental Research

GBPD - Grupo Brasileiro de Professores de Dentística

$\mathrm{SBPqO}-$ Sociedade Brasileira de Pesquisas Odontológicas 
"As evidências laboratoriais apenas sugerem $\sigma$

potencial do sucesso in vivo..... e permanece muito a ser investigado numa situação clínica"

\author{
M. G. BUONOCORE \\ Retrospections on bonding. Dental Clinics of \\ North America, v.25, p.178-87, 1981.
}


"Quando Deus quer, o homem sonha, a obra nasce".

Fernando Pessoa 
À minha família, que me é muito preciosa, da qual herdei grandes virtudes, como honestidade, caráter, humildade e dignidade, este título é uma pequena retribuição a tudo que fizeram por $\mathrm{mim}$ nesses meus anos de vida.

Com amor, a eles, dedico este trabalho! 
Ao meu orientador, Prof. Dr. Eduardo Batista Franco, meus sinceros agradecimentos pela orientação deste trabalho. Sua segurança, colaboração e competência, trouxeram-me confiança e empenho na busca do meu objetivo. 
Quero expressar minha imensa gratidão a duas pessoas que tiveram participação e contribuição importantíssimas neste estudo, sem as quais não conseguiria realizá-lo, os avaliadores:

Profa. Dra. Maria Fidela de Lima Navarro e Prof. João Batista de Souza Aceitem esse agradecimento e reconhecimento especiais!! 


\section{AGRADECIMENTOS}

Entreguei o meu caminho a DEUS e ELE me conduziu até aqui. Agradeço a ELE e à NOSSA SENHORA por terem me concedido mais esta vitória em minha vida.

$\mathrm{Na}$ época da graduação estudava pelos seus livros publicados, sentia uma enorme admiração, porém achava que conhecê-lo seria uma coisa impossível de acontecer. Hoje, concluindo meu curso de Doutorado tenho o orgulho de dizer a todos que tive o privilégio de conviver e aprender muito com os ensinamentos de um dos maiores mestres da Odontologia mundial,

\section{Muito obrigada Prof. Dr. José Mondelli!}

À Profa. Dra. Maria Fidela de Lima Navarro, exemplo de mulher de fibra, por quem tenho grande admiração. Grande figura humana em quem me espelho, procuro ser pelo menos um pouquinho do que é, grande mestre e incansável incentivadora de seus alunos,

\section{Minha gratidão!!}

À ela também quero deixar aqui registrado um agradecimento especial por ter sido a mentora científica dessa avaliação, assunto aliás que domina muitíssimo bem dentre muitos outros, pois foi até motivo de sua Tese de Livre Docência em 1981. 


\section{AGRADEÇO AINDA:}

À Faculdade de Odontologia de Bauru - Universidade de São Paulo, na pessoa do seu diretor, Prof. Dr. Aymar Pavarini e do Presidente da Comissão de Pós-Graduação, Prof. Dr. Luiz Fernando Pegoraro, por poder fazer parte do corpo discente desta conceituada Instituição.

À Universidade Estadual de Londrina, pela oportunidade que me concedeu de realizar um ideal de vida profissional.

À CAPES/PICD pelo suporte financeiro no transcorrer deste Curso.

Aos Professores do Departamento de Dentística, Doutores José Mondelli, Aquira Ishikiriama, Maria Fidela de Lima Navarro, João Lúcio Coradazzi, Carlos Eduardo Francischone, José Carlos Pereira, Eduardo Batista Franco, Mário Honorato da Silva e Souza Jr., Ricardo Marins de Carvalho e Rafael Francisco Lia Mondelli, com os quais tive o orgulho e o privilégio de conviver durante o curso, por toda contribuição científica valiosa e amizade em todos os momentos.

Aos meus colegas, os professores da Disciplina de Dentística da Universidade Estadual de Londrina, pela compreensão do longo tempo ausente, pelo coleguismo no período do meu desligamento assumindo minhas atividades. 
Aos meus colegas, professores da Disciplina de Dentística da Universidade Norte do Paraná, que acompanharam meus momentos de ansiedade, na conclusão do trabalho, meu reconhecimento e agradecimento.

Ao Professor José Roberto Pereira Lauris, pelo profundo conhecimento e eficiência na realização da análise estatística e orientação na compreensão dos resultados deste trabalho.

Ao Prof. Dr. Ruy Gastaldoni Jaeger, Professor Associado do Departamento de Patologia Bucal, do Departamento de Estomatologia, da Faculdade de Odontologia da Universidade de São Paulo, pela inestimável colaboração nos trabalhos de microscopia eletrônica de varredura e respectivas fotografias, realizando com enorme competência e pontualidade.

Ao Departamento de Estomatologia da Faculdade de Odontologia da Universidade de São Paulo, nas pessoas do Prof. Dr. Ney Araújo e da Profa. Dra. Vera Cavalcanti de Araújo, por abrirem as portas e colocarem o referido Departamento à minha disposição, com gentilezas e receptividade ímpares, propiciando que eu concluísse uma importante fase desse estudo, a Microscopia Eletrônica de Varredura.

À Supervisora Técnica do Serviço de Documentação e Divulgação da Biblioteca da FOB-USP, Valéria Cristina Trindade Ferraz, pela grande ajuda, orientação e correção do texto e das referências bibliográficas. 
Aos funcionários da Pós-Graduação, do Serviço de Biblioteca e Documentação da FOB-USP e da Associação de Pós-Graduandos também da FOB-USP, pelas gentilezas, pela amizade e pela atenção com que sempre me atenderam.

Aos funcionários do Departamento de Dentística da Faculdade de Odontologia de Bauru - USP, pela maneira cordial com que sempre me trataram.

Ao Nelson, pela ajuda na confecção dos modelos de resina epóxica, que possibilitaram a execução da Microscopia Eletrônica de Varredura; amigo sempre pronto para ajudar nos trabalhos.

À Ângela e à Eloísa, funcionárias do Departamento de Dentística, pela amizade.

Aos meus amigos do curso de doutorado, Adriana, Ângela, João, Margareth, Maria Cecília, Renata e Rogério, com os quais convivi e compartilhei momentos bons e difíceis, unidos por um ideal comum, o aprimoramento científico e humano, pela amizade e fraternidade. 


\section{SUMÁRIO}

LISTA DE FIGURAS...........................................................................................

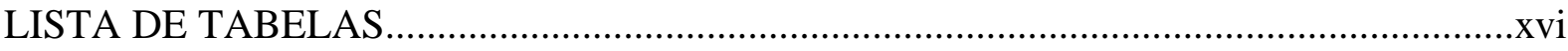

LISTA DE ABREVIATURAS E SÍMBOLOS................................................................

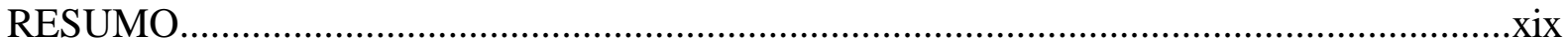

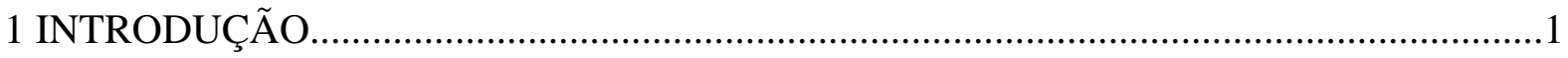

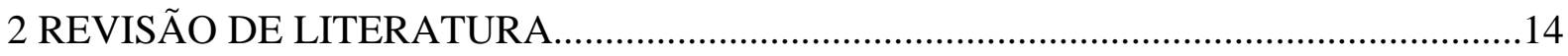

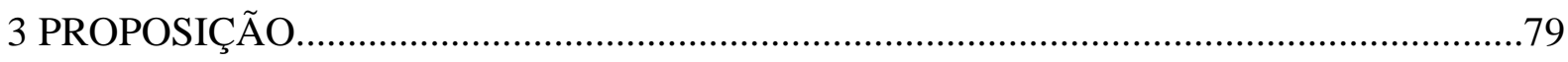

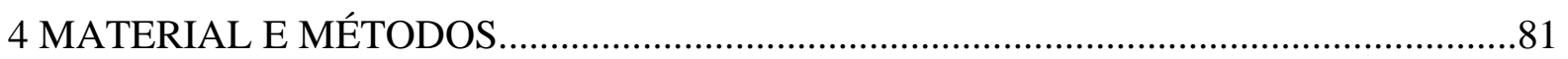

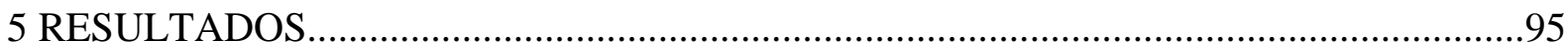

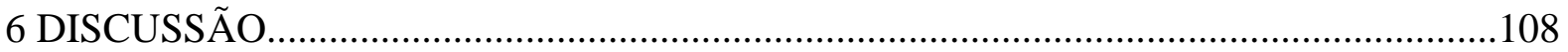

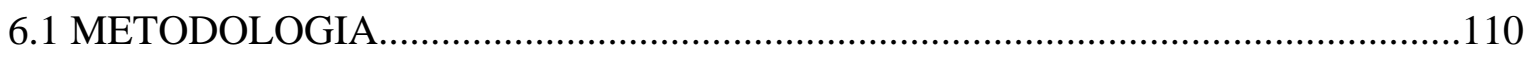

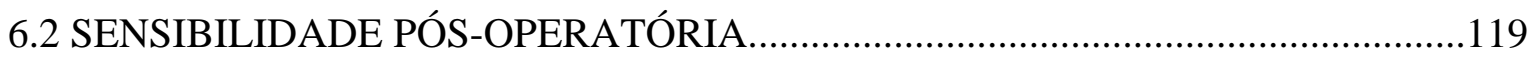

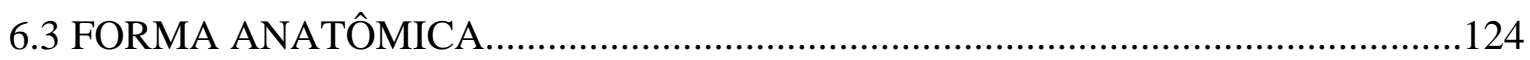

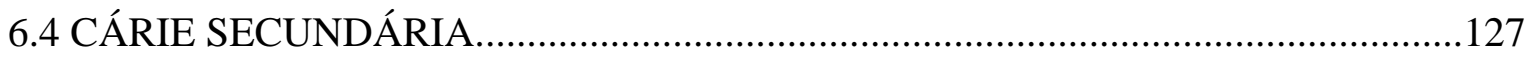

6.5 INTEGRIDADE MARGINAL/DESCOLORAÇÃO MARGINAL ............................131

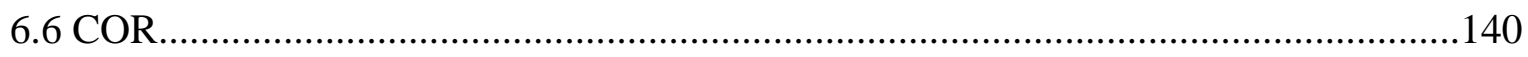

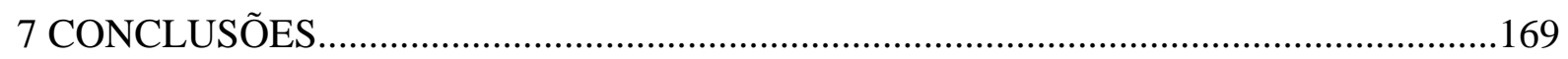

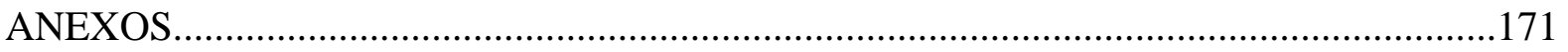

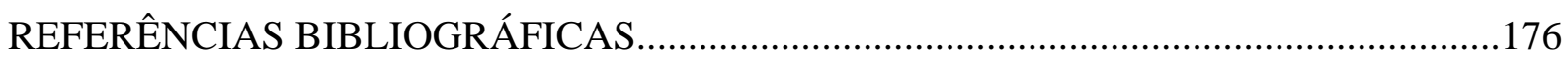

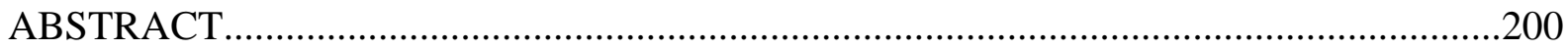




\section{LISTA DE FIGURAS}

Figura 5.1 - Aspecto do conjunto de restaurações em diferentes períodos de tempo. A restauração na mesial do dente 11 foi feita com a resina composta Z-100 e na mesial do dente 21, com Fill Magic. Não foi anotada alteração de cor nas restaurações. A - Inicial; B - "Baseline"; C - 6 meses; D - 1 ano; E - 2 anos. .98

Figura 5.2 - Aspecto do conjunto de restaurações em diferentes períodos de tempo. A restauração na mesial do dente 11 foi feita com a resina composta Fill Magic e na mesial do dente 21, com Z-100. Foi anotada alteração de cor na restauração do dente 21, já aos 6 meses de avaliação. A - Inicial; B - "Baseline"; C - 6 meses; D - 1 ano; E - 2 anos.

Figura 5.3 - Gráfico representativo das porcentagens de alteração de cor, no "baseline", para a resina composta $\mathrm{Z}-100$. 104

Figura 5.4 - Gráfico representativo das porcentagens de alteração de cor, no "baseline”, para a resina composta Fill Magic 104

Figura 5.5 - Gráfico representativo das porcentagens de alteração de cor, na avaliação de 6 meses, para a resina composta Z-100 105

Figura 5.6 - Gráfico representativo das porcentagens de alteração de cor, na avaliação de 6 meses, para a resina composta Fill Magic. 105

Figura 5.7 - Gráfico representativo das porcentagens de alteração de cor, na avaliação de 1 ano, para a resina composta Z-100. 106

Figura 5.8 - Gráfico representativo das porcentagens de alteração de cor, na avaliação de 1 ano, para a resina composta Fill Magic. 106 
Figura 5.9 - Gráfico representativo das porcentagens de alteração de cor, na avaliação de 2 anos, para a resina composta Z-100.

Figura 5.10 - Gráfico representativo das porcentagens de alteração de cor, na avaliação de 2 anos, para a resina composta Fill Magic. 107

Figura 6.1 - Fotomicrografia do aspecto das restaurações com Z-100 (dente 21 - à esquerda) e com Fill Magic (dente 22 - à direita), com aumento padrão de $40 X$

Figura 6.2 - Fotomicrografia do aspecto das restaurações com Z-100 (dente 22 - à direita) e com Fill Magic (dente 21 - à esquerda), com aumento padrão de $40 X$ 149

Figura 6.3 - Fotomicrografia do aspecto das restaurações com Z-100 (dente 11 - à direita) e com Fill Magic (dente 12 - à esquerda), com aumento padrão de $40 X$ 151

Figura 6.4 - Fotomicrografia do aspecto das restaurações com Z-100 (dente 12 - à esquerda) e com Fill Magic (dente 11 - à direita), com aumento padrão de $40 X$ 153

Figura 6.5 - Fotomicrografia do aspecto das restaurações com Z-100 (dente 12 - à esquerda) e com Fill Magic (dente 11 - à direita), com aumento padrão de $40 X$ 155 


\section{LISTA DE TABELAS}

Tabela 5.1 - Resultados obtidos no "baseline"

Tabela 5.2 - Resultados obtidos na avaliação de 6 meses......................................................96

Tabela 5.3 - Resultados obtidos na avaliação de 1 ano.........................................................96

Tabela 5.4 - Resultados obtidos na avaliação de 2 anos.......................................................96

Tabela 5.5 - Histórico das restaurações com resina composta Fill Magic no período de 2 anos.

Tabela 5.6 - Histórico das restaurações com resina composta Z-100 no período de 2 anos 100

Tabela 5.7 - Restaurações com resina composta Fill Magic avaliadas $(n=35)$ 101

Tabela 5.8 - Restaurações com resina composta Z-100 avaliadas $(n=35)$ 102

Tabela 5.9 - Comportamento das restaurações com relação à cor. 102 


\section{LISTA DE ABREVIATURAS E SÍMBOLOS}

cm centímetro

Com. Comércio

Co. Company

C.S. Cárie secundária

CNS Conselho Nacional de Saúde

D.M. Descoloração marginal

FDI Federação Dentária Internacional

F.A. Forma anatômica

g grama

${ }^{0} \mathrm{C} \quad$ Grau Celsius

Ind. Indústria

I.M. Integridade marginal

Ltda. Limitada

L Lingual

Mfg. Manufacturing

$>\quad$ maior

$<\quad$ menor

Mpa megapascal

m metro

$\mu \quad$ micra

$\mu \mathrm{m} \quad$ micrometro

MEV Microscópio Eletrônico de Varredura 


\begin{tabular}{|c|c|}
\hline $\mathrm{mm}$ & milímetro \\
\hline $\mathrm{mW} / \mathrm{cm}^{2}$ & miliwatt por centímetro quadrado \\
\hline $\mathrm{nm}$ & nanômetro \\
\hline $\mathrm{n}$ & número \\
\hline MO & mésio-oclusal \\
\hline DO & disto-oclusal \\
\hline MOD & mésio-ocluso-distal \\
\hline OMS & Organização Mundial da Saúde \\
\hline$\%$ & porcentagem \\
\hline $\mathrm{pH}$ & potencial hidrogeniônico \\
\hline $\mathrm{P}$ & Proteção \\
\hline $\mathrm{Kv}$ & quilovolt \\
\hline $\mathrm{rpm}$ & rotação por minuto \\
\hline S.A. & Sociedade Anônima \\
\hline S.P.O. & Sensibilidade pós-operatória \\
\hline USPHS & United States Public Health Service (Serviço de Saúde Pública dos Estados \\
\hline \multicolumn{2}{|l|}{ Unidos) } \\
\hline $\mathrm{V}$ & vestibular \\
\hline$X$ & vezes \\
\hline
\end{tabular}




\section{RESUMO}

Avaliou-se clinicamente 2 resinas compostas (Z-100 e Fill Magic), quanto a: sensibilidade pós-operatória, forma anatômica, cárie secundária, integridade marginal, descoloração marginal, cor e a influência do período de observação ("baseline”, 6 meses, 1 ano e 2 anos) no desempenho desses fatores. Participaram 43 pacientes, que receberam 2 restaurações de classe III, 1 de cada resina, totalizando 86 restaurações. Fez-se a avaliação inicial das restaurações, o "baseline", 7 dias após a sua confecção, por 2 examinadores. Cada item recebia um escore em 3 níveis: bom (0), aceitável (1) e inaceitável (2). Somente para a cárie considerava-se 2 níveis: ausente (0) e presente (1). Fotografou-se as restaurações em todos os períodos de observação. Obteve-se moldagens das restaurações de 10 pacientes, para análise e fotografias em Microscópio Eletrônico de Varredura, com aumento de $40 \mathrm{X}$. Dos 43 pacientes, 8 não retornaram, assim, analisou-se estatisticamente pelo teste exato de Fisher, 70 restaurações. No baseline, 34 restaurações com a resina composta Z-100 e 35 com a Fill Magic receberam escores zero em todas as categorias, com exceção de 1 caso com a resina Z-100 que recebeu escore 1 para o critério cor. Para esse mesmo critério, aos 6 meses, 35 restaurações com a Fill Magic e com a Z-100, 31 restaurações receberam escores zero e 4 mereceram escores 1. Em 1 ano, 31 restaurações com a Z-100 ficaram com escores zero e 4 com escores 1; 34 restaurações com Fill Magic obtiveram escores zero e 1 obteve escore 1, com relação à cor. Aos 2 anos, também com relação à cor, para 3 restaurações com Z-100 e para 1 com Fill Magic atribuíram-se escores 1; escores 0 foram aplicados a 32 das restaurações de Z-100 e a 34 das de Fill Magic. Exceto para a categoria cor, que sofreu mudanças com o passar do tempo, todas as restaurações 
receberam escores 0 na avaliação "baseline", 6 meses, 1 ano e 2 anos. Nenhum escore 2 foi anotado. Não observou-se diferença estatisticamente significante entre as 2 resinas compostas, aceitando-se a hipótese de igualdade entre as mesmas. 


\section{INTRODUÇÃO}

Avaliando-se a evolução dos materiais odontológicos, para restaurações estéticas diretas, pode-se afirmar que pouco progresso obteve-se até os anos 40. Numa retrospectiva dos materiais disponíveis naquela época, verifica-se que o cimento de silicato era, praticamente, o único que se prestava àquelas finalidades, de maneira insatisfatória, em função de limitadas opções de cores, alta solubilidade na cavidade bucal e uma técnica que demandava tempo e conhecimentos para a otimização dos resultados.

A grande inovação na Odontologia moderna ocorreu, sem dúvida, a partir da introdução das resinas compostas. Isso só foi possível graças às pesquisas iniciadas por BUONOCORE ${ }^{27}$, em 1955, relacionadas com o ataque ácido do esmalte dentário e depois complementadas por BOWEN ${ }^{16}$, em 1963, que aperfeiçoou a formulação das resinas acrílicas. Assim, sempre que se fala, se escreve ou se pesquisa sobre resinas compostas, o nome desses dois grandes precursores estão intimamente ligados. O seu uso cresceu rapidamente, mercê de uma rápida evolução e hoje pode-se dizer, com toda segurança, que a maioria das restaurações estéticas são realizadas com resinas compostas, que vieram substituir, com inúmeras vantagens, os materiais utilizados largamente nos idos de 50, como as resinas acrílicas, o cimento de silicato e outros cimentos assemelhados. Mesmo assim, esses cimentos continuaram a ser utilizados durante muito tempo.

É oportuno lembrar que na fase de introdução das resinas 
compostas, as opções de cores eram também limitadas e a sua manipulação e inserção na cavidade preparada, demandava um tempo de trabalho restrito, devido à sua polimerização quimicamente ativada. Entretanto, as suas propriedades físicas e mecânicas em relação às resinas acrílicas eram sensivelmente superiores. Essas qualidades permitiam o seu uso em dentes anteriores, com extensas perdas de estrutura, pois apresentavam grande resistência ao esforço mastigatório.

O uso desse material, em seu início embora precário, veio preencher uma lacuna até então existente, com relação a um material estético utilizável em dentes anteriores. Mercê do seu rápido aperfeiçoamento, sua utilização cresceu significativamente, permitindo dizer-se que a maioria das restaurações estéticas, há muito tempo, são realizadas com resinas compostas substituindo assim, com muitas vantagens, as resinas acrílicas, o cimento de silicato e outros cimentos utilizados como materiais de uso direto.

Hoje, pode-se avaliar a enorme dificuldade que os clínicos enfrentavam para a confecção de restaurações diretas, utilizando o cimento de silicato. Este material requeria técnica de manipulação meticulosa, inserção criteriosa, com poucas opções de cores e limitação do uso em cavidades de classe III e V. Da mesma forma, pode-se reconhecer a dificuldade para o uso das primeiras resinas acrílicas, precursoras das resinas compostas atuais, que apesar das propaladas propriedades estéticas e de manipulação fácil, não corresponderam à expectativa, não só pela forma inadequada de indicação, como também por limitações inerentes ao próprio material, principalmente devido ao alto coeficiente de expansão térmica linear, descoloração marginal e alta recidiva de cárie.

Grande melhoria ocorreu com o advento da luz halógena para a 
polimerização das resinas compostas, que resultou em maior resistência ao desgaste quando comparada com as resinas auto-polimerizáveis, ocorrência essa observada clinicamente por WILDER; MAY; LEINFELDER ${ }^{196}$ (1984). Com a utilização desse meio físico, tornou-se imensamente facilitado o tempo de trabalho, a manipulação, a inserção e escultura e polimerização das resinas compostas nos preparos cavitários.

A ciência odontológica atual tem muito da sua atenção voltada, principalmente para a prevenção e diagnóstico precoce das alterações que podem afetar o sistema estomatognático. Porém, quando as lesões já estão instaladas, o tratamento dessas patologias torna-se necessário. No caso específico das lesões cariosas que originam preparos cavitários de classe III, em dentes anteriores, a estética é muito exigida e o profissional deve possuir, além de habilidade técnica, conhecimentos do material restaurador que irá utilizar, pois destes fatores dependerá a qualidade da restauração. Esta qualidade pode ser afetada por muitos outros fatores, os quais podemos observar em avaliações clínicas: idade dos pacientes, pH da saliva, dieta, higiene oral, tamanho e acesso à cavidade.

Sabe-se que na cavidade bucal as condições sumamente adversas de umidade, variações térmicas e de $\mathrm{pH}$, têm comprometimento sobre a estabilidade dimensional e consequente infiltração marginal nas restaurações. Levando em consideração esses fatores, pesquisas inovadoras têm proporcionado rápidas mudanças relacionadas à adesão das resinas compostas aos tecidos dentais. A busca de um material ideal tem motivado pesquisadores e fabricantes a desenvolver novos produtos de modo a obter restaurações que apresentem uma efetiva adesão físico-química às estruturas dentais.

A adesão é definida por RETIEF ${ }^{139}$ (1970) como uma atração molecular exercida entre superfícies e corpos em contato ou atração entre moléculas numa 
interface. Quando moléculas diferentes são atraídas entre si, esta força é denominada adesão. Para produzir essa adesão acrescenta-se um material denominado adesivo e, ao substrato onde ele é aplicado dá-se o nome de aderente. A interface é a zona entre as substâncias que estão interagindo.

Idealmente, as propriedades físicas e mecânicas de nossos adesivos e resinas compostas deveriam imitar as propriedades do esmalte e da dentina ${ }^{82}$. No entanto, isso nem sempre acontece.

Com relação à performance dos adesivos lançados ultimamente, VAN MEERBEEK et al. ${ }^{191}$ observaram que foram significativamente melhorados, permitindo a confecção de restaurações adesivas com melhor prognóstico de sucesso clínico e aduziram que a maioria dos modernos sistemas adesivos são superiores aos seus antecessores, especialmente em termos de retenção, que até recentemente, era a principal causa da prematura falha clínica.

O desenvolvimento de novos materiais com características adesivas tem possibilitado, ainda, ao profissional, a preservação de maior quantidade de estrutura dentária durante o procedimento de preparo da cavidade, diminuindo a infiltração marginal e a reincidência de cáries ${ }^{121}$.

O comportamento clínico dos diversos materiais restauradores disponíveis comercialmente varia e difere uns dos outros.

A evolução das resinas compostas é contínua, pois os CirurgiõesDentistas estão sempre exigindo maior facilidade de manipulação e propriedades superiores desses materiais estéticos ${ }^{138}$. As resinas compostas, dentre os materiais odontológicos, são as que continuam a atrair muitas pesquisas clínicas. 
Como em outras áreas, a Odontologia também tem alcançado alto nível científico e desenvolvimento tecnológico. E é importante que se reconheça que o futuro não existe independentemente do presente ${ }^{82}$.

Os testes de laboratório para avaliar materiais estéticos têm sido de ampla e fundamental importância. A necessidade de se conhecer a resistência à compressão e a dureza superficial são alguns testes que se destacam em pesquisas laboratoriais. Estas permitem que seja selecionado o material mais adequado para casos específicos indicando o seu potencial de utilização. Entretanto, o seu emprego em clínica, muitas vezes, não corresponde ao que dele se esperava baseado em testes ou informações oriundas de estudos in vitro $^{67}$.

Avaliações in vitro das propriedades mecânicas dos materiais dentários são muito importantes e necessárias para melhorar seu comportamento clínico. No entanto, os resultados desses experimentos não são garantia de que o uso do material, em clínica, tenha o mesmo desempenho, em função de variações encontradas na cavidade bucal. À idêntica conclusão chegaram LEINFELDER et al. ${ }^{102}$ e RYGE; CVAR ${ }^{147}$ quando afirmaram que testes laboratoriais somente são insuficientes para predizer o comportamento clínico de certos tipos de materiais restauradores.

Quanto à contração de polimerização, outra vilã antiga das resinas compostas e fenômeno que ocorre em todas elas, PERDIGÃO et al. ${ }^{131}$ comentam, em trabalho de pesquisa, que ela continua sendo o maior problema na adesão dental e que, apesar da agressiva propaganda, o clínico deve prevenir-se e conhecer as limitações das resinas. Acrescentam também, que embora os modernos adesivos venham sendo aperfeiçoados em curto espaço de tempo, nenhum dos modernos sistemas, no entanto, apresenta ainda garantia 
de selar hermeticamente as restaurações, com margens livres de descoloração por longo tempo.

A preocupação com o desempenho clínico de um material restaurador estético é conhecida há várias décadas. Um trabalho de PAFFENBARGER ${ }^{129}$, de 1940, demonstra este fato, ao procurar verificar os resultados clínicos de restaurações de cimento de silicato. A partir dessa época, os pesquisadores se preocuparam em desenvolver novos materiais que suprissem as falhas constatadas nas restaurações com esse cimento. Assim é que com o decorrer do tempo, novas composições de materiais restauradores foram surgindo, como a resina acrílica, resina composta e cimento de ionômero de vidro ${ }^{67}$.

A pesquisa clínica deve sempre ser desenvolvida para testar materiais que chegam todos os dias no mercado odontológico. Só assim os fabricantes irão, cada vez mais, se preocupar em lançar materiais de qualidade, respeitando os profissionais e seus pacientes.

Ao se desenvolver uma pesquisa clínica, deve-se atentar para a ética na pesquisa odontológica. Em outubro de 1996, o Conselho Nacional de Saúde publicou a Resolução n. 196/96, que baseia-se nos preceitos da Bioética e em diretrizes internacionais da OMS, que consideram que toda pesquisa envolvendo seres humanos deve ser conduzida de acordo com três princípios, na seguinte ordem: beneficência, autonomia e justiça ${ }^{136}$.

O princípio da beneficência refere-se à obrigação ética de maximizar benefícios e minimizar danos ou prejuízos; nasce do reconhecimento do bem supremo que é a vida humana e do reconhecimento de sua dignidade, que transcende seus aspectos materiais, qualquer que seja a situação biológica, econômica ou cultural em que o indivíduo se encontre ${ }^{136}$. 
O princípio da autonomia, decorrente do princípio que o antecede, reconhece o respeito devido às pessoas na sua capacidade de decidirem livremente sobre sua participação ou não na pesquisa que lhes está sendo proposta ${ }^{136}$.

O princípio da justiça refere-se à obrigação ética de tratar cada pessoa de acordo com o que é moralmente certo e adequado, dando a cada pessoa o que lhe é devido $^{136}$.

A partir desses princípios, pode-se construir uma nova postura ética na pesquisa com seres humanos, marca da Resolução n. 196/96 do CNS. Esta mostra como obter, do "sujeito da pesquisa", seu consentimento livre e esclarecido para colaborar ou não com a pesquisa, ou ainda como proceder para elaborar um Protocolo de Pesquisa a ser submetido a um Comitê de Ética em Pesquisa, que deverá existir em toda entidade de ensino, empresarial ou associativa que promova pesquisas com seres humanos ${ }^{136}$.

A Bioética ensina que se deve deixar para trás a obsoleta visão de que o sujeito da pesquisa, principalmente paciente de instituição pública de ensino e/ou assistência odontológica, seja apenas boca, dentes, incapaz de decidir o que é melhor para sua saúde ou entender os propósitos da pesquisa. Dentes ou tecidos humanos, mesmo que removidos frente a indicações terapêuticas, não deixam de pertencer a seus "donos de origem", necessitando-se sempre que possível, autorização prévia para seu uso em pesquisa $^{136}$.

Muitas pesquisas são realizadas sem responsabilidade e senso ético, visando apenas os resultados e a própria projeção do pesquisador.

Dentre os materiais dentários, atualmente lançados no mercado, as resinas compostas e os adesivos dentinários são os que mais se modificam e evoluem numa 
rapidez que surpreende e suas aplicações em diferentes substratos como o esmalte, dentina, cemento e amálgama deve ser acompanhada com extremo critério.

A expectativa de vida útil de uma restauração de resina composta, tanto quanto de outros materiais, é difícil de se determinar ${ }^{170}$.

Em abono da verdade, pode-se dizer que algumas propriedades deficientes das resinas compostas persistem, apesar do avanço verificado na tecnologia dos materiais dentários e das inovações que cotidianamente acontecem. É necessário que estudos e pesquisas mais aprofundadas se façam, relacionadas com essas propriedades e de novos indicadores que complementem as informações que hoje se conhecem.

A história da resina composta está inconclusa e no limiar do século XXI, muitas mudanças na formulação da mesma têm propiciado grandes avanços com a consequente melhoria em suas qualidades.

Não obstante, muito trabalho, estudo e dedicação será exigido dos pesquisadores para a obtenção de resinas compostas que realmente satisfaçam os usuários em todos os quesitos.

Os caminhos para serem percorridos para que isso ocorra são, ainda, muito árduos. São inúmeras as indústrias que se preocupam para que esse desiderato seja alcançado. Essas indústrias contam com aparatos tecnológicos de última geração e para as investigações possuem enormes suportes financeiros. Além do investimento financeiro, terão que dedicar muitos esforços para conseguir um produto que possa ser considerado um paradigma. São muitas e fastidiosas as frentes de trabalho para que isso ocorra. Os estrategistas de mercado, sempre que um produto novo é obtido numa indústria, no afã de conseguir um retorno rentável, alardeiam as qualidades e conseguem, muitas vezes, induzir 
coletivamente a classe a acreditar nos resultados mirabolantes prometidos.

As propriedades deficientes que mais preocupam e que são conhecidas de sobejo, podem ser enumeradas facilmente, tais como: a estabilidade da cor, a contração de polimerização, resistência ao desgaste, manuseio, escultura, acabamento e polimento.

Com relação à estabilidade de cor é necessário que os usuários da resina composta tenham consciência de que, mesmo executando a restauração com o maior esmero e cuidado extremo, esse item poderá, em pouco tempo, ser o vilão do trabalho. Sabese que é um ponto significativamente crítico e que por mais proficiência que se atribua ao profissional, a qualidade do trabalho poderá, dentro de um pequeno interregno, ser prejudicado e aflorar bem visível a instabilidade da cor.

É errado supor que as resinas compostas modernas tenham sanado essa deficiência. Não há ninguém afeito ao uso das resinas que não tenha sentido ao longo dos anos essa indesejável propriedade negativa.

Carece, portanto, de inovações, maiores investimentos tecnológicos e conhecimentos das propriedades dos materiais que entram nas composições das resinas compostas, modificando-as, para erradicar de vez essa deficiência.

Nada melhor de que a livre concorrência entre as empresas do setor, redobrando os esforços, para incentivar o aperfeiçoamento, com o fim de conscientizarse da importância da estabilidade da cor, desse material restaurador, mesmo depois de longos anos de vida útil na cavidade bucal.

Convém que se consigne aqui, a bem da verdade, que os avanços tecnológicos nos sistemas adesivos foram surpreendentes em tão pouco tempo e se não 
propiciam um vedamento marginal perfeito, constituem-se em valioso auxiliar na adesão. Desde o início, com o uso das denominadas resinas fluidas que possuíam atuação somente sobre o esmalte condicionado, até os modernos sistemas adesivos de um só frasco, a melhoria foi gigantesca.

Entrando em outro detalhe importante das resinas compostas que é o relacionado com a contração de polimerização, que todas apresentam em maior ou menor grau, não se deve esquecer que o assunto vem merecendo a mais escrupulosa atenção dos investigadores, que redobraram esforços para oferecer novos produtos. Por outro lado, técnicas inovadoras estão sendo adotadas, numa marcha progressiva, para minimizar essa contração. Equivale dizer, sanado mais este problema, terá sido dado outro grande passo para o aperfeiçoamento das resinas compostas.

Entre os grandes avanços que ocorreram com as resinas compostas, não se pode deixar de mencionar o relativo à resistência ao desgaste. Foram grandes as inovações introduzidas com o intuito de amenizar essa grande, senão a maior, deficiência, no sentido de torná-las menos desgastáveis pelo atrito. Componentes de carga foram incorporados em maior porcentagem propiciando uma prodigiosa dureza superando, em muito, as resinas predecessoras.

Pode-se assegurar, fora de dúvida, que esse considerável avanço ainda não esgotou, suficientemente, o item resistência ao desgaste, pois ele tem um valor muito grande no conjunto das qualidades das resinas compostas.

As inovações introduzidas ao longo dos anos melhoraram, significativamente, a manipulação das resinas compostas, embora muitas delas apresentem, ainda, dificuldades no manuseio, inserção ou condensação. 
Também não se deve esquecer de fazer referência ao acabamento e polimento das resinas, que numa análise criteriosa, não são suscetíveis de recebê-los convenientemente. Ao mesmo tempo são insubsistentes esses procedimentos nos dentes anteriores, com o decorrer dos anos, apesar do advento das microparticuladas. Idêntica assertiva aplica-se aos posteriores restaurados com resinas compostas, mormente com a introdução das condensáveis, cuja porcentagem maior de partículas de cargas, impossibilita um polimento ideal.

Essas considerações, embora pareça uma crítica execrável ou censura ao uso das resinas compostas, está longe de ser verdade, pois a intenção foi a de mostrar que, não obstante elas apresentem essas imperfeições, é um material que teve, triunfalmente, uma ascensão vertiginosa dentre os materiais restauradores e a odontologia moderna não pode prescindir delas.

Lembrando dessas deficiências do produto é necessário que uma atenção redobrada seja seguida pelo clínico, no sentido de compensá-las, confeccionando preparos cavitários adequados, com técnicas apuradas, com uso de instrumental apropriado e seguindo as indicações do fabricante. Não se deve introduzir novas imperfeições ao material, como manipulações, inserções e usos incorretos dos adesivos e da própria resina e reconhecer que se deve tomar cuidados especiais para não agregar defeitos, procurando impor critérios para demandar o máximo de perfeição em todos os passos para minimizar as deficiências enumeradas.

No entanto, por imperfeições que ainda sejam observadas nas resinas compostas e por mais que necessite de novos aperfeiçoamentos para tornar-se um material ideal, deve-se depositar a maior confiança de que, num futuro muito próximo, elas 
venham a consolidar-se como um dos melhores restauradores dentais superando todos os defeitos atuais.

Às vésperas de um novo milênio, em que ambiciosos projetos da humanidade estão em andamento, com a possibilidade de, em poucos anos, tornar-se realidade as viagens interplanetárias, alcançando lugares hoje inatingíveis é de se esperar que no campo das pesquisas com as resinas compostas, também notáveis inovações aconteçam e que efetivamente se concretize o papel que se almejou em seu nascimento.

Assim, este trabalho foi idealizado com o intuito de analisar comparativamente, passo a passo, o comportamento clínico de duas resinas compostas, sendo uma com maior tempo de emprego clínico e outra recentemente lançada no mercado odontológico, em condições clínicas bem controladas, por um período de dois anos, com a intenção plena de trazer mais uma contribuição para o campo das pesquisas clínicas. 


\section{REVISÃO DE LITERATURA}




\section{REVISÃO DE LITERATURA}

Uma pesquisa foi realizada por PAFFENBARGER ${ }^{129}$, em 1940, para verificar se os resultados clínicos estavam de acordo com as observações laboratoriais dos pesquisadores da American Dental Association e do National Bureau of Standards. Participaram 115 Cirurgiões-Dentistas que responderam a um questionário e fizeram uma série de 14 experimentos com várias marcas de cimento de silicato. Amostras uniformes de cada produto foram fornecidas pela Comissão de Pesquisa. Os resultados desses experimentos revelaram: (1) o comportamento físico e químico das diferentes marcas dos cimentos; (2) o efeito do método de manipulação sobre a utilidade dos cimentos. Por meio desses questionamentos ficou-se sabendo quais cimentos eram preferidos, quais propriedades os Cirurgiões-Dentistas consideravam significante do ponto de vista clínico e quais procedimentos de manipulação eles estavam usando. Isso tudo era muito importante para se preparar uma especificação para o cimento de silicato. Paffenbarger pode ser considerado pioneiro no campo das pesquisas clínicas por ter trabalhado com "inlay" de ouro, em 1932, com investigação de cimentos de fosfato de zinco, em 1935 e, ainda, com este estudo (1940) no controle das condições de confecção das restaurações de cimento de silicato.

Em 1969, BOYDE; KNIGHT $^{19}$ relataram que a grande profundidade de foco do microscópio eletrônico de varredura, combinado com sua capacidade de examinar espécimes bastante grandes por todos os ângulos possíveis, torna este método de 
microscopia muito atrativo considerando o estudo do controle de qualidade em procedimentos clínicos diretos, principalmente com respeito a restaurações conservadoras. Obviamente, dentes não podem, ser examinados "in situ" na boca, mas procedimentos clínicos podem ser realizados nos dentes que serão posteriormente extraídos, sendo possível com o MEV verificar eventuais alterações, permitindo superar as dificuldades encontradas na prática. A história da adaptação marginal, por exemplo, poderá para o futuro ser acompanhada, possibilitando verificar como ela muda com o tempo. Para esse fim, será necessário usar a técnica da réplica para a microscopia eletrônica de varredura, que apresentará vantagens sobre o uso da microscopia ótica ou da microscopia eletrônica de transmissão porque permitirá examinar a superfície completa da réplica e mantê-la inteira em foco. A expansão do uso da microscopia eletrônica de varredura no exame dos problemas clínicos dentais poderá ser limitada, principalmente pelo custo do processamento.

McLEAN; SHORT ${ }^{111}$, em 1969, estudaram 3 tipos de resina composta. Grupo 1 - polímero acrílico/compósito com partícula inorgânica (TB 71 resina experimental reforçada); grupo 2 - resina líquida/ compósito com partícula inorgânica (P Cadurit e Addent 35); grupo 3 - polímero - compósito cerâmico coberto (TD 71). Para avaliar as restaurações utilizaram os critérios sugeridos por Hedegard, B. (Acta odont.Scand., v.13, Suppl., p.17, 1955) que descreveu métodos de avaliação da vida clínica das restaurações plásticas e de silicato. Sua publicação reporta estudos visuais e microscópicos e classificou seus resultados com os seguintes códigos: bom - nenhuma objeção pode ser feita da adaptação; regular - precisão marginal clinicamente aceitável, mas há traços de manchamento notável nas margens da restauração; insatisfatório - descoloração distinta na margem, a qual pode ser claramente percebida com uma exploração; ruim - descoloração severa nas margens da cavidade, uma sonda afiada prenderá na interface dente/restauração. As duas primeiras 
condições permitem ao operador julgar uma restauração clinicamente aceitável, não havendo a necessidade de substituição. Usaram também os 5 critérios de Ryge (Ryge, G.; Snyder, M.A. ; Morgan, S.C. Paper read before F.D.I. Congress, 1966), para avaliar as restaurações de classe III e V. Os critérios selecionados foram: cor, descoloração marginal, forma anatômica, integridade marginal e descoloração profunda produzida por cárie secundária, infiltração severa ou ruptura da interface resina-carga. Estes critérios foram desenvolvidos num sistema de medida baseada na aplicação sistemática de uma série de julgamentos subjetivos e testes objetivos simples. As restaurações de classe III e V com os materiais citados foram examinados aos 2 anos (Addent 35), 3 e 7 anos. Restaurações com cimento de silicato foram usadas como controle. Os resultados mostraram que com as restaurações de resina experimental reforçada com vidro, o vedamento marginal e a resistência à percolação de flúidos foram altos. A resistência à abrasão requer melhorias antes do material ser considerado clinicamente aceitável.

Uma pesquisa clínica com uma resina composta experimental (TD71-Dental Fillings LTD.) com a participação de 77 operadores de escolas de odontologia, da prática privada e industrial foi conduzida por FRIEND; JACOBSEN; BEAL ${ }^{64}$ em 1970. A avaliação durou 7 meses para ser completada ( 3 meses para organizar a pesquisa, 2 meses para a parte clínica e os 2 meses subsequentes para análise e apresentação dos resultados para publicação). Foi estipulada uma seqüência de trabalho, onde classes III e V foram feitas pelos operadores seguindo a metodologia previamente fornecida. As características de manipulação do material foram investigadas e iam sendo anotadas em uma ficha apropriada. Analisaram cor, mistura, consistência, aderência aos instrumentos, facilidade de inserção, tempo de trabalho, velocidade de endurecimento, acabamento da restauração, resultado alcançado com o material e comparação com outros materiais restauradores. O material comportou-se bem e 
um número de fatos interessantes foram descobertos, principalmente com relação à mistura, tempo de trabalho e tempo de endurecimento.

Em 1970, uma pesquisa com a resina composta Adaptic foi feita por RIBBONS ${ }^{140}$, quando mais de 200 restaurações foram confeccionadas. Cinquenta e seis delas foram reexaminadas 4 semanas após a inserção e a condição de mais 79 é relatada. As restaurações foram checadas entre 6 e 24 meses após a inserção, sendo que a maioria $(81,3 \%)$ foi examinada acima de 12 meses da data da inserção. Todos os profissionais que participaram eram membros do corpo docente da Faculdade de Odontologia do Hospital Universitário. Alguns eram clínicos gerais, tanto quanto os membros do quadro do hospital e avaliaram aquelas restaurações que foram inseridas em suas próprias clínicas. As restaurações executadas, originalmente, no Hospital Universitário foram checadas por um dos autores. Foram avaliadas cor, textura de superfície, forma anatômica e se um contato satisfatório com o dente adjacente estava sendo mantido. As bordas foram examinadas com uma sonda afiada e a relação com o dente vizinho foi observada. Após cada restauração ter sido avaliada, um questionário foi respondido. Foram feitas restaurações de classe I, II, III (a maioria), IV e V. Trinta e três restaurações $(41,7 \%)$ não prenderam a sonda no teste da adaptação marginal, 17 exibiram leve preensão e o restante foi classificada como satisfatória. Na textura de superfície e cor, 33 restaurações eram ásperas e, dessas, 5 já tinham superfície áspera quando inseridas; 46 foram classificadas como lisas. Onze $(13,9 \%)$ escureceram levemente; 3 mostraram mudança de cor somente na margem gengival, mas não requeria substituição. Somente 5 restaurações tiveram o seu contorno alterado. Quando a resina composta Adaptic sofreu alguma modificação na sua composição, RIBBONS; PEARSON ${ }^{141}$, em 1973, fizeram outro trabalho de pesquisa. Os operadores eram os mesmos do trabalho anterior, que após a confecção da restauração, responderam a um questionário. Noventa e quatro restaurações 
foram observadas e como na primeira pesquisa, a maioria era de classe III. No trabalho original, $81 \%$ das restaurações mostraram cor aceitável. Após vários meses trabalhando com a resina e acrescentando pigmentos na segunda pesquisa, esperava-se uma melhora nos resultados. Na verdade, isso não ocorreu e a proporção das restaurações que eram julgadas boas na cor caiu para $78 \%$.

LIATUKAS $^{103}$, em 1972, se propôs a fazer uma investigação clínica de 4 anos, para avaliar várias resinas compostas usadas para restaurar dentes anteriores cariados ou fraturados. O estudo envolveu 234 cavidades de classe III, IV, V, alguns dentes fraturados e pacientes com idades que variavam de 10 a 60 anos. Os materiais usados foram Adaptic, Addent-Concise e Epoxylite, os quais foram manipulados conforme orientação dos fabricantes. As cavidades de classe III e V foram preparadas de maneira convencional e nas de classe IV ou nos dentes fraturados foram colocados pinos. As restaurações foram avaliadas a cada 6 meses quando possível. Fotografias foram feitas nos intervalos de 1 ou 2 anos. Os critérios para avaliação foram: fratura, descoloração, adaptação marginal, reação pulpar, resistência ao atrito e ao desgaste, tolerância tecidual e cárie recorrente. Onde os dentes ocluíam com dentes antagonistas, abrasão e desgaste foram observados após 6 meses. Descoloração, em graus variados, foi notada em todas as restaurações. Quanto à adaptação marginal, variou com as diferentes resinas compostas. Algumas restaurações mostraram leve abertura. Outras exibiram alguma depressão ao redor das margens. Nenhuma restauração se fraturou, mesmo as mais extensas. A necrose pulpar ocorreu em 13 dentes, dos quais 4 não tinham ou apresentavam muito pouca proteção. A tolerância tecidual foi boa, a recorrência de cárie foi observada apenas em pacientes com má higiene oral.

Quarenta e seis pares de restaurações de classe III e V foram feitas 
em pacientes adultos por CHANDLER et al. ${ }^{34}$, em 1973. Uma de cada par foi restaurada com uma resina composta experimental, a outra foi restaurada com Addent 35, um material disponível comercialmente no período da confecção das restaurações (1968-1969). As restaurações foram avaliadas por 3 Cirurgiões-Dentistas em $0 ; 1 ; 2,5$ e 3,5 anos com base na sensibilidade, fratura grosseira, queda da restauração, cáries secundárias, necessidade de substituição, cor, textura superficial, manchamento superficial, fenda marginal, manchamento marginal, excesso marginal e se a restauração era melhor, pior ou igual ao seu par. Os resultados indicaram que não houve diferenças essenciais entre os dois materiais com relação a sensibilidade, fratura grosseira, perda de restaurações, cáries secundárias, necessidade de substituição, manchamento superficial e excesso marginal. Houve uma leve vantagem do material experimental com respeito à alteração de cor, textura superficial, fenda marginal e manchamento marginal. Um número significantemente maior de restaurações feitas com material experimental foi considerado como melhor que o das restaurações feitas com Addent 35.

O desenvolvimento e introdução de um novo método para classificação da qualidade das restaurações foi testado como experimento, em 1973, por RYGE; SNYDER ${ }^{148}$. Foram utilizadas 2 classificações, satisfatória ou não aceitável; sendo que dentro da satisfatória, 2 subclassificações eram possíveis de serem usadas dependendo do estado da restauração: "está de acordo com os padrões" e "observe na próxima visita". Para a não aceitável, as subclassificações eram: "substituir por prevenção" e "necessidade de substituição". Um critério específico com códigos que correspondiam à cada uma das 4 categorias, levando em consideração 3 características: a superfície e a cor, forma anatômica e integridade marginal. Dois Cirurgiões-Dentistas realizaram trabalhos onde examinaram 991 restaurações e reexaminaram 109 dessas restaurações a fim de checar a concordância do 
examinador com ele próprio. Aproximadamente $98 \%$ das restaurações foram classificadas como "satisfatórias", sendo $62 \%$ dentro da categoria "está de acordo com os padrões". Se a restauração não estivesse de acordo com os padrões, a razão era incluída na avaliação. No campo de testes do sistema, os 2 examinadores concordaram na classificação final em $92 \%$ e a concordância do examinador com ele mesmo foi de $89 \%$ no reexame de uma amostragem de $10 \%$ das restaurações avaliadas.

FONTANA et al. ${ }^{63}$, em 1974, fizeram um estudo, documentado em publicação como sento parte I, procurando estabelecer a relação entre os dados obtidos pelas pesquisas de laboratório e o desempenho clínico de alguns materiais restauradores. Os períodos de observação foram: básico, 6, 9, 12, 15, 18 e 21 meses. Foram selecionados 75 pacientes entre alunos de graduação da Faculdade de Farmácia e Odontologia de Araraquara. Em cada paciente foi colocado um par de restaurações, de classe III ou V, usando vários materiais. Três docentes da Disciplina de Dentística realizaram as restaurações e as avaliações. Avaliaram o contorno ou perda de material e a descoloração marginal das restaurações. O critério de avaliação foi o de Ryge. Concluíram que o tempo condicionou alterações significativas para todas as propriedades e esse efeito foi muito mais acentuado nos primeiros 6 meses.

DINELLI et al. $^{48}$, em 1974, em continuidade ao trabalho de FONTANA et al. $^{63}$ (parte I) sobre a avaliação clínica com materiais estéticos, à qual denominaram parte II, deram enfoque para a integridade marginal, utilizando o método de Ryge. Depois de avaliarem os dados obtidos de 3 em 3 meses, durante toda a experimentação, puderam concluir que a integridade das margens das restaurações mostrou comportamento clínico diferente para os materiais estudados. A tendência de deterioração marginal, em 
função do tempo, ficou caracterizada e esta perda foi mais severa nos primeiros exames. Essas alterações foram mais evidentes nos primeiros 6 meses, sendo menos acentuadas nos tempos subsequentes. As propriedades estudadas sofreram constantes alterações em função do tempo, porém de modo menos acentuado à medida que o tempo aumentava. Para essas alterações apenas transpareceu diferença estatística quando os tempos foram considerado de 6 em 6 meses.

Complementando as partes I e II, já citadas, GABRIELLI et al. ${ }^{65}$, em 1975, deram sequiência às publicações dos resultados do trabalho de pesquisa, procurando definir o significado clínico estabelecido nas mais rigorosas condições laboratoriais, realizando uma série de restaurações em dentes anteriores, com vários materiais restauradores. Avaliaram de 3 em 3 meses, durante toda a experimentação (21 meses), a recidiva de cárie e a descombinação em cor, seguindo normas que tornavam o sistema de avaliação mais simples e menos subjetivo. Os resultados foram submetidos à análise estatística apropriada, os quais sugeriram que as propriedades estudadas apresentaram o mesmo comportamento clínico para todos os materiais, sendo que o tempo condicionou alterações significativamente diferentes para a descombinação de cor, tornando-se mais evidentes à medida que aumentava, embora a recidiva de cárie não sofresse esse efeito.

Em 1975, JACOBSEN ${ }^{81}$, após estudar os aspectos clínicos de materiais restauradores a base de compósitos, concluiu que as resinas compostas, como todos os materiais restauradores, são vulneráveis à técnica pobre e ao uso incorreto. Os maiores problemas são a contração de polimerização, o alto coeficiente de expansão térmica e a pobre resistência à abrasão da matriz resinosa. A técnica do ataque ácido proporciona aumento da retenção e vedamento, mas seu uso deveria estar restrito a áreas onde há uma indicação 
clínica distinta. O futuro dos materiais restauradores estéticos recai no desenvolvimento de monômeros de baixa contração e o ganho de adesão química.

Uma avaliação clínica de 4 resinas compostas foi conduzida por LEINFELDER et al. ${ }^{102}$, em 1975, num período de 2 anos. Quatro membros do Departamento de Odontologia Restauradora realizaram preparos cavitários de classes I, II, III e V e avaliaram segundo os critérios desenvolvidos por Cvar; Ryge. Os 4 clínicos foram treinados como avaliadores e intermitentemente testados durante o transcorrer do estudo para consenso e concordância. As avaliações foram baseadas no julgamento de 2 examinadores. A maioria dos pacientes eram estudantes de Odontologia do $1^{\underline{0}}$ e $2^{\underline{0}}$ anos escolhidos para facilitar os retornos. Os preparos cavitários de classe $\mathrm{V}$ foram feitos em dentes anteriores tanto quanto em posteriores. Os de classe I, em molares e premolares. Os de classe II, entretanto, foram limitados aos premolares, onde apenas 2 superfícies estavam envolvidas. Os de classe III foram feitos em todos os dentes anteriores exceto na distal dos caninos. As 4 resinas compostas e a resina controle foram avaliadas pela cor, desgaste, adaptação marginal, descoloração marginal e cárie secundária. O amálgama, material controle, foi avaliado por desgaste e adaptação marginal. Os tempos de observação incluíram 1 semana, 3, 6, 12 e 24 meses. Um total de 899 restaurações foram colocadas. O consenso entre os avaliadores foi de $85 \%$ ou mais. Ao final de 2 anos, 4 restaurações posteriores de resinas compostas estavam tão gastas que expuseram a dentina, porém as resinas compostas demonstraram maior resistência ao desgaste que a resina acrílica sem carga usada como controle. Apesar das restaurações de resina composta exibirem apreciável desgaste quando submetidas a altas cargas mastigatórias, essas geralmente revelaram boa adaptação marginal e resistência a manchamento marginal. Nenhuma das 668 restaurações de resina composta incluídas nesse estudo exibiu evidência clínica de cárie secundária. 
SMALES $^{159}$, em 1975, examinou e avaliou 4 resinas compostas, em dentes permanentes anteriores, por 3 anos. Participaram desse estudo 69 pacientes voluntários. Cirurgiões-Dentistas do Hospital Real de Adelaide (Austrália), alunos de graduação e pós-graduação fizeram as 269 restaurações. Foram realizadas 308 observações de restaurações separadas. Embora houvesse diferenças significantes ocasionais entre os 4 materiais, o autor pode concluir que estes apresentavam-se inadequados, quando comparados com a estrutura dentária; poucas restaurações apresentaram superfícies lisas, boa combinação de cor, condição gengival satisfatória ou estavam livres de placa; muitas restaurações tiveram discrepâncias marginais e manchamento, sendo essas últimas parcialmente relacionadas com o hábito assíduo de fumar; poucas restaurações mostraram desgaste incisal, fraturas de corpo, manchamento e desintegração superficial, desintegração marginal ou reincidência de cárie. A maioria dos defeitos tornou-se aparente com o passar do tempo.

Duas resinas compostas foram avaliadas por SMALES ${ }^{160}$, em 1977. Foram realizadas 407 restaurações de classe III, 55 de classe IV e 75 de classe V, totalizando 537 restaurações. Um grupo heterogêneo de profissionais (Cirurgiões-Dentistas do hospital, alunos de graduação e pós-graduação) inseriram as restaurações, muitas sob isolamento absoluto, mas nem todas. Os pacientes tinham idades entre 11 a mais de 61 anos. As restaurações foram feitas em dentes anteriores, sendo $83 \%$ em dentes anteriores superiores e avaliadas por um período de 5 anos. Quando os preparos eram profundos recebiam proteção com pasta de hidróxido de cálcio. Poucas restaurações tiveram superfícies lisas e boa combinação de cor, produziram condição gengival satisfatória ou estavam livres de placa; muitas restaurações tiveram pequenas fraturas marginais ou manchamento. Restaurações insatisfatórias estavam associadas a gengivites e má-higiene oral, alta incidência de cárie, excesso de fumo e desgaste por próteses removíveis. 
Em 1977, STANFORD; RYGE ${ }^{176}$, juntamente com o grupo de trabalho da Comissão em Materiais Dentários, Instrumentos e Equipamentos, e Terapêutica, descreveram uma seqüência de ítens que devem ser levados em conta na elaboração de um protocolo de pesquisa clínica, na verdade um esboço ou perfil de um protocolo de pesquisa, que são: (1) o problema, o que será estudado; (2) objetivos ou hipóteses; (3) dados e informações requeridas para cumprir os objetivos; (4) população a ser estudada, quais as unidades e como essa população será selecionada; (5) procedimentos experimentais, o plano operacional, os métodos e as circunstâncias para conduzir a pesquisa; (6) métodos de coleta de dados, descrição de como os dados e informações serão obtidos e indicam quem será responsável pela obtenção desses dados; as formas que serão usadas, inclui a definição e os critérios para classificação de cada ítem dos dados a serem coletados; (7) análise dos dados, como eles serão sumarizados, o preparo das tabelas e os testes estatísticos que serão empregados; (8) publicação, descrever a forma e o estilo final da publicação, nome dos autores; (9) os pesquisadores, as facilidades, os equipamentos ou suplementos necessários, incluir o tempo estimado; (10) orçamento, o custo pessoal, dos consultores, viagens, equipamentos, provisões, impressão e quaisquer outros serviços; (11) cronograma de atividades, listar as principais fases operacionais no projeto, data da coleta dos dados, redação do trabalho e especificação do início e/ou complementação do trabalho.

Novamente em conjunto com o grupo de trabalho da Comissão em Materiais Dentários, Instrumentos e Equipamentos, e Terapêutica, STANFORD; RYGE ${ }^{177}$, em 1977, desenvolveram mais este trabalho, que na verdade, é uma complementação da publicação anterior, acima citada ("Recommended outline for a research protocol" - 1977). Nesta há uma explanação mais detalhada de cada item relatado no perfil ou esboço de um protocolo de pesquisa como parte dos esforços coordenados para desenvolver melhores 
materiais e técnicas na odontologia. Enquanto materiais dentários comumente aceitos têm sido estudados extensivamente sob condições laboratoriais, há uma necessidade clara de estudos clínicos controlados desenvolvidos para estabelecer a significância das variáveis selecionadas sob condições clínicas ou uso. Descrições sobre projetos , informações e dados requeridos, população a ser estudada, procedimento, método de coleta dos dados, planos de análise dos dados, pesquisadores, equipamentos e provisões necessários, publicação são feitos com detalhes. Como apêndice, os autores, citam um exemplo de um guia de procedimentos clínicos de 2 resinas compostas usando a técnica do condicionamento ácido (I- Materiais; IIIntrodução; III- Procedimentos gerais; IV- Avaliações; V- Cronograma). Nos anexos, encontra-se exemplos de fichas de: 1) concordância em participação do paciente; 2) procedimento de anotação de restaurações anteriores; 3) anotações sobre o lote dos materiais e qualquer possível variação nos procedimentos de pesquisa; 4) os critérios a serem estudados com suas classificações para cor, descoloração marginal, forma anatômica, adaptação marginal, cárie secundária e 5) estudos de restaurações de dentes anteriores e posteriores (ficha de anotações de escores propriamente dita).

Uma avaliação clínica de 8 resinas compostas, observando seu comportamento individualmente e com relação às outras foi feito por FLYNN ${ }^{62}$, em 1978. Cento e quarenta lesões cariosas de classe IV, de tamanho e localização similares, foram restauradas (15 restaurações por material). O material restaurador ultrapassou a margem cavosuperficial em aproximadamente 2,0 mm. Nenhuma retenção mecânica por meio de pinos, bisel ou preparo cavitário convencional foi empregada. Antes do condicionamento ácido, a estrutura dental foi limpa com pedra pomes, lavada com água e seca. Quando havia dentina exposta, esta era protegida com hidróxido de cálcio. O manuseio da resina composta foi feito por um Cirurgião-Dentista, de acordo com as recomendações dos fabricantes. 
Fotografias coloridas e moldagens foram usadas para registrar as condições do "baseline" (imediatamente após o acabamento) e comportamento pós-operatório a intervalos de 6 meses até a data da publicação deste trabalho. As moldagens foram vazadas com resina epóxica de baixa viscosidade e as réplicas foram metalizadas com ouro-paládio para observação no microscópio eletrônico de varredura. Duas categorias de falha de retenção foram estabelecidas: primária - na qual a perda ocorreu durante a mastigação normal e secundária na qual a perda ocorreu como resultado de trauma. O desgaste marginal foi avaliado pelo exame das fotomicrografias com aumentos de $7 \mathrm{X}$ e $20 \mathrm{X}$. As medidas eram limitadas aos 2/3 centrais da superfície envolvida. Um ponto de referência tal como um defeito no esmalte, uma bolha na restauração ou um contorno distinguível foi identificado em cada restauração. A margem foi medida relativa ao ponto de referência e a relação com a margem original foi calculada. Relações máximas e mínimas foram medidas para estabelecer uma variação. A cada intervalo estudado o desgaste foi classificado de acordo com a quantidade de alteração marginal: alpha, menos que $600 \mu$; beta, entre 600 e $1000 \mu$; charlie, maior que $1000 \mu$. A textura de superfície foi avaliada pelo exame das fotografias obtidas no microscópio eletrônico de varredura com aumentos de 100 X e 200 X. Três graus de rugosidade foram estabelecidos: lisa, média e áspera. As observações para cada material foi baseada no acabamento original, o qual havia recebido índice liso. Retenção: aos 6 meses, 5 restaurações foram perdidas devido a falha na retenção. Quatro perdas devido a trauma secundário (mas não foram tabuladas). As demais restaurações estavam retidas aos 24 e/ou 30 meses. O estudo de um dos materiais foi descontinuada por causa das numerosas falhas de retenção. Desgaste marginal: desgaste vestibular ao longo da margem da porção central da restauração foi consideravelmente maior que o desgaste lingual, proximal e incisal. Assim mesmo foi considerado pequeno (menos que $200 \mu$ ). Em geral, a maioria das resinas compostas 
começam a apresentar evidência de desgaste durante os primeiros 6 meses. O grau de desgaste foi maior durante os primeiros 6 meses, menor no segundo período de 6 meses e menor ainda e constante pelo resto da pesquisa. Durante o período da pesquisa, 3 restaurações foram perdidas por causa do desgaste marginal excessivo. Textura de superfície: a maioria dos materiais foi clinicamente aceitável durante o transcorrer da pesquisa. Aos 12 meses, 1 material recebeu índice liso; 4, médio e 2, áspero.

Um estudo realizado por LEINFELDER; SLUDER; SANTOS $^{101}$, em 1978, investigou o comportamento clínico de resina composta em dentes anteriores e posteriores, após 5 anos. Um total de 412 restaurações foram avaliadas usando o sistema Ryge e fotografias coloridas. As características estudadas foram: cor, cárie recorrente, manchamento interfacial, integridade marginal e desgaste. Um ou dois estágios de réplicas de restaurações selecionadas foram, também, avaliadas com microscópio eletrônico de varredura. Acima de $90 \%$ de todas as classes III e V restauradas com resina composta obtiveram o escore "bravo" (clinicamente aceitável). Uma forte correlação existiu entre tamanho da restauração e performance clínica. Quanto mais conservativa a restauração, mais alta era a porcentagem de escores "alpha" (ideal). Em geral, o comportamento clínico das resinas compostas na face vestibular e lingual dos dentes posteriores foi pelo menos tão bom quanto as classes III. Menos de $25 \%$ das restaurações de classes I e II foram consideradas clinicamente aceitáveis. Cáries secundárias aconteceram somente em duas restaurações. Baseados nos resultados desse estudo, os autores chegaram a conclusão de que a longevidade das restaurações de resina composta, em preparos cavitários conservativos de classe III e V, pode ser de 10 anos ou mais.

BOZELL; CHARBENEAU ${ }^{20}$, em 1979, determinaram se 
diferenças podiam ser observadas num período de tempo entre restaurações de composição similares de cavidades de classe III e V recebendo 3 tipos distintos de tratamento das paredes de esmalte: (1) preparação com esmalte não condicionado; (2) paredes de esmalte condicionadas; (3) paredes de esmalte condicionadas e cobertas com o agente de união do Adaptic. A resina composta Adaptic foi usada em todos os casos. Cada tratamento foi empregado na mesma boca para que comparações diretas pudessem ser feitas dentro de um ambiente similar. $\mathrm{O}$ método de tratamento foi designado para os dentes aleatoriamente. $\mathrm{O}$ critério do "Dental Health Center" para cor, descoloração marginal, integridade marginal, forma anatômica e cárie foi empregado usando avaliação independente feita por 2 examinadores. Ao final de 24 meses metade da população observada não mostrou mudanças desde o "baseline" em cor, forma anatômica ou cárie. Descoloração marginal foi observada em $44 \%$ das restaurações não condicionadas, $31 \%$ das condicionadas e $19 \%$ das condicionadas e com agente de união. A falta de adaptação marginal foi observada em $25 \%$ das restaurações não condicionadas, $19 \%$ das condicionadas e $12 \%$ das condicionadas e com agente de união.

Em 1979, BRYANT; REES; ROSS ${ }^{26}$ avaliaram clinicamente um material estético na forma de duas pastas (Isopast - Ivoclar/Vivadent). Um total de 192 classes III e $\mathrm{V}$ foram avaliadas por 2 Cirurgiões-Dentistas em diferentes tempos após a inserção quanto à adaptação marginal, forma antômica, cor e descoloração marginal. Cinquenta e duas restaurações foram primeiramente observadas após 6 a 8 meses, 73 após 9 a 11 meses e 67 após no mínimo 1 ano. A maioria das restaurações avaliadas eram de classe III. Quando as restaurações foram feitas aproximadamente $95 \%$ da avaliação inicial dos critérios citados foram classificados como "A" (Alfa), o restante "B" (Bravo). Das restaurações reavaliadas 14 não mostraram mudanças da classificação inicial, ao passo que, 51 mostraram 
alguma modificação. Cinco restaurações necessitaram substituição: uma parecia ter sido polimerizada incompletamente e mostrou mudança em todos os critérios; uma restauração foi perdida; 2 restaurações grandes de classe III precisaram ser substituídas após a fratura do ângulo incisal do dente. Uma das 46 restaurações que mostraram alguma mudança, foram anotadas 60 alterações; algumas mostraram 2 ou mais tipos de alterações. A mudança mais frequentemente anotada foi cor e descoloração marginal. Além das anotações feitas na primeira reavaliação, 27 das 192 restaurações foram reavaliadas uma segunda vez. Vinte não mostraram alterações quando comparadas com a primeira reavaliação, 1 restauração apresentou problemas na forma anatômica em ambas as reavaliações.

O manchamento das margens e a rugosidade da superfície foram relatadas por RUPP ${ }^{145}$, em 1979, como sendo as queixas mais frequentes registradas contra as resinas compostas. O manchamento marginal tem muitas causas tais como: (1) fratura do esmalte durante o preparo da cavidade, (2) contração de polimerização excessiva da resina composta, (3) manipulação muito lenta, o que permite uma perda da plasticidade durante a inserção, (4) pressão inadequada de manutenção durante a polimerização da resina e (5) uso de instrumentos de acabamento, os quais causam defeitos nas margens dos dentes e/ou da resina composta. Esses defeitos o operador pode controlar, caso contrário, eles ficarão incorporados na restauração. A rugosidade das resinas compostas pode ser reduzida pelo polimento com a granulação mais fina disponível em discos. As restaurações atuais, de resinas compostas, feitas com cuidado irão proporcionar restaurações estéticas de longa duração, contanto que não sejam colocadas em áreas sujeitas a estresses.

Por meio de técnica de replicação da superfície das restaurações para exame no MEV e para medir a quantidade de material perdido dessa superfície, TAY et 
al. ${ }^{182}$, em 1979, usaram 4 materiais restauradores estéticos, disponíveis na época, e os avaliaram clinicamente, em 8 pacientes, o "baseline" desses materiais e após 3 anos. Avaliaram a área próxima à margem da restauração e do dente dividindo-a em 3 regiões. Região A: superfície periférica da restauração bem próxima à margem, mas sem incluir nenhum defeito na margem, que era analisado em outra categoria. Essa região era descrita em termos do contorno da restauração relativa ao dente vizinho, como tendo excesso ou falta. Região B: correspondia à margem da restauração e era referida como sendo topo a topo, em excesso sobre o dente ou com falta em forma de sulco. Região C: estava topo a topo com a restauração ou sobre a restauração ou em bisel. A extensão de cada região era medida em cada restauração e expressa em porcentagem do total da margem. Os valores médios para as categorias eram anotados para cada material. A perda superficial foi também medida, sendo as posições onde elas ocorriam determinadas por comparações de séries de fotografias das restaurações, feitas sob microscopia eletrônica de varredura. Réplicas das restaurações, no "baseline" e após 3 anos, foram seccionadas em ângulo reto com a margem e através do centro da restauração. As secções eram cortadas com lâminas de bisturi e fotografadas ao microscópio com aumento de 13 vezes. Eram feitos traçados dos perfis do início do trabalho e de 3 anos e, por meio de superposição, eram observadas e medidas as discrepâncias. Durante o período de avaliação, 4 pacientes não retornaram, assim 8 pacientes com 39 restaurações permaneceram. Um silicato experimental comportou-se melhor que o convencional e ambos perderam menor quantidade de material da superfície que as resinas. A resina convencional comportou-se melhor que a resina composta. Os autores ainda relatam que a classificação das restaurações tendeu a subestimar a perda superficial das restaurações com superfícies lisas e portanto recomendaram a combinação do método de classificação com o método de medida de perda de substância. Evidenciaram a importância de comparações dos materiais no mesmo 
paciente.

Em 1980, ERIKSEN ${ }^{55}$ enfatizou a importância de métodos fidedignos para avaliação clínica de restaurações. O "Sistema Ryge” é provavelmente o mais conhecido método para avaliação clínica direta de restaurações (Stanford; Ryge - 1977). Para materiais estéticos os seguintes fatores são incluídos: cor, descoloração marginal, forma anatômica, adaptação marginal e cárie recorrente. O "Sistema Ryge" é perfeitamente adequado, também, para estudos de durabilidade das restaurações, com as principais razões para se substituí-las. O autor cita o trabalho de MJÖR ${ }^{115}$ apud ERIKSEN ${ }^{55}$ que conduziu um estudo entre Cirurgiões-Dentistas suecos. Durante um período de 2 semanas, eles listaram as principais indicações para todas as restaurações feitas de acordo com o "Sistema Ryge". Mais de $80 \%$ de um total de 1100 restaurações estéticas feitas, já eram substituições das também insatisfatórias restaurações com cimento de silicato ou com resinas compostas. Isto indica que qualidade inferior é responsável pela maioria do tempo, esforço e dinheiro gastos neste campo, pelo menos na Escandinávia. Uma análise detalhada dos dados mostrou que falhas na integridade marginal foi o fator dominante para substituição das restaurações de resina composta (cerca de 30\%) seguida de cárie recorrente (20\%) e descoloração generalizada alteração de cor (15\%), descoloração marginal e forma anatômica alcançaram aproximadamente 5\% cada. Além disso, discutiu várias técnicas indiretas de avaliação clínica e sua eficácia comparadas com a técnica direta similar disponível para se estudar resina composta. Para adaptação marginal (integridade), a mais comum é a análise em microscópio eletrônico de varredura das réplicas da situação in vivo. Fotografias clínicas também são usadas para amálgama. Para cárie recorrente, devido à uma radiopacidade não adequada da maioria das resinas compostas, o diagnóstico radiológico é duvidoso. Então, o critério é melhor avaliado pela inspeção clínica direta. Considera-se fotografias clínicas um método 
efetivo para o registro da mudança de cor. Pode ser usado em conjunto com a avaliação clínica direta. Para rugosidade de superfície, pode ser usada a sondagem comparando com placas de vidro de rugosidade crescente. Métodos clínicos indiretos usando profilômetro em modelos feitos a partir de moldagens das restaurações também são usados. Para descoloração marginal pode ser avaliada pela inspeção visual direta e classificada de acordo com a severidade. Fotografias clínicas também podem auxiliar. Para desgaste oclusal, que não está entre as principais razões para se substituir restaurações com resina composta, pode ser observado pelos registros clínicos indiretos por meio de moldagens.

$\mathrm{RYGE}^{146}$, em 1980, estabeleceu um caminho sistemático para avaliação clínica de materiais restauradores propondo uma série de questões, às quais uma resposta "sim" ou "não" pode ser dada. Este sistema fornece condições para alcançar decisões na adaptação marginal, restauração ou preservação da forma anatômica, proteção contra cárie recorrente e no caso dos materiais usados em restaurações anteriores, cor e descoloração marginal. Usando esses critérios, as restaurações podem ser classificadas em 4 categorias: aquelas dentro de uma variação de excelência; aquelas que, embora mostrando desvios menores do ideal são, contudo, aceitáveis; aquelas que deveriam ser substituídas por razões preventivas para evitar a probabilidade de futuros danos e aquelas que requerem substituição imediata. Os 5 critérios discutidos, no presente, representam aqueles incluídos no protocolo para programas de pesquisa clínica recomendado pela FDI. Apresenta, ainda, algumas regras que devem ser seguidas para o exame clínico e escoreamento: 1) 2 Cirurgiões-Dentistas farão avaliações independentes; 2) cada Cirurgião-Dentista avaliará cada característica (ver critério específico de qualidade de avaliação); 3) a característica com o mais baixo escore determina a classificação; 4) se um subescoreamento é outro que não o Romeo, as abreviações que indicam o critério usado devem ser anotadas na forma da classificação; 5) se ambos os 
Cirurgiões-Dentistas concordam no subescoreamento, ele é considerado final; 6) se há um desacordo na classificação, os 2 Cirurgiões-Dentistas reexaminarão o aspecto tratado sob consideração e chegarão a uma decisão final juntos.

NAVARRO ${ }^{120}$ idealizou um trabalho com a finalidade de verificar comparativamente o comportamento clínico de um cimento de silicato (Syntrex F), uma resina acrílica (Sevriton), uma resina composta (Estilux) e um cimento ionomérico (ASPA), desde a inserção, periodicamente até 4 anos. Cento e vinte restaurações de classe III e V, 30 com cada material foram feitas em 23 pacientes. Três profissionais prepararam as cavidades e as restauraram. Os materiais foram manipulados criteriosamente. Na sessão do acabamento e polimento era feita a avaliação inicial das restaurações. Para cada conjunto de 4 restaurações distintas foi preparada uma ficha clínica que continha dados dos pacientes, a identificação do material restaurador e características da restauração, como: cor, descoloração marginal, forma anatômica e cárie. Cada item recebia um escore em 3 níveis: bom (0), aceitável (1) e inaceitável (2). Somente para o fator cárie é que havia 2 níveis: ausente (0) e presente (1). Dois avaliadores previamente calibrados fizeram as avaliações independentemente. Quando havia discordância, a avaliação era refeita em conjunto e os avaliadores chegavam a um consenso. Os critérios de avaliação adotados foram baseados nos de Cvar; Ryge, modificados, de classificação das restaurações de melhor para a pior ("ranking”clínico): 
Tabela 1 - Escores das restaurações

\begin{tabular}{|c|c|c|}
\hline Categoria & Escores & Restauração \\
\hline \multirow[t]{3}{*}{ Cor } & 0 & $\begin{array}{l}\text { a restauração combina com o dente em cor e } \\
\text { translucidez }\end{array}$ \\
\hline & 1 & $\begin{array}{l}\text { a descombinação entre a restauração e o dente } \\
\text { quanto à cor e translucidez é aceitável }\end{array}$ \\
\hline & 2 & $\begin{array}{l}\text { a descombinação entre a restauração e o dente } \\
\text { quanto à cor e translucidez é inaceitável }\end{array}$ \\
\hline \multirow[t]{3}{*}{$\begin{array}{c}\text { descoloração } \\
\text { marginal }\end{array}$} & 0 & $\begin{array}{l}\text { nenhuma descoloração nas margens entre o dente } \\
\text { e a restauração }\end{array}$ \\
\hline & 1 & $\begin{array}{l}\text { descoloração presente apenas nas margens, não } \\
\text { penetrando em direção pulpar }\end{array}$ \\
\hline & 2 & descoloração marginal e em direção pulpar \\
\hline \multirow[t]{3}{*}{$\begin{array}{c}\text { forma } \\
\text { anatômica }\end{array}$} & 0 & $\begin{array}{l}\text { a restauração está em continuidade com o dente. } \\
\text { O explorador não se retém nas margens. Não há } \\
\text { fenda nas margens }\end{array}$ \\
\hline & 1 & $\begin{array}{l}\text { o explorador é retido nas margens. Existe fenda } \\
\text { visível ou perceptível nas margens entre o dente } \\
\text { e a restauração, sem atingir dentina }\end{array}$ \\
\hline & 2 & $\begin{array}{l}\text { perda de material suficiente para expor dentina ou } \\
\text { base protetora }\end{array}$ \\
\hline \multirow[t]{2}{*}{ cárie } & 0 & ausente \\
\hline & 1 & presente \\
\hline
\end{tabular}

Fonte: NAVARRO, M. F. L. Avaliação clínica de restaurações estéticas. Bauru, 1981. 211p. Tese (Livre-Docência). Faculdade de Odontologia de Bauru, Universidade de São Paulo.

As avaliações foram feitas após 1 semana da inserção (inicial), após 4 meses, 8 meses, 12 meses, 24 meses, 36 meses e 48 meses. A autora concluiu que a restauração que apresentou resultados menos satisfatórios em termos de cor em todos os períodos de observação foi realizada com o ASPA; a melhor foi a de resina composta (Estilux). A resina acrílica (Sevriton) e o cimento de silicato (Syntrex F) inicialmente apresentaram boa tonalidade de cor, mas por motivos diversos apresentaram descombinação com o passar do tempo. A restauração que apresentou resultados menos satisfatórios em relação à forma foi a de silicato que, após o primeiro ano, começou a mostrar perda de substância; as demais também 
mostraram perda de substância após o primeiro ano, porém em menor intensidade. A restauração que apresentou maior índice de descoloração marginal foi a de resina acrílica, notado após o primeiro ano; com as demais restaurações também ocorreu descoloração após o primeiro ano, porém com menor intensidade. Praticamente não foi observada reincidência de cárie adjacente às restaurações testadas. Quando analisadas no aspecto geral, as restaurações que apresentaram melhor efeito estético no princípio foram as de Estilux e Sevriton; as que apresentaram efeito estético mais desfavorável foram as de ASPA, enquanto as de Syntrex F apresentaram um efeito intermediário; durante o período de observação deste trabalho o desempenho dessas restaurações foi distinto, pois enquanto algumas apresentaram aspectos favoráveis ou desfavoráveis em relação a um determinado fator, outras os apresentaram em relação a fatores diversos, de tal sorte que ao final de 4 anos os materiais em estudo praticamente se igualaram, apresentando um aspecto clínico que pode ser considerado bom.

Na preparação para os estudos da região nórdica do comportamento clínico de materiais restauradores, RYGE et al. ${ }^{150}$, em 1981 , selecionaram 11 clínicos da Dinamarca, Finlândia, Noruega e Suécia para participar de 2 sessões de treinamento clínico. A primeira dessas sessões consistiu de leituras da metodologia da pesquisa clínica, do conteúdo do protocolo de pesquisa e da descrição específica dos critérios a serem usados para a avaliação clínica da cor, descoloração marginal, forma anatômica, adaptação marginal e cárie secundária. Demonstrações também foram feitas dos procedimentos de avaliação clínica. Usando um sistema de rotação em ambas as sessões de treinamento, cada participante alternativamente serviu como paciente, anotador e examinador 1 e 2 . Os participantes examinaram e classificaram um grande número de restaurações independentemente em grupos de dois. Quando havia desacordo no escoreamento de uma restauração, os 2 examinadores eram requisitados para resolver a discordância juntando os exames. Os 
resultados do comportamento dos exames mostraram uma concordância total entre todos os pares de $85 \%$. Os resultados desse estudo indicam que após um pequeno curso introdutório, clínicos cientificamente não experimentados podem ser treinados a usar o sistema descrito a um nível de precisão comparativamente alto.

Segundo VIOHL ${ }^{195}$, em 1981, muitos esforços têm sido feitos para melhorar a estabilidade de cor das resinas compostas. Narrou observações importantes com relação à avaliação clínica da estabilidade de cor de resinas restauradoras. A estabilidade de cor depende da qualidade de iluminação e visibilidade. Em pesquisa clínica a precisão pode ser alcançada pelas características bem definidas, pela anotação do estado inicial e por examinadores treinados. Não existem instrumentos adequados para a determinação da cor de restaurações parcialmente escondidas e curvas. A inspeção visual apresenta resultados que caracterizam o material resinoso. Para o paciente, pequenas descolorações são freqüentemente escondidas pelos reflexos e iluminação não uniforme.

Em 1982, 100 restaurações de classe III com resina composta Isocap e 100 com Adaptic foram comparadas por CHRISTENSEN; CHRISTENSEN ${ }^{35}$, por 3 anos. Todas as restaurações no estudo foram avaliadas pelo (1)exame da microscopia eletrônica de varredura e diapositivos coloridos e (2) exame clínico visual e digital. As seguintes características clínicas foram avaliadas: cor, lisura de superfície, desgaste de superfície, manchamento de superfície, integridade marginal e descoloração marginal. Resultados dos diapositivos graduados e fotografias do microscópio eletrônico de varredura mostraram que Isocap foi estatisticamente superior ao Adaptic na lisura de superfície e desgaste. Não houve diferenças entre as 2 resinas com relação a integridade marginal, cor, descoloração marginal e manchamento de superfície. Avaliação por exame clínico visual e 
digital mostrou que Isocap foi estatisticamente superior ao Adaptic em lisura de superfície, desgaste de superfície, cor, descoloração marginal e manchamento de superfície. Diferenças estatísticas em integridade marginal entre Isocap e Adaptic não foram claramente demonstradas.

STANFORD; RYGE ${ }^{178}$, em 1982, recomendaram fatores que devem ser considerados pelos investigadores em planejar, iniciar e promulgar uma pesquisa clínica. A frase "fatores a serem considerados" implica que nem todos os fatores traçados serão utilizados em qualquer projeto e que a extensão da utilização de certos fatores individuais devem ser feitos sob medida para um projeto específico em mente. Estes fatores têm sido delineados primeiramente para auxiliar o pesquisador em planejar, iniciar e dar continuidade a um projeto de pesquisa clínica. $\mathrm{O}$ artigo trata de projetos avaliando materiais usados em: 1) dentística operatória; 2) endodontia; 3) ortodontia; 4) prótese removível e 5) prótese fixa. Em cada secção, deve ser dada atenção detalhada para: a) identificação do problema (passo inicial com a determinação do que será estudado, as hipóteses a serem testadas e/ou os objetivos a serem cumpridos na metodologia e procedimentos avaliativos.); b) informações antecedentes (assegurar-se de que todos os trabalhos prévios na área foi identificado e todo o conhecimento que sustenta o projeto está acumulado); c) materiais e métodos (participação do paciente deve ser delineada como descreve o modelo experimental e sua implementação - a seleção e exclusão dos pacientes do estudo, definindo a população participante; possíveis fontes de pacientes participantes pode incluir escolas, instituições e grupos organizados tais como bombeiros, policiais; a importância da cooperação das pessoas e organizações envolvidas com pacientes deve ser enfatizada; seleção de pacientes que possuam estabilidade geográfica e que estejam profundamente motivados a participar até que o trabalho seja completado; a compensação é outro incentivo que influencia na permanência 
dos pacientes até a conclusão; os pacientes devem ser informados dos riscos, benefícios e significância de sua participação; conhecimento do material a ser utilizado, tais como composição, propriedades, uso, manipulação, etc.; fatores que dizem respeito às características expressivas do material deveriam ser identificadas e métodos deveriam ser designados para medidas apropriadas dessas características; definição de procedimentos estatísticos que sejam adequados ao modelo experimental); d) aspectos administrativos (os recursos requisitados para a pesquisa clínica começam com o principal investigador que deve assumir a responsabilidade de todo o projeto - o investigador deve ter conhecimento tanto da ciência clínica quanto dos materiais, o investigador deve se familiarizar com os requisitos éticos e legais).

Vários métodos de avaliação clínica foram comparados por SMALES $^{162}$, em 1983, para verificar suas habilidades em diferenciar entre os vários graus de deterioração das restaurações. Cinquenta restaurações à amálgama (classe I) e 50 com resina composta (classes III, IV e V) com idade acima de 8 anos, foram examinadas por 4 métodos. Método A: observação clínica direta usando critério descritivo, subjetivo. O método foi similar ao descrito por Ryge e colaboradores. Para resinas compostas: $0=$ bom, 1 ou $2=$ adequado, 3 = insatisfatório (substituir a restauração); para amálgamas: 0 = bom, $1=$ adequado, 2 = insatisfatório (substituir). Para as resinas a classificação foi: $\underline{\text { Manchamento da }}$ superfície: 0 - nenhum manchamento, 1 - leve manchamento, 2 - manchamento óbvio, 3 manchamento severo; descoloração marginal: 0 - nenhum manchamento, 1 - leve manchamento, 2 - manchamento bem visível, 3 - manchamento severo; combinação da cor da resina com a cor dente: 0 - nenhuma diferença, 1 - leve descombinação, 2 - descombinação óbvia, 3 - diferença de cor severa; opacidade em relação ao dente: 0 - nenhuma diferença, 1 leve descombinação, 2 - descombinação óbvia, 3 - diferença de opacidade severa; desgaste 
incisal (classe IV): 0 - nenhum, 1 - leve perda de anatomia, 2 - desgaste bem visível, 3 desgaste severo; condição gengival: 0 - normal, 1 - leves mudanças na cor marginal, 2 mudanças bem visíveis na cor, 3 - grandes mudanças na gengiva inserida. Para os amálgamas: Descoloração da superfície: 0 - nenhuma, 1 - leve perda de brilho, 2 - severa perda de brilho; descoloração marginal: 0 - nenhuma, 1 - leve descoloração, 2 - severa descoloração; textura de superfície: 0 - liso como esmalte, 1 - leve preensão com sonda, 2 - áspera e porosa; fratura marginal: 0 - nenhuma, 1 - leve preensão com sonda, 2 - valamento até a junção dentina/esmalte. Método B: aplicação do mesmo critério subjetivo par diapositivos (aumento 1:1) Ektachrome $35 \mathrm{~mm}$, tirados no momento do exame. Tão próximas quanto possível, as fotografias foram tiradas de ângulos retos de oclusal, vestibular e lingual das superfícies dos dentes restaurados. Os diapositivos foram examinados sem aumento de imagens usando um negatoscópio. Método C: consistia de uma mistura dos diapositivos do método B com 2 "sets" padrões de diapositivos ampliados $(2 \mathrm{X})$. Para as resinas compostas foram usadas 4 amplitudes (0, 1, 2 e 3), para o amálgama havia 3 amplitudes (0, 1 e 2), de acordo com os critérios descritos no método A. Este método deu critério referencial mais objetivo que os métodos $\mathrm{A}$ e $\mathrm{B}$. O método $\mathrm{C}$ foi semelhante ao descrito por Mahler e colaboradores. Novamente todos os diapositivos foram examinados sem ampliação da imagem. Método D: envolveu a mistura dos mesmos diapositivos usados nos métodos B e C contra 2 "sets" padrões de diapositivos ampliados $(2 \mathrm{X})$. Entretanto, desta vez as escalas de graus do último foi consideravelmente estendida pelo aumento dos números de ampliações e/ou dos números de divisões de graus. Para cor da resina composta, havia 2 escalas de graus estendidos, 1 para cores mais claras e 1 para cores mais escuras que os dentes restaurados. Método D envolveu uma escala linear semelhante à que foi descrita por Mahler e Marantz. Para ambos os materiais, o uso de escalas de graus lineares estendidos (método D) prontamente detectou 
pequenas diferenças entre restaurações para todas as características clínicas avaliadas. Novamente, para ambos os materiais, o uso de escalas de graus (método C) ou critério descritivo (métodos A e B), os quais foram restritos a 3 ou 4 categorias somente, raramente mostrou quaisquer diferenças significantes entre as restaurações. Estabeleceu que as limitações do método foram descobertas, o uso de diapositivos ampliados ( $2 \mathrm{X}$ ) foi útil para avaliar várias características clínicas das restaurações à amálgama e com resina composta.

TIMMONS; LASWELL; ROBINSON ${ }^{183}$, em 1983, avaliaram o comportamento clínico de 8 resinas compostas durante 3 anos. Os materiais incluídos eram 3 resinas compostas convencionais (Adaptic, Profile e Prisma), 3 resinas compostas microparticuladas (Phasefill, Isopast e Silar) e 2 resinas compostas híbridas (Miradapt e Finesse). Usando 3 materiais, 174 restaurações classes III, IV e V foram realizadas em 41 pacientes. Todas as restaurações e acabamento foram padronizados a fim de que as restaurações realizadas pelos 3 operadores ficassem o mais similar possível. Foram feitas no mínimo 11 restaurações de cada material. Em cada restauração foi avaliada cor, forma anatômica, manchamento interfacial, adaptação marginal, usando o sistema de Ryge e Snyder (1973). Após 2 anos, 161 restaurações foram avaliadas. Um grande número de restaurações exibiram mudanças na cor. Discrepâncias na cor variaram de alta, 58\% (Isopast) a baixa, 29\% (Adaptic). As resinas compostas convencionais exibiram melhor estabilidade de cor que as híbridas ou as microparticuladas. Manchamento interfacial foi observado frequentemente na Isopast (37\%), Prisma (25\%) e Finesse (24\%). Aos 2 anos, as restaurações de resina composta mostraram poucas mudanças desde o "baseline" nas outras categorias avaliadas.

Em 1984, HANSEN et al. ${ }^{77}$ propuseram-se avaliar a integridade marginal de 2 resinas compostas de micropartículas, ativadas por luz, Durafill e Silux, com e 
sem aplicação prévia de uma resina de baixa viscosidade, após 15 meses. Foi usado Durafill/sem resina de baixa viscosidade, Durafill/com resina de baixa viscosidade e Silux/com resina de baixa viscosidade. O estudo incluíu 649 restaurações de classe III, classe III com extensão lingual, classe IV e classe V, feitas por 5 Cirurgiões-Dentistas. Com exceção das pequenas classes III e V, as cavidades foram restauradas com 2 ou mais incrementos de espessura de 2 - $3 \mathrm{~mm}$. As restaurações foram polidas dentro de 5 minutos após a polimerização, com lixas e discos Sof-Lex (3M) com leve e intermitente pressão. Os registros incluíam descoloração e integridade marginal. O critério para se avaliar a qualidade clínica foi baseado no sistema Ryge, porém levemente modificado como propôs Smales.

Tabela 2 - Critérios para avaliar descoloração marginal e fendas marginais

\begin{tabular}{lccc}
\hline Avaliação & escore & descoloração & fenda \\
perfeita & 0 & nenhuma & nenhuma \\
aceitável & $\begin{array}{l}\text { 1=leve alteração } \\
2=\text { maior alteração }\end{array}$ & $\begin{array}{l}\text { leve descoloração } \\
\text { descoloração óbvia }\end{array}$ & $\begin{array}{c}\text { leve preensão do explorador } \\
\text { maior preensão do explorador }\end{array}$ \\
inaceitável & 3=substituição & descoloração severa & dentina exposta \\
\hline
\end{tabular}
Fonte: HANSEN, E. K. et al. Clinical short term study of marginal integrity of resin restorations. Scand. J. dent. Res., v.92, n.4, p.374-9, 1984.

O grau 3 correspondeu à categoria "charlie" no sistema Ryge. Todas as restaurações foram avaliadas à maneira "cega", isto é, o Cirurgião-Dentista observava a qualidade das restaurações sem saber qual resina composta ele estava considerando e nem a técnica de aplicação. A freqüência de descoloração marginal e integridade marginal (formação de fendas) após 15 meses foi notavelmente reduzida em todas as classes quando uma resina de baixa viscosidade foi usada antes da aplicação do material restaurador. Parece que os melhores resultados foram encontrados em cavidade de classes III e V, onde a frequiência de descoloração marginal e formação de fenda marginal foi significantemente menor que nas classes III com extensão lingual e nas classes IV, para as 3 formas de utilização dos materiais. 
O padrão de longevidade de 3299 restaurações feitas em 200 pacientes que eram regularmente assistidos pelo Serviço Nacional de Saúde da Inglaterra, durante o período de 1967-1983 foi pesquisado por PATERSON ${ }^{130}$, em 1984. Considerava-se falha da restauração: (I) se total ou parte da restauração tivesse sido removida e/ou substituída; (II) se tratamento endodôntico tivesse sido realizado, necessitando remoção e/ou substituição da restauração; (III) se o dente tivesse sido extraído ou recebesse uma coroa. Os períodos de longevidade estimados em 50\%, para as várias categorias das restaurações, foram: restaurações à amálgama oclusais, 8 anos; restaurações à amálgama MO, DO, MOD, 7 anos; restaurações de silicato, 5 anos e meio; restaurações de resina composta, 4 anos e meio. Os tempos de vida média estimados para as restaurações à amálgama e silicato foram geralmente melhores que estudos prévios; para as de resina composta foram mais pobres. As diferenças entre o comportamento das restaurações, nesse e em estudos prévios, pode possivelmente ser devido a variações na cooperação do paciente, diagnóstico e a meticulosidade da técnica.

DOGON et al. ${ }^{49}$, em 1985, compararam o comportamento clínico de um material restaurador microparticulado ativado por luz visível (Silux - 3M) com um de 2 pastas, restaurador microparticulado quimicamente ativado, usados em dentes anteriores. Preparos convencionais foram feitos onde eram necessários e todas as preparações receberam uma base de hidróxido de cálcio. Informações pertinentes relativas aos materiais usados, cor, contorno proximal foram anotadas em forma de avaliação preparadas especialmente no momento da colocação. Neste estudo foram incluídas 583 restaurações com Silar e 878 com Silux e foram avaliadas a intervalos de 6 meses de acordo com a técnica desenvolvida pelo USPHS e as informações anotadas relativas à integridade marginal, resistência, desgaste, descoloração total, descoloração marginal, lisura superficial e sintomas. Fotografias foram tiradas na hora da colocação ("baseline") e nos retornos de 6 meses subsequentes. Após 3 
anos, 47,3\% das restaurações com resina de micropartículas quimicamente ativada foram refeitas, sendo $92,8 \%$ por causa da descoloração total. Em contraste, somente $4,8 \%$ das restaurações com Silux foram refeitas, $69 \%$ por causa de perda de estrutura. Todas as restaurações não refeitas foram consideradas satisfatórias por ambos, avaliador e paciente.

Avaliação clínica de restaurações de classe III, IV e V por meio de "ranking" fotográfico foi GALAN JUNIOR et al. ${ }^{67}$, em 1985. Foram fotografadas 40 restaurações estéticas na clínica de pós-graduação (Dentística) da Faculdade de Odontologia de Bauru, com diferentes câmeras fotográficas, sem preocupação em saber o tempo de vida útil das restaurações, nem qual material restaurador havia sido utilizado. Inicialmente foram feitos diapositivos coloridos e após, transformados em fotografias coloridas ampliadas 7 vezes. As fotografias foram recortadas, deixando-se à mostra apenas a restauração em questão. A finalidade destas tomadas era elaborar um "ranking" fotográfico para servir de parâmetro na avaliação de restaurações estéticas. $\mathrm{Na}$ ordenação do "ranking" foram considerados dois aspectos: a combinação de cor e a integridade marginal. Agruparam as fotos das restaurações de classe III, as de classe IV e as de classe $\mathrm{V}$, uma classe separadamente da outra. As fotos mostraram diferentes níveis de alteração, onde facilmente os avaliadores puderam ordenar as fotografias, pois os graus de alteração se mostraram bem definidos. O perfil de desgaste das restaurações (forma anatômica) não permite uma visualização perfeita, sendo que neste caso os autores sugerem uma combinação com o método clínico de sonda e espelho.

SMALES; CREAVEN ${ }^{167}$, em 1985, avaliaram 3 métodos clínicos pela sua adequabilidade em investigar a qualidade das restaurações à amálgama e de resina composta. Características clínicas de ambos materiais, tão bem quanto outras condições 
dentais também foram avaliadas. 1. Observações clínicas diretas das características específicas das restaurações e condições dentais selecionadas foram feitas e os seguintes critérios foram usados para avaliação. Os escores foram limitados a uma escala de 4 (0 a 3) ou 2 (0 e 1), respectivamente. Não foram feitas radiografias ou testes de vitalidade pulpar. Com a escala de 0 a 3, escores foram os seguintes: 0 = bom, 1 ou 2 = adequado e 3 = insatisfatório (substituição/reajuste). Para os seguintes sintomas clínicos 0 (zero) indicava a ausência da condição. Pobre forma anatômica, margens com sobre ou subcontorno, placa na restauração ou no dente, gengivite adjacente à restauração, atrição oclusal/incisal da restauração ou do dente, rugosidade de superfície, superfície manchada/pigmentada, descoloração marginal, fratura marginal, cor/opacidade da resina com o dente. Para os seguintes sintomas, um sistema simples de escores de $0=$ não e $1=$ sim foi usado para indicar presença ou ausência da condição. Desde presença de gengivite generalizada passando por 11 fatores até cárie recorrente das restaurações foram avaliadas. 2. Observações clínicas indiretas de características selecionadas das restaurações foram feitas com diapositivos coloridos (Ektachrome $35 \mathrm{~mm}$ ) com aumento de 1:1. 3. Observações clínicas indiretas de características selecionadas das restaurações foram feitas usando moldes matrizes de gesso pedra onde eram colocadas as impressões totais dos arcos feitas com alginato. Os resultados foram significantemente diferentes entre os métodos de avaliação clínica direta e indireta para muitas das características clínicas das restaurações à amálgama e de resina composta para ambos os avaliadores. Os métodos indiretos foram geralmente mais críticos nas condições das restaurações.

CÉSAR et al. $^{32}$, em 1986, avaliaram clinicamente 28 incisivos centrais superiores fraturados, de pacientes da Faculdade de Odontologia de Bauru, que foram preparados em bisel ou ombro, com extensão igual a 1/4 da extensão da fratura. Esta extensão 
foi medida com paquímetro. Os dentes foram restaurados com resina composta, sob isolamento absoluto. As avaliações foram feitas aos 6 meses e 1 ano por 2 examinadores especialmente treinados e calibrados, de acordo com os seguintes ítens: retenção, combinação de cor e forma anatômica, segundo os critérios descritos por Ryge e adaptados para a pesquisa. Quanto à retenção foram considerados 3 níveis: 0 - retenção total, 1 - retenção parcial, 2 - desprendimento total; quanto à combinação de cor foram considerados os seguintes escores: 0 - em harmonia com a cor natural do dente, 1 - em desarmonia parcial com a cor do dente, porém aceitável, 2 - em desarmonia total com a cor do dente e inaceitável clinicamente; quanto ao contorno foram considerados 3 escores: 0 - o material está em continuidade com a superfície não preparada do dente, 1 - perda parcial do contorno anatômico e 2 - perda acentuada do contorno da restauração. Foram também feitas fotografias nos 2 períodos de avaliação. Não foram verificadas diferenças estatisticamente significantes entre os dois tipos de preparos, apesar de se verificar alguma vantagem para o preparo em ombro.

DAVIS; MAYHEW ${ }^{45}$ compararam clinicamente 5 características de uma resina composta convencional (Concise), uma de micropartículas quimicamente ativada (Silar) e uma de partículas pequenas fotopolimerizável (Prisma fil), em 1986. Vinte e oito conjuntos de 3 restaurações de classe III foram feitas em 20 pacientes, com idades entre 25 e 62 anos, com uma média de 48 anos. Apenas 1 clínico realizou todos os procedimentos operatórios. Proteção pulpar foi feita com uma base de hidróxido de cálcio (Dycal) aplicado em todas as superfícies dentinárias expostas. O acabamento inicial foi feito com brocas multilaminadas (12 lâminas) e o final com discos de óxido de alumínio e lixas (Sof-Lex) e ainda com pontas de acabamento de resina composta. $\mathrm{O}$ "baseline" foi feito dentro de 1 mês da restauração colocada usando o sistema de escoreamento estabelecido por Cvar; Ryge 
(1971) para a forma anatômica, adaptação marginal, descoloração marginal, rugosidade de superfície e cor. Dois avaliadores foram treinados e um nível de $85 \%$ de concordância inter e intra-examinadores foi alcançado. Quando havia discordância na classificação, os avaliadores chegavam a um acordo de um escore aceitável a cada exame. Nenhum examinador era informado a respeito de qual resina ele estava avaliando. Pacientes foram agendados após 1 ano e 3 anos. Em 1 ano, 23 conjuntos de restaurações foram avaliadas e aos 3 anos, 17 dos 28 conjuntos originais foram avaliados. O teste exato de Fisher foi usado para análise dos dados. Todas as resinas comportaram-se bem e não foram significantemente diferentes umas das outras na avaliação de 1 ano. Após 3 anos, todos os materiais foram considerados satisfatórios, mas a resina composta convencional apresentou significantemente mais rugosidade de superfície que as outras resinas. Todas as resinas compostas também deterioraram a cor após 3 anos.

A qualidade clínica e a durabilidade das marcas de cada um dos 3 tipos de resina composta ( 2 convencionais, 2 híbridas e 3 de micropartículas), em cavidades de dentes anteriores, durante um período de 6 anos, foram avaliadas por VAN DIJKEN ${ }^{189}$, em 1986. Descoloração extrínseca, descoloração intrínseca, descoloração marginal, adaptação marginal, rugosidade de superfície e cárie recorrente foram investigados. O aumento da cárie foi comparado com uma estimativa de risco de cárie esperado dos indivíduos. A estimativa foi baseada no efeito rede da contagem microbiana, higiene oral, quantidade de fluxo salivar, capacidade tampão e entrada de carboidratos fermentáveis. A variação dos fatores investigados dentro de cada grupo de resina composta foi muito grande para permitir combinação dos resultados. Os materiais individuais são, portanto, apresentados e comparados. Escores de cor inaceitáveis (descoloração intrínseca) após 6 anos variou muito entre as marcas $(3,5 \%$ - 79,7\%). Descoloração marginal inaceitável foi vista em $1,7 \%$ das 
restaurações, ao passo que, adaptação marginal inaceitável variou entre 13,7\% e 37,3\%. Cárie recorrente ocorreu nas margens de $18,9 \%$ das restaurações de resina composta (variando de 9,3\% - 29,4\%) durante o período. A freqüência cumulativa relativa de restaurações substituídas para os materiais variou entre $14,8 \%$ e 55,1\%. Cárie recorrente foi a maior razão para substituição.

CRUMPLER et al. ${ }^{42}$, em 1988, avaliaram, por meio de um trabalho clínico, as qualidades estéticas de 3 resinas de micropartículas (Finesse, Silar, Superfil) versus 1 resina composta convencional (Concise) num período de 5 anos. Aproximadamente 28 amostras de cada material foram inseridas em preparos cavitários convencionais de classe III. Em cada caso uma fina camada de cimento de hidróxido de cálcio foi aplicada na dentina. Para um efetivo controle de umidade, a preparação e subsequente restauração de todos os dentes foi realizada com isolamento absoluto instalado. Cada restauração foi examinada por 2 avaliadores no "baseline", 6 meses, 1, 2 e 5 anos. Um total de 110 amostras, em 52 pacientes, foram avaliadas usando o exame clínico direto, de acordo com o sistema USPHS desenvolvido por Cvar; Ryge, para as categorias cor, descoloração marginal, cárie secundária, forma anatômica (desgaste) e adaptação marginal. Textura de superfície também foi avaliada como categoria adicional para cada restauração. Para esta categoria, se a superfície exibisse uma superfície lisa parecida com o esmalte, recebia escore Alfa; uma superfície granular rugosa tipicamente vista nas resinas compostas convencionais, recebia escore Bravo; uma restauração que mostrava uma superfície irregular com reentrâncias, recebia escore Charlie. Um consenso era obtido quando os avaliadores discordavam em algum escore. Comparações estatísticas entre os materiais foram baseadas nos testes do Qui-quadrado. Aos 5 anos, 57\% das 110 restaurações originais foram observadas. Apesar de exibir uma textura de superfície lisa, as resinas microparticuladas apresentaram mais alteração de cor que a convencional. O 
nível de cor ideal, aos 5 anos, foi de 53\% para Finesse, 27\% para Silar e 13\% para Superfil em comparação com $71 \%$ da controle Concise. As resinas de micropartículas obtiveram a maior incidência de descoloração marginal, embora não fosse estatisticamente significante da que serviu de controle. Todos os materiais comportaram-se igualmente bem com relação à cárie secundária, forma anatômica e adaptação marginal.

Por meio de um questionário que foi enviado para 341 CirurgiõesDentistas que haviam se registrado para participar nos curso de pós-graduação em Dentística, QVIST; QVIST; MJÖR ${ }^{135}$, em 1990, realizaram um estudo sobre o uso dos materiais e as razões para a confecção de 2542 restaurações estéticas na Dinamarca. A esses profissionais foi solicitado para anotarem as informações a respeito das restaurações: se eram feitas por causa das cáries primárias ou se feitas para substituir uma restauração antiga. E, se substituíam restaurações, tinham que anotar a maior razão para essa substituição; se era por cárie primária ou uma das nove diferentes razões que seriam: cárie secundária, descoloração marginal, alteração de cor, discrepâncias marginais, forma anatômica, fratura da restauração, fratura do dente, perda da restauração, ou ainda outras razões. Quando se trocavam as restaurações, os mesmos tinham que anotar as informações sobre a antiga restauração e sobre a nova, o material usado e a idade aproximada em anos da antiga restauração com base na informação das anotações. Em adultos, 38\% de todas as restaurações foram inseridas por causa de cáries primárias e $62 \%$ foram substituídas das restaurações que falharam. Nas crianças, cárie primária foi a razão para se confeccionar $68 \%$ das restaurações em dentes decíduos e $77 \%$ em dentes permanentes. Materiais resinosos foram os mais frequentemente usados para as restaurações estéticas, exceto nos tratamentos de dentes decícuos, para as quais o cimento de ionômero de vidro foi usado preferencialmente. Cimento de silicato foi usado em menos de $2 \%$ das restaurações estéticas e as poucas restaurações de cimento de silicato 
foram substituídas por materiais resinosos. As razões para substituição das restaurações resinosas foram dependentes da dentição, da idade do paciente e tipo da restauração. Cáries secundárias, fratura da restauração e perda da restauração foram as falhas mais frequentemente anotadas. A idade das restaurações substituídas variou de 0 a 19 anos e a metade das restaurações que falharam, nos adultos, tinham mais de 6 anos de idade. Em dentes permanentes, em crianças, metade das restaurações de resina falharam e foram substituídas dentro de 2 anos, ao passo que metade daquelas em dentes decíduos foram substituídas dentro de 1 ano.

WILSON $^{197}$, em 1990, apresentou a importância e o valor da relação entre as principais formas de investigações laboratoriais e clínicas, donde conclui-se que as formas existentes prestam-se como valioso propósito e proporcionam informações que contribuem para o entendimento e o conhecimento dos materiais. Os testes laboratoriais não dependem de pacientes e são livres de quaisquer variáveis e dificuldades operacionais, as quais exercem grande influência nos achados dos estudos clínicos. As 3 principais formas de investigação laboratorial são consideradas: investigações de parâmetros físicos; de propriedades biológicas, de simulação in vitro (modelos de simulação clínica, ambiente oral artificial). Parâmetros físicos podem incluir investigações intrínsecas dos materiais, a massa, propriedades da superfície; equilíbrio versus propriedades tempo-dependentes; propriedades mecânica, química e térmica; e a interação do material com a radiação. Testes de propriedades biológicas podem avaliar citotoxicidade, mutagenicidade e carcinogenicidade com a toxicidade clínica direta dos materiais sendo testados in vitro e in vivo usando vários sistemas de cultura de células, humanos e primatas. Ambos os testes in vivo e as formas tradicionais de teste in vitro, entretanto, têm um número de limitações e proporcionam resultados que têm uma pobre correlação com os resultados obtidos em situações clínicas. As investigações de 
simulação in vitro - modelos de simulação clínica - são usados extensivamente em avaliações da maioria dos tipos principais de materiais dentários clínicos, especialmente restauradores. Usando modelos clínicos simples, muitos aspectos da superfície, adaptação e características interfaciais dos materiais restauradores têm sido investigados incluindo técnicas largamente usadas como as avaliações microscópicas de superfícies e técnicas para observar a qualidade dos sistemas restauradores em selar a margem e a interface e mais objetivo, técnicas sistemáticas tais como as que envolvem análise quantitativa da margem. Nas investigações de simulação in vitro - de ambientes orais artificiais, 3 componentes básicos são requeridos: uma saliva artificial que reaja com os materiais testados de uma maneira similar ao que ocorre in vivo; flutuações da temperatura, aeração e variações de umidade comparáveis às encontradas na boca e forças e movimentos encontrados durante a mastigação. Dentro dos estudos clínicos, as principais formas de investigações são: os estudos explanatórios, os pragmáticos e os de observação. Os estudos explanatórios são conduzidos sob condições controladas que favorecem o sucesso e ótima efetividade. A maioria das pesquisas clínicas publicadas na literatura são explanatórias, tipicamente conduzidas nas Faculdades de Odontologia envolvendo um número pequeno de investigadores especialmente treinados com o intuito de fazer restaurações de ótima qualidade num grupo altamente selecionado de pacientes. Os estudos clínicos pragmáticos são os que testam a performance e a efetividade dos materiais na situação do mundo real. Um grupo representativo de profissionais usam os materiais que estão sendo estudados numa amostragem relativamente grande de pacientes, que deveriam ser representativos da população na qual os materiais podem eventualmente ser usados. Os benefícios incluem boa indicação da sensibilidade técnica do material, susceptibilidade a aplicação não apropriada e aceitação do paciente. Os estudos clínicos de observação podem ser longitudinais (retrospectivos ou prospectivos), nos quais os dados são coletados das 
anotações dos pacientes ou secção-cruzada, envolvendo o exame de uma amostra de pacientes. Estudos de observação longitudinais são feitos principalmente para medir durabilidade, enquanto estudos de secção-cruzada proporcionam uma indicação da qualidade, por exemplo, das restaurações numa amostra da população num dado tempo. Os estudos clínicos de observação, com exceção dos tipos longitudinais prospectivos, podem ser completados relativamente rápido já que não dependem de retornos de pacientes para revisões em períodos de vários anos.

Tabela 3 - Principais formas de investigações laboratoriais e estudos clínicos

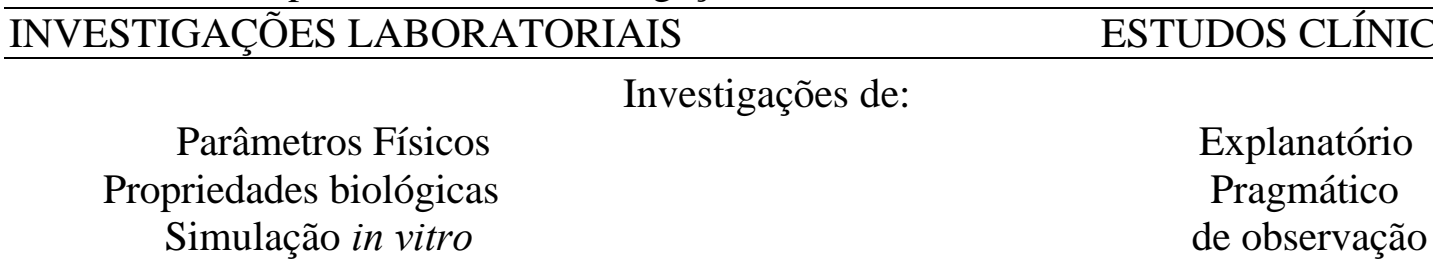

Fonte: WILSON, N. H. F. The evaluation of materials: relationships between laboratory investigations and clinical studies. Oper. Dent., v.15, n.4, p.149-55, July/Aug. 1990.

O efeito de vários cremes dentais sobre as resinas compostas híbridas foi estudado por GOLDSTEIN; LERNER ${ }^{69}$ em 1991. Os autores queriam determinar se os produtos disponíveis no comércio produziam uma diferença na rugosidade da superfície das resinas restauradoras. $\mathrm{O}$ efeito de uma mistura de $100 \mathrm{~g}$. de dentifrício/100 g. água de 8 cremes dentais (Colgate, Crest, Viadent, Supersmile, Shane, Sensodyne, Rembrandt e Topol) sobre 48 amostras da resina composta Herculite (Kerr) foi testado. Os espécimes foram escovados 20.000 vezes e as alterações na lisura de superfície foi analisada com um profilômetro. A resina composta era inserida em uma matriz de $10 \mathrm{~mm}$ de diâmetro por $3 \mathrm{~mm}$ de espessura e antes de ser fotopolimerizada, era comprimida entre duas placas de vidro. Depois era armazenada em água a $37^{\circ} \mathrm{C}$ por 1 semana até o momento dos testes. Seis leituras representativas eram feitas em cada amostra de resina composta. A topografia da superfície da resina composta híbrida foi alterada pela escovação de rotina, embora o efeito do creme dental 
Colgate foi o que produziu estatisticamente a superfície mais lisa que as encontradas com os outros dentifrícios.

A estabilidade de cor de resinas compostas indiretas selecionadas (Dentacolor - Kulzer Inc.; Visio-Gem - Espe; Brilliant D.I. - Coltene Inc.; Concept - Williams Dental Co.) foi avaliada por KHOKHAR; RAZZOOG; YAMAN ${ }^{91}$ em 1991. Vinte e seis espécimes de cada resina composta foram expostos a fluidos comuns da dieta (café e chá) e a agentes químicos comumente usados para higiene oral em casa (gluconato de clorexidina 0,12\%). Os espécimes foram confeccionados e depois imersos nas soluções. O efeito modificador da saliva no manchamento também foi estudado. Três espécimes de cada material testado foi usado como controle (foram armazenados em água destilada, em ambiente escuro). Os espécimes foram montados numa roda dentada que rodava a $1 \mathrm{rpm}$, alternadamente imergindo e retirando cada espécime por 15 segundos e 45 segundos, respectivamente. Os dados da cor foram conseguidos usando o "Minolta Chroma Meter II Reflectance" e analisados pelo Processador de dados Minolta DP-100. As medidas de cor foram tomadas no "baseline" e 6,12, 24 e 48 horas. Café e chá pigmentaram os materiais testados, mas o chá manchou mais que o café. A adição da clorexidina e saliva aumentou o manchamento quando usado com o chá. A maioria dos manchamentos foi superficial e pôde ser removido com higiene oral regular, entretanto, manchamento residual, o qual deve tornarse cumulativo, foi anotado. As amostras de Brilliant D.I. exibiram a maior descoloração e as amostras de Concept, a menor.

ROULET; SEEWALDT; NOACK ${ }^{143}$, em 1991, realizaram um estudo com o propósito de determinar a qualidade das margens de restaurações de classe III e IV, restauradas com resinas compostas híbridas e de micropartículas. Dois experimentos in 
vitro foram conduzidos. No experimento 1, pequenas cavidades de classe III biseladas foram preparadas em 24 incisivos, sendo 12 restauradas com uma resina composta de micropartículas experimental (Compafill) e 12 com um material de micropartículas controle (Durafill). No experimento 2, cavidades de classe IV, grandes, padronizadas, biseladas, foram preparadas em 24 incisivos, sendo 12 restauradas com Durafill e 12 com a resina composta híbrida Herculite XR. Os dentes foram armazenados em água, por 21 dias, a $22^{\circ} \mathrm{C}$. Antes e depois as restaurações foram termocicladas $\left(5^{0} \mathrm{C}-55^{0} \mathrm{C}\right)$, réplicas foram obtidas para análise quantitativa no MEV. Análise estatística revelou que os 2 materiais microparticulados comportaram-se muito bem (mais de 95 de margens excelentes) em restaurações de classe III, antes de serem termocicladas. Após a termociclagem, a qualidade da margem da resina Durafill diminuiu para $90 \%$ de excelência, devido ao aumento nas fraturas da restauração. A termociclagem não afetou a qualidade da margem nas cavidades de classe IV e a resina híbrida mostrou qualidades de margem superiores (89\% excelente). Qualidades de margem superiores foram obtidas nas cavidades de classe III. Restaurações de classe IV mostraram mais sobrecontornos $(12 \%)$ e subcontornos $(6 \%)$, as quais foram relacionadas à técnica.

Em 1991, UM; RUYTER ${ }^{185}$ expuseram 2 materiais, à base de resina, ativados por luz, para restaurações indiretas e 3 polimerizados pelo calor, ao café fervendo (bem quente), café filtrado ou chá a $50^{\circ} \mathrm{C}$ e avaliaram-nos com relação à estabilidade de cor. Espécimes imersos em água destilada, no escuro, a $37^{0} \mathrm{C}$, por 4 meses também foram avaliados. Um material ativado por luz resistiu a descoloração intrínseca durante o tempo de imersão em água destilada e em soluções que produzem manchamento. A descoloração dos outros materiais, pelo chá, foi principalmente devido a adsorção de superfície dos corantes. Descoloração pelo café foi devido a adsorção e também a absorção dos corantes por 2 dos materiais investigados. Esta absorção e penetração dos corantes na fase orgânica dos materiais 
para restaurações indiretas foi devido, provavelmente, a compatibilidade da fase polimérica com os corantes amarelos do café.

A investigação da sobrevivência das resinas compostas em dentes anteriores feitas com ou sem condicionamento ácido, usando uma resina de união ao esmalte de baixa viscosidade (Enamel-bonding), por períodos de aproximadamente 16 anos foi realizada por SMALES ${ }^{163}$, em 1991. As 950 restaurações de resina composta convencional (Concise) foram confeccionadas por estudantes e Cirurgiões-Dentistas para pacientes do “Departamento de Odontologia do Hospital Real de Adelaide". Falhas verdadeiras resultavam da fratura, mobilidade, reparo ou substituição de restauração e cárie secundária. Falhas aparentes contaram $13 \%$ do total das falhas e incluiu aquelas restaurações perdidas por preparos de acesso endodôntico, extrações, trauma ou da incorporação de outras restaurações, mas foram excluídas da análise. Avaliou-se especialmente o método de colocação (Concise e Concise EB), tipo de restauração (classe III,IV,V), idade do paciente (0-20 anos, 21-40 anos, 41-60 anos, 61 anos ou mais) e o Cirurgião-Dentista (se era da Universidade ou do Hospital). Não foram anotadas diferenças estatisticamente significantes entre os 2 métodos de colocação ou entre os 2 grupos de profissionais, se da universidade ou do hospital. Entretanto, houve significantemente mais falhas com as restaurações de classe IV e o grupo de pacientes mais idosos (61 anos ou mais). O esmalte condicionado e uma resina de união ao esmalte não significou uma vantagem sobre os preparos cavitários não condicionados. O período de vida média para ambos os métodos de colocação de resina composta foi de 8 - 9 anos.

Num estudo prévio, SMALES avaliou resinas compostas para dentes anteriores por mais de 16 anos, colocadas com e sem condicionamento ácido e um agente de união e não encontrou diferenças estatisticamente significantes na longevidade entre 
qualquer um dos 2 métodos de colocação da resina composta. Em 1991, SMALES $^{164}$ avaliou as restaurações daquele estudo no sentido de verificar quaisquer diferenças que pudessem haver na deterioração de vários fatores clínicos ou características que se acreditasse afetar o tempo de vida útil da resina composta. Foram feitas 950 restaurações por muitos operadores. Estas restaurações foram examinadas por meio de observações clínicas diretas suplementadas por diapositivos coloridos. Os fatores clínicos avaliados foram, manchamento de superfície, descoloração marginal, fratura marginal e cor. Cada fator possuía uma escala de 0 a 3 , onde 0 (zero) representava a não detecção de qualquer deterioração (bom), 1 (um) leves mudanças e 2 (dois) mudanças óbvias a partir do ideal (adequado) e 3 (três) mudanças severas que requeriam alguma forma de tratamento (insatisfatório). Diferenças significantes na deterioração foram encontradas para vários dos fatores clínicos avaliados para os 2 métodos de tratamento (colocação) da resina composta. Apesar dessas diferenças na deterioração das restaurações, a vida média dos 2 métodos de colocação da resina composta foi muito similar. Todos os fatores clínicos se deterioraram com o passar do tempo para a resina composta.

BERASTEGUI et al. ${ }^{13}$, em 1992, avaliaram os resultados do polimento de resinas compostas usando as seguintes técnicas de acabamento e polimento: pedras de Arkansas, brocas multilaminadas (8 lâminas), pontas diamantadas, discos de óxido de alumínio, brocas multilaminadas (12 e 30 lâminas) e sem polimento. Os resultados foram comparados para averiguar qual técnica levaria à uma superfície mais lisa. O estudo foi feito com 120 restaurações de classe V, em dentes humanos extraídos, distribuídos em 2 grupos (I e II) de 60 restaurações cada. O grupo I era composto de dentes amostra restaurados com resina composta de micropartículas e o grupo II com resina composta híbrida. Leituras foram feitas com um profilômetro para avaliar o polimento final. As conclusões dos resultados do estudo foram que as resinas compostas microparticuladas proporcionaram um melhor acabamento 
quando tratadas com discos de óxido de alumínio. Estes resultados foram estatisticamente significantes. Quando a resina composta híbrida foi usada, os mais baixos valores foram anotados para o grupo controle.

Avaliar clinicamente uma resina composta para dente anterior por meio de microscopia eletrônica de varredura foi a proposta de SALEH et al. ${ }^{152}$, em 1992. Noventa e três restaurações de classe III e V colocadas em pacientes com idade entre 12 e 50 anos foram avaliadas no "baseline", 6 meses e 1 ano. Aproximadamente metade dos pacientes eram mais jovens que 18 anos. As amostras foram divididas em 2 grupos e um CirurgiãoDentista experiente foi designado para cada grupo para executar as restaurações. Ambos os Cirurgiões-Dentistas receberam o mesmo treinamento profissional e usaram a mesma técnica. A maioria das restaurações $(87 \%)$ eram classe III. Não havia limite de restaurações por paciente. A aparência da superfície, cor e adaptação marginal de cada restauração foi avaliada no "baseline" e em todos os retornos. Descoloração marginal, forma anatômica, cárie secundária e resposta do tecido gengival foram avaliadas nos retornos de 6 meses e 1 ano. Restaurações escolhidas aleatoriamente foram fotografadas e replicadas para observação no microscópio eletrônico de varredura. As avaliações foram feitas por um dos operadores e um segundo avaliador experimentado que havia sido treinado. A adaptação marginal foi avaliada clinicamente com um explorador. Radiografias foram tomadas das restaurações suspeitas de terem cárie secundária. Sessenta e quatro (79\%) das 81 restaurações examinadas na chamada de 1 ano não mudaram. Descoloração marginal (10) e mudanças na aparência da superfície (17) e adaptação marginal (15) foram as responsáveis pela maioria das mudanças. Na categoria da resposta do tecido gengival, 18 restaurações haviam sofrido alteração. Todas as mudanças aconteceram em pacientes mais jovens que 14 anos, as quais podem indicar que os pacientes não possuíam boa higiene oral. Réplicas de restaurações selecionadas 
aleatoriamente mostraram superfícies lisas e margens bem seladas com uma zona de transição lisa da restauração para o esmalte. Algumas restaurações mostraram falhas marginais e uma superfície irregular.

Em 1992, SMALES ${ }^{165}$ avaliou a conseqüência do uso do isolamento absoluto ou do isolamento relativo na deterioração clínica de 546 restaurações a amálgama e 148 restaurações com resina composta em dentes anteriores, em períodos acima de 15 e 10 anos, respectivamente. Foram avaliados vários fatores clínicos das restaurações, usando métodos de observação direta e indireta. Para as resinas compostas foram observados: rugosidade de superfície, manchamento de superfície, descoloração marginal, integridade marginal e cor. Com muito poucas exceções, todas as restaurações feitas foram de alta qualidade e houve relativamente poucos escores insatisfatórios dados para qualquer um dos fatores clínicos avaliados. A baixa média dos escores de deterioração para a maioria dos fatores clínicos avaliados foram, também, bastante similares, independente do método de isolamento usado. Embora uma diferença estatisticamente significante fosse encontrada entre os dois métodos de isolamento, para a fratura marginal das resinas compostas, a relevância clínica dessa diferença é questionável. Outrossim, apesar de que todos os estudos fossem incapazes de sustentar que o isolamento absoluto proporciona uma ótima performance da restauração, o uso do mesmo, corretamente instalado propicia condições ótimas de operação e constitui-se num importante e crescente aliado no papel odonto-legal, em evitar riscos potenciais aos pacientes que podem surgir da aspiração ou deglutição de objetos e também possivelmente da infecção cruzada. Por essas razões seu uso deve ser fortemente recomendado.

SMALES; GERKE ${ }^{168}$, em 1992, compararam o comportamento 
clínico de 4 resinas compostas para dentes anteriores, sob condições controladas e avaliaram durante 5 anos. Um total de 439 restaurações foram realizadas em preparos convencionais em dentes anteriores de 86 pacientes, por um operador. Foram feitas 340 classes III, 38 classes IV, e 61 classes V, sendo a maioria, $81 \%$ em dentes superiores e $63 \%$ em grupos de pacientes de 21 a 40 anos. As restaurações foram avaliadas imediatamente após a colocação e em intervalos de 6 meses para os seguintes critérios: gengivite adjacente, manchamento superficial, manchamento marginal e cor. Cada um dos fatores clínicos era ranqueado numa escala ordinária de 0 a 3; 0 , sem alterações; 1, leves mudanças a partir do ideal; 2, mudanças óbvias e 3, mudanças severas requerendo alguma forma de tratamento. No final dos 5 anos, os autores avaliaram somente 67 restaurações, não somente porque as restaurações falharam, mas principalmente porque os pacientes não foram localizados. As classes IV tiveram falhas significativamente maiores que as classes III e V. Gengivite também foi notada com maior freqüência nas grandes classes IV. Nas classes V, o manchamento de superfície encontrado foi menos significante. As duas resinas compostas microparticuladas mostraram mais manchamento marginal do que a de partícula convencional grande e a híbrida. O menor manchamento marginal ocorreu nas classes III. Todos os 4 materiais, com o tempo, deterioraram em graus ligeiramente diferentes para os diferentes fatores clínicos. Mas houve muito poucos escores insatisfatórios para qualquer dos materiais e a maioria das mudanças foi leve (escores 1). As restaurações dos diferentes preparos cavitários também deterioraram em graus variados no período de 5 anos, dependendo do seu tamanho, local e acessibilidade para limpeza. Em suma, as 4 resinas compostas mostraram poucas falhas ou restaurações insatisfatórias em períodos de 5 anos ou mais.

Em 1992, 700 restaurações com resinas compostas fotopolimerizáveis foram realizadas, por 1 pesquisador, em dentes permanentes anteriores de 
161 pacientes e avaliadas durante 4 anos por SMALES; GERKE ${ }^{169}$. Uma resina composta microparticulada e 2 resinas híbridas foram observadas quanto: ao seu manuseio, à compatibilidade com a gengiva, ao manchamento de superfície, à descoloração marginal e a cor. As resinas compostas foram polimerizadas em incrementos de 2,0 $\mathrm{mm}$, o acabamento e polimento foi dado com brocas multi-laminadas, discos e tiras graduados Sof-Lex e taças e pontas impregnadas de pasta abrasiva. As restaurações foram avaliadas imediatamente após a colocação e em intervalos de aproximadamente 6 meses. Diapositivos coloridos também foram usados. Cada um dos 4 parâmetros clínicos foi taxado usando uma escala linear de 0 a 12; 0 (zero) representando nenhuma detecção de qualquer deterioração e 12 (doze) indicando severa deterioração que requeria tratamento. Falhas foram relacionadas ao material, idade do paciente, localização do dente e classe de preparação. As diferentes propriedades de manuseio das 3 resinas compostas não afetaram seu comportamento clínico. Houve somente 10 casos instisfatórios das 1626 observações das restaurações para os 4 parâmetros clínicos avaliados e nenhuma diferença clinicamente significante foi encontrada entre os 3 materiais, com exceção da combinação de cor mais clara inicial da resina composta microparticulada. Não observouse alteração clínica óbvia na maioria das restaurações pesquisadas, embora deteriorassem levemente ao longo do estudo. Não houve diferenças significantes nas falhas entre as 3 resinas compostas, embora, significantemente, tenham ocorrido mais falhas em pacientes mais idosos, em restaurações de classe V, em premolares e preparos de classes IV e V. Das 43 falhas das restaurações, $81 \%$ foram dos preparos de classe V, a qual refletiu a confiança indevida nos sistemas de união dentinária para retenção das restaurações em lesões cervicais de erosão-abrasão em premolares.

Em 1993, VAN NOORT; DAVIS ${ }^{192}$ estudaram a performance clínica de 6 resinas compostas ativadas quimicamente, consistindo de 3 convencionais 
(Adaptic, C.R.M., Healthco); uma de micropartículas (Silar); uma de partículas pequenas (Brilliant) e uma híbrida (Miradapt), quando usadas para restaurações de classe III e V num grupo de amostras na prática geral (clínica geral). O intuito desse estudo foi: (1) determinar se é possível acumular dados na base de perspectiva de um número de clínicos gerais num período de pelo menos 5 anos; (2) para avaliar se há qualquer diferença notável no comportamento entre um número de resinas compostas para dentes anteriores; (3) para determinar as razões para substituição vista pelos clínicos gerais. Vinte e seis clínicos gerais participaram deste trabalho confeccionando 50 restaurações, com 1 restauração por paciente, de classe III ou V para cada resina composta, totalizando 300 restaurações por CirurgiãoDentista e um total geral de 7800 restaurações por avaliação. O estudo foi iniciado em 1983 e os dados foram coletados por 7 anos. Todas as restaurações foram feitas no período inicial de 18 meses, assim todas puderam ser acompanhadas por 5 anos. A informação coletada foi analisada para verificar a longevidade clínica e as razões para substituição que foram observadas pelos Cirurgiões-Dentistas que operam no Serviço Dental Geral da Inglaterra. Ao final de 5 anos, 14 Cirurgiões-Dentistas tinham retornos suficientes para seus dados serem considerados adequados para análise. Eram 2399 restaurações de classe III e 1093 de classe V. A probabilidade de longevidade aos 5 anos foi $62,9 \%$ para as classes III e 71,8\% para as classes V. As principais razões para substituição foram descoloração superficial generalizada, cárie secundária e fratura.

Os efeitos do isolamento absoluto e do isolamento relativo na qualidade inicial e no comportamento clínico posterior de 644 restaurações a amálgama e 149 restaurações anteriores com resina composta foram avaliados por SMALES ${ }^{166}$, em 1993, por períodos superiores a 15 e 10 anos respectivamente. Todas as restaurações foram feitas por um único operador (o próprio autor do trabalho), em dentes permanentes de 105 pacientes e 
suas qualidades avaliadas na hora do acabamento ("baseline"), usando 7 características clínicas (sobrecontorno, subcontorno, rugosidade de superfície, manchamento superficial, manchamento marginal, fratura marginal, alteração da cor). A influência de 6 outros parâmetros clínicos no comportamento posterior das restaurações também foram avaliados (idade do paciente, classe da preparação, tipo de material, pobre saúde bucal, bruxismo e paciente que fuma muito). Não houve diferenças significantes clinicamente presentes na alta qualidade inicial das restaurações ou em seus comportamentos posteriores, os quais podem estar diretamente relacionados ao uso ou não do dique de borracha. No global, o comportamento da restauração foi excelente. Entretanto, houve significantemente mais falhas nas restaurações a amálgama, originadas de porções fraturadas, em pacientes com severo bruxismo.

CHACON; FRANCO ${ }^{33}$, em 1994, avaliaram a extensão de polimerização de uma resina composta (Adaptic II-A) com a utilização de duas cunhas refletivas (Hawe-Neos e TDV). A partir de uma barreira mecânica, constituída de lâminas de chumbo de filmes radiográficos, as cunhas foram introduzidas, perfurando as lâminas, de forma a permitir a fixação com cera, de um anel plástico de $8 \mathrm{~mm}$ de diâmetro e $1 \mathrm{~mm}$ de espessura, do lado oposto ao da fonte de luz. Com o posicionamento da cunha e anel junto à lâmina de chumbo, a resina era inserida, preenchendo o interior do anel. Em seguida, foi realizada a ativação da resina composta, em diferentes tempos de exposição (polimerização), 40, 80 e 120 segundos. Após os referidos tempos, a resina não-polimerizada ao redor da cunha era removida com instrumento cortante, quantificando a resina polimerizada com o auxílio de um paquímetro. Foram confeccionados 5 espécimes para cada tempo de polimerização com as 2 cunhas, totalizando 30 amostras. Os resultados foram analisados estatisticamente chegando à conclusão de que havia diferença significante entre os grupos, 
principalmente em função dos diferentes tempos de polimerização, com superioridade da cunha TDV com o tempo de 120 segundos de ativação.

A efetividade das cunhas refletivas auxiliando a polimerização foi avaliada por CIAMPONI; DEL PORTILLO LUJAN; SANTOS ${ }^{36}$, em 1994. Espécimes prépesados de 0,02 g de resina composta (Estilux, Herculite XR, P-30) foram polimerizados dentro de uma caixa preta, por 30, 60, 90 e 120 segundos, de maneira que somente a luz da unidade fotoativadora pudesse alcançar a resina composta colocada em contato com a cunha. Foram usados 2 tipos de cunhas (Hawe Neos e LD Caulk) também em 2 tamanhos e 3 unidades de luz. Os espécimes polimerizados foram colocados em etanol, sob agitação, por 1 hora para dissolver a porção não polimerizada e depois secos num papel de filtro, dentro de 1 forno a $70^{0} \mathrm{C}$, por 1 hora. Após esse processo, o espécime foi pesado novamente, na mesma balança analítica, para medir a porção remanescente polimerizada através das cunhas refletivas. Outros espécimes polimerizados diretamente sob as unidades de luz foram usados como controles. As diferenças no peso entre os grupos controle e experimental foram calculadas em porcentagens. Três repetições foram feitas, de cada condição, totalizando 432 observações. Quando a fotoativação foi feita através das cunhas refletivas nunca foi alcançada uma completa polimerização. Um aumento no tempo de ativação aumentou o grau de polimerização, exceto para a P-30. O grau de polimerização através das cunhas refletivas mostrou estar altamente correlacionado com a unidade de luz e a resina composta usada. Tempos de ativação de 30 e 60 segundos, através das cunhas refletivas, resultou em polimerização insatisfatória. Segundo esta pesquisa a correta combinação entre cunha refletiva e fonte de luz é muito importante.

Com o intuito de determinar a estabilidade de cor de 5 resinas 
compostas (Charisma-CH; Clerafil CR-CR; Conquest C\&B-CQ; Herculite XRV-H e True Vitality-T), na cor universal, após fotopolimerização e pós-polimerização uma pesquisa foi feita por ELDIWANY; FRIEDL; POWERS ${ }^{54}$, em 1994. A cor antes da polimerização foi o controle. As amostras eram discos de $10 \mathrm{~mm}$ de diâmetro e $1 \mathrm{~mm}$ de espessura. A cor (CIE $\mathrm{L}^{*} \mathrm{a}^{*} \mathrm{~b}^{*} /$ Fonte A) foi medida num fundo branco com reflectância espectral incluído num espectrômetro de reflexão (Macbeth 7000). As diferenças de cor $\left(\mathrm{E}^{*}\right)$ entre as resinas fotopolimerizadas, pós-polimerizadas e as controle foram calculadas. Os testes foram realizados em 5 replicações. Após fotopolimerização, a maior mudança de cor foi com CR, seguida por T e então por $\mathrm{H}, \mathrm{CH}$ e $\mathrm{CQ}$, as quais não foram estatisticamente diferentes. Após a fotopolimerização, $\mathrm{CH}, \mathrm{CR}$ e $\mathrm{H}$ tornaram-se mais escuras e mais amarelas e $\mathrm{T}$ tornou-se mais clara e menos amarela. Após a pós-polimerização, CR mostrou menos mudança de cor e T mostrou mais que a fotopolimerizada. Amostras pós-polimerizadas de $\mathrm{CH}, \mathrm{CQ}$ e $\mathrm{H}$ não mostraram mudanças de cor quando pós-polimerizadas. Para as resinas compostas testadas, a fotopolimerização causou mudanças de cor perceptíveis das cores pré-polimerizadas. Uma vez fotopolimerizadas, as resinas compostas pós-polimerizadas sofreram mínimas mudanças de cor.

Baseados em um teste proposto por ASMUSSEN ${ }^{5}$ apud UM; RUYTER $^{185}$, INOKOSHI; YAMADA; TAKATSU ${ }^{80}$, em 1994, mediram as mudanças de opacidade e cor de vários materiais restauradores estéticos. Foram colocados em anéis acrílicos com diâmetro de $6 \mathrm{~mm}$ e $1 \mathrm{~mm}$ de altura, 4 resinas compostas de polimerização química, 7 resinas compostas fotopolimerizáveis e 3 ionômeros de vidro restauradores fotopolimerizáveis $(n=5)$. Após a polimerização, as amostras foram mantidas a $37^{0} \mathrm{C}$ por 1 semana antes do "baseline" e então foram armazenados em água destilada a $60^{\circ} \mathrm{C}$ por mais de 4 semanas. Mudança de cor foi determinada por um analisador de cor e a coeficiente de 
contraste $\left(\mathrm{C}=\mathrm{Y}_{\text {preto }} / \mathrm{Y}_{\text {branco }}\right)$ representando a opacidade foi calculado. Todas as resinas compostas quimicamente ativadas testadas descoloriram para amarelo escuro ou marrom escuro após 4 semanas. Opacidade diminuiu para 2 resinas macroparticuladas. As resinas compostas fotopolimerizáveis descoloriram levemente, mas a mudança na sua opacidade foi insignificante. Todos os ionômeros mostraram de leves a moderadas diminuições na opacidade, com leve escurecimento acompanhando esse processo. Segundo os autores, a diminuição da opacidade é um fator de descoloração para alguns materiais restauradores estéticos e deve ser causado pela mudança no índice de refração da matriz orgânica dos materiais.

JOKSTAD et al. ${ }^{86}$, em 1994, compararam a performance clínica de 2 resinas compostas quimicamente ativadas com um cimento de silicato por mais de 10 anos. Foram 131 restaurações em 57 pacientes. A indicação para colocação dessas restaurações foi cárie primária ou substituição de restaurações insatisfatórias. A média de idade dos pacientes foi 40 anos (variando de 9 a 72 anos). Hidróxido de cálcio foi aplicado como base em todas as superfícies dentinárias expostas, quando indicado. Isolamento absoluto foi usado sempre. Os clínicos seguiram as instruções dos fabricantes na manipulação dos materiais. Cada paciente recebeu pelo menos uma restauração de resina composta microparticulada. Se uma segunda restauração era indicada, esta era realizada com uma resina de macropartículas ou um cimento de silicato. Todos os pacientes foram chamados para polimento e avaliação "baseline" em duas semanas. Os pacientes foram novamente chamados aos 6 meses e depois a cada ano, onde as restaurações eram avaliadas por 2 Cirurgiões-Dentistas treinados de acordo com o protocolo do sistema USPHS. Todas as restaurações foram fotografadas. Os resultados confirmaram que as resinas compostas tiveram comportamento superior mas com maior índice de cárie secundária que o cimento de silicato. A resina composta de macropartículas 
mostrou melhor comportamento clínico que as de micropartículas. A concordância entre os escores obtidos com os critérios de avaliação direta e os resultantes da avaliação indireta (fotografias) foi relativamente pobre. Os escores indiretos foram geralmente os mesmos ou mais pobres que os escores clínicos diretos. Os resultados indicaram que a avaliação clínica pode ser o menos sensível dos 2 métodos. A discrepância no escoreamento pode, por outro lado, significar que o método fotográfico indireto registra um espectro de reflectância que não é normalmente obtido in vivo.

Em 1994, McCONNELL et al. ${ }^{109}$ compararam a alteração da dimensão linear de 5 resinas compostas após a fotopolimerização, usando a prova da fibra ótica, a qual mede a intensidade da luz refletida como uma função de alteração dimensional. Foram testadas 5 amostras de cada sistema resinoso (Silux - S; Herculite XRV - X; Prisma TPH - T; P-50 - P e Z-100 - Z). Após a fotopolimerização, leituras de alteração dimensional foram tomadas continuamente por 1 hora. Médias das mudanças dimensionais foram calculadas aos 60 segundos e 1 hora após a confecção das amostras. Todas as amostras demonstraram alteração linear aos 60 segundos, sem diferença estatisticamente significante entre elas. Entretanto, as alterações lineares a 1 hora mostrou diferença significante entre as resinas compostas testadas: $\mathrm{S}$ e $\mathrm{P}, \mathrm{Z}$; X e P, Z; T e Z; P e Z (p<0,05). O estudo demonstrou que após a fotopolimerização, as resinas compostas continuam a se contrair a um grau variável, indo, para as resinas estudadas, de 3 a $6 \%$ na primeira hora. Especialmente para a resina composta Z-100 aos 60 segundos $(3,4 \%-36,5 \mu \mathrm{m})$ e a 1 hora $(5,7 \%-59,9 \mu \mathrm{m})$, sendo a que mais contraiu.

Um relato de REEKIE ${ }^{137}$, em 1994, evidencia que há um enorme potencial na colaboração entre o clínico geral e o mundo acadêmico no campo da pesquisa 
dental. O autor mesmo conduziu alguns projetos no seu próprio consultório e disse que deve haver muitos profissionais que gostariam de ter a oportunidade de tomar parte numa pesquisa, dispendendo parte do seu tempo nisso. O custo não seria grande, especialmente se os fabricantes pudessem subsidiar a pesquisa. Seria vantajoso para eles, já que seus produtos ganhariam credibilidade por serem testados por profissionais, seu principal alvo de mercado. O autor está convencido de que a grande maioria dos seus pacientes ficaria muito feliz em fazer parte de tais projetos. Ele, pessoalmente, ficou admirado que em seus 17 anos de profissão, nunca tivessem perguntado sua opinião sobre que tipo de tópicos de pesquisa ele gostaria que fosse publicado e a quais endereçaria seus problemas na Odontologia do dia-adia. Com os profissionais diretamente envolvidos no trabalho, isto certamente mudaria, tanto que ao final verificar-se-iam pesquisas dirigidas por profissionais gerando conhecimentos de valor no trabalho diário e, mais importante ainda, de real benefício para os pacientes.

Num trabalho publicado em 1994, ROULET ${ }^{142}$ externou sua opinião a respeito das pesquisas in vitro e in vivo. Disse que, em contraste com o mundo da ciência e tecnologia, na Odontologia geralmente não há possibilidade de correlacionar os resultados dos testes simulados (in vitro) com os achados clínicos, devido à falta de critérios da avaliação in vitro, a falta de habilidade de diagnóstico in vivo e a falta de validação in vivo dos procedimentos de simulação. Teste in vitro é essencial para propósitos de desenvolvimento. Entretanto, precisamos descobrir as limitações destes estudos e aceitar que nós podemos fazer juízo errado de um material de boa qualidade e avaliar positivamente materiais ruins.

A fim de investigarem a profundidade de polimerização de alguns materiais à base de resina composta, sob condições de testes padronizados e estabelecerem a 
influência da cor e da opacidade do material nessa polimerização, SHORTALL; WILSON; HARRINGTON $^{155}$, em 1995, realizaram uma pesquisa. Seis resinas compostas foram estudadas (Prisma APH - Dentsply, Brilliant - Coltene, Charisma - Kulzer, Herculite XRV Kerr, Pertac-Hybrid - Espe, Z-100 - 3M). Três cores de cada sistema foram avaliadas (Vita A2, A3,5, C2) para profundidade de polimerização e quando os materiais estavam disponíveis em mais de uma opacidade, as variantes "esmalte" e "dentina" eram testadas. A resina composta foi inserida num molde cilíndrico de aço inoxidável com uma cavidade central de 6 X 4 mm. Após irradiação do material por 20 segundos com uma unidade de luz Optilux 400 e a inversão do molde, este foi posicionado centralmente abaixo de uma parte denteada de um penetrômetro digital para avaliar a altura do cilindro polimerizado. Este equipamento consiste de um metro digital, o qual pode ser zerado a qualquer posição dentro de seu percurso total de $12 \mathrm{~mm}$. A precisão de leitura é de $0,01 \mathrm{~mm}$. A força exercida através do dispositivo produz um estresse de aproximadamente $62 \mathrm{MPa}$. O penetrômetro foi colocado dentro do material 30 segundos após o término da irradiação e a leitura para estabelecer a profundidade de polimerização foi feita 15 segundos mais tarde. Cinco testes foram feitos para cada cor e produto. Para os materiais onde foi testada opacidade, o "esmalte" polimerizou a uma profundidade estatisticamente maior para todas as cores testadas. Para a cor A2 houve diferenças significantes menos para Herculite "Enamel" e Z-100, Prisma APH e Brilliant "Enamel", Brilliant "Enamel" e Charisma, Pertac Hybrid e Herculite "Dentin". Para a cor A3,5 houve diferenças estatisticamente significantes entre todos os produtos menos para Z100 e Brilliant "Enamel", Brilliant "Enamel" e Prisma APH, Prisma APH e Herculite "Enamel”, Herculite "Enamel" e Charisma, Brilliant "Dentin" e Pertac Hybrid. Herculite XRV "Enamel”, na cor A2, polimerizou a maior profundidade, 5,57 mm, em média, seguido da Z-100, também na cor A2, com 5,47 mm. Z-100 também polimerizou a maiores 
profundidades tanto para a cor A3,5 quanto para C2, em comparação com as demais resinas compostas.

Um total de 120 cavidades de classe I foram preparadas por ABDALLA; ALHADAINY², em 1996, em molares de 45 pacientes e restauradas com 4 resinas compostas para dentes posteriores: Clearfil Photo Posterior, Z-100, Herculite XR e Heliomolar RO, com o intuito de avaliarem-nas clinicamente. Pelo menos 2 restaurações foram feitas em cada paciente. As restaurações foram observadas por 2 avaliadores independentes, no "baseline", 1 e 2 anos usando o critério do USPHS. Após 1 ano, 111 restaurações $(92,5 \%)$ foram avaliadas e as restaurações feitas com Z-100 ficaram com escore Alfa em todos os critérios testados (cor, forma anatômica, adaptação marginal e descoloração marginal); Clearfil PP, Herculite XR e Heliomolar RO mostraram leves mudanças na cor, forma anatômica e adaptação marginal. Após 2 anos, 104 restaurações (87\%) foram observadas e nenhuma diferença significante foi encontrada na descoloração marginal para todos os materiais testados. Z-100 e Herculite XR foram significantemente mais estáveis na cor que o Clearfil PP e o Heliomolar RO. A avaliação da forma anatômica mostrou a resina composta Z-100 com um valor significantemente maior que os outros grupos. Heliomolar RO revelou a mais baixa porcentagem de adaptação marginal.

Em 1996, BROWNING; DENNISON ${ }^{25}$ investigaram os modos pelos quais restaurações de resina composta classes III, IV e V falham e o critério usado pelos Cirurgiões-Dentistas de Michigan para avaliar a necessidade de se realizar ou substituir essas restaurações e a idade das mesmas no momento da substituição. Melhorias nos critérios usados para decidir quando e como uma restauração deveria ser substituída, resultaria em uma melhor saúde dental para a população, por reduzir o número de visitas dos pacientes e o custo 
do tratamento. Questionários foram enviados para 378 Cirurgiões-Dentistas, que deveriam fazer 9 observações sobre todas as restaurações de resina composta que eles realizaram durante um período de 2 semanas, no verão de 1993. Desses questionários apenas 108 retornaram, participando, portanto, efetivamente da pesquisa, anotando as razões para se realizar ou substituir 1360 restaurações. Dessas 1360 restaurações, 42,8\% foram classificadas como colocação ou realização primária e 57,2\% como substituição. Dessas realizadas primariamente, $80 \%$ foram classificadas como sendo devido a cárie ; 9,1\% fratura dos dentes, 8,4\% por outras razões (lesões de erosão foram especificadas $94 \%$ das vezes). Por classes, cárie foi a causa dominante para classe III $(96,2 \%)$; cárie e outras (erosão) para classe V (77,3\% e 16,4\%); fratura do dente e cárie $(48,9 \%$ e $40,2 \%)$ para restaurações de classe IV. As porcentagens, por categoria, para restaurações substituídas foram: cárie recorrente, 28,6; falha marginal, 14,1; descoloração marginal, 21,7; cor, 4,5; contorno, 1,9; fratura da resina composta, 16,2; fratura do dente, 8,7; e outras causas, 4,3. Então: cárie permanece sendo a causa dominante para a realização e a substituição das restaurações de classe III e V. Fratura dos dentes e das restaurações existentes foram as principais razões para as restaurações de classe IV, tanto para realização primária quanto para substituição. Uma diferença significante foi encontrada entre as proporções de realização primária e substituição das restaurações de classes IV e V. Por classe, metade de todas as restaurações de classe III falhou num período de 10 anos e metade das de classe IV e V, em 5 anos.

Durante 6 meses, BURKE; EARP; FARRELL ${ }^{28}$ testaram a efetividade das unidades de luz fotopolimerizadoras usando Heliotests (Ivoclar Vivadent) e a resina composta Z-100 (3M) com o auxílio de 144 profissionais, em 1996. Das unidades de luz testadas, 10 estavam operando insatisfatoriamente, o que corresponde a 6,9\%. Análise estatística foi realizada para determinar se havia alguma correlação entre profundidade de 
polimerização e outros fatores. Os resultados indicaram que houve uma correlação negativa entre profundidade de polimerização e idade da unidade de luz. Unidades de luz mais velhas tendem a polimerizar as amostras de resina composta a profundidades menores que as unidades mais novas. Também examinaram os resultados para uma possível correlação entre baixa profundidade de polimerização e sintomas clínicos, os quais poderiam estar associados a pobre polimerização da resina composta, mas foram incapazes de encontrar qualquer correlação.

Por meio de um estudo clínico, KIDD; BEIGHTON ${ }^{93}$, em 1996, questionaram a relevância da descoloração marginal e da integridade (valamento/fenda) no grau de infecção da dentina sob as margens das restaurações estéticas. Foi, então, investigado se a linha de manchamento da margem da restauração estética, descoloração da dentina através do esmalte intacto nas margens da restauração e/ou valamento podem prognosticar a presença de dentina infectada abaixo da restauração na junção esmalte-dentina (JED). Além disso, amostras de placa das margens da restauração foram tomadas para determinar se o número e a porcentagem da composição bacteriana da placa na interface dente/restauração estava associada com a atividade de qualquer lesão debaixo dessa interface. Com a aprovação do comitê de ética local, 73 pacientes adultos que se apresentaram no departamento de conservação da Escola Unida de Odontologia e Medicina e que requeriam substituições rotineiras de restaurações foram admitidos na pesquisa. Clinicamente, sítios visíveis (197) na margem dente/restauração foram selecionados em 113 dentes. A margem da restauração e o esmalte adjacente à cada sítio eram observados quanto ao manchamento ou não e os sítios eram graduados como intactos, tendo um valamento estreito $(<0,4 \mathrm{~mm})$ ou um valamento largo (>0,4 mm). Um valamento largo era classificado quando a fenda era maior que $0,4 \mathrm{~mm}$ - diâmetro da sonda periodontal. Trinta sítios com lesões cariosas também foram incluídos. 
Na margem dente/restauração a placa era colhida e a restauração era, então, removida. Anotava-se a JED em cada amostra como dura ou amolecida quando sondada e a dentina era colhida como amostra. As amostras eram turbilhonadas, diluídas e feita a cultura em anaerobiose total, para contagem de estreptococos mutans e lactobacilos. Havia mais bactérias na placa sobre as cavidades de cárie e a dentina era amolecida e bastante infectada. Somente 38 dos 167 sítios sem cavidades de cárie tinham dentina amolecida na JED. Ambas placa e dentina nesses sítios acolheram mais microorganismos. Entretanto, nenhum dos critérios clínicos escolhidos iria prognosticar fidedignamente a presença desta dentina amolecida. Neste estudo, somente uma lesão cariosa na margem da restauração constituiu-se num diagnóstico confiável de cárie secundária.

NEO; CHEW $^{123}$ compararam a performance clínica de 3 modalidades de tratamento de cavidades cervicais não cariosas por 2 anos, em 1996. Foram estudadas 159 lesões cervicais não cariosas restauradas, por um único operador, com cimento de ionômero de vidro (Ketac-Fil/Espe), resina composta (Silux/3M) e agente de união dentinário (Scotchbond Dual Cure/3M) ou pela técnica de sanduíche. As avaliações clínicas foram feitas ao término de 1 semana para o "baseline", ao final de 1 ano e aos 3 anos. O critério descrito por Cvar; Ryge foi usado para avaliar cor, descoloração marginal, forma anatômica, adaptação marginal e retenção. Nesta escala clínica para escores das restaurações, Alpha (A) é clinicamente ideal; Bravo (B) é clinicamente aceitável e Charlie (C) é clinicamente inaceitável. Dois avaliadores independentes observaram as restaurações e qualquer diferença foi harmonizada pelo consenso. Houve uma deterioração generalizada das restaurações com o tempo. Vinte e dois porcento das restaurações de resina composta deslocaram-se aos 3 anos enquanto 95\% das de cimento de ionômero de vidro e $96 \%$ das restaurações sanduíche ficaram retidas. As restaurações de resina composta exibiram o melhor 
comportamento com relação à cor, mas leves mudanças foram evidentes em 1 ano e estabilizou após esse período. Deterioração marginal foi mais pronunciada que a descoloração marginal para todos os grupos. Resultados estatisticamente significantes não foram evidentes para forma anatômica, mas restaurações com cimento de ionômero de vidro sofreram as maiores mudanças, somente $77 \%$ obtiveram "Alpha" após 3 anos.

NEO et al. ${ }^{124}$, em 1996, determinaram o comportamento clínico de 4 materiais restauradores estéticos em lesões cervicais não cariosas no período de 18 meses. Lesões de abrasão vestibulares de 83 dentes foram restauradas com os seguintes materiais: um ionômero de vidro auto-polimerizável, Fuji Cap II; um ionômero de vidro fotopolimerizável, Fuji II LC; uma resina composta híbrida fotopolimerizável, APH/Universal Bond 3 e outra resina composta fotopolimerizável, Lite Fil II A/Imperva Bond. A avaliação no "baseline" e aos 18 meses foram feitas por 2 Cirurgiões-Dentistas usando o método de Cvar; Ryge modificado (USPHS) para retenção, cor, adaptação marginal, descoloração marginal, forma anatômica e cárie secundária. A retenção foi anotada como sendo ausente ou presente. Todos os pacientes voltaram para a avaliação de 18 meses. Nenhuma restauração apresentou cárie recorrente na avaliação de 18 meses. Todos os materiais exibiram algum manchamento nas margens, mas só foi estatisticamente significante para as restaurações com APH, onde cerca de $50 \%$ levou escore Bravo aos 18 meses. A forma anatômica permaneceu estável durante a avaliação e não houve diferenças entre os materiais. Um significante número de restaurações sofreu alguma perda na integridade marginal para os 4 materiais. Os resultados de porcentagem Alfa para os 4 produtos foram respectivamente: cor $(9 \%, 48 \%, 57 \%, 55 \%)$, descoloração marginal $(71 \%, 76 \%, 52 \%, 50 \%)$, adaptação marginal $(24 \%, 24 \%, 33 \%, 15 \%)$, forma anatômica $(67 \%, 86 \%, 95 \%, 45 \%)$ e retenção $(100 \%, 95 \%, 100 \%, 65 \%)$. Resultados indicaram que: (1) Fuji Cap II exibiu uma pobre combinação de cor no "baseline", (2) a 
combinação de cor do Fuji II LC foi comparável à resina composta e (3) 7 restaurações de Lite Fil II/Imperva Bond (35\%) deslocaram após 1 ano e meio.

O propósito de um trabalho desenvolvido por AZEVEDO; CATRAMBY; FRANCO ${ }^{8}$, em 1997, foi avaliar várias unidades de luz usando um radiômetro e a intensidade de luz correlata medida com a profundidade de polimerização da resina composta. A intensidade de luz de 15 unidades foi determinada usando um radiômetro (Demetron Curing Radiometer - Model 100). Três espécimes foram preparados para cada unidade. A resina composta, cor universal (Glacier - SDI), foi dispensada diretamente dentro de uma matriz cilíndrica de teflon $(1,0 \mathrm{~cm}$ de altura $x \quad 0,5 \mathrm{~cm}$ de diâmetro). Uma placa de vidro foi colocada em cima da matriz e foi polimerizado por 20 segundos. Uma peça de mão com uma broca de aço n.8 foi conectada a um peso de 320 g para padronizar a pressão na resina composta do lado oposto da polimerização. A profundidade da penetração da broca era determinada assim que cessasse a sua movimentação. A média das profundidades $(\mathrm{mm})$ foram as seguintes: grupo A $\left(50 \mathrm{~mW} / \mathrm{cm}^{2}\right)$ 1,8; grupo B $\left(100-160 \mathrm{~mW} / \mathrm{cm}^{2}\right)$ 3,2; grupo C (200 $\left.280 \mathrm{~mW} / \mathrm{cm}^{2}\right)$ 3,4; grupo D $\left(480-500 \mathrm{~mW} / \mathrm{cm}^{2}\right)$ 3,9; grupo $\mathrm{E}\left(520-550 \mathrm{~mW} / \mathrm{cm}^{2}\right) 6,3$. Foram encontradas diferenças estatísticas entre os grupos. Embora as orientações dos fabricantes sugerissem o uso das unidades de luz somente acima de $200 \mathrm{~mW} / \mathrm{cm}^{2}$, os autores concluíram que os valores de profundidade de polimerização obtidos de 100 e $500 \mathrm{~mW} / \mathrm{cm}^{2}$ não foram diferentes um do outro. Abaixo desta média $\left(50 \mathrm{~mW} / \mathrm{cm}^{2}\right)$ e acima $(520-550$ $\mathrm{mW} / \mathrm{cm}^{2}$ ) foram significantemente diferentes.

A performance clínica de uma resina composta híbrida para dentes anteriores foi investigada por MILLAR; ROBINSON; INGLIS ${ }^{113}$, em 1997. Um total de 44 restaurações de classe III, IV e V foram colocadas em 24 pacientes entre julho e dezembro de 
1985. Cada restauração foi feita por um dos 3 autores do trabalho, sob isolamento absoluto. Dycal foi usado como material forrador da cavidade. Bisel foi feito nas margens de esmalte acessíveis. A resina composta foi colocada em incrementos e fotopolimerizados individualmente. Polimento e acabamento final foi realizado com discos de polimento SofLex. Os autores fizeram um exercício de treinamento da avaliação para se familiarizarem com os procedimentos e critérios a serem aplicados. As restaurações foram avaliadas por 2 dos 3 examinadores usando os critérios baseados no USPHS (para forma anatômica, adaptação marginal, rugosidade de superfície, descoloração marginal, cor, desconforto/sensibilidade). Fotografias foram tiradas para completar as informações do "baseline". Pacientes foram rechamados nos intervalos de 3 meses, 1 ano, 2 anos, 3 anos e 8 anos. O número total de escores "alpha" no "baseline" e nas demais avaliações (3 meses e 1, 2, 3 e 8 anos) para os seguintes parâmetros foram: adaptação marginal (33, 28, 29, 27, 12, 17), forma anatômica $(39,30,32,26,17,15)$, rugosidade de superfície $(34,26,24,23,11,4)$, cor $(24,25,26,24$, $15,12)$ e descoloração marginal $(39,31,30,25,10,9)$. A incidência de cáries secundárias foi muito baixa. Ao final de 8 anos nenhum escore B foi anotado. A maioria das restaurações comportaram-se satisfatoriamente. Embora o Opalux (ICI Dental), em particular, não esteja mais disponível, estes resultados podem ser aplicáveis aos materiais similares disponíveis atualmente.

MARTIN $^{106}$, em 1998, objetivou em seu estudo, examinar as unidades de fotopolimerização (luz visível) na clínica dental, na Austrália, para determinar a adequabilidade da sua produção, padrão de uso e manutenção. Informações coletadas com $4 \%$ dos Cirurgiões-Dentistas australianos indicavam o tipo e a idade da unidade, tempos de polimerização usados, história da manutenção, reposição dos componentes e a leitura da intensidade da luz. A intensidade da luz foi medida usando um radiômetro Demetron 
checando numa fonte de luz de intensidade conhecida. Três leituras foram feitas de cada unidade e foi feita a média das 3 leituras para se conseguir o valor final. A intensidade era dividida em 3 categorias: $400 \mathrm{~mW} / \mathrm{cm}^{2}$ e acima (intensidade adequada); 201-399 $\mathrm{mW} / \mathrm{cm}^{2}$ (intensidade limite, onde um tempo adicional de polimerização seria requerido) e 200 $\mathrm{mW} / \mathrm{cm}^{2}$ e menos (intensidade inadequada). Das 214 unidades de luz examinadas, aproximadamente $27 \%$ ficaram enquadradas na intensidade de $200 \mathrm{~mW} / \mathrm{cm}^{2}$ ou menos, um nível considerado inadequado para polimerizar um incremento de resina composta de $2 \mathrm{~mm}$ de espessura. Outros $26 \%$ estavam entre 201 e $399 \mathrm{~mW} / \mathrm{cm}^{2}$. Este nível pode ser considerado aceitável com tempo de polimerização adicional, entretanto, 44\% dos Cirurgiões-Dentistas usavam 20 segundos ou menos. Uma correlação negativa foi encontrada entre a idade da unidade e a intensidade anotada. Próximo de 50\% dos que responderam aos questionários nunca checaram a produção de luz de suas unidades. Os resultados indicaram que a metade das unidades de luz examinadas não estavam funcionando satisfatoriamente. Uma redução óbvia na intensidade foi notada nas unidades mais velhas.

As razões pelas quais se confecciona ou se substitui as restaurações foi motivo de uma pesquisa concluída por BURKE et al. ${ }^{29}$, em 1999. A cada CirurgiãoDentista participante foi pedido para marcar as razões para confeccioná-las ou substituí-las. A idade e a classe da restauração que estava sendo substituída, tanto quanto o material que estava sendo usado e o que estava sendo substituído. Foram recebidas informações de 9031 restaurações. Das restaurações colocadas, 53,9\% eram em amálgama, 29,8\% em resina composta e $16,3 \%$ em cimento de ionômero de vidro. As razões para colocação e substituição das restaurações foram principalmente cáries primárias (41,3\%), cáries secundárias (21,9\%), fratura dental $(6,4 \%)$, fratura marginal ou degradação $(6,1 \%)$ e outros defeitos não cariosos $(5,8 \%)$. Das restaurações de resina composta, a maioria era de classe III. Para as restaurações 
de resina composta, cáries secundárias e a aparência pobre totalizaram proporções iguais de substituição. Finalmente, de um total de 243 restaurações de classe III, com resina composta, que estavam disponíveis para análise, a média de longevidade dessas restaurações foi de 5 anos. Sumarizando, os resultados indicaram que a cárie primária foi a causa mais comum para se confeccionar uma restauração para os Cirurgiões-Dentistas participantes e cárie secundária foi a razão mais prevalente para a substituição das restaurações a amálgama, resina composta e cimento de ionômero de vidro.

Em 1999, um estudo com o propósito de avaliar a performance clínica, após 1 ano, de um compômero recentemente lançado no comércio odontológico, o F2000 (3M), em cavidades de classe III e V, em dentes permanentes, foi realizado por CRISP; BURKE $^{41}$. Dez profissionais de clínica geral do Reino Unido confeccionaram as restaurações, usaram o sistema adesivo fornecido pelo fabricante, o Clicker (3M) e fizeram parte da avaliação de manipulação desse material. Cinco dos 10 profissionais que iniciaram o trabalho foram chamados para cooperarem com a avaliação de 1 ano do material. Foi pedido a eles que contatassem os pacientes e perguntassem se estariam dispostos a deixar que as restaurações fossem examinadas, no período correto, por um avaliador treinado que viajaria para as diversas localidades. Um total de 46 restaurações (20 classes III e 26 classes V), em 29 pacientes foram observadas. A média de idade das restaurações foi de 1 ano e 2 meses na época da avaliação. O método de avaliação foi o de Ryge modificado para forma anatômica, integridade marginal, textura de superfície, sensibilidade ou desconforto, condição gengival e presença ou ausência de cárie secundária. Todas as restaurações estavam íntegras e nenhuma cárie secundária foi anotada. Ótimos escores foram obtidos em $92 \%$ da avaliação. Nenhum escore inaceitável foi registrado, concluindo-se que as restaurações com F2000, usado em conjunto com seu sistema de união, nas condições de clínica geral, comportaram-se muito 
bem após 1 ano.

Em 1999, SILVA E SOUZA JUNIOR; YAMAUTI ${ }^{157}$ avaliaram clinicamente o comportamento de 3 resinas compostas (com diferentes condicionadores) comparadas com uma liga de amálgama, em restaurações de dentes posteriores. Cento e cinco restaurações foram feitas em premolares e molares com lesões de cárie ou restaurações deficientes, sendo 90 com resina composta e 15 com amálgama, em 19 pacientes saudáveis. Os materiais distribuíam-se da seguinte forma nos grupos: $\mathrm{G}_{1}-$ Scotchbond Multi-Purpose/Z$100(3 \mathrm{M}), \mathrm{G}_{2}-$ Optibond/Herculite XRV (Kerr), $\mathrm{G}_{3}-$ Probond/TPH (Dentsply) e $\mathrm{G}_{4}$ Dispersalloy (Dentsply). Após 2 anos, 98 restaurações estavam disponíveis para serem examinadas. Cada restauração foi avaliada por 2 examinadores independentes de acordo com os critérios modificados de Ryge para cor, descoloração marginal, cárie secundária, forma anatômica, textura de superfície e integridade marginal. Foram realizados, também, testes térmicos de sensibilidade para determinar a resposta pulpar. Para descoloração marginal, o grupo 2 comportou-se melhor que os outros grupos de resinas compostas, mas pior que o grupo do amálgama. Para cárie secundária, forma anatômica, textura de superfície e integridade marginal, nenhuma diferença entre os grupos foi encontrada. Embora, ao término de 2 anos, alguns dentes restaurados tenham permanecido com sensibilidade pulpar (testes térmicos), nenhuma diferença significante foi detetada entre os grupos. Após os 2 anos, a maioria das restaurações apresentavam-se clinicamente aceitáveis. 


\section{PROPOSIÇÃO}

O propósito deste trabalho foi avaliar clinicamente duas resinas

compostas, quanto a:

-sensibilidade pós-operatória,

•forma anatômica,

•cárie secundária,

•integridade marginal,

•descoloração marginal,

$\bullet$ cor,

•influência do período de observação ("baseline”, 6 meses, 1 ano e 2 anos) no

desempenho dos fatores supracitados 
4 MATERIAL E
MÉTODOS 


\section{MATERIAL E MÉTODOS}

Foram selecionados 43 pacientes das Clínicas da Faculdade de Odontologia de Bauru, com base em sua aparente saúde geral, estabilidade geográfica ${ }^{35,178}$, com idades variadas, portadores de pelo menos 2 lesões cariosas proximais sem comprometimento do ângulo incisal e/ou portadores de pelo menos 2 restaurações preexistentes de Classe III, que necessitavam substituição, ou ainda, ambas as condições, localizadas nos dentes anteriores superiores. As razões pelas quais optou-se pela substituição de uma ou mais restaurações foi cárie secundária, perda da restauração, anatomia de superfície pobre ou irregular e descoloração/pigmentação do material restaurador. Preferencialmente, as lesões ou restaurações eram vizinhas ou pelo menos na mesma unidade dentária e com acesso vestibular, podendo ser selecionado, no mínimo um par e no máximo 3 pares de lesões ou restaurações insatisfatórias por paciente.

Selecionado o par, os dentes foram submetidos à uma profilaxia com pedra pomes ${ }^{*}$ e água, a fim de remover quaisquer resíduos ou placa bacteriana que pudesse interferir no processo de seleção de cor. Só então realizou-se a seleção da cor das resinas compostas empregadas. Aplicado o anestésico, instalava-se o isolamento absoluto englobando o maior número de dentes possível, para proporcionar conforto ao paciente e visibilidade ao operador e, ainda, reduzir a contaminação ${ }^{145}$. A abordagem da lesão ou

\footnotetext{
* SS WHITE - ARTIGOS DENTÁRIOS - Rio de Janeiro (RJ) - Brasil.
} 
restauração defeituosa foi feita com brocas esféricas de aço carbide e/ou pontas diamantadas esféricas, em baixa velocidade, com cuidado para não remover estrutura dentária sadia, a partir do centro da lesão/restauração e, dependendo da sua extensão e acesso, utilizou-se alta velocidade na abordagem inicial.

Os preparos cavitários Classe III foram executados sempre aos pares, por um único e mesmo operador, para ter certeza de que o fator pessoal como erro foi minimizado ${ }^{48}$, segundo os princípios recomendados por MONDELLI et al. ${ }^{117}$, com o emprego de pontas diamantadas esféricas ${ }^{*}$ n.1011, 1012, 1013 e 1014, de modo a apenas englobar a lesão ou restauração defeituosa. Quando persistia dentina cariada, esta era removida com brocas de aço, compatíveis com o tamanho da cavidade, em baixa velocidade. $\mathrm{O}$ acabamento das paredes de esmalte foi feito com instrumentos cortantes manuais ${ }^{\dagger}$.

Terminado o preparo cavitário executava-se a proteção do complexo dentinopulpar. Nas cavidades avaliadas como profundas, empregava-se o cimento de hidróxido de cálcio, Dycal ${ }^{\ddagger}$ e o cimento de ionômero de vidro fotopolimerizável Vitrebond $^{\S}$, forrando a parede axial, evitando-se sua extensão vestibular para não ocorrerem interferências na estética final da restauração. Nas cavidades de profundidade média foi acomodado apenas o cimento de ionômero de vidro na parte correspondente ‘a dentina. Os casos em que houve dúvidas quanto ao prognóstico ou a condição pulpar apresentava-se suspeita, foram descartados e encaminhados para a Clínica de Endodontia da Faculdade para avaliações. Retenções adicionais eram realizadas, quando indicadas, com brocas esféricas de

\footnotetext{
* KG SORENSEN - Ind. Com. Ltda. - Barueri (SP) - Brasil.

${ }^{\dagger}$ DUFLEX / SS WHITE ARTIGOS DENTÁRIOS LTDA - Rio de Janeiro (RJ) - Brasil.

* DENTSPLY / CAULK Ind. Com. Ltda. - Petrópolis (RJ) - Brasil - Lote 30290 - Fab. 10/09/96 Val. 10/09/99.

$\S$ 3M DENTAL PRODUCTS - St. Paul (MN) - USA - Lote 19960528 - Val. 05/1999.
} 
aço n.1/2 ou 1/4, em baixa velocidade.

As cavidades foram preparadas e restauradas numa mesma sessão. Em cada paciente, confeccionava-se sempre um par de restaurações, a fim de que as duas resinas compostas comparadas pudessem ser submetidas às mesmas condições clínicas.

Em todos os preparos fazia-se um bisel nas margens com extensão de aproximadamente $1 \mathrm{~mm}$, com as pontas diamantadas ${ }^{*} \mathrm{n} .3118$ e 1111 . Nesta fase, iniciou-se o processo restaurador propriamente dito, o qual será descrito separadamente para cada material restaurador, para melhor entendimento.

\section{Sistema restaurador Magic Adhesiv / Fill Magic - Vigodent:}

Providenciou-se o condicionamento ácido das paredes de esmalte (aproximadamente $1 \mathrm{~mm}$ da superfície externa ao redor da margem cavitária) e/ou dentina com o Magic Acid ${ }^{\dagger}$ com o auxílio de um pincel fino e macio durante 30 segundos, protegendo-se o dente vizinho com uma tira de poliéster ${ }^{\ddagger}$, para que o ácido não o atingisse. $\mathrm{O}$ Magic Acid, segundo o fabricante, é uma solução de ácido fosfórico a 37\%, em forma de gel. Após o condicionamento, lavou-se cuidadosamente com água por 60 segundos e secou-se com jatos de ar livre de óleo e/ou umidade. O fabricante recomenda que não se remova a camada de "smear layer". Nesta fase, foi acomodada uma tira de matriz de poliéster fixada e adaptada com uma cunha refletiva Hawe $\mathrm{Neos}^{\S}$, a fim de proporcionar melhores condições do trabalho de aplicação do sistema adesivo e inserção do material restaurador. A seguir, passouse à aplicação do Magic Adhesiv**, um adesivo fotopolimerizável com liberação de flúor,

\footnotetext{
* KG SORENSEN - Ind. Com. Ltda. - Barueri (SP) - Brasil.

${ }^{\dagger}$ VIGODENT S.A. - Ind. Com. - Rio de Janeiro (RJ) - Brasil - Lote 054906.

* ODAHCAM - HERPO PRODUTOS DENTÁRIOS LTDA - Rio de Janeiro (RJ) - Brasil.

${ }^{\S}$ DFL - Ind. Com. Ltda. - Rio de Janeiro (RJ) - Brasil.

*** VIGODENT S.A. - Ind. Com. - Rio de Janeiro (RJ) - Brasil - Lote 054906.
} 
indicado para dentina e esmalte combinado de duas fases consistentes nos componentes Primer 1, Primer 2 e 1 Adhesiv. O Primer 1 contém, de acordo com o fabricante, ácido orgânico (malêico) 0,02 g, fluoreto de sódio 0,01 g e água 0,97 g. O Primer 2 contém HEMA (Hidroxietilmetacrilato) 0,47 g, HPMA (hidroxipropilmetacrilato) 0,36 g, éster de ácido metacrílico (Polialquenoato metacrilato) 0,06 g e água 0,09 g. O adesivo contém BISGMA 0,43 g, TEGMA 0,48 g e éster de ácido metacrílico (Polialquenoato metacrilato) 0,07 g. Este processo consistia na colocação de 1 gota do Primer 1 com 1 gota do Primer 2 em um casulo, fornecido pelo fabricante, onde misturava-se por aproximadamente 5 segundos e aplicação do Primer misturado na superfície da dentina seca, massageando-a em profundidade durante 30 segundos, eliminando o excesso com o pincel, secando a cavidade com leve jato de ar, livre de água ou óleo. A seguir, o adesivo foi aplicado de forma regular, com outro pincel, sobre as superfícies da dentina e esmalte, por aproximadamente 20 segundos, certificando-se se a área estava completamente seca. Removia-se os excessos e verificava-se se todas as áreas da cavidade estavam cobertas pelo adesivo. A fotopolimerização era feita por 20 segundos com a unidade de luz visível Optilux $150^{*}$. A inserção da resina composta Fill Magic ${ }^{\dagger}$ foi feita em pequenos incrementos, com o auxílio da espátula n.4. As características desse material restaurador, fornecidas pelo fabricante são: compósito microhíbrido, de partículas finas (tamanho médio das partículas $0,5 \mu \mathrm{m}$ ), com alto teor de carga (em média $78 \%$ em peso), radiopaco, fotopolimerizável por luz halógena, com campo de aplicação universal ( dentes anteriores e posteriores), composto de BISGMA, BISEMA, TEGDMA, sílica pirogênica silanizada (sílica coloidal) e silicato de bário e alumínio. Cada incremento, que foi acomodado

\footnotetext{
* DEMETRON (Distribuído pela DFL - Ind. Com. Ltda.) c/ n. de série 1741244.

${ }^{\dagger}$ VIGODENT S.A. - Ind. Com. - Rio de Janeiro (RJ) - Brasil - Lote $054756\left(\right.$ Cores $\left.A_{2}, A_{3}, A_{3,5}, B_{2}\right)$; Lote $054376\left(\right.$ Cor $\left._{2}\right)$; 054366 (Cor B 3 ); Lote 054386 (Cor $\mathrm{D}_{3}$ ).

* THOMPSON DENTAL Mfg. Co. - USA.
} 
na cavidade, recebia uma polimerização inicial através da parede vestibular ou lingual, usando-as como uma interposição para que a intensidade de luz fosse menor nos primeiros segundos, com a mesma unidade de luz visível Optilux 150, a fim de eliminar as tensões geradas pela contração da resina composta. Em seguida, posicionava-se a fonte de luz de maneira que o incremento recebesse, meticulosamente, maior intensidade de luz até completar os 40 segundos. Ao final do processo de inserção foi dada uma carga a mais de fotopolimerização ao redor de toda restauração por questão de segurança. A potência do aparelho de luz ficava em $520 \mathrm{~mW} / \mathrm{cm}^{2}$, a qual era mensurada com um radiômetro ${ }^{*}$, no início de cada sessão clínica.

\section{Sistema restaurador Scotchbond Multi-Purpose Plus / Z-100 - 3M Dental Products.}

Para o uso desse sistema restaurador realizou-se o condicionamento ácido das paredes de esmalte (aproximadamente $1 \mathrm{~mm}$ da superfície externa ao redor da margem cavitária) e/ou dentina com o Scotchbond etchant, aplicado com a própria seringa em que vem acondicionado, durante 15 segundos, protegendo-se o dente vizinho com uma tira de poliéster, para evitar danos ao mesmo. O Scotchbond etchant ${ }^{\dagger}$, segundo o fabricante, é ácido fosfórico a 35\%, em forma de gel. Após o condicionamento, lavou-se cuidadosamente com água por 15 segundos e secou-se com leves jatos de ar livre de óleo e/ou umidade por 5 segundos, removendo a "smear layer" dentinária. Nesta fase, foi acomodada uma tira de matriz de poliéster fixada e adaptada com uma cunha refletiva ${ }^{\ddagger}$, a fim de proporcionar melhores condições do trabalho de aplicação do sistema adesivo e inserção do material

\footnotetext{
* CURING RADIOMETER - DEMETRON RESEARCH Co. - Model 100 P/N 10503 - Serial n. 104873 Danbury - USA.

† 3M DENTAL PRODUCTS - St. Paul (MN) - USA - Lote 19951229.

${ }^{\ddagger}$ DFL - Ind. Com. Ltda. - Rio de Janeiro (RJ) - Brasil.
} 
restaurador. A seguir, passou-se à aplicação do Scotchbond Multi-Purpose Plus ${ }^{*}$, sistema adesivo fotopolimerizável composto de um primer e um adesivo. O Primer contém, de acordo com o fabricante, HEMA (2-Hidroxietilmetacrilato). O adesivo contém BISGMA e HEMA. Após o condicionamento o primer foi aplicado no esmalte e na dentina e seco imediatamente, por 5 segundos, com ar levemente direcionado, o qual estava livre de contaminantes como o óleo ou a água. A cavidade não foi lavada para evitar a retirada desse primer. A superfície de dentina exposta deveria parecer brilhante. Secando levemente verificou-se que isto ocorria com uma única aplicação do mesmo. O primer facilita o molhamento do adesivo na superfície do dente preparado. Na seqüência, o adesivo foi aplicado de forma regular, com um pincel, sobre as superfícies da dentina e esmalte, tomando-se o cuidado de verificar se ele cobria todas as áreas da cavidade. A fotopolimerização era feita por 10 segundos com a unidade de luz visível Optilux 150, já citada anteriormente. A inserção da resina composta Z-100 ${ }^{\dagger}$, foi feita em pequenos incrementos, com o auxílio de uma espátula apropriada identificada anteriormente. A resina Z-100 foi usada como controle, pela sua alta aceitação e utilização pelos profissionais. As características desse material restaurador, fornecidas pelo fabricante são: compósito polimerizável por luz, tamanho máximo de partículas de 4,5 $\mu \mathrm{m}$, zircônia/sílica, representando $71 \%$ em volume, radiopaco, com campo de aplicação em dentes anteriores e posteriores. Parte orgânica composta de BISGMA, TEGDMA. Cada incremento introduzido na cavidade era polimerizado por 40 segundos, da mesma forma que foi descrita para a resina composta Fill Magic, sempre com o mesmo aparelho fotopolimerizador. Convém assinalar que ao final do processo de inserção aplicou-se uma carga a mais de

\footnotetext{
*3M DENTAL PRODUCTS - St. Paul (MN) - USA - Lote 19951229.

${ }^{\dagger}$ 3M DENTAL PRODUCTS - St. Paul (MN) - USA. Importada e distribuída por: 3M DO BRASIL Ltda. PRODUTOS DENTÁRIOS - Sumaré (SP) - Fab. 03/07/96 - Val. 03/07/99 - Lote 6HG (Cores $\mathrm{A}_{2}, \mathrm{~A}_{3}, \mathrm{~A}_{3,5}, \mathrm{~B}_{2}$ ); Lote 6AT (Cor $\left.\mathrm{C}_{4}\right)$; Lote 6EC (Cor $\left.\mathrm{C}_{2}\right)$; Lote 6ED $\left(\mathrm{Cor} \mathrm{B}_{3}\right)$; Lote 6AX $\left(\right.$ Cor $\left.\mathrm{A}_{1}\right)$; Lote 6CR $\left(\mathrm{Cor}_{3}\right)$.
} 
fotopolimerização de 40 segundos ao redor de toda a restauração por questão de segurança.

Os excessos mais grosseiros eram removidos imediatamente após a confecção da restauração empregando lâminas de bisturi* n.11 e 12, tomando o cuidado para não induzir defeitos nas margens.

Tomou-se o cuidado de desenvolver uma ficha clínica especial (Anexo 1), na qual constou os registros de dados pessoais dos pacientes (nome, endereço, telefone, idade e outros informes relevantes), os registros de localização das restaurações (dentes, faces e acesso), data da execução e todos os procedimentos adotados na sua realização (tratamento prévio do dente, material de proteção pulpar, profundidade da cavidade, etc.), os quais eram anotados imediatamente após o término de cada par de restaurações e antes da liberação do paciente. Uma outra ficha (Anexo 2) foi elaborada para que ficassem registradas as avaliações clínicas diretas das restaurações que foram realizadas nas idades previstas, considerando: sensibilidade pós-operatória, forma anatômica, cárie secundária, integridade marginal, descoloração marginal e cor.

O acabamento e polimento das restaurações eram executados após uma semana (7 dias) da inserção do material restaurador na cavidade, pelo emprego de brocas multilaminadas $^{\dagger}$, de 12 e 30 lâminas, utilizadas sob refrigeração; tiras de lixa de polimento e acabamento dental, discos flexíveis Sof-Lex ${ }^{\ddagger}$, e,ainda, o Sistema Enhance ${ }^{\S}$, aplicados de forma intermitente para evitar a geração de calor em excesso.

Nesta sessão (acabamento/polimento) era feita a avaliação inicial

\footnotetext{
* B-D. BECTON DICKINSON - INDÚSTRIAS CIRÚRGICAS LTDA - Juiz de Fora (MG) - Brasil.

${ }^{\dagger}$ JET BRAND (CARBIDE BURS) - n. 7714, 9714, 9642, 9903, 7642 - BEAVERS DENTAL - Morrisburg Ontário - Canadá.

* 3M DO BRASIL Ltda. - Sumaré (SP) - Brasil.

${ }^{\S}$ DENTSPLY Ind. e Com. Ltda. - Petrópolis (RJ) - Brasil..
} 
das restaurações, o "baseline" (primeira avaliação clínica direta), a qual foi realizada por dois avaliadores que foram devidamente treinados e calibrados para tentar alcançar resultados

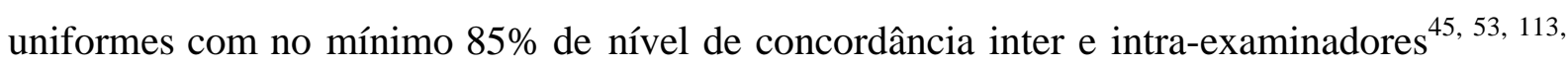
${ }^{148}$, de acordo e obedecendo os critérios preconizados por RYGE ${ }^{149}$. Os examinadores faziam avaliações independentes e quando havia discordância, estas eram refeitas em conjunto, chegando a um consenso, sendo que esta nova avaliação era considerada a definitiva ${ }^{45,53,149}$.

A classificação das restaurações da melhor para a pior era feita clinicamente, analisando o aspecto geral das mesmas. Cada restauração era analisada individualmente. Todas as restaurações receberam avaliação "cega", ou seja, o observador avaliava a qualidade das restaurações sem saber qual resina composta ele estava avaliando, muito menos a técnica de aplicação utilizada ${ }^{45,77}$.

A classificação das restaurações foi feita com base nos escores sugeridos por NAVARRO ${ }^{120}$. Cada item recebia um escore em três níveis, a saber: bom (0), aceitável (1) e inaceitável (2). Somente para o fator cárie é que havia dois níveis: ausente (0) e presente (1). 
Os critérios para a avaliação e classificação da ocorrência de sensibilidade pós-operatória foram:

\begin{tabular}{|ccc|}
\hline CLASSIFICAÇÃO & $\begin{array}{c}\text { CÓDIGO } \\
\text { ESCORE }\end{array}$ & CARACTERÍSTICAS OBSERVADAS \\
ROMEO & $\mathrm{R}=0$ & O paciente não relatou sensibilidade alguma \\
SIERRA & $\mathrm{S}=1$ & $\begin{array}{l}\text { O paciente relatou uma leve sensibilidade, com rápida } \\
\text { resolução } \\
\text { TANGO }\end{array}$ \\
$\mathrm{T}=2$ & $\begin{array}{c}\text { paciente relatou forte sensibilidade, indicando a remoção } \\
\text { da restauração }\end{array}$ \\
\hline
\end{tabular}

Os critérios para a avaliação e classificação da qualidade das restaurações quanto à forma anatômica foram:

\begin{tabular}{|ccc|}
\hline $\begin{array}{c}\text { CLASSIFICAÇÃO } \\
\text { ACEITÁVEL } \\
\text { ROMEO }\end{array}$ & $\begin{array}{c}\text { CÓDIGO } \\
\text { ESCORE }\end{array}$ & $\begin{array}{c}\text { CARACTERÍSTICAS OBSERVADAS } \\
\mathrm{R}=0\end{array}$ \\
$\begin{array}{c}\text { Não há descontinuidade entre o contorno do dente e da } \\
\text { restauração e restabelece a relação de contato }\end{array}$ \\
$\begin{array}{c}\text { SÃO ACEITÁVEL } \\
\text { TANGO }\end{array}$ & $\mathrm{T}=2$ & $\begin{array}{c}\text { A restauração apresenta leve sub ou sobrecontorno, porém } \\
\text { com possibilidade de ajuste e/ou superfícies axiais facetadas } \\
\text { e/ou uma relação de contato levemente aberta }\end{array}$ \\
$\begin{array}{c}\text { A restauração apresenta um sub ou sobrecontorno (sem } \\
\text { possibilidade de ajuste e/ou excessos marginais e/ou } \\
\text { ausência da relação de contato e/ou causa dor e/ou está } \\
\text { ausente }\end{array}$ \\
\hline
\end{tabular}

Os critérios para a avaliação e classificação da qualidade das restaurações quanto à ocorrência de cárie secundária foram:

\begin{tabular}{|ccc|}
\hline $\begin{array}{c}\text { CLASSIFICAÇÃO } \\
\text { ACEITÁVEL } \\
\text { ROMEO }\end{array}$ & $\begin{array}{c}\text { CÓDIGO } \\
\text { ESCORE }\end{array}$ & $\begin{array}{c}\text { CARACTERÍSTICAS OBSERVADAS } \\
\mathrm{R}=0\end{array}$ \\
$\begin{array}{c}\text { Não há evidência de cárie contígua às margens da restauração - } \\
\text { ausência de cárie } \\
\text { VICTOR }\end{array}$ & $\mathrm{V}=1$ & $\begin{array}{l}\text { Existe evidência de cárie nas margens da restauração; o } \\
\text { explorador prende e/ou penetra na margem, observando-se } \\
\text { amolecimento do tecido, ou opacidade indicando desmine- } \\
\text { ralização ou solapamento, mancha esbranquiçada indicando } \\
\text { desmineralização - presença de cárie }\end{array}$ \\
\hline
\end{tabular}


Os critérios para a avaliação e classificação da qualidade das restaurações quanto à integridade marginal foram:

\begin{tabular}{|ccc|}
\hline $\begin{array}{c}\text { CLASSIFICAÇÃO } \\
\text { ACEITÁVEL } \\
\text { ROMEO }\end{array}$ & $\begin{array}{c}\text { CÓDIGO } \\
\text { ESCORE }\end{array}$ & \multicolumn{1}{c|}{ CARACTERÍSTICAS OBSERVADAS } \\
SIERRA & $\mathrm{R}=0$ & $\begin{array}{l}\text { Não há evidência visível de fendas ao longo das margens; } \\
\text { a restauração está em continuidade com o dente; o explora- } \\
\text { dor não é retido quando passado nos dois sentidos (dente - } \\
\text { restauração - dente) }\end{array}$ \\
$\begin{array}{c}\text { NÂO ACEITÁVEL } \\
\text { TANGO }\end{array}$ & $\mathrm{T}=2$ & $\begin{array}{l}\text { Há evidência visível ou perceptível de fenda junto às mar- } \\
\text { gens, porém sem estender-se à junção esmalte-dentina; o } \\
\text { explorador é retido nas margens }\end{array}$ \\
& $\begin{array}{l}\text { Há fenda profunda com a dentina e/ou a base protetora } \\
\text { apresentando-se expostas ao longo da margem e/ou a res- } \\
\text { tauração apresenta mobilidade }\end{array}$ \\
\hline
\end{tabular}

Os critérios para a avaliação e classificação da qualidade das restaurações quanto à descoloração marginal foram:

\begin{tabular}{|c|c|c|}
\hline CLASSIFICAÇÃO & $\begin{array}{l}\text { CÓDIGO } \\
\text { ESCORE }\end{array}$ & CARACTERÍSTICAS OBSERVADAS \\
\hline $\begin{array}{l}\text { ACEITÁVEL } \\
\text { ROMEO }\end{array}$ & $\mathrm{R}=0$ & Nenhuma descoloração nas margens entre a restauração e o dente \\
\hline SIERRA & $S=1$ & $\begin{array}{l}\text { Descoloração presente nas margens entre a restauração e o } \\
\text { dente, porém sem penetração visível }\end{array}$ \\
\hline $\begin{array}{l}\text { NÃO ACEITÁVEL } \\
\text { TANGO }\end{array}$ & $\mathrm{T}=2$ & $\begin{array}{l}\text { Descoloração presente nas margens entre a restauração e o } \\
\text { dente, com visível penetração em direção à polpa }\end{array}$ \\
\hline
\end{tabular}

Os critérios para a avaliação e classificação da qualidade das restaurações quanto à cor foram:

\begin{tabular}{|ccc|}
\hline $\begin{array}{c}\text { CLASSIFICAÇÃO } \\
\text { ACEITÁVEL } \\
\text { ROMEO }\end{array}$ & $\begin{array}{c}\text { CÓDIGO } \\
\text { ESCORE }\end{array}$ & CARACTERÍSTICAS OBSERVADAS \\
SIERRA & $\mathrm{R}=0$ & $\begin{array}{l}\text { Não há desarmonia de cor e/ou translucidez entre a } \\
\text { restauração e o dente }\end{array}$ \\
$\begin{array}{c}\text { NÃO desarmonia entre a restauração e o dente dentro de limites } \\
\text { TANGITÁVEL }\end{array}$ & $\mathrm{T}=2$ & $\begin{array}{l}\text { aceitáveis de cor, matiz e/ou translucência } \\
\text { Hánarmonia entre a restauração e o dente fora de limites } \\
\text { aceitáveis de cor, matiz e/ou translucência - esteticamente } \\
\text { desagradável }\end{array}$ \\
\hline
\end{tabular}


As avaliações clínicas pelo método direto foram feitas no "baseline”, aos 6 meses, 1 ano e aos 2 anos.

Valendo-se de uma sonda exploradora n. $5^{*}$ e espelho bucal n. $5^{\dagger}$, os avaliadores examinaram a forma anatômica e a integridade marginal. Para os critérios cor, descoloração marginal e cárie secundária foi feita a inspeção visual, atribuindo a cada um os escores observados. Para o quesito sensibilidade pós-operatória, a investigação era feita por meio de perguntas direcionadas aos pacientes que relatavam o comportamento das restaurações.

Todas as avaliações foram feitas sob luz natural, no próprio ambiente de trabalho, a uma distância de aproximadamente $0,50 \mathrm{~m}^{43}$. Como medida complementar as restaurações foram fotografadas ${ }^{113}$ utilizando-se uma câmara Pentax K $1000^{\ddagger}$, com objetiva Macro 100 e dois jogos de tubos de extensão, em todos os períodos de observação, imediatamente após os procedimentos de acabamento e polimento (7 dias) e em cada rechamada para as avaliações clínicas diretas (6 meses, 1 ano e 2 anos). Inicialmente foram obtidos diapositivos coloridos com filme Ektachrome - ISO $64^{\S}$ e, a partir desses, fotografias com filmes e papéis $\operatorname{Kodak}^{* *}$, medindo aproximadamente 5,0 x 7,0 cm.

Esses registros fotográficos tinham como objetivo documentar a avaliação, ilustrar o trabalho e/ou contribuir para definir classificações clínicas dúbias e ainda, eventualmente, servirem como meio para avaliação clínica indireta, após serem transformadas em fotografias.

\footnotetext{
* DUFLEX / SS WHITE - ARTIGOS DENTÁRIOS - Rio de Janeiro (RJ) - Brasil.

${ }^{\dagger}$ SS WHITE - ARTIGOS DENTÁRIOS - Rio de Janeiro (RJ) - Brasil.

* ASAHI PENTAX - Manufactured by ASAHI OPTICAL CO. LTD. - Tokyo - Japan.

${ }^{\S}$ EASTMAN KODAK COMPANY - Rochester (NY) - USA.

${ }^{* *}$ EASTMAN KODAK COMPANY - Rochester (NY) - USA.
} 
Além disso, ainda no "baseline", foram selecionados 10 pacientes, dos quais foram obtidas duas moldagens de cada par de restaurações, o que se repetiu a cada rechamada subsequente, para que se pudesse fazer uma análise em Microscópio Eletrônico de Varredura. A primeira moldagem foi desprezada, segundo alguns autores como ABELL; LEINFELDER; TURNER ${ }^{1}$, servindo, esta manobra, como um ato de limpeza para remover todas as películas e resíduos existentes sobre a superfície dentária, a fim de que num segundo tempo se obtivesse uma moldagem perfeita, copiando fielmente os detalhes. Desse modo, o paciente foi solicitado a não fechar a boca entre a primeira e a segunda moldagem. Vazou-se a segunda moldagem com resina epóxica Ortho Bond* para o estudo no MEV. Estas moldagens foram feitas com um material de impressão hidrofílico à base de vinil polisiloxano, Express ${ }^{\dagger}$, com a técnica de 2 passos.

Obtidos os modelos, submetia-se os mesmos ao processo de metalização no aparelho Modelo FL9496 foram cobertos com uma película de ouro de $20 \mathrm{~nm}$, a fim de capacitá-los a conduzir o feixe de elétrons. Utilizou-se o Microscópio Eletrônico de Varredura LEO 430 ${ }^{\S}$, da Disciplina de Patologia Bucal do Departamento de Estomatologia da Faculdade de Odontologia da Universidade de São Paulo, operando a 15 Kv. Para a padronização das imagens, realizou-se, previamente, uma série de fotos, em diferentes aumentos, com a finalidade de um estudo piloto, para que se chegasse a um aumento ideal, que foi de $40 \mathrm{X}$. Este foi assim selecionado, porque permitiu visualização simultânea de todo o material restaurador e da estrutura dental adjacente $^{35}$. Estas imagens foram fotografadas com filme Neopan $\mathrm{SS}^{* *}$, auxiliando na

\footnotetext{
* VERNON-BENSHOFF CO., INC. - Albany (NY) - USA.

${ }^{\dagger}$ 3M DENTAL PRODUCTS - St. Paul (MN) - USA - Lote 19960710.

* BALZERS UNION (BALZERS / FÜRSTENTUM LIECHTENSTEIN).

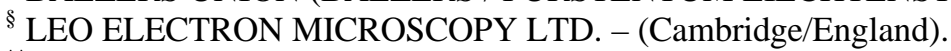

${ }^{* * *}$ FUJI PHOTO FILM CO. LTD. - Tokyo - Japan.
} 
ilustração do trabalho, com visualização da perda ou não da forma anatômica e/ou da integridade marginal.

Todos os pacientes foram informados e esclarecidos sobre o fato de estarem participando de um trabalho de pesquisa clínica. Sendo assim, foi elaborado um documento (Anexos 3 e 4), no qual os pacientes participantes declaravam estar cientes e concordantes nessa participação, submetendo-se às sessões de avaliação clínica nos períodos estabelecidos $^{35}$

Embora insistentemente solicitados, muitos pacientes deixaram de comparecer às avaliações periódicas. Muitos, no entanto, foram procurados até domiciliarmente, num esforço para reunir todos os pacientes envolvidos nesta pesquisa. Do total de 43 pacientes, 8 não foram localizados, assim 8 conjuntos ou 16 restaurações foram forçosamente excluídas do trabalho. Como em cada paciente avaliou-se 2 restaurações, um total de 70 foram consideradas.

Os dados coletados foram tabelados e analisados estatisticamente empregando-se o teste exato de Fisher. 
5 RESULTADOS 


\section{RESULTADOS}

Os resultados conseguidos relativos à avaliação clínica das resinas compostas Z-100 e Fill Magic, em dentes anteriores, serão apresentados neste capítulo. Para maior facilidade e visualização dos mesmos foram elaboradas as Tabelas 5.1, 5.2, 5.3 e 5.4, com as quantidades de escores atribuídos aos diversos fatores analisados, nos diferentes períodos de observação.

TABELA 5.1 - Resultados obtidos no "baseline"

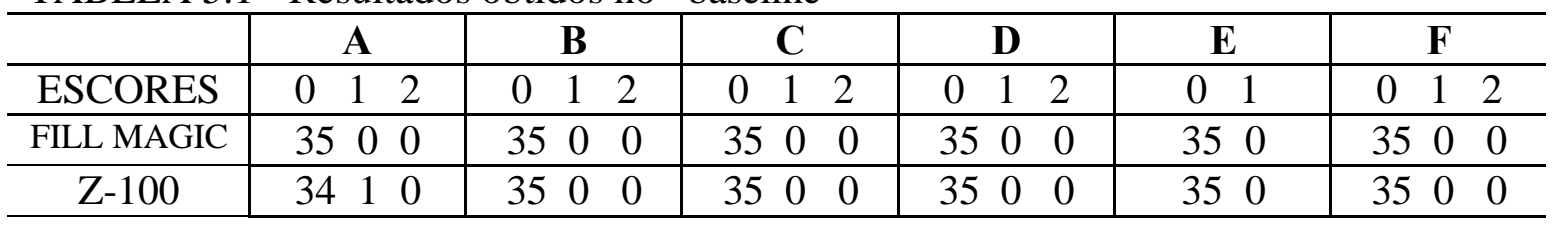

TABELA 5.2 - Resultados obtidos na avaliação de 6 meses

\begin{tabular}{c|ccc|ccc|ccc|ccc|cc|ccc}
\hline & \multicolumn{3}{|c|}{$\mathbf{A}$} & \multicolumn{3}{|c|}{$\mathbf{B}$} & \multicolumn{3}{|c|}{$\mathbf{C}$} & \multicolumn{3}{|c|}{$\mathbf{D}$} & \multicolumn{3}{|c|}{$\mathbf{E}$} & \multicolumn{3}{|c}{ F } \\
\hline ESCORES & 0 & 1 & 2 & 0 & 1 & 2 & 0 & 1 & 2 & 0 & 1 & 2 & 0 & 1 & 0 & 1 & 2 \\
\hline FILL MAGIC & 35 & 0 & 0 & 35 & 0 & 0 & 35 & 0 & 0 & 35 & 0 & 0 & 35 & 0 & 35 & 0 & 0 \\
\hline Z-100 & 31 & 4 & 0 & 35 & 0 & 0 & 35 & 0 & 0 & 35 & 0 & 0 & 35 & 0 & 35 & 0 & 0 \\
\hline
\end{tabular}

TABELA 5.3 - Resultados obtidos na avaliação de 1 ano

\begin{tabular}{c|ccc|ccc|ccc|ccc|cc|ccc}
\hline & \multicolumn{3}{|c|}{$\mathbf{A}$} & \multicolumn{3}{|c|}{$\mathbf{B}$} & \multicolumn{3}{|c|}{$\mathbf{C}$} & \multicolumn{3}{|c|}{$\mathbf{D}$} & \multicolumn{3}{|c|}{ E } & \multicolumn{3}{|c}{ F } \\
\hline ESCORES & 0 & 1 & 2 & 0 & 1 & 2 & 0 & 1 & 2 & 0 & 1 & 2 & 0 & 1 & 0 & 1 & 2 \\
\hline FILL MAGIC & 34 & 1 & 0 & 35 & 0 & 0 & 35 & 0 & 0 & 35 & 0 & 0 & 35 & 0 & 35 & 0 & 0 \\
\hline Z-100 & 31 & 4 & 0 & 35 & 0 & 0 & 35 & 0 & 0 & 35 & 0 & 0 & 35 & 0 & 35 & 0 & 0 \\
\hline
\end{tabular}

TABELA 5.4 - Resultados obtidos na avaliação de 2 anos

\begin{tabular}{c|ccc|ccc|ccc|ccc|cc|ccc}
\hline & \multicolumn{3}{|c|}{$\mathbf{A}$} & \multicolumn{3}{|c|}{$\mathbf{B}$} & \multicolumn{3}{|c|}{$\mathbf{C}$} & \multicolumn{3}{|c|}{$\mathbf{D}$} & \multicolumn{3}{|c|}{$\mathbf{E}$} & \multicolumn{3}{|c}{ F } \\
\hline ESCORES & 0 & 1 & 2 & 0 & 1 & 2 & 0 & 1 & 2 & 0 & 1 & 2 & 0 & 1 & 0 & 1 & 2 \\
\hline FILL MAGIC & 34 & 1 & 0 & 35 & 0 & 0 & 35 & 0 & 0 & 35 & 0 & 0 & 35 & 0 & 35 & 0 & 0 \\
\hline Z-100 & 32 & 3 & 0 & 35 & 0 & 0 & 35 & 0 & 0 & 35 & 0 & 0 & 35 & 0 & 35 & 0 & 0 \\
\hline
\end{tabular}


Legenda:

A - cor

B - descoloração marginal

C - forma anatômica

D - integridade marginal

E - cárie secundária

F - sensibilidade pós-operatória

A Figura 5.1 ilustra uma sequência de fotos, de um paciente, durante a avaliação ("baseline”, 6 meses, 1 ano e 2 anos), onde não houve alteração alguma. A Figura 5.2 ilustra, também, uma sequência de fotos, porém com mudanças na cor em uma das resinas compostas, único fator a sofrer alteração durante o período de acompanhamento. 

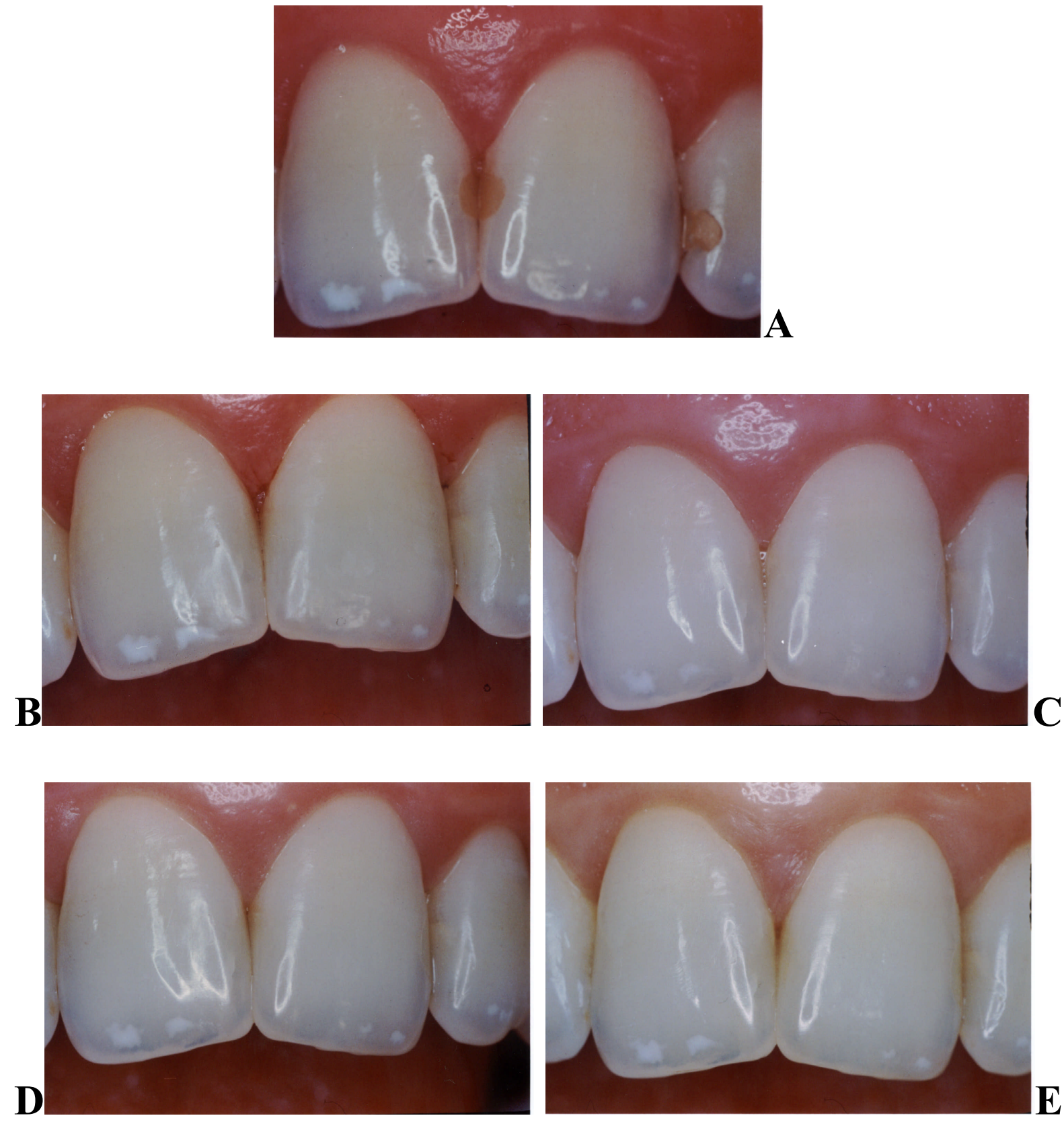

Figura 5.1 - Aspecto do conjunto de restaurações em diferentes períodos de tempo. A restauração na mesial do dente 11 foi feita com a resina composta Z-100 e na mesial do dente 21, com Fill Magic. Não foi anotada alteração de cor nas restaurações. A - Inicial; B - "Baseline"; C - 6 meses; D - 1 ano; E - 2 anos. 

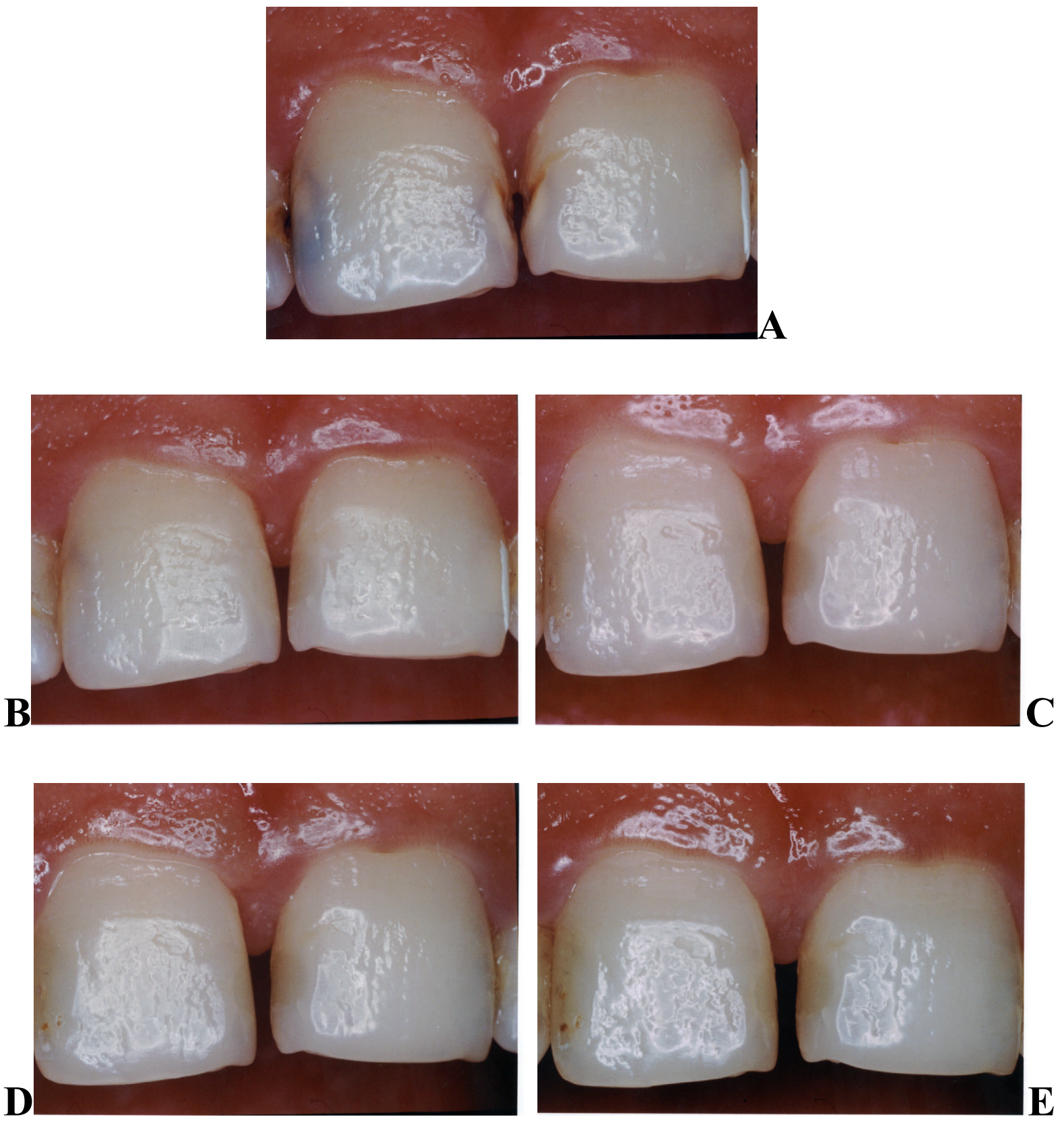

Figura 5.2 - Aspecto do conjunto de restaurações em diferentes períodos de tempo. A restauração na mesial do dente 11 foi feita com a resina composta Fill Magic e na mesial do dente 21, com Z-100. Foi anotada alteração de cor na restauração do dente 21, já aos 6 meses de avaliação. A - Inicial; B - "Baseline"; C - 6 meses; D - 1 ano; E - 2 anos. 
Ambos os materiais, neste estudo, comportaram-se bem clinicamente no período de 2 anos e nenhuma restauração foi substituída devido à falhas dos mesmos (Tabelas 5.5 e 5.6).

TABELA 5.5 - Histórico das restaurações com resina composta Fill Magic no período de 2 anos

\begin{tabular}{c|c|c|c|c|c}
\hline & Avaliadas & $\begin{array}{c}\text { Perda da } \\
\text { restauração }\end{array}$ & $\begin{array}{c}\text { perdidas } \\
\text { devido não } \\
\text { retorno do } \\
\text { paciente }\end{array}$ & $\begin{array}{c}\text { Substituídas } \\
\text { (inaceitáveis } \\
\text {-escore 2) }\end{array}$ & $\begin{array}{c}\text { Perda } \\
\text { Do } \\
\text { Dente }\end{array}$ \\
\hline "baseline" & 43 & 00 & 00 & 00 & 00 \\
\hline 6 meses & 40 & 00 & 03 & 00 & 00 \\
\hline 1 ano & 35 & 00 & 08 & 00 & 00 \\
\hline 2 anos & 35 & 00 & 08 & 00 & 00 \\
\hline
\end{tabular}

TABELA 5.6 - Histórico das restaurações com resina composta Z-100 no período de 2 anos

\begin{tabular}{c|c|c|c|c|c}
\hline & Avaliadas & $\begin{array}{c}\text { Perda da } \\
\text { restauração }\end{array}$ & $\begin{array}{c}\text { perdidas } \\
\text { devido não } \\
\text { retorno do } \\
\text { paciente }\end{array}$ & $\begin{array}{c}\text { Substituídas } \\
\text { (inaceitáveis } \\
\text {-escore 2) }\end{array}$ & $\begin{array}{c}\text { Perda } \\
\text { Do } \\
\text { Dente }\end{array}$ \\
\hline "baseline" & 43 & 00 & 00 & 00 & 00 \\
\hline 6 meses & 40 & 00 & 03 & 00 & 00 \\
\hline 1 ano & 35 & 00 & 08 & 00 & 00 \\
\hline 2 anos & 35 & 00 & 08 & 00 & 00 \\
\hline
\end{tabular}

Sensibilidade pós-operatória, forma anatômica, cárie secundária, integridade marginal e descoloração marginal permaneceram sem alteração durante os 2 anos, pois todos os itens receberam escores zero (Tabelas 5.7 e 5.8). Entretanto, a cor de algumas restaurações sofreu mudanças com o passar do tempo (Tabelas 5.7, 5.8, 5.9 e Figuras 5.3 a 5.10)

Durante o estudo, nos primeiros 6 meses, 6 restaurações não puderam ser acompanhadas porque 3 pacientes não retornaram, apesar de todo o esforço feito, com visitas aos domicílios dos mesmos, nos quais constatou-se que haviam se mudado, sem 
deixar referências para contato. Posteriormente, mais 5 pacientes tiveram que ser excluídos do trabalho, pelo mesmo motivo já citado, prejudicando a observação de mais 10 restaurações (Tabelas 5.5 e 5.6). Deve-se salientar, a bem da verdade, que foram confeccionados, por uma questão humanitária, mais restaurações do que as necessárias para efeito da pesquisa.

Devido ao fato do paciente estar anestesiado e com o isolamento absoluto instalado, optava-se por restaurar todos os dentes ântero-superiores que apresentassem cáries ou restaurações insatisfatórias. Quando se realizava 3 restaurações contígüas num mesmo paciente (duas com um material e uma com outro), para não prejudicar ou beneficiar uma das resinas, optou-se por utilizar para o acompanhamento, somente um par de restaurações (com resinas diferentes) para cada paciente, escolhidas por sorteio.

TABELA 5.7 - Restaurações com resina composta Fill Magic avaliadas $(n=35)$

\begin{tabular}{|c|c|c|c|c|c|c|c|c|c|c|c|c|}
\hline \multirow[b]{2}{*}{ Categoria } & \multicolumn{4}{|c|}{ Escore 0} & \multicolumn{4}{|c|}{ Escore 1} & \multicolumn{4}{|c|}{ Escore 2} \\
\hline & $\mathbf{B}$ & $6 \mathrm{~m}$ & $1 \mathbf{a}$ & $2 \mathbf{a}$ & $\mathbf{B}$ & $6 \mathrm{~m}$ & $1 \mathbf{a}$ & $2 \mathbf{a}$ & $\mathbf{B}$ & $6 \mathrm{~m}$ & $1 \mathbf{a}$ & $2 \mathrm{a}$ \\
\hline Cor & 35 & 35 & 34 & 34 & 00 & 00 & 01 & 01 & 00 & 00 & 00 & 00 \\
\hline $\begin{array}{c}\text { Descoloração } \\
\text { marginal }\end{array}$ & 35 & 35 & 35 & 35 & 00 & 00 & 00 & 00 & 00 & 00 & 00 & 00 \\
\hline Forma antômica & 35 & 35 & 35 & 35 & 00 & 00 & 00 & 00 & 00 & 00 & 00 & 00 \\
\hline Integridade marginal & 35 & 35 & 35 & 35 & 00 & 00 & 00 & 00 & 00 & 00 & 00 & 00 \\
\hline Cárie secundária & 35 & 35 & 35 & 35 & 00 & 00 & 00 & 00 & & & & \\
\hline $\begin{array}{l}\text { Sensibilidade pós- } \\
\text { operatória }\end{array}$ & 35 & 35 & 35 & 35 & 00 & 00 & 00 & 00 & 00 & 00 & 00 & 00 \\
\hline
\end{tabular}


TABELA 5.8 - Restaurações com resina composta Z-100 avaliadas ( $\mathrm{n}=35$ )

\begin{tabular}{|c|c|c|c|c|c|c|c|c|c|c|c|c|}
\hline \multirow[b]{2}{*}{ Categoria } & \multicolumn{4}{|c|}{ Escore 0} & \multicolumn{4}{|c|}{ Escore 1} & \multicolumn{4}{|c|}{ Escore 2} \\
\hline & B & $6 \mathrm{~m}$ & $1 \mathbf{a}$ & $2 \mathbf{a}$ & $\mathbf{B}$ & $6 \mathrm{~m}$ & $1 \mathbf{a}$ & $2 \mathbf{a}$ & $\mathbf{B}$ & $6 \mathrm{~m}$ & $1 \mathbf{a}$ & $2 \mathbf{a}$ \\
\hline Cor & 34 & 31 & 31 & 32 & 01 & 04 & 04 & 03 & 00 & 00 & 00 & 00 \\
\hline $\begin{array}{c}\text { Descoloração } \\
\text { marginal }\end{array}$ & 35 & 35 & 35 & 35 & 00 & 00 & 00 & 00 & 00 & 00 & 00 & 00 \\
\hline Forma antômica & 35 & 35 & 35 & 35 & 00 & 00 & 00 & 00 & 00 & 00 & 00 & 00 \\
\hline Integridade marginal & 35 & 35 & 35 & 35 & 00 & 00 & 00 & 00 & 00 & 00 & 00 & 00 \\
\hline Cárie secundária & 35 & 35 & 35 & 35 & 00 & 00 & 00 & 00 & & & & \\
\hline $\begin{array}{c}\text { Sensibilidade pós- } \\
\text { operatória }\end{array}$ & 35 & 35 & 35 & 35 & 00 & 00 & 00 & 00 & 00 & 00 & 00 & 00 \\
\hline
\end{tabular}

Legenda:

B - "Baseline"

$6 \mathbf{m}-6$ meses

$1 \mathbf{a}-1$ ano

$\mathbf{2} \mathbf{a}-2$ anos

A Tabela 5.9 apresenta um resumo do comportamento das restaurações com relação à cor no "baseline", aos 6 meses, 1 ano e aos 2 anos, com as respectivas porcentagens.

TABELA 5.9 - Comportamento das restaurações com relação à cor

\begin{tabular}{lcccccccccccc}
\hline & \multicolumn{3}{c}{ "BASELINE" } & \multicolumn{3}{c}{ 6 MESES } & \multicolumn{3}{c}{ 1 ANO } & \multicolumn{3}{c}{ ANOS } \\
ESCORES & 0 & 1 & 2 & 0 & 1 & 2 & 0 & 1 & 2 & 0 & 1 & 2 \\
MATERIAL & & & & & & & & & & & \\
\hline Fill Magic & 35 & 0 & 0 & 35 & 0 & 0 & 34 & 1 & 0 & 34 & 1 & 0 \\
Porcentagens & 100,0 & 0 & 0 & 100,0 & 0 & 0 & 97,1 & 2,9 & 0 & 97,1 & 2,9 & 0 \\
\hline Z-100 & 34 & 1 & 0 & 31 & 4 & 0 & 31 & 4 & 0 & 32 & 3 & 0 \\
Porcentagens & 97,1 & 2,9 & 0 & 88,6 & 11,4 & 0 & 88,6 & 11,4 & 0 & 91,4 & 8,6 & 0 \\
\hline Teste de Fisher $(\mathrm{p})$ & $\mathrm{p}=1,000$ & n.s. & $\mathrm{p}=0,114$ & n.s. & $\mathrm{p}=0,357$ & n.s. & $\mathrm{p}=0,614$ n.s. \\
\hline
\end{tabular}

n.s. : associação estatisticamente não significante

Considerando que para os critérios de sensibilidade pós-operatória, forma anatômica, cárie secundária, integridade marginal e descoloração marginal não houve nenhuma alteração nas avaliações "baseline", 6 meses, 1 ano e 2 anos e tendo em vista que o 
único critério que variou nesses exames foi a cor, a seguir é feita uma análise desse item (Tabela 5.9).

No "baseline", das 70 restaurações verificou-se que as 35 (100\%) realizadas com a resina composta Fill Magic receberam escores zero. Quanto as 35 com a Z100, uma $(2,9 \%)$ restauração recebeu escore 1 e as demais $(97,1 \%)$ receberam escores zero.

No retorno dos 6 meses, foram avaliados o mesmo total de restaurações e para as $35(100 \%)$ da Fill Magic atribuíram-se escores zero, enquanto para a resina Z-100, $31(88,6 \%)$ receberam escores zero e quatro $(11,4 \%)$ escores 1.

Na avaliação de 1 ano, as porcentagens repetiram-se para a Z-100. Já para a Fill Magic, somente 1 restauração $(2,9 \%)$ recebeu escore 1 e as demais $34(97,1 \%)$ escores zero.

Aos 2 anos, repetiram-se as porcentagens para a resina Fill Magic. Para a Z-100, 32 restaurações $(91,4 \%)$ foram consideradas escores zero e $3(8,6 \%)$ levaram o escore 1.

Nenhum escore 2 foi anotado para qualquer item avaliado, durante os períodos de observações.

Os resultados foram analisados estatisticamente pelo teste exato de Fisher e nenhuma diferença significante foi observada entre as duas resinas compostas comparadas, aceitando-se, assim, a hipótese de igualdade entre as mesmas. 


\section{$\underline{\text { ESCORES }}$}

0 ("zero") = Não há desarmonia de cor e/ou translucidez entre a restauração e o dente

1 ("um") = Há desarmonia entre a restauração e o dente dentro de limites aceitáveis de cor, matiz e/ou translucência.

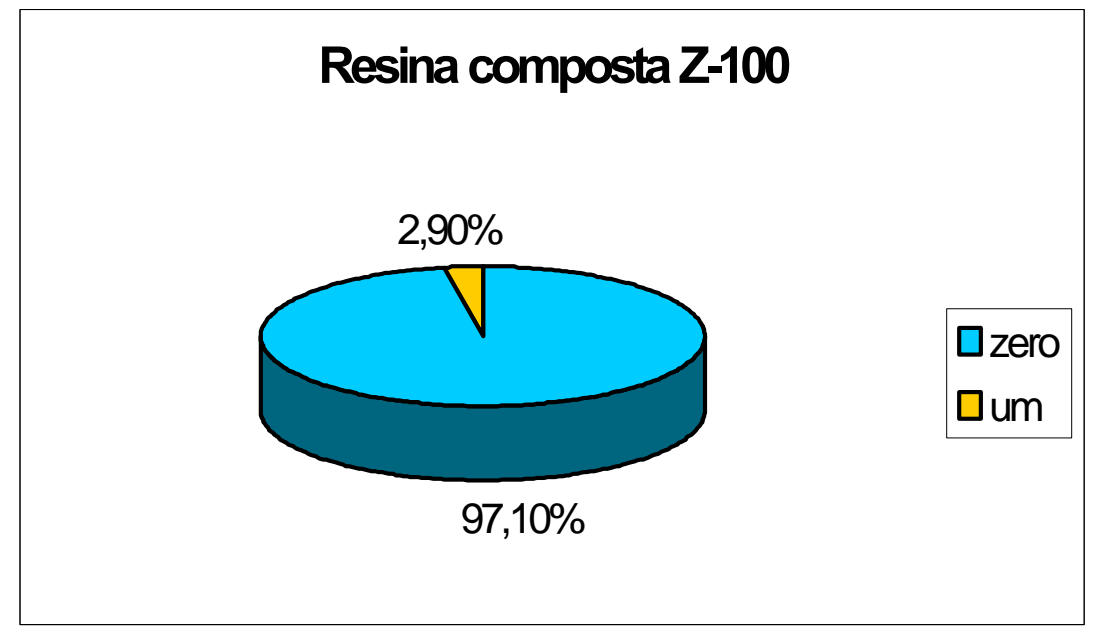

Figura 5.3 - Gráfico representativo das porcentagens de alteração de cor, no "baseline”, para a resina composta Z-100

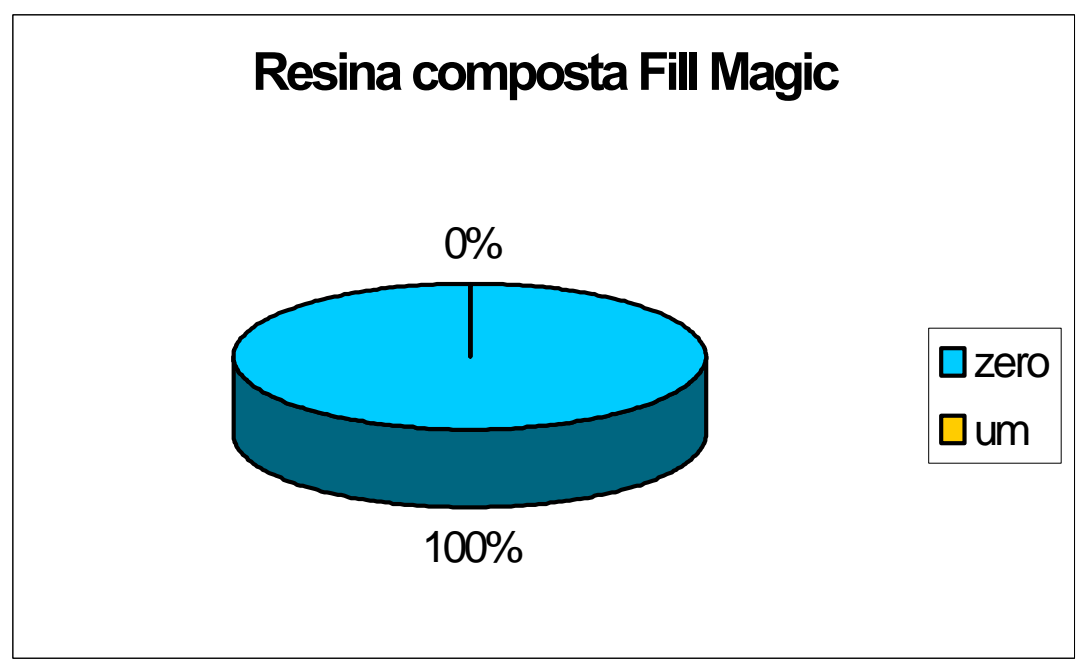

Figura 5.4 - Gráfico representativo das porcentagens de alteração de cor, no "baseline”, para a resina composta Fill Magic 


\section{$\underline{\text { ESCORES }}$}

0 (“zero") = Não há desarmonia de cor e/ou translucidez entre a restauração e o dente

1 ("um”) = Há desarmonia entre a restauração e o dente dentro de limites aceitáveis de cor, matiz e/ou translucência.

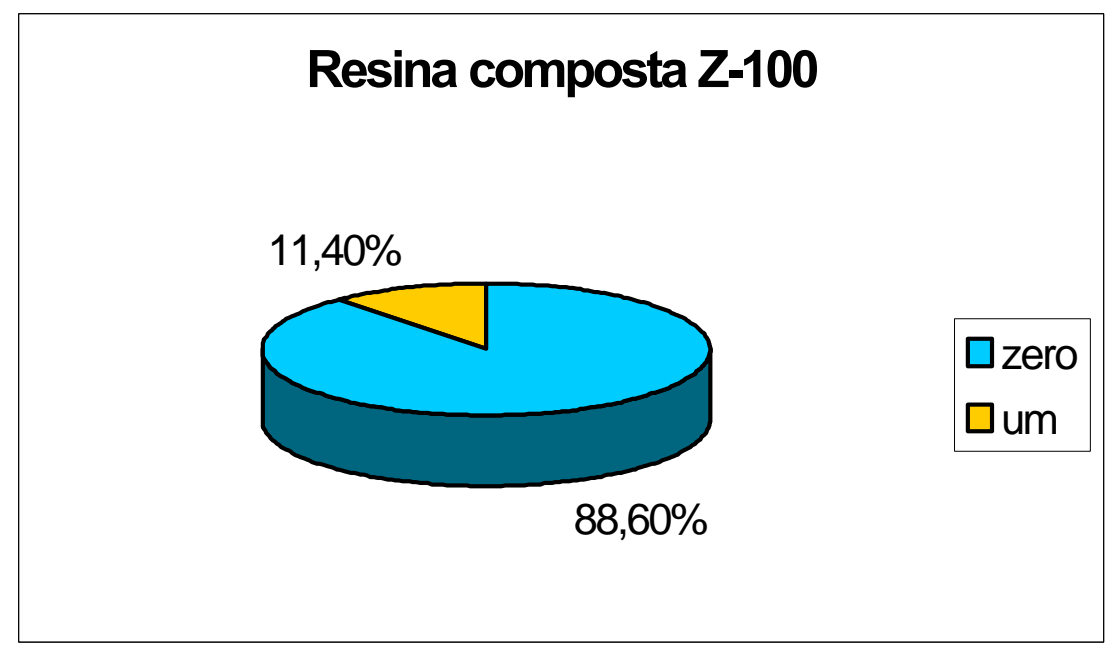

Figura 5.5 - Gráfico representativo das porcentagens de alteração de cor, na avaliação de 6 meses, para a resina composta Z-100

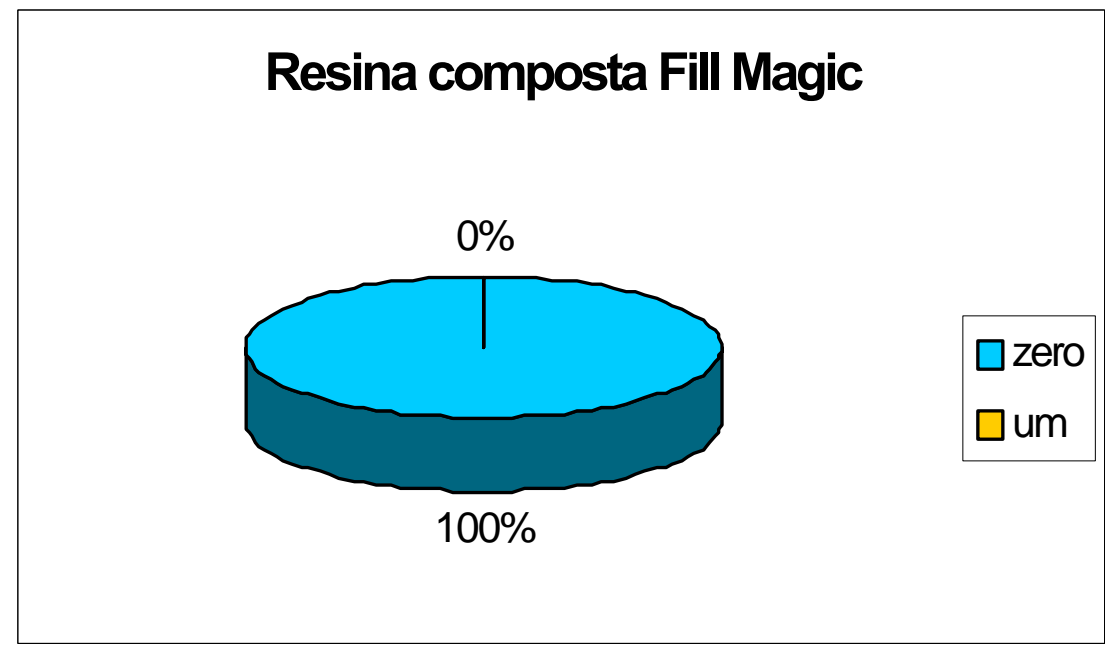

Figura 5.6 - Gráfico representativo das porcentagens de alteração de cor, na avaliação de 6 meses, para a resina composta Fill Magic 


\section{$\underline{\text { ESCORES }}$}

0 ("zero") = Não há desarmonia de cor e/ou translucidez entre a restauração e o dente

1 ("um”) = Há desarmonia entre a restauração e o dente dentro de limites aceitáveis de cor, matiz e/ou translucência.

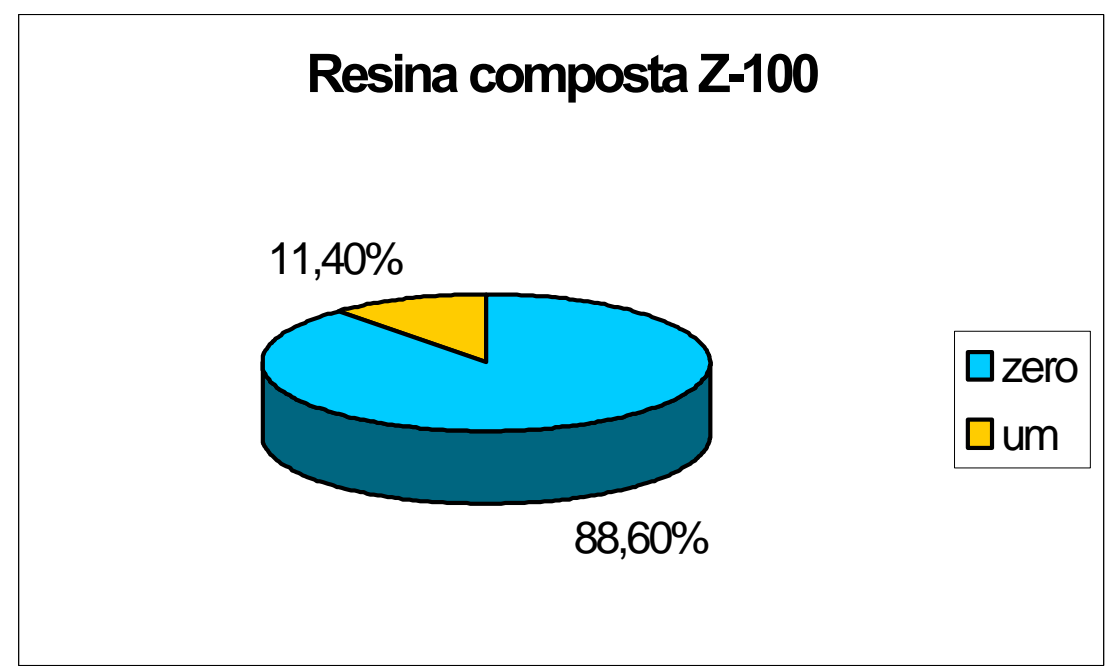

Figura 5.7 - Gráfico representativo das porcentagens de alteração de cor, na avaliação de 1 ano, para a resina composta $\mathrm{Z}-100$

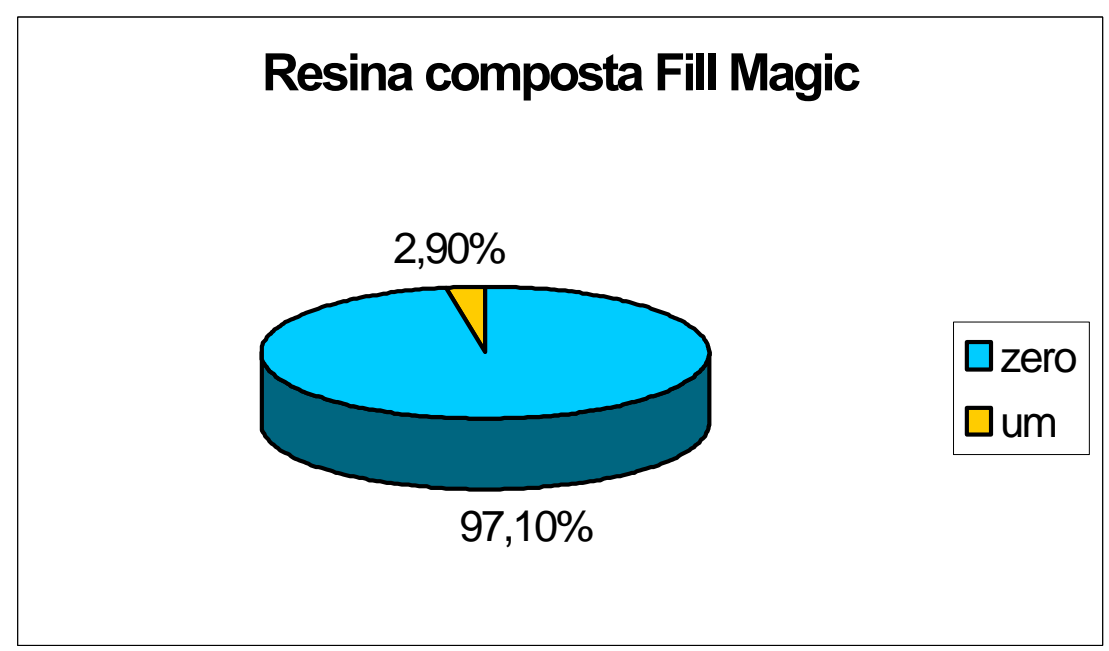

Figura 5.8 - Gráfico representativo das porcentagens de alteração de cor, na avaliação de 1 ano, para a resina composta Fill Magic 


\section{ESCORES}

0 ("zero") = Não há desarmonia de cor e/ou translucidez entre a restauração e o dente

1 ("um”) = Há desarmonia entre a restauração e o dente dentro de limites aceitáveis de cor, matiz e/ou translucência.

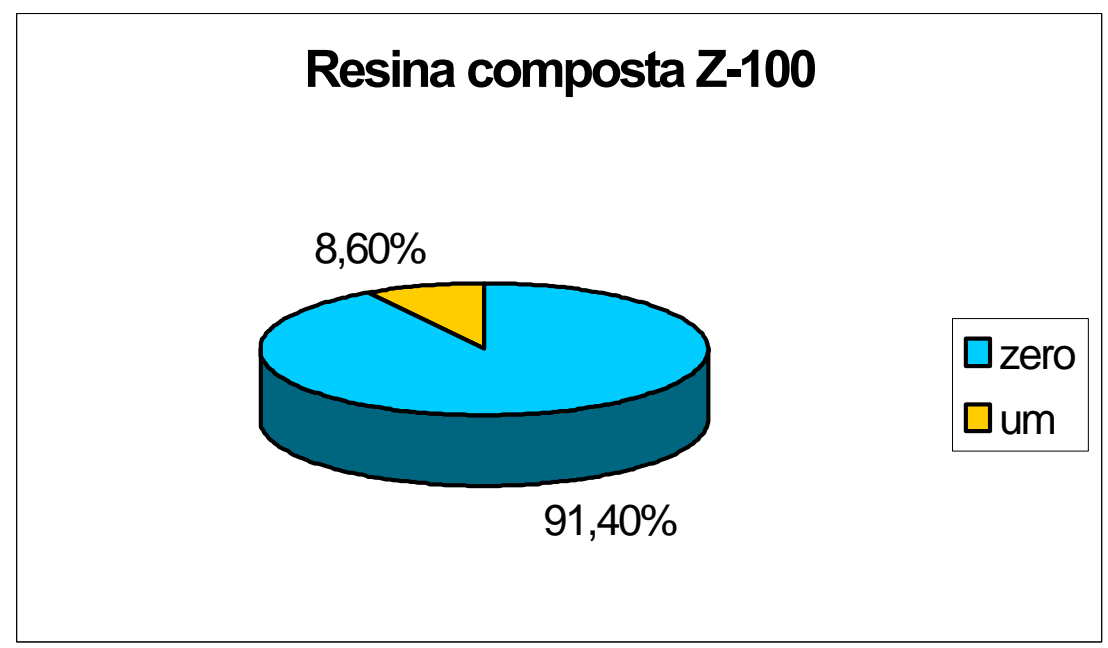

Figura 5.9 - Gráfico representativo das porcentagens de alteração de cor, na avaliação de 2 anos, para a resina composta Z-100

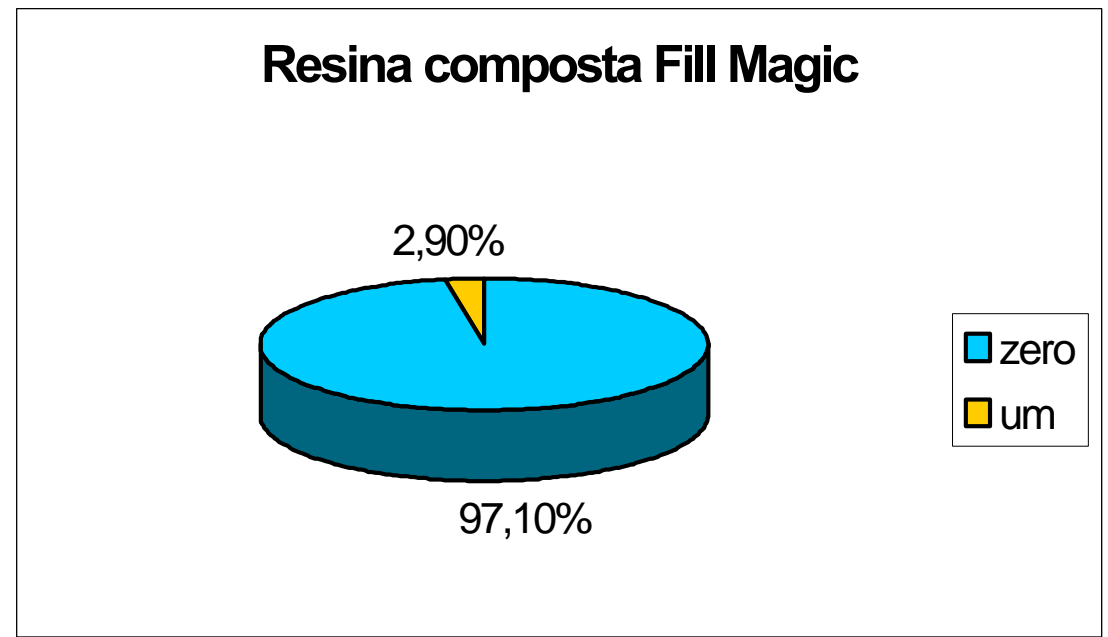

Figura 5.10 - Gráfico representativo das porcentagens de alteração de cor, na avaliação de 2 anos, para a resina composta Fill Magic 
6 DISCUSSÃO 


\section{DISCUSSÃO}

As pesquisas clínicas têm mostrado grandes discrepâncias relacionadas com as metodologias utilizadas pelos diversos autores, corroborada pela dificuldade de padronização das técnicas, pela aplicação de diferentes períodos de observações e também pelos critérios de avaliação postos em prática.

A apreciação da literatura correlata revela as inúmeras metodologias adotadas para trabalhos clínicos, notando-se os mais variados métodos para a consecução das respectivas pesquisas. Apesar do tempo decorrido desde a publicação de alguns desses trabalhos, trata-se de um legado importante, que não deve e nem pode, de maneira alguma, ser postergado. Pelo contrário, ao longo dos anos, esses métodos de observações clínicas têm recebido adaptações e incrementações, permitindo que a fundamentação básica permanecesse como um paradigma de valor inestimável. Algumas metodologias freqüentemente usadas e seus autores que, por meio de pesquisas e publicações, deixaram registrados elementos fundamentais que são de grande valia para as pesquisas clínicas atuais.

No intuito de facilitar a compreensão da discussão do presente trabalho, procurou-se ordenar os assuntos numa sequiência que permitisse um melhor acompanhamento com relação à metodologia adotada, sensibilidade pós-operatória, forma anatômica, cárie secundária, integridade marginal/descoloração marginal e cor. 


\subsection{METODOLOGIA}

O método utilizado neste trabalho foi justamente o de Ryge, citado páginas à frente, com algumas modificações feitas por NAVARRO ${ }^{120}$. Embora seja subjetiva optou-se por esta metodologia pela sua abrangência, de forma a envolver amplamente os aspectos inerentes a serem investigados, além de ser de fácil execução e exigir menor custo operacional. Com uma padronização criteriosa e um rigor acentuado dos avaliadores, consegue-se resultados confiáveis. Outras metodologias são limitadas, restringindo-se a verificar poucos aspectos comportamentais, além de não permitir um estudo global das restaurações a serem avaliadas. Um exemplo seria a utilização da microscopia eletrônica de varredura, que impossibilita observar as mudanças na cor da resina composta ou de aparelhos para avaliar alteração de cor, que não propiciam identificar mudanças na forma e integridade marginal.

No intuito de verificar se os resultados clínicos estavam de acordo com as observações laboratoriais, PAFFENBARGER ${ }^{129}$, em 1940, trabalhando com cimento de silicato, realizou experimentos e idealizou questionários que foram enviados aos membros da Comissão de Pesquisa da American Dental Association e do National Bureau of Standards. Os quesitos arguiíam quais cimentos eram preferidos, que propriedades os profissionais consideravam significativas do ponto de vista clínico e quais procedimentos manipulativos usados poderiam ser de ajuda no preparo de uma especificação para o material.

O método de se escolher 4 restaurações que apresentavam 4 graus de falhas clínicas (mínima, leve, moderada e severa) das quais foram tomadas fotografiaspadrão, que por sua vez eram classificadas em 5 categorias, conforme o grau de alteração, para investigar degradação marginal e perda superficial foi escolhido por MITCHEM ${ }^{114}$ para 
seus estudos. Por outro lado, com a finalidade de avaliar a integridade marginal das restaurações estéticas utilizando o "ranking" fotográfico, GALAN JUNIOR et al. ${ }^{67}$ verificaram que essa metodologia tem suas limitações, não se prestando para investigação do perfil de desgaste (forma anatômica) e os autores sugerem que o mesmo seja combinado com o método clínico direto com sonda exploradora e espelho bucal. Da mesma forma, utilizando o registro fotográfico das restaurações, com o objetivo de comparar os dados observados, WILSON; RYGE ${ }^{198}$ fizeram seus estudos. Também o registro de fotografias, obtidas em preto e branco, para classificação das discrepâncias marginais de restaurações a amálgama foi preconizado por MAHLER et al. ${ }^{105}$.

Usando os critérios desenvolvidos por Cvar; Ryge, LEINFELDER et al. ${ }^{102}$ conduziram uma avaliação clínica analisando materiais restauradores anteriores e posteriores para verificar cor, desgaste, adaptação marginal, descoloração marginal e cárie secundária. Em outro trabalho, LEINFELDER; SLUDER; SANTOS ${ }^{101}$ fizeram uso do mesmo método de avaliação (o sistema Ryge) e ainda fotografias e microscopia eletrônica de varredura, para observações clínicas. DAVIS; MAYHEW ${ }^{45}$ também usaram o sistema Ryge. SELA et al. ${ }^{154}$ para estudar adaptação marginal das restaurações usaram réplicas que eram levadas ao MEV. FLYNN ${ }^{61,62}$ para avaliar estabilidade marginal e resistência ao desgaste também fez uso do MEV. OSBORNE et al. ${ }^{127}$ investigaram fratura marginal das restaurações à amálgama por meio de fotografias ordenadas da melhor para a pior. SANTOS; RIBEIRO; STEAGALL ${ }^{153}$, com um explorador e uma lupa examinavam as restaurações e atribuíam escores: +++ ótimo, ++ bom, + regular e - mau.

Para avaliar cor das resinas compostas in vivo pode-se usar um método objetivo de medição pelo colorímetro, aparelho que mede quantitativamente a cor das 
superfícies das restaurações. Apesar do alto custo do aparelho, da dificuldade de obtenção e de limitar-se somente àquela finalidade, este processo foi utilizado por BAUSCH et al. ${ }^{11}$.

SMALES $^{161}$ observou as características clínicas das restaurações e as classificava em 3 grupos: boa, adequada (aceitável, mas não ideal) e insatisfatória.

Grandes nomes no campo da pesquisa clínica, como RYGE; SNYDER $^{148}$ (1973), introduziram métodos de avaliação, nos quais estudiosos e pesquisadores baseiam-se ou utilizam-nos até hoje. Num desses processos pode-se evidenciar trabalhos de campo observando restaurações, as quais eram classificadas em: "satisfatória" ou "não aceitável". Consideravam-se 2 ítens na categoria satisfatória, que eram: "está de acordo com os padrões" e "observe na próxima visita". Na categoria "não aceitável”, 2 quesitos eram observados: "substituir por prevenção" e "necessidade de substituição". Um critério específico com palavras-chave correspondentes foi desenvolvido para cada uma das 4 categorias com relação a 3 características: superfície e cor, forma anatômica e integridade marginal. O sistema permite ser usado por examinadores treinados para avaliar qualidade de restaurações feitas por Cirurgiões-Dentistas ou por auxiliares odontológicas tanto em clínicas privadas como em programas públicos.

RYGE, agora com CVAR ${ }^{43}$ (1973), elabora uma metodologia, com escalas de avaliação para cor, descoloração marginal, forma anatômica, adaptação marginal e cárie. Códigos Alfa (A), Bravo (B), Charlie (C) ou Delta (D), dependendo do que era avaliado, eram empregados para expressar o aspecto da restauração no momento em que ela estava sendo examinada. Para descoloração marginal, por exemplo, as categorias eram as seguintes: Alfa - código A - não há nenhuma descoloração na margem entre a restauração e a estrutura dentária; Bravo - código B - existe alguma descoloração entre a margem da 
restauração e a estrutura dentária, porém ela não penetra além da margem da restauração em direção à polpa; Charlie - código $\mathrm{C}$ - há descoloração marginal e ela penetra em direção à polpa.

Segundo $\mathrm{EICK}^{52}$, o primeiro pesquisador a legitimar a pesquisa clínica com materiais restauradores e a desenvolver critérios que avaliassem o comportamento dos mesmos foi Gunnar Ryge. Na opinião dele, quando se propõe estudar o performance clínica de resinas compostas ou qualquer outro material restaurador, o sistema Ryge deveria ser usado, por duas razões: (1) os critérios são baseados em julgamentos ou decisões compatíveis com as observações clínicas típicas dos Cirurgiões-Dentistas, (2) quando todos os critérios são usados, é o único sistema que fornece uma visão razoavelmente completa do comportamento clínico dos materiais restauradores.

As limitações da Odontologia Restauradora têm sido progressivamente reduzidas com os avanços nos materiais odontológicos, principalmente no campo da estética com as melhorias das técnicas adesivas, aperfeiçoadas constantemente. Entretanto, como acontece com todos os materiais dentários, quando formulações são mudadas para melhorar uma propriedade, há sempre o risco de que certas características desejáveis possam ser alteradas ou sacrificadas ${ }^{132}$.

As resinas compostas foram, ao longo do tempo, sofrendo alterações visando contornar algumas de suas limitações. Dois problemas clínicos são exaustivamente estudados nesta área, a infiltração marginal e o desgaste. O conhecimento mais profundo dos substratos dentários, principalmente o esmalte e a dentina, juntamente com o aprimoramento dos agentes adesivos, melhoraram bastante o comportamento das restaurações de resina no que diz respeito à infiltração marginal ${ }^{156}$. Já a maior resistência ao 
desgaste tem sido conseguida modificando-se a composição, tamanho e quantidade de carga das resinas ${ }^{156}$.

Quando se realiza uma pesquisa clínica, as condições dos experimentos são cuidadosamente controladas, porém isto não reflete o que ocorre quando os materiais testados são colocados à disposição dos Cirurgiões-Dentistas, que muitas vezes são incapazes de seguir as instruções dos fabricantes ou obedecer tais situações controladas por questões financeiras e/ou práticas.

O entusiasmo pelo potencial de um material às vezes é superestimado e pode levar ao risco da falha clínica, a qual pode condenar, não somente as qualidades do material, mas também o operador ${ }^{26}$.

Segundo LAMBRECHTS et al. ${ }^{98}$, todas as restaurações adesivas na região anterior deveriam ser capazes de proporcionar o seguinte:

- boa retenção da restauração e uma perfeita adaptação marginal;

- perfeita estabilidade da forma;

- resultado estético;

- uma reação de biocompatibilidade com os tecidos orais.

Entretanto, há alguns limites. Os limites das resinas compostas em dentes anteriores são determinados principalmente pelo:

- tamanho e natureza da lesão;

- as características dos materiais restauradores;

- a técnica de aplicação;

- a idade da restauração;

- o ambiente oral $^{98}$. 
As resinas compostas são materiais extremamente sensíveis. A complexidade do meio bucal é de tal monta que torna-se cabalmente impossível duplicar suas condições em tubos de ensaio (laboratório) ${ }^{133}$. Enfatizando a importância de comparar materiais num mesmo ambiente, TAY et al. ${ }^{182}$, em 1979, consideraram que certas condições bucais estabelecem melhor adequação a alguns materiais do que a outros, pois a agressividade do ambiente bucal reduz a longevidade das restaurações. A acidez da cavidade bucal e a higiene influenciam, também, na expectativa das resinas compostas para dentes anteriores ${ }^{98}$. Vários aspectos do comportamento dos materiais mostram-se diferentes quando expostos aos rigores das diferentes cavidades bucais. A ação da flora bucal sobre os materiais ou vice-versa estão associadas ao comportamento das restaurações.

A manipulação correta de qualquer material restaurador, em circunstâncias ideais, indubitavelmente, produz uma restauração que pode durar muitos anos. Entretanto, a vida de uma restauração é dependente de muitos fatores, e numa situação clínica típica nem sempre é possível ter perfeição, devido a tais influências como cooperação do paciente, tempo, acesso e habilidade do operador ${ }^{130}$.

A expectativa de vida útil de uma restauração de resina composta, tanto quanto de outros materiais, é difícil de se determinar. A média de idade das resinas compostas para dentes anteriores, segundo SMALES; WEBSTER; LEPPARD ${ }^{170}$ e MILLAR; ROBINSON; INGLIS ${ }^{113}$, baseados em acompanhamentos clínicos, foi de 7,9 anos. Segundo LAMBRECHTS et al. ${ }^{98}$ a média de vida útil de uma restauração anterior de resina composta é de 5 - 8 anos. Dados de trabalhos revisados por BROWNING; DENNISON ${ }^{25}$ mostraram que pacientes que receberam uma restauração de classe IV ou de classe V com resina composta têm, no máximo, 1 chance em 3 da mesma durar 3 anos e 1 chance em 2 de durar 5 anos ou 
menos. Talvez mais importante que estabelecer probabilidades de longevidade, seria ponderar: "Qual a expectativa média de vida de uma restauração de resina composta e quais fatores concorrem para uma maior ou menor longevidade?" e ainda "Por que restaurações de classe IV e V, com resina composta, apresentam menor vida útil que as de classe III?", pois os autores concluíram que das 1360 restaurações de classe III, IV e V estudadas, metade das de classe III falharam dentro de 10 anos e metade das de classe IV e V, dentro de 5 anos. Nessa mesma pesquisa, através dos dados obtidos nos questionários devolvidos pelos CirurgiõesDentistas consultados, ficou patenteado que as maiores causas de falhas das restaurações de classe III e V foram a cárie secundária e problemas com a integridade marginal, enquanto a perda do material restaurador foi a maior causa de falhas nas restaurações de classe IV.

Para o desenvolvimento deste trabalho, a preocupação com a qualidade da restauração foi constante. Desde o início observou-se, rigorosamente, os passos para a confecção dos preparos cavitários, a instalação do isolamento absoluto do campo operatório tornando o campo seco, limpo, propiciando condições ideais para a colocação do material restaurador. Os materiais restauradores foram manipulados de acordo com as instruções dos fabricantes buscando eliminar, assim, fatores que pudessem influenciar negativamente em suas propriedades.

ABDALLA; ALHADAINY² citam que os critérios usados para avaliação das restaurações de um trabalho de pesquisa realizado por eles em 1996, foram basicamente clínicos nos quais a deterioração poderia não ser detectada a menos que se tornasse evidente. Este fato deve ser levado em consideração, pois restaurações classificadas como "Alfa" podem até ter alguma discrepância, porém esta não progrediu o suficiente para ser percebida clinicamente. No referido estudo, 2 avaliadores independentes atuaram e sempre 
entravam em consenso quando havia desacordo na avaliação.

Semelhantemente, na presente pesquisa, 2 examinadores fizeram parte do acompanhamento seguindo o que Ryge; Snyder (1973) recomendaram, que é o exame das restaurações por 2 avaliadores, dando escores independentemente e que somente em casos de discordância eram reunidos para consenso ${ }^{43}$. A definição pelo emprego de 2 avaliadores também é concordante com NEO; CHEW $^{123}$, SMALES; CREAVEN ${ }^{167}$ e MILLAR; ROBINSON; INGLIS ${ }^{113}$, que em trabalhos de pesquisa clínica, valeram-se de dois examinadores para obtenção dos resultados e quaisquer diferenças eram igualmente harmonizadas pelo consenso. Ainda quanto ao número de avaliadores, DUPERON; NEVILLE; KASLOFF ${ }^{51}$ diferiram, neste sentido, utilizando em suas pesquisas, um único examinador, que desconhecia o tipo de material que havia sido usado para cada restauração. Desta forma, as restaurações eram avaliadas 2 vezes com um intervalo de tempo de 1 hora entre os exames.

Em seus estudos, RYGE; SNYDER (1973) conduziram um campo de teste para avaliar o efeito do treinamento prévio dos examinadores e chegaram a resultados num nível de $85 \%$ de concordância inter-examinadores ou intra-examinadores ${ }^{43}$. Identicamente neste trabalho seguindo-se a recomendação feita por esses autores e, também, por ELDERTON ${ }^{53}$ e por DAVIS; MAYHEW ${ }^{45}$, obteve-se uma concordância de 97,7\% o que eleva a confiabilidade dos resultados deste trabalho de acompanhamento clínico. Houve apenas um caso de discordância entre os dois examinadores no presente trabalho, sendo que após nova análise, concluíram que a restauração em questão estava no limite de uma classificação para outra ("borderline”), induzindo ao estabelecimento de um escore consensual. 
Todos os procedimentos operatórios, nesta pesquisa foram executados por um único operador para que se padronizasse todas as manobras e fornecesse maior credibilidade aos resultados alcançados. $\mathrm{CRABB}^{40}$ e GALAN JUNIOR et al. ${ }^{66}$ ressaltaram a importância dos procedimentos serem realizados por um único operador, numa pesquisa clínica, pois os dados são mais consistentes que os daquelas pesquisas, onde a técnica operatória é realizada por estudantes de diferentes graus de experiência ou por diversos profissionais.

Com base em outros trabalhos clínicos, como o de LEINFELDER et al. ${ }^{102}$, onde foram avaliadas resinas compostas para restaurações de dentes anteriores e posteriores, optou-se no presente trabalho por avaliar, comparativamente, uma resina composta, recentemente lançada no mercado odontológico, com outra de maior tempo de comercialização, por um período de 2 anos, face à adequação em termos de tempo para um estudo clínico que expusesse a sensibilidade dos materiais às agressividades do meio bucal, observação corroborada por BOZELL; CHARBENEAU ${ }^{20}$, ORAM; LYDERS ${ }^{126}$ que, de maneira idêntica, realizaram estudos de 2 anos de acompanhamento clínico. Além disso, VAN DIJKEN $^{189}$ salienta que a maioria das avaliações clínicas têm duração de 3 anos ou menos. ABDALLA; ALHADAINY² enfatizaram que o período de 2 anos, que foi o tempo que utilizaram avaliando resinas compostas, não é suficiente para indicar as propriedades dos materiais testados, mas pode indicar a tendência de suas performances futuras. Analogamente, o presente trabalho fornece subsídios para se elaborar um prognóstico a respeito das resinas compostas aqui estudadas. Uma continuidade neste acompanhamento clínico seria interessante e de grande valia. 


\subsection{SENSIBILIDADE PÓS-OPERATÓRIA}

No período de 2 anos, os pacientes não relataram qualquer sensibilidade pós-operatória nos dentes restaurados e acompanhados nesta pesquisa. Isto pode ser explicado, primeiramente, pela correta atenção dada à profundidade da cavidade e subsequentemente, ao uso adequado do material protetor do complexo dentinopulpar, sendo que não houve a necessidade de se fazer nenhuma proteção pulpar direta. Nas cavidades profundas, usou-se o cimento de hidróxido de cálcio e o cimento de ionômero de vidro ${ }^{116}$. Nas cavidades médias, somente o cimento ionomérico ${ }^{116}$. Os dados da pesquisa clínica realizada por MILLAR; ROBINSON; INGLIS ${ }^{113}$ e publicada em 1997, concordam com os deste trabalho, pois apesar de acompanharem as restaurações por 8 anos, não houve evidência de injúria pulpar; talvez isso também seja explicado pelo uso de uma base de hidróxido de cálcio em cada caso. O cimento de hidróxido de cálcio, além de ser um agente antibacteriano, estimula a formação de dentina esclerosada e reacional, protegendo a polpa contra os estímulos termelétricos ${ }^{116}$. O cimento de ionômero de vidro reduz a ação da contração volumétrica associada à polimerização da resina composta, provê uma fonte excelente de íons fluorídricos e tende a reduzir qualquer potencial para microinfiltração ${ }^{116}$. Segundo MONDELLI et al. ${ }^{116}$, sabe-se que: "nenhum sistema restaurador sela hermeticamente um preparo cavitário, quando muito se consegue um bom vedamento marginal”, sendo assim, uma adequada proteção do complexo dentinopulpar deve ser realizada. Desta forma, o cimento ionomérico vem obtendo grande aceitabilidade clínica, principalmente pelo fato de se unir quimicamente às estruturas dentárias e de apresentar coeficiente de expansão térmica linear bem próximo ao substrato dentário, contribuindo para a manutenção do vedamento marginal e para maior longevidade dessas restaurações em comparação com outros materiais $^{121}$. Além disso, esse material apresenta características biologicamente compatíveis 
com o complexo dentinopulpar evitando desconforto pós-operatório ${ }^{121}$.

Vale descrever os dados observados por RIBBONS; PEARSON ${ }^{141}$ e por MILLAR; ROBINSON; INGLIS ${ }^{113}$. De 79 restaurações anteriores (a maioria de classe III) e posteriores com resina composta, houve 1 caso de dor pós-operatória. Nenhuma causa óbvia foi encontrada, a dor diminuiu após 21 dias e o dente permaneceu vital. Numa outra avaliação feita também por RIBBONS; PEARSON ${ }^{141}$, de 94 restaurações, a maioria de classe III, $82 \%$ das restaurações foram protegidas, mas na opinião dos próprios autores, até que hajam evidências de que as resinas compostas não produzam reações adversas na polpa, comprovadas em pesquisas clínicas, todas as cavidades devem ser forradas.

As consequiências biológicas devem ser sempre consideradas quando se trata de contração de polimerização. Sabe-se que ao ser polimerizada, a resina composta sofre contração, provocando tensão na interface, e dependendo da magnitude das forças geradas nestas áreas poderá ocorrer rompimento das ligações adesivas e uma fenda maior ou menor pode permanecer nas paredes levando a sérios problemas clínicos. A fenda da contração poderá ser preenchida por fluido tecidual e bactérias, que ali se infiltram e proliferam graças às fontes de nutrientes disponíveis existentes na cavidade bucal. As sequelas poderão ser cárie secundária, inflamação pulpar e hipersensibilidade. Outra conseqüência da penetração de fluidos pela fenda marginal é a solubilização do material protetor da cavidade após 1 ou $2 \operatorname{anos}^{184}$. No caso do presente trabalho, a ausência de sensibilidade pós-operatória, provavelmente se deve aos cuidados complementares para se diminuir os efeitos da contração de polimerização que foram estabelecidos na confecção das restaurações, minimizando as consequências decorrentes de fendas marginais iniciais. Atenção especial foi estabelecida para a utilização adequada dos sistemas adesivos 
empregados, aos problemas de contaminação (sangue, saliva, oleosidade) com o emprego de isolamento absoluto, às variações do próprio substrato dentário (esmalte, tipo de dentina, profundidade), ao volume de resina composta empregado em cada incremento que era inserido na cavidade e submetido à ação da luz polimerizadora e, também, ao fator de configuração cavitária ${ }^{156}$. Sabe-se que pequenos volumes de resina induzem menor tensão na contração de polimerização, e que quanto menor for a relação entre o número de superfícies aderidas/material restaurador em contato com as paredes cavitárias e de superfícies livres voltadas para a fonte polimerizadora, maior será a facilidade de relaxamento das tensões oriundas da contração de polimerização ${ }^{30}$.

Como já foi destacado no parágrafo acima, tem sido demonstrado que com os sistemas restauradores resinosos, se a técnica adesiva não for adequadamente aplicada, poderá ocorrer microinfiltração na interface dente/restauração, o que poderá resultar em irritação pulpar contínua e sensibilidade ${ }^{132}$. Os passos para a técnica adesiva foram executados dentro do protocolo previamente estabelecido, proporcionando uma união efetiva, com bom vedamento marginal para os materiais restauradores, praticamente sem infiltração aparente e por conseguinte sem sensibilidade pós-operatória no período observado.

As resinas compostas do tipo híbrida apresentam atualmente alto módulo de elasticidade e baixo coeficiente de expansão térmica em relação às convencionais, principalmente devido à incorporação de maior volume de partículas inorgânicas e proporcionamento do tamanho das mesmas. A resina Fill Magic estudada é justamente um compósito híbrido, de partículas finas, com alto conteúdo de carga, encaixando-se perfeitamente nessas características.

As diferenças de coeficientes de expansão térmica linear entre os 
materiais restauradores e as estruturas dentárias podem também a médio e longo prazo serem responsáveis pela infiltração marginal. É lógico que, se durante as trocas térmicas houver diferenças de comportamento dimensional entre as estruturas dentárias e os materiais empregados para restauração, haverá tensão na interface e, subsequentemente rompimento das ligações adesivas estabelecidas anteriormente ${ }^{122}$.

Alguns autores como BRÄNNSTRÖM ${ }^{24}$ têm destacado a influência do coeficiente de expansão térmica nas restaurações de resina composta. Procurase, por meio da teoria hidrodinâmica, explicar a sensibilidade dolorosa dental, pela movimentação do fluido nos túbulos dentinários, em função da expansão térmica. Assim, quando uma fenda marginal propiciar, via túbulos dentinários, uma comunicação com a polpa, pode ocorrer o fenômeno estudado pela teoria citada. Devido às bebidas e alimentos frios ingeridos, ocorrerá a redução no volume do fluido no interior da fenda e isto ocasiona um rápido fluxo do fluido dentro dos túbulos, de fora para dentro, em direção à polpa ajudado pela ação da capilaridade. Segundo TORSTENSON; BRÄNNSTRÖM ${ }^{184}$ a hipersensibilidade a mudanças de temperatura não significa necessariamente que as variações de temperatura de pequena duração possam resultar em fendas marginais largas. Sendo assim, para minimizar os problemas de hipersensibilidade e de formação de fenda marginal, o emprego de um material que apresente um coeficiente de expansão térmica próximo ao das estruturas dentárias é benéfico $^{156}$. Os ionômeros de vidro têm essa propriedade, além do baixo módulo de elasticidade e devem ser empregados, sempre que possível, como material intermediário. Desta forma, o cimento ionomérico foi usado como material intermediário na maioria dos casos desta pesquisa e associando-se o fato das resinas compostas híbridas apresentarem um baixo coeficiente de expansão térmica, em relação às demais, pode ter contribuído para os excelentes resultados encontrados com relação à sensibilidade pós-operatória. 
A força de contração, quando não se usa material de proteção intermediário, pode promover o deslocamento do fluido dentinário dentro dos túbulos. Pela teoria hidrodinâmica descrita por BRÄNNSTRÖM ${ }^{24}$, o deslocamento do fluido dentinário nos túbulos, estimula os mecanorreceptores na polpa causando a sensibilidade pós-operatória. Nas cavidades rasas foi realizada apenas a hibridização, porque a faixa de dentina que permaneceu entre a restauração e a polpa era grande. Com isso, a própria dentina juntamente com o vedamento feito pela hibridização forneceu condições para a ausência de sensibilidade pósoperatória.

As deformações sofridas pelos dentes pelo efeito do módulo de elasticidade podem acarretar rupturas das ligações adesivas. $\mathrm{O}$ uso de um material com baixo módulo de elasticidade, ou seja, com maior resiliência, pode favorecer a restauração na presença de esforços. Como foi salientado, a resina composta híbrida possui um alto módulo de elasticidade, entretanto, seu volume total foi diminuído pela colocação do cimento de ionômero de vidro, que tem baixo módulo de elasticidade e é capaz de acompanhar as deformações elásticas, traduzindo-se numa associação muito vantajosa. Também OYSAED; RUYTER $^{128}$ mostraram que a absorção de água, pela resina composta, diminui o módulo de elasticidade, fazendo com que elas acompanhem melhor as deformações sofridas durante sua vida clínica. Deve-se lembrar que os resultados satisfatórios do presente estudo clínico com relação à sensibilidade pós-operatória, também neste aspecto, foi favorecido por esses acontecimentos e essa manobra operatória, além do que, numa restauração de classe III, o esforço mastigatório não é um aspecto preocupante.

Não se pode esquecer que as resinas compostas também passam pelo processo de expansão higroscópica, que compensa, em parte, a contração de 
polimerização, amenizando os efeitos maléficos da presença da fenda marginal ${ }^{7,17,70,71,74,76}$.

Todos os passos operatórios citados foram, assim, utilizados neste trabalho com o intuito de se conseguir o máximo das resinas compostas empregadas e minimizar o aparecimento de falhas. É bem provável que o fator sensibilidade pós-operatória tenha recebido apenas escores 0 (zero), durante todo o período de avaliação, devido a esses cuidados tomados, que proporcionaram adequada proteção e saúde para a polpa.

\subsection{FORMA ANATÔMICA}

O processo de desgaste in vivo, com perda da forma anatômica, é parcialmente devido à degradação hidrolítica das partículas de carga ${ }^{173,174}$. Se por um lado a absorção de água é necessária para compensar a contração de polimerização, por outro influencia as propriedades mecânicas das resinas compostas. O silano pode proteger a superfície da partícula de carga da degradação hidrolítica ou formar uma união entre a partícula e a matriz ${ }^{188}$. Essa cobertura é influenciada pela geometria da superfície da partícula de carga, sua composição e a presença de materiais estranhos. Deste ponto de vista, o processo de obtenção das partículas de carga pode ser crítico já que ambos geometria e contaminantes serão determinados pelo próprio processo de manufatura. Além disso, grandes moléculas de agente de união podem não cobrir toda a superfície disponível nos sítios ativos. Portanto, moléculas de água menores podem alcançar e atacar a superfície do vidro nos lugares incompletamente cobertos pelas moléculas do agente de ligação silano ${ }^{188}$. SÖDERHOLM ${ }^{172}$ (1981) e SÖDERHOLM et al. ${ }^{175}$ (1984) publicaram resultados fortemente indicativos dessa possibilidade da água atacar a união do $\mathrm{SiO}$ (óxido de silício) à partícula de carga da superfície, resultando numa desunião da matriz/carga em virtude da degradação hidrolítica das uniões siloxanas. 
Com a perda das partículas pelo seu deslocamento da superfície da matriz orgânica, esta vai sendo desgastada e a restauração vai perdendo sua forma anatômica original com o passar do tempo. As restaurações com as resinas compostas aqui estudadas não sofreram alterações na forma anatômica, recebendo somente escores 0 (zero), em todos os períodos examinados. Isto sugere que a degradação hidrolítica não foi tão expressiva a ponto de desgastar a superfície da restauração, alterando sua forma anatômica.

A escova dental e abrasivos de cremes dentais podem afetar a superfície das resinas compostas, com perda de substância. $\mathrm{AKER}^{4}$, num estudo para verificar a resistência a abrasão das resinas compostas às escovas dentais, em 1982, verificou que ocorriam perdas médias de aproximadamente $0,035 \mathrm{~mm}$ após 240.000 movimentos (estimado ser de 15 anos de escovação simulada), em superfícies de resinas compostas convencionais e de micropartículas. Transportando esses dados para o presente trabalho, fazendo uma proporcionalidade, poder-se-ia dizer que houve uma perda de substância de superfície de 0,0047 mm, em 2 anos de vida clínica, com os pacientes realizando escovações normalmente. Isto parece não ter tido muita significância clínica, pelo menos visual e à sondagem, já que não houve alterações na forma anatômica como registraram os dados colhidos pelos avaliadores deste trabalho.

\section{Segundo SHORTALL; WILSON; HARRINGTON ${ }^{155}$ um} insuficiente grau de conversão do monômero em polímero pode resultar em inadequada resistência ao desgaste. Numa massa de resina composta polimerizada de forma não adequada, obviamente, todas as boas características ficam prejudicadas. Como já foi mencionado, a forma anatômica das restaurações deste trabalho não alterou, fato este que, com base na citação desses autores, pode-se supor que houve um bom índice de conversão da 
resina inserida na cavidade, até porque a técnica incremental foi estabelecida e a intensidade da luz do aparelho usado nesta pesquisa estava dentro dos padrões exigidos para que tal resultado fosse alcançado. A polimerização inicial foi realizada através das paredes vestibular ou lingual dos preparos cavitários, usando-as como uma interposição para que a intensidade da luz fosse menor nos primeiros segundos do tempo estabelecido para a polimerização da superfície em questão. Este procedimento possibilita diminuir as tensões geradas na interface dente/restauração durante o processo, o que poderia levar a um desequilíbrio entre estas tensões e as propriedades visco-elásticas do sistema restaurador ${ }^{156}$. Os trabalhos de FEILZER et al. $^{58}$, UNTERBRINK; MUESSNER ${ }^{187}$ e UNO; ASMUSSEN ${ }^{186}$ mostram bem estes aspectos, ou seja, quando intensidades de luz mais baixas foram empregadas, a integridade de margens ou adaptação marginal de restaurações de resina composta foram melhores.

Os dados observados neste trabalho superam os conseguidos por RIBBONS; PEARSON ${ }^{141}$ que obtiveram 5 casos de mudança no contorno das 200 restaurações de Adaptic investigadas por 2 anos. Apesar de ser um baixo índice (2,5\%) esse fato deve-se ao tipo de resina composta utilizada, ou seja, uma resina convencional, sendo que na presente pesquisa, o índice de alteração da forma anatômica foi nulo quando empregou-se as resinas do tipo híbridas.

As observações deste trabalho são semelhantes aos dados obtidos por NEO et al. ${ }^{124}$ que, relataram, após estudos clínicos, que todas as restaurações permaneceram com a forma anatômica estável durante o período de avaliação (18 meses) e que não houve diferenças entre as 2 resinas compostas estudadas. Analogamente, avaliando 104 restaurações de classe I, utilizando 4 resinas compostas, entre elas a Z-100, num período de 2 anos, ABDALLA; ALHADAINY², na análise final do tempo da pesquisa, concluíram 
que não houve alteração na forma anatômica. Todas as restaurações tiveram 100\% de escores Alfa nessa avaliação, cuja porcentagem coincide com a encontrada no presente trabalho.

A insuficiência de trabalhos de pesquisa clínica com a resina composta Z-100 não permite grandes estudos comparativos, apesar de ser um material restaurador largamente utilizado por Cirurgiões-Dentistas do mundo todo. Ao se fazer o levantamento bibliográfico, depara-se, atualmente com um número muito grande de pesquisas clínicas sobre cimentos de ionômero de vidro modificados por resina, que têm invadido o mercado odontológico.

\subsection{CÁRIE SECUNDÁRIA}

As resinas compostas, segundo GLANTZ ${ }^{68}$, LARATO $^{99}$ e SKJORLAND ${ }^{158}$ parecem ter uma tendência em promover a formação e acumulação de placa dental. As resinas compostas e mais particularmente a interface dente/restauração está propensa à formação de colônias de microorganismos. SVANBERG; MJÖR; ORSTAVIK ${ }^{181}$ estudando cimento de ionômero de vidro, amálgama e resina composta, demonstraram várias quantidades de colônias de microorganismos, mensuradas por meio de unidades formadoras de colônias (UFC). Eles reportaram que nas restaurações de ionômero de vidro, o total das unidades formadoras de colônias de estreptococos mutans era o mais baixo e nas de resina composta era o mais alto. A quantidade de placa madura e a prevalência de estreptococos mutans foi maior nas restaurações de resina composta que nas de amálgama e ainda menor nas restaurações de cimento de ionômero de vidro. Em números, encontraram nas margens proximais das restaurações de cimento de ionômero de vidro 1,1 UFC, amálgama 4,3 UFC e resina composta 13,7 UFC. Isto sugere que por períodos prolongados, o potencial da placa de induzir cárie secundária pode ser mais baixo nas restaurações de ionômero de vidro, seguidas 
das de amálgama e das de resina composta. A idêntico resultado chegaram SÁ et al. ${ }^{151}$, onde avaliando o potencial antimicrobiano de materiais forradores e restauradores concluíram que houve halos de inibição do crescimento microbiano somente ao redor do cimento de ionômero de vidro (Vitrebond) e do cimento de hidróxido de cálcio (Hydro C) e a resina composta e demais materiais permaneceram inertes. Considerando estes resultados, percebe-se que a interface de uma restauração de resina composta favorece a colonização microbiana, e logicamente, no paciente com higiene bucal não adequada este aspecto torna-se ainda mais negativo $^{156}$. Isto reforça a necessidade de uma avaliação inicial do paciente quanto ao risco de cárie e adequação do mesmo antes de receber qualquer material restaurador e em especial a resina composta. Os avaliadores deste estudo não registraram a existência de nenhum caso de cárie secundária, o que pode ser explicado pelo fato dos pacientes terem mantido uma higiene bucal adequada, instruída no início da pesquisa e reforçada nas avaliações subsequentes, impedindo o acúmulo de placa, principalmente na interface dente/restauração e pela análise inicial e adequação das condições bucais dos pacientes envolvidos nesta investigação.

Comparada com outras 6 resinas (P-50 - 3M, Herculite XR - Kerr, Conquest - Jeneric/Pentron, Prisma APH - Dentsply, Silux Plus - 3M, Heliomolar Vivadent), por VERSLUIS; DOUGLAS; SAKAGUCHI ${ }^{193}$, a Z-100, que é uma resina composta híbrida, foi a que apresentou menor coeficiente de expansão térmica $\left(22,5 \times 10^{-}\right.$ ${ }^{6} /{ }^{0} \mathrm{C}$ ), portanto mais próximo do da coroa dental, confirmando outros estudos, os quais demonstraram os benefícios do aumento do conteúdo de carga igualando às propriedades dos tecidos duros dentais. O coeficiente de expansão térmica das resinas compostas, de uma forma geral, varia de 20 a $80 \times 10^{-6} /{ }^{0} \mathrm{C}{ }^{78}$. Para o dente, é de aproximadamente $17 \times 10^{-6} /{ }^{0} \mathrm{C}$ para o esmalte e $11 \times 10^{-6} /^{0} \mathrm{C}$ para a dentina ${ }^{79}$. A resina composta Fill Magic, da mesma forma, contém grande quantidade de carga, com isso, supõe-se que seu coeficiente de expansão 
térmica linear seja semelhante ao da Z-100. Isso foi benéfico para as restaurações, pois as flutuações térmicas do ambiente bucal, que são originadas da $\operatorname{dieta}^{193}$ não determinaram maiores alterações volumétricas, diminuindo o índice de infiltração marginal, conseqüentemente possibilitando que a totalidade das restaurações deste estudo não manifestasse nenhum caso de cárie secundária.

Vale ressaltar que, em todos os preparos cavitários, o esmalte estava presente nas paredes circundantes, o que propiciava um vedamento se não ideal pelo menos bem efetivo. A presença de esmalte circundando toda a cavidade é, sem dúvida, um fator favorável ao melhor comportamento clínico das restaurações de resina composta, principalmente no que diz respeito ao vedamento marginal, pois o esmalte é um substrato homogêneo ${ }^{156}$.

Considerando o risco de cárie secundária e para minimizar problemas de fendas marginais, uma certa quantidade de absorção de água parece ser uma necessidade já que todas as resinas compostas contraem durante a polimerização e nenhum agente de união dentinária disponível comercialmente é capaz de eliminar totalmente a microinfiltração $^{72,73,74,75,88,96,118 \text {. As observações de HANSEN }}{ }^{72,73}$, MUNKSGAARD; HANSEN; ASMUSSEN ${ }^{118}$, JÖRGENSEN; ITOH; MUNKSGAARD ${ }^{88}$, HANSEN; ASMUSSEN $^{74,75}$ e KOMATSU; FINGER ${ }^{96}$ vêm ratificar o que já foi discutido com relação ao critério sensibilidade pós-operatória. A absorção de água compensa, em grande parte, a contração de polimerização, que como salientado anteriormente, não deve ter sido muito evidente nesta pesquisa, face aos cuidados adotados como: técnica incremental de inserção da resina com pequenos volumes, amenizando as tensões criadas na interface e diminuindo, conseqüentemente, a fenda marginal. O emprego de materiais com baixo módulo de 
elasticidade sob as restaurações, como o cimento de ionômero de vidro, auxilia na assimilação das tensões geradas durante a contração de polimerização, diminuindo a infiltração marginal $^{156}$. Sendo o cimento ionomérico um material mais flexível, quando interposto, acompanha melhor as movimentações oriundas das deformações provenientes da mastigação $^{156}$. Desta forma, todos estes aspectos estabeleceram, em conjunto, a ausência de cárie secundária, uma vez que tanto o material restaurador como a técnica empregada concorrem igualmente para a vida útil da restauração.

Assim, a técnica adesiva, por melhor que seja o sistema, não poderá evitar que desafios cariogênicos freqüentes, que envolvam a interface dente/restauração principalmente na região cervical, constitua-se em condição favorável para o desenvolvimento de cárie secundária. Como já foi explicitado, todos os cuidados foram tomados neste aspecto, vindo somente confirmar os resultados clínicos encontrados pelos examinadores.

Trabalho de RIBBONS; PEARSON ${ }^{141}$ relata em avaliação clínica de restaurações com resina composta Adaptic, onde a maioria era de classe III, as quais permaneceram com aparência satisfatória num período acima de 2 anos. Nenhuma restauração foi fraturada ou se deslocou e nenhum caso de cárie recorrente foi registrado. Estes dados com relação à cárie secundária são concordantes com os desta pesquisa clínica, com uma ressalva: aqueles autores usaram uma resina convencional.

É possível, também, que a ausência de cárie secundária deva-se ao fato da cidade de Bauru, onde foi desenvolvido o acompanhamento clínico, possuir água de abastecimento público fluoretada, o que pode ter contribuído positivamente nas superfícies dentárias adjacentes às restaurações, pois segundo KING; YUNG; HOLMGREN ${ }^{94}$ a água fluoretada protege contra as cáries mais de $85 \%$ em superfícies lisas e $75 \%$ em superfícies 
interproximais. O uso de cremes dentais fluoretados pelos pacientes desta pesquisa clínica, também entra com sua parcela de colaboração concorrendo para um resultado positivo com relação à inibição de cárie secundária.

Talvez fosse interessante agrupar e discutir conjuntamente os critérios cárie secundária, sensibilidade pós-operatória, integridade marginal e descoloração marginal, porque muitos aspectos que já foram salientados, como por exemplo, os efeitos da contração de polimerização, do coeficiente de expansão térmica, de uma técnica adesiva bem ou mal executada, da expansão higroscópica, enfim, todos têm uma ação direta sobre os critérios citados.

\subsection{INTEGRIDADE MARGINAL/DESCOLORAÇÃO MARGINAL}

Vários fatores são associados com a adaptação marginal de qualquer material restaurador. Os fatores que tendem a melhorar a adaptação são a união mecânica da resina composta ao esmalte condicionado e a absorção de água do material ${ }^{26}$. Os fatores que tendem a reduzir a adaptação marginal são a contração de polimerização e alterações dimensionais associadas ao coeficiente de expansão térmica ${ }^{26}$. Outros fatores tais como remoção de esmalte muito fragilizado ou já fraturado nas margens cavitárias pode também auxiliar na adaptação marginal e são aplicáveis a todos os materiais ${ }^{26}$.

Nos preparos cavitários da presente pesquisa, teve-se a cautela de verificar se as margens de esmalte estavam muito frágeis ou quebradiças. Em caso positivo, era feita a planificação do mesmo com instrumentos apropriados, como medida de segurança para uma perfeita adaptação da restauração ao dente, justamente para que a integridade marginal não sofresse alteração. Na região cervical, onde normalmente a espessura de esmalte é menor, envidava-se os maiores cuidados para evitar a remoção do mesmo, pois como já foi 
salientado todas as cavidades deste estudo apresentavam esmalte nas paredes circundantes.

A performance da resina composta Z-100 com relação à integridade marginal e descoloração marginal foi comparada com outras 3 resinas - Herculite XR, Clearfil Photo Posterior e Heliomolar RO - por ABDALLA; ALHADAINY². Um total de 104 restaurações de classe I foram executadas, tendo, os autores, ao final de 2 anos, obtido $100 \%$ de escores Alfa para a Z-100 em ambos os quesitos. Coincidentemente, idênticos resultados foram conseguidos no presente trabalho.

A contração de polimerização das resinas compostas, como é sabido, acontece sempre, sendo que alguns dos seus efeitos maléficos já foram citados neste capítulo. Tratar-se-á doravante desses efeitos, relacionandos-os, de modo especial, com a integridade e descoloração marginal.

De acordo com FEILZER; DE GEE; DAVIDSON ${ }^{57}$ a contração de polimerização gera estresses dentro da resina composta. Ao unir-se às paredes cavitárias, parte desse estresse é diminuído pelo escoamento plástico do material e parte dele permanece como tensão elástica dentro do mesmo. A magnitude do estresse nas uniões marginais dependerá da quantidade de contração de polimerização e do alívio devido à absorção de água acompanhado pela expansão da resina composta.

Apesar das melhorias, as resinas compostas ativadas por luz visível continuam a contrair em valores que variam de 3 a $6 \%$ após a primeira hora da sua colocação $^{180}$. Isto pode ter implicações na integridade das margens das restaurações e na alteração de cor que podem estar associadas à presença de fendas e à infiltração de microorganismos na interface dente/restauração ${ }^{31}$ e se o condicionamento ácido e a união forem inadequados, aí então tudo se intensifica. Um bisel com conformação adequada, ou 
seja, com terminação que não propicie borda em ponta de faca, preparado no ângulo cavosuperficial, é muito importante por permitir uma maior espessura de resina, mascarar a linha de união dente/restauração, expor transversalmente os prismas de esmalte, aumentar a área e energia de superfície, atuando em conjunto com o sistema adesivo para minimizar a infiltração e a descoloração marginal.

De acordo com SMALES ${ }^{163}$, margens de excelente qualidade são obtidas seguindo as orientações técnicas dos diferentes sistemas adesivos, bem como inserção do material restaurador. Em cavidades onde o esmalte recebeu condicionamento ácido seguido dos cuidados inerentes à aplicação do agente de união, obtiveram os melhores resultados com relação à descoloração marginal.

Existe ainda um aspecto que pode determinar o manchamento das margens da restauração com o passar do tempo e que se relaciona com o ato de inserção da resina na cavidade, colocando-a além do esmalte biselado e que não se remove no acabamento, provocando uma falta de união entre a resina composta e o dente, propiciando, além da degradação de borda, a deposição de material orgânico e pigmentos provenientes da alimentação e de outros hábitos, que favorecem a alteração de cor da margem da restauração ${ }^{31}$.

Supõe-se que a obtenção somente de escores 0 (zero) para a integridade marginal e descoloração marginal nesses 2 anos estudados foi devido à observação estabelecida com padronização do bisel, condicionamento ácido, aplicação do sistema adesivo, inserção dos materiais restauradores, aos cuidados dados ao acabamento da restauração, removendo resina que, por ventura, situava-se além do bisel e esmalte condicionado, o que poderia permitir falhas precoces na interface dente/restauração, por 
promoção de pequenas fraturas marginais e conseqüentemente descoloração na interface.

A adaptação marginal das resinas compostas pode ser melhorada pela expansão higroscópica das restaurações ${ }^{7,17,70,71,74}$. A absorção de água pelos polímeros, e sua conseqüiente expansão higroscópica depende de algumas variáveis, uma das quais é a proporção volumétrica entre a carga e a matriz. Quanto maior a proporção carga/matriz orgânica, menor a absorção de água, conseqüentemente uma matriz orgânica reduzida, resultará em absorção de água reduzida ${ }^{21}$. É importante ressaltar que muito poucas resinas compostas possuem expansão higroscópica que compensa completamente a contração de polimerização ${ }^{7,70,71}$.Após a absorção de água, uma avaliação das margens pode resultar numa alta porcentagem de margens excelentes ${ }^{187}$.

A absorção de água continua por um certo tempo ${ }^{17,21}$, mas a maior parte se dá nos primeiros $7 \operatorname{dias}^{21,70,71}$. Persistindo uma fenda residual, não diminuída pela expansão higroscópica, após 28 dias, a absorção de água além deste período é provavelmente de pouca ou nenhuma relevância clínica. BARREIROS; ARAÚJO; NAGEM FILHO9 mostraram que a hidratação da resina composta se completa após 3 semanas (21 dias) da sua inserção no preparo cavitário. Esses autores argumentam que o acabamento e polimento das restaurações de resina composta deve ser adiado por 21 dias ou mais, a fim de que elas se hidratem totalmente e reduzam a fenda marginal provocada pela contração de polimerização. Eles experimentaram, também, o acabamento e polimento em 10 minutos e 7 dias e concluíram que as fendas eram progressivamente menores, conforme aumentava-se o período de espera. Também BATITUCCI ${ }^{10}$, trabalhando semelhantemente a esses autores, executando o polimento aos 10 minutos, 1 dia e 7 dias após a polimerização do material no preparo cavitário, relatou que este deve ser adiado por 7 dias ou mais, a fim de que ocorra o 
fechamento das fendas marginais, como consequiência da expansão higroscópica do material restaurador no meio bucal. Na presente pesquisa, o acabamento e polimento foi realizado 1 semana após a confecção da restauração, pois a intenção era aproximar o máximo possível de uma situação que ocorre corriqueiramente nos consultórios odontológicos, uma vez que os Cirurgiões-Dentistas, na grande maioria dos casos, os executam nesse período. Pelo que pôde ser notado, na presente avaliação este fato parece não ter influenciado negativamente em nenhum dos aspectos estudados.

O polimento das restaurações de resina composta é necessário para eliminar, adicionalmente, a camada inibida pelo oxigênio, não completamente polimerizada, na superfície da resina, o que poderia, prematuramente deteriorá-la ${ }^{13}$.

As resinas compostas usadas neste estudo possuem alto conteúdo de carga inorgânica. Com base nas citações de BRADEN et al. ${ }^{21}$ a respeito da proporção carga/matriz, quanto menos matriz orgânica, menos absorção de água. Devido a este fato, provavelmente, as resinas não tenham alcançado um grau satisfatório de expansão higroscópica, porém o suficiente para, em associação com a técnica incremental de inserção do material restaurador, terem providenciado uma boa adaptação da resina nas margens ou uma fenda tão pequena que não foi detectada por meio da sonda exploradora e que também não foi capaz de infiltrar pigmentos a ponto de ficarem armazenados na interface, descolorindo marginalmente. Por isso, houve registros apenas de escores 0 (zero) nestes critérios.

SALEH et al. ${ }^{152}$ realizaram uma pesquisa examinando restaurações com explorador encontrando 2 tipos de falhas marginais. Em uma, as margens quebraram quando o explorador foi movimentado do dente para a superfície da restauração. De acordo 
com os autores, isto pode significar que parte do material fraturou-se nas margens (biséis). A outra falha foi a perda do material quando o explorador foi movimentado da superfície da restauração para o dente, como se estivesse faltando material na restauração. Os autores justificaram essa ocorrência informando que isto parece ser resultado de uma desintegração ou degradação do material, a qual pode ter sido causada por problemas imperceptíveis na manipulação do material e do ambiente, tal como leve contaminação durante a restauração ou inclusão de bolhas de ar. Isto sugere que o excelente comportamento da integridade marginal, no presente estudo, pode significar que não houve, no período estabelecido, desintegração dos materiais, o que pode ser justificado pela correta manipulação dos mesmos, seguindo as normas do fabricante, sem contaminação durante a restauração, já que todo o procedimento foi desenvolvido com isolamento absoluto do campo operatório e em ambiente com temperatura controlada.

Analisando as fotografias obtidas pela microscopia eletrônica de varredura, no presente trabalho, evidencia-se não ter ocorrido alteração na integridade marginal das restaurações, fato este que merece destaque. Percebe-se nitidamente que não há descontinuidade e as áreas marginais mostraram uma transição lisa da restauração para o esmalte.

NEO et al. ${ }^{124}$ desenvolveram um trabalho avaliando clinicamente 4 materiais estéticos (2 resinas compostas - APH e Lite Fil II e 2 ionômeros de vidro - Fuji Cap II e Fuji II LC) usados para tratar lesões cervicais por abrasão em 83 dentes, num período de 18 meses. Usando o método de Ryge modificado para avaliá-las, os autores concluíram que um número significante de restaurações para os materiais estudados, incluindo as 2 resinas compostas, uma das quais híbrida $(\mathrm{APH})$, sofreu alguma perda na integridade marginal. $\mathrm{Na}$ 
avaliação das resinas compostas, das 21 restaurações com APH, somente 7 (33\%) permaneceram com escore Alfa e das 13 com Lite Fil II, somente 3 (15\%). As outras restaurações deterioraram-se clinicamente. Confrontando os resultados obtidos pelos pesquisadores nomeados com a presente pesquisa, percebe-se a dissonância das conclusões relativas à integridade marginal e descoloração marginal. Deve-se levar em consideração que os autores avaliaram restaurações confeccionadas em lesões cervicais. A perda da integridade marginal ocorreu em $67 \%$ dos casos e a descoloração marginal foi estatisticamente significante para a resina composta híbrida (APH), onde praticamente $50 \%$ delas receberam escores Bravo ao final de 18 meses $^{124}$. Segundo os próprios autores, os fatores que contribuíram para a perda da integridade e descoloração marginal para todos os materiais utilizados na pesquisa são a perda contínua da estrutura dental ou a ocorrência de pequenas fraturas do material nas margens, especialmente a configuração da lesão de abrasão permitiu somente a colocação de uma fina camada do mesmo. Por outro lado, é de se supor que as restaurações cervicais podem sofrer tensões geradas pelas forças oclusais que atuam, possivelmente, como colaboradoras no processo de deterioração das margens.

ROULET; SEEWALDT; NOACK ${ }^{143}$ realizaram um trabalho para determinar, in vitro, a qualidade das margens das restaurações de classe III e IV com resinas compostas híbrida e microparticulada. Por meio de testes de termociclagem e de estudos de fotomicrografias, eles concluíram que as melhores qualidades de margens foram encontradas nas restaurações de classe III, não sendo encontrada correlação entre as propriedades mecânicas e a performance clínica das resinas compostas. As características de manipulação têm muito mais influência na performance clínica. Embora seja um trabalho in vitro, os autores notaram que as margens com maior integridade eram observadas nas restaurações de classe III. Fazendo uma analogia com este estudo clínico, também este fato pode ser 
comprovado.

Num universo de 1360 restaurações pesquisadas por BROWNING; DENNISON $^{25}$, 37 foram excluídas por falhas no registro das informações. Das 1323 restaurações consideradas, 583 eram de classe III, 322 de classe IV e 418 de classe V. As porcentagens de falhas que provocaram as substituições das restaurações foram, pela ordem, de 12,8 , 35,5 e 33,3, num período de 3 anos, que corresponde respectivamente a 74, 114 e 139 restaurações. Os autores concluíram que de um total de 74 de classe III, que falharam, a seguinte correspondência podia ser feita entre porcentagem de falhas e número de restaurações: cárie secundária $-37,5 \%=28$ restaurações; integridade marginal $-15,6 \%=12$ restaurações; descoloração marginal $-6,3 \%=5$ restaurações; cor $-3 \%=2$ restaurações; forma anatômica $-0 \%=$ nenhuma restauração. Os dados referentes à forma anatômica e cor, relatados acima, coincidem com os encontrados na presente pesquisa, sendo que para os demais ítens não houve concordância. Os autores do citado trabalho não mencionam as prováveis causas das porcentagens de falhas das restaurações.

Se os coeficientes de expansão térmica do dente e do material restaurador não forem iguais, as mudanças repetidas de temperatura induzem estresses nas margens aderidas, os quais somam-se aos estresses criados durante a contração de polimerização $^{44,57}$. Tanto o $\mathrm{pH}$ como a temperatura da boca, estão sujeitos a flutuações. A complexidade do ambiente bucal, associado ao fato do coeficiente de expansão térmica das resinas compostas ser maior que da estrutura dental faz com que elas se comportem de diferentes maneiras ${ }^{133}$. A estabilidade dimensional da resina composta é muito importante para que a integridade marginal e a descoloração se mantenham inalteradas no transcorrer de sua vida clínica. O cimento de ionômero de vidro que foi usado como protetor pulpar, na 
maioria dos casos desta pesquisa, atuou também diminuindo a quantidade de resina composta necessária para restaurar o dente. Além de o coeficiente de expansão térmica linear do ionômero de vidro ser mais próximo da estrutura dentária e liberar flúor nas possíveis fendas marginais, possibilitou usar menor quantidade de resina, a qual apresenta alto coeficiente de expansão térmica, com maior instabilidade dimensional. Com isso foi possível diminuir os efeitos de contração/expansão frente às mudanças de temperatura, possivelmente contribuindo para a estabilidade da integridade marginal e da inexistência de descoloração marginal, principalmente na região cervical, onde o esmalte apresenta pequena espessura.

Numa avaliação clínica de 4 resinas compostas, conduzida por CRUMPLER et al. ${ }^{42}$, por 5 anos, materiais que possuem menor conteúdo de carga e coeficientes de expansão térmica maior exibiram maiores incidências de descoloração marginal. A afirmação desses pesquisadores pode justificar, no presente trabalho, a ausência de alteração na descoloração marginal, pelo emprego das resinas compostas híbridas, que apresentam alto conteúdo de carga e baixo coeficiente de expansão térmica, sem alterações dimensionais significativas e que, conseqüentemente, minimizam a formação de fendas marginais e de pigmentação interfacial.

Desde a introdução das resinas compostas ativadas por luz visível no final dos anos 70, houve um rápido aumento no número e variação de produtos disponíveis e muitas mudanças nas formulações ${ }^{155}$.

O sistema de luz visível que polimeriza as resinas compostas funciona com 2 filtros que bloqueiam os raios das extremidades, correspondentes aos espectros ultravioleta e infra-vermelho, e um outro filtro que assegura a passagem de apenas um feixe de luz visível ${ }^{194}$. 


\subsection{COR}

Algumas considerações que serão feitas a seguir merecem ser destacadas, para um melhor entendimento de como se dá a percepção visual da cor, que está intimamente relacionada com a incidência da luz.

Um objetivo importante na odontologia moderna é restaurar a cor e a aparência da dentição natural. Por isto, considerações estéticas em odontologia restauradora assumiram uma grande prioridade. Assim, por exemplo, busca-se um material restaurador que possa ser usado em todas as condições e aplicado diretamente ao dente, restaurando sua cor. Isto constitui um desafio atual na pesquisa dos materiais dentários ${ }^{133}$.

A luz é uma forma de radiação eletromagnética que pode ser detectada pelo olho humano. Este é sensível a comprimentos de onda que vão de aproximadamente 400 nanômetros (violeta) até 700 nanômetros (vermelho-escuro). A combinação de intensidades de comprimentos de onda presentes no feixe de uma luz determina a propriedade usualmente chamada de $\operatorname{cor}^{133}$.

Para que um objeto seja visível, ele deve emitir luz, ou então, refletir ou transmitir a luz incidente proveniente de uma fonte externa. Este último tipo é o caso dos objetos que têm interesse odontológico. A luz incidente é de maneira usual policromática, ou seja, uma mistura de vários comprimentos de onda. A reação de um objeto à luz incidente é absorver e/ou difundir certos comprimentos de onda de uma maneira seletiva $^{133}$. O espectro de reflectância dos materiais para restaurações estéticas e dos tecidos duros dentais diferem, e as diferenças dependem do comprimento de onda da luz incidente ${ }^{39}$. Os valores de "tristimulus" representam a quantidade dos 3 estímulos primários (vermelho, verde e azul) requeridos para dar a cor ${ }^{60}$. 
O fenômeno da visão e a terminologia correspondente podem ser ilustrados ao se considerar a resposta do olho humano em relação à luz que vem de um objeto. Esta luz que incide no olho direciona-se para a retina e é convertida em impulsos nervosos, os quais são transmitidos para o cérebro. As células cônicas da retina são responsáveis pela visão da cor. Estas células têm um limiar de intensidade necessário para a visão da cor e exibem uma curva resposta relacionada com o comprimento de onda da luz incidente. O olho é mais sensível à luz na região correspondente ao verde e amarelo e é menos sensível nos extremos, ou seja, na região do vermelho e do azul ${ }^{133}$.

Como a resposta nervosa está envolvida na visão da cor, a estimulação constante através de uma cor única pode resultar na fadiga em relação à mesma, diminuindo, como conseqüência, a resposta do olho. Os sinais da retina são processados pelo cérebro para que seja produzida a percepção psicofisiológica da cor. Do ponto de vista científico, o olho humano normal pode ser comparado a um colorímetro diferencial de alta sensibilidade. O olho se compara ou excede aos melhores instrumentos atualmente utilizados, que têm a capacidade de diferenciar duas cores, quando colocadas lado a lado ${ }^{133}$. Esse órgão tão sensível que permite distinguir os vários matizes, com grande diferenciação, tornou-se o elemento indispensável aos avaliadores deste trabalho, em todos os quesitos, especialmente na avaliação da cor. A habilidade na percepção das cores aliada à acuidade para detectar outros defeitos, credenciou os examinadores a validar os resultados encontrados.

É muito importante para o sucesso de uma restauração estética a sua estabilidade de cor ao longo do tempo, sendo fundamental o acompanhamento em períodos maiores, uma vez que o interregno determinado na presente pesquisa sinaliza para um comportamento adequado. 
Avaliando restaurações de resina composta em dentes anteriores, por 6 anos, VAN DIJKEN ${ }^{189}$ concluiu que a mudança de cor é tempo-dependente e que varia entre os materiais.

A descoloração dos materiais estéticos à base de resina pode ser causada pelos fatores extrínsecos e intrínsecos ${ }^{3,31,185}$. Os fatores intrínsecos envolvem a descoloração do próprio material resinoso, tais como alteração da matriz resinosa e da interface da matriz e das partículas de carga. A causa da descoloração química tem sido atribuída a mudança ou oxidação do acelerador amina ${ }^{15,18,23,38}$, oxidação na estrutura da matriz polimérica e oxidação dos grupos metacrilatos pendentes ${ }^{31}$, não reagidos ${ }^{190}$. A cor das resinas compostas pode mudar após exposição a várias fontes de energia ${ }^{50}$ e imersão em água por um longo período ${ }^{56,84,85}$. Fatores extrínsecos de descoloração incluem manchamento por adsorção de corantes como resultado da contaminação por fontes exógenas. Manchamentos de materiais poliméricos por soluções corantes ${ }^{87}$, café e chá ${ }^{92}$, nicotina ${ }^{97}$ e refrigerantes ${ }^{108,110}$ têm sido reportados.

A polimerização ocorre por meio de uma série de reações químicas, nas quais uma macromolécula ou um polímero é formado a partir da união de um grande número de moléculas unitárias, chamadas de monômeros. Assim, um monômero significa uma única molécula ou um "mero". Em outras palavras, um grande número de moléculas individuais com baixo peso molecular (meros) de uma ou mais espécies reagem entre si para formar uma única molécula grande e com alto peso molecular ${ }^{133}$.

Nos sistemas fotoativados, fótons de energia luminosa ativam o iniciador e geram radicais livres, os quais iniciam o processo de polimerização. Nas resinas restauradoras odontológicas, a canforoquinona e uma amina irão reagir quando irradiadas pela 
luz visível e, como conseqüência, irão gerar radicais livres ${ }^{133}$.

A resina composta Z-100 apresentou cerca de 3 vezes mais radicais livres do que a Silux Plus e a Heliomolar RO, numa pesquisa de MENEZES; MUENCH ${ }^{112}$ que teve a finalidade de determinar o número relativo desses radicais. Os autores usaram diferentes irradiações $\left(110,180,300\right.$ e $\left.580 \mathrm{~mW} / \mathrm{cm}^{2}\right)$ e diferentes tempos $(10,20,30,40,50$, 60, 80 e 90 segundos) e concluíram que o número de radicais livres aumenta com a intensidade e tempo de exposição.

As aminas terciárias aromáticas presentes nas resinas compostas são componentes muito reativos e a descoloração intrínseca acontece pela oxidação do excesso de amina na massa polimerizada ${ }^{6}$. Segundo ASMUSSEN $^{6}$, esta é a maior causa da descoloração intrínseca das resinas compostas. Nos sistemas polimerizados por luz, uma fonte de luz de $468 \pm 20 \mathrm{~nm}$ excita a canforoquinona ou outra diquetona que interage com a amina terciária não-aromática (alifática) ${ }^{22}$. A canforoquinona, juntamente com a amina terciária inicia uma reação de radical livre ${ }^{3}$. Nenhum estudo tem sido conduzido para determinar se esta combinação produz alguma melhoria ou efeitos a longo prazo na estabilidade da cor $^{3}$.

As resinas fotoativadas requerem muito menos aminas terciárias que as quimicamente ativadas. A estabilidade de cor das fotoativadas é melhorada pelo uso das aminas alifáticas (não-aromáticas). Elas são consideravelmente menos reativas e resultam em menor descoloração intrínseca quando permanecem sem reagir. A maior causa da alteração de cor nos sistemas ativados por luz é a polimerização incompleta, que resulta em iniciadores não reagidos tanto quanto uma porosidade e material solúvel ${ }^{3}$.

Até que ponto este fator atuou negativamente nesta pesquisa alterando a cor de algumas restaurações não se sabe, todavia, é possível que tenha havido 
oxidação das aminas, que porventura estavam presentes em excesso na massa polimerizada das resinas compostas.

Numa avaliação clínica, os hábitos e a dieta dos pacientes podem assumir um papel importante na longevidade das restaurações, principalmente no que diz respeito à alteração na cor. A dieta e os hábitos alimentares podem ter participação na pigmentação extrínseca das restaurações ${ }^{107,185}$, além delas estarem expostas a uma variedade de ácidos, como os produtos dos microorganismos, pela degradação dos alimentos ou os existentes em algumas comidas e bebidas normalmente ingeridas pelos pacientes ${ }^{133}$. Mesmo os hábitos cotidianos como fumar também auxiliam na descoloração da resina composta ${ }^{185}$. UM; RUYTER ${ }^{185}$ referem-se ao mecanismo de descoloração do volume da resina composta dizendo ser pela penetração dos corantes extrínsecos. ROULET ${ }^{142}$ também destacou que, dentre outros fatores, notavelmente o nível de higiene oral influencia muito nos resultados.

A higiene bucal, sem dúvida, é um fator de extrema importância para todas as disciplinas na Odontologia, mantendo a saúde dos tecidos gengivais e dos tecidos duros dentais. Elimina, ainda, os efeitos da permanência dos elementos da dieta nos dentes e restaurações, fazendo com que eles fiquem em contato o mínimo de tempo possível, somente naquele momento em que está sendo ingerido. $\mathrm{O}$ ato da escovação dental tem atuação sobre a película adquirida, principal componente da placa bacteriana. No caso deste trabalho, de uma forma geral, os pacientes mantiveram uma escovação adequada. Naqueles poucos casos em que percebeu-se alteração de cor das restaurações de resina composta, é possível que o tipo da dieta e até pela descurada higienização em alguma oportunidade, não relatadas pelos pacientes, tenham atuado como fatores indutores da descoloração dessas restaurações, pela adsorção e absorção dos corantes. 
As características de superfície têm influência na performance clínica $^{143}$. O tipo de partículas pode, após o polimento, não propiciar uma superfície idealmente lisa, simulando o esmalte ${ }^{98}$. Uma das causas mais prováveis de descoloração entre as resinas compostas é a textura de superfície áspera e porosidade aumentadas ${ }^{102,}{ }^{179}$. A descoloração extrínseca da resina composta se associa ao acúmulo de substâncias depositadas nessas porosidades deixadas por um mau acabamento das restaurações ou pelas porosidades deixadas pelo deslocamento de partículas da resina ${ }^{31}$.

Rugosidades na superfície induzidas pelo processo de acabamento e polimento das restaurações, mesmo que inadvertidamente e ainda que microscópicas, retêm placa bacteriana. Se forem observadas as fotografias deste estudo feitas, por meio da microscopia eletrônica de varredura, das réplicas obtidas pela moldagem das restaurações durante todo o acompanhamento clínico, percebe-se que, por mais criterioso que tenha sido o acabamento e polimento dessas restaurações pequenas ranhuras ou depressões podem ser observadas (Figuras 6.1 a 6.5). O uso dos agentes de cobertura de baixa tensão superficial é importante, visto que preenche os defeitos existentes na superfície e margens das restaurações de resina composta. Este procedimento aumenta a lisura superficial e melhora a resistência ao desgaste, proporcionando restaurações que mantêm um comportamento clínico satisfatório após alguns anos, diminuindo os efeitos da infiltração ${ }^{89}$. No presente trabalho não foi utilizado o selante de superfície para que se analisasse, fundamentalmente, o comportamento clínico dos materiais estudados, sem interferência de outras variáveis que pudessem implicar no desempenho real dos mesmos, ou seja, mascarando ou influenciando características latentes das restaurações.

Portanto, a descoloração anotada nesta pesquisa, embora em 
pequeno índice e dentro dos limites aceitáveis, não pode ser relacionada a um fator isolado, mas sim a um conjunto de fatores que atuam simultaneamente. 
Figura 6.1 - Fotomicrografia do aspecto das restaurações com Z-100 (dente 21 - à esquerda) e com Fill Magic (dente 22 - à direita), com aumento padrão de 40 X (vide página seguinte). 


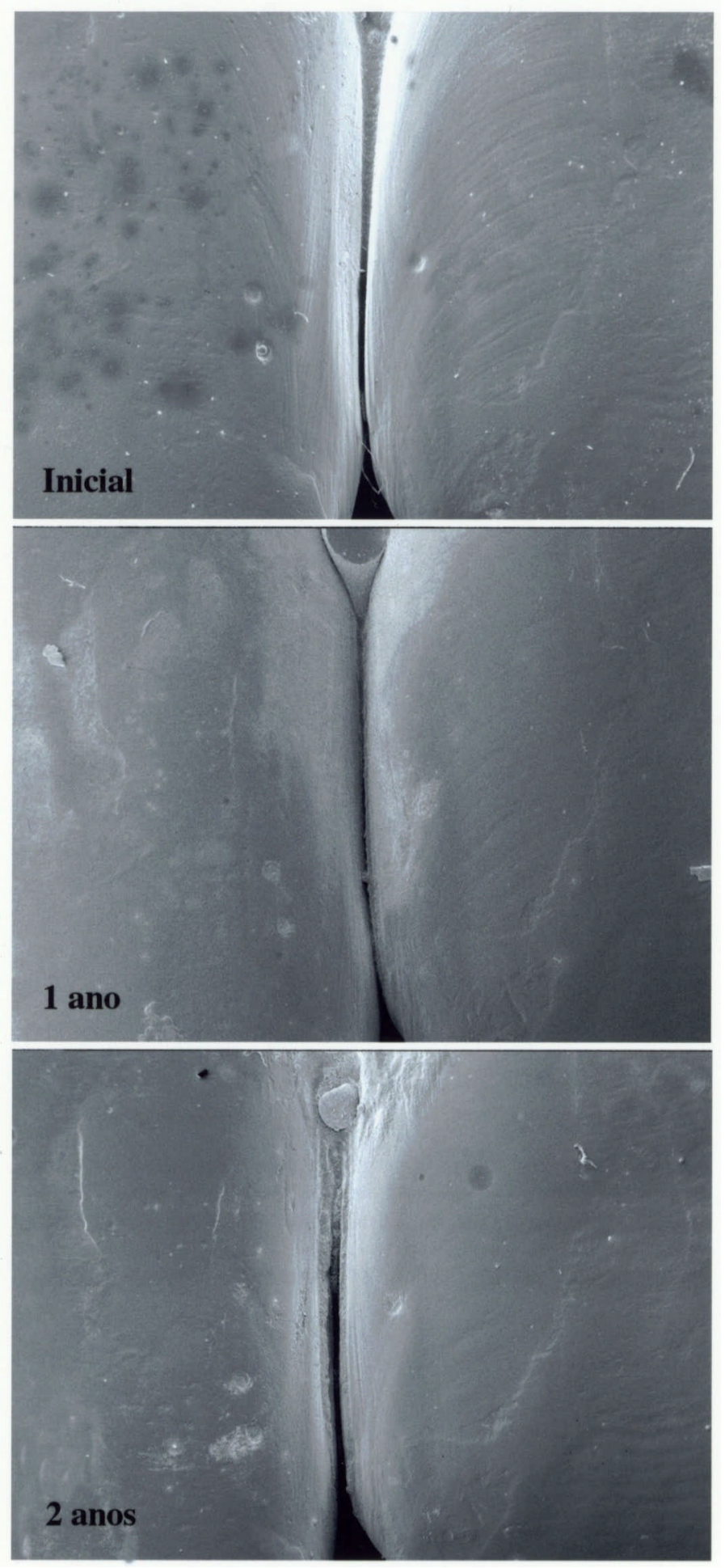


Figura 6.2 - Fotomicrografia do aspecto das restaurações com Z-100 (dente 22 - à direita) e com Fill Magic (dente 21 - à esquerda), com aumento padrão de 40 X (vide página seguinte). 


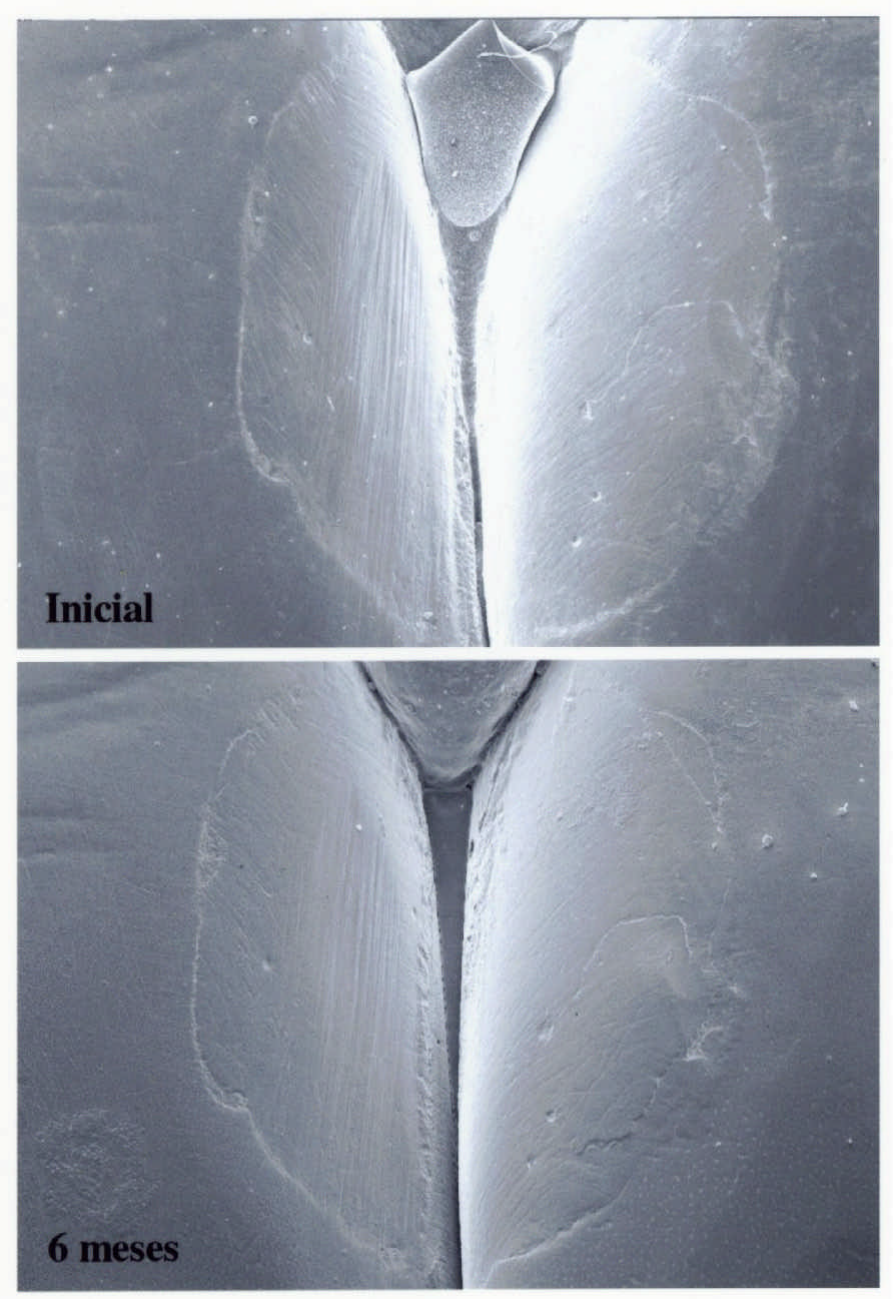


Figura 6.3 - Fotomicrografia do aspecto das restaurações com Z-100 (dente 11 - à direita) e com Fill Magic (dente 12 - à esquerda), com aumento padrão de 40 X (vide página seguinte). 

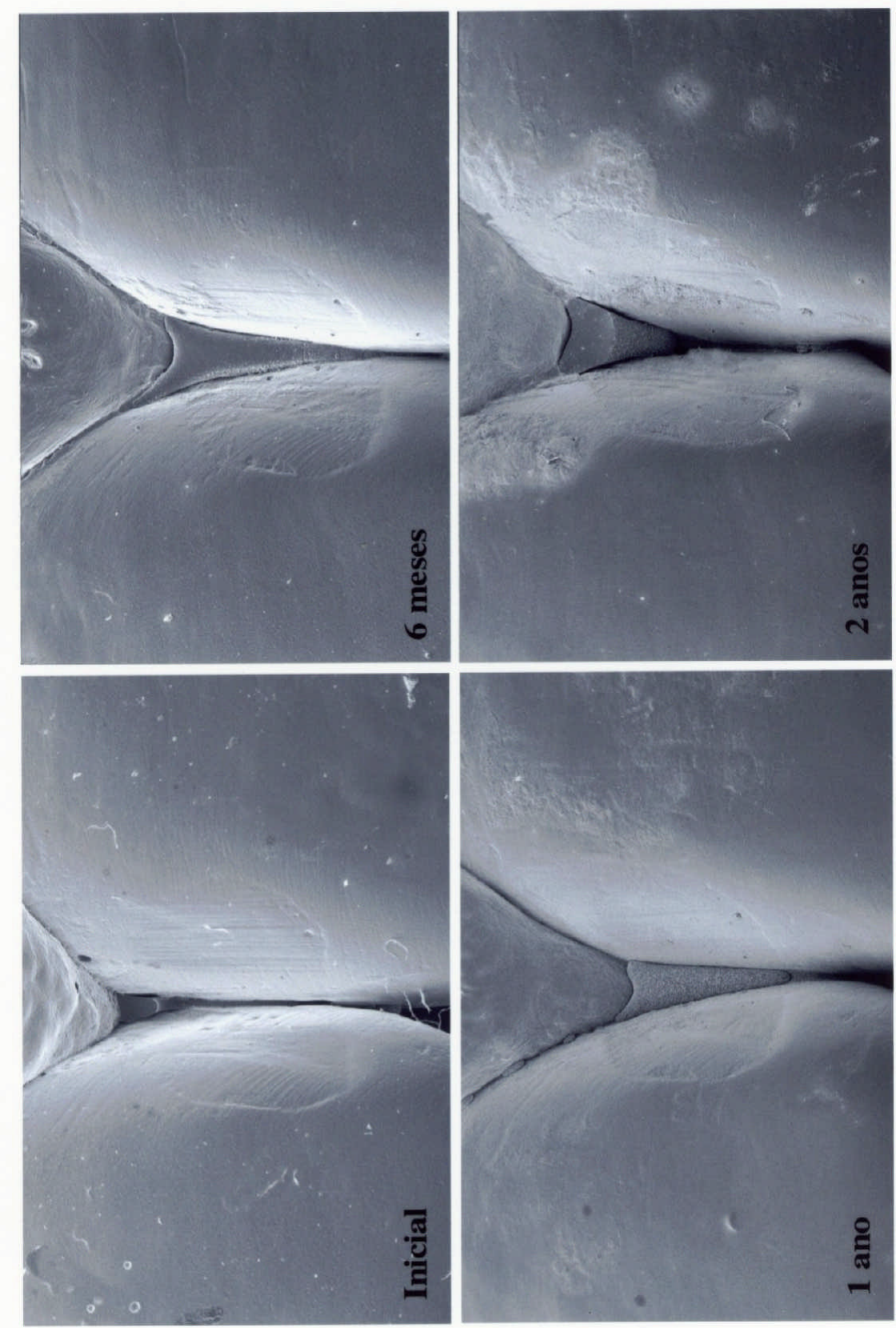
Figura 6.4 - Fotomicrografia do aspecto das restaurações com Z-100 (dente 12 - à esquerda) e com Fill Magic (dente 11 - à direita), com aumento padrão de 40 X (vide página seguinte). 

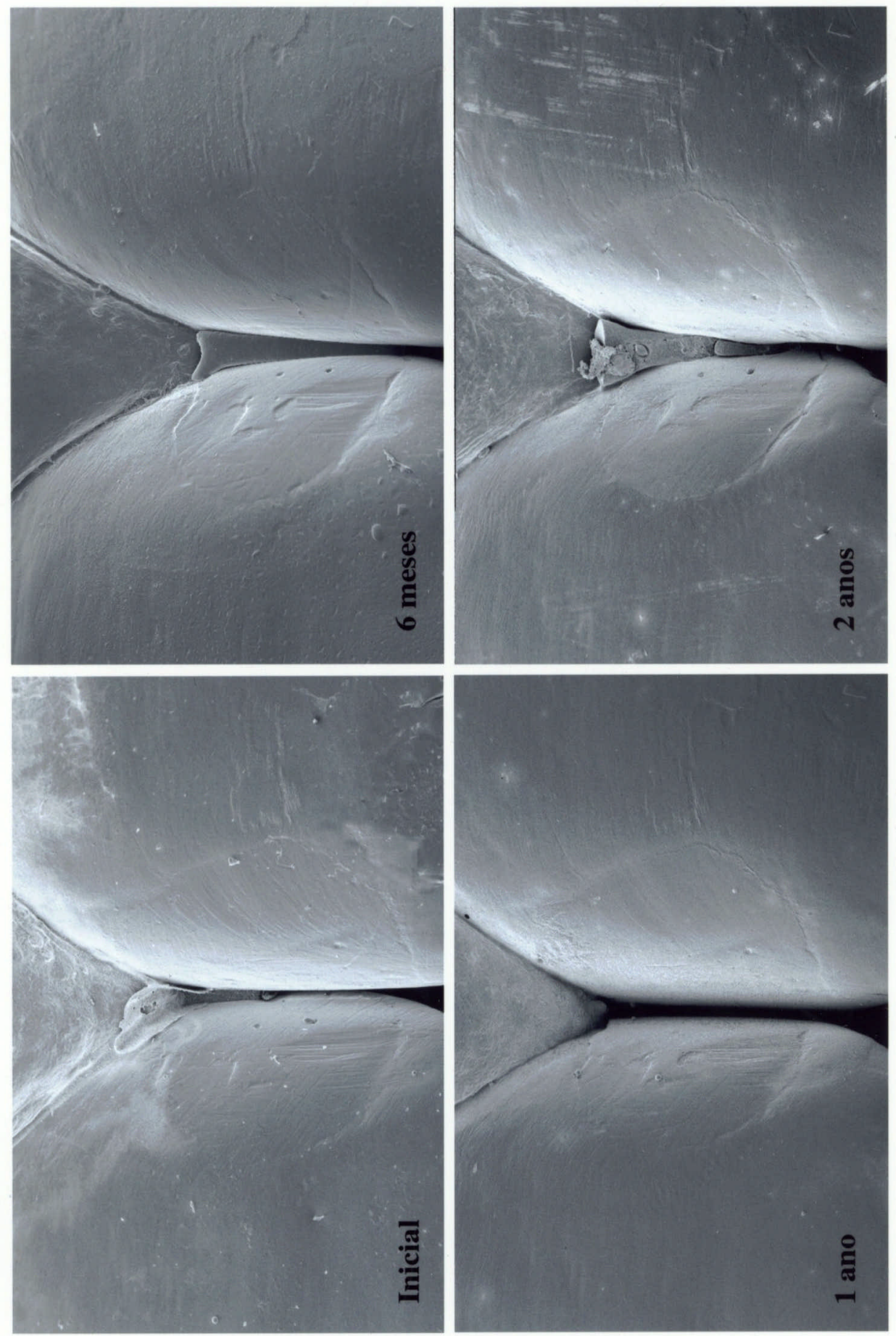
Figura 6.5 - Fotomicrografia do aspecto das restaurações com Z-100 (dente 12 - à esquerda) e com Fill Magic (dente 11 - à direita), com aumento padrão de 40 X (vide página seguinte). 

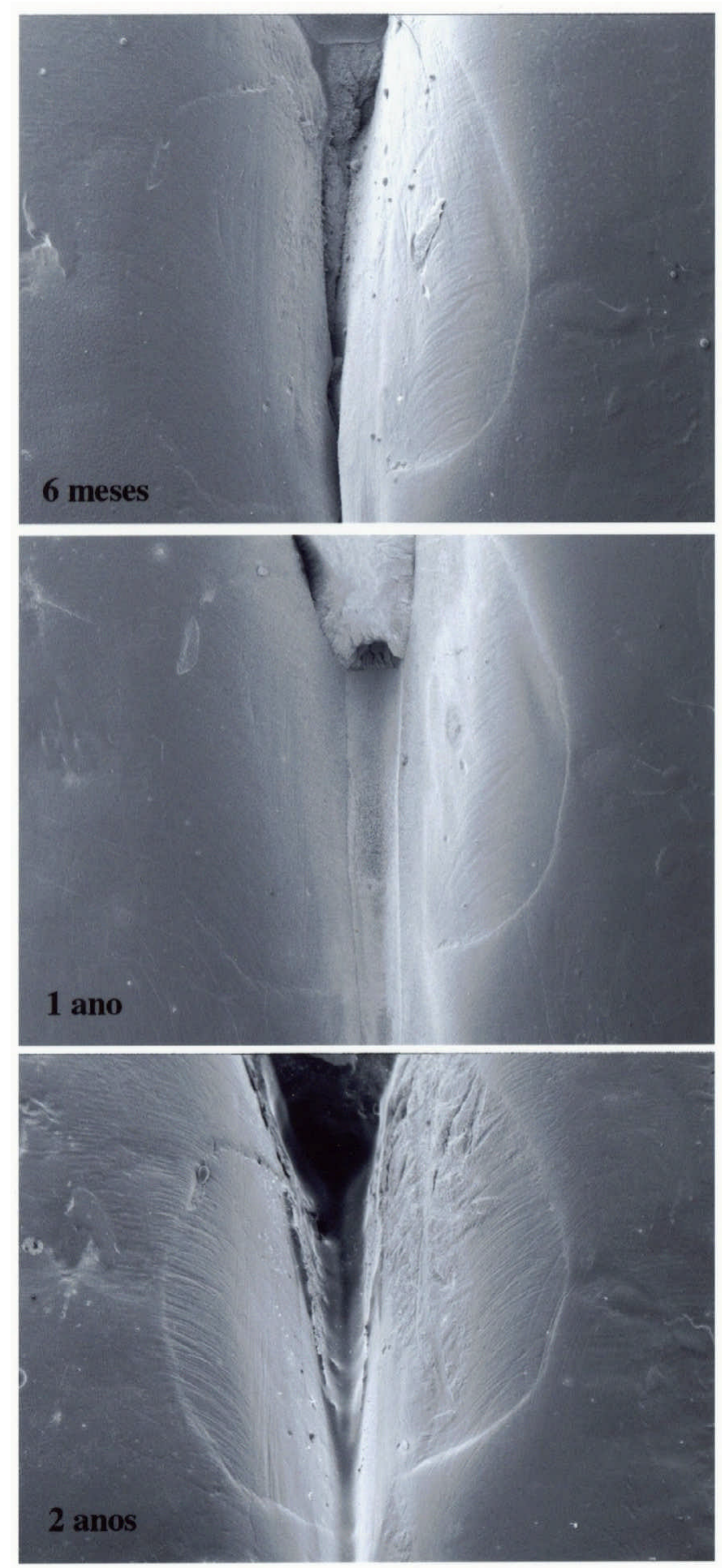
Para ilustrar as causas da alteração de cor, é necessário fazer um preâmbulo sobre a profundidade de polimerização, dando ênfase aos trabalhos dos autores citados a seguir.

BERRY et al. $^{14}$ e LUNDIN; $\mathrm{KOCH}^{104}$ relataram que a profundidade de polimerização inadequada pode prejudicar seriamente a longevidade clínica das restaurações de resina composta. Alcançar adequada profundidade de polimerização de polímeros ativados por luz visível é importante para assegurar propriedades ótimas e, consequentemente, aumentar a vida clínica das restaurações de resina composta ${ }^{83,155}$.

A profundidade de polimerização das resinas compostas ativadas por luz pode variar de acordo com a sua química e a composição das partículas de carga, sua cor e translucência, a concentração do catalisador, a intensidade e potencial de ativação da luz ${ }^{83}$, a distribuição espectral da fonte de luz e a duração da irradiação ${ }^{155}$.

Um nível máximo de polimerização tem sido alcançado nas camadas mais superficiais. É difícil de se alcançar polimerização nas camadas mais internas mesmo estendendo o tempo de irradiação, pois a luz simplesmente não consegue alcançá$\operatorname{las}^{200}$. Uma sólida superfície de resina composta não é uma indicação de polimerização adequada total até o fundo da restauração ${ }^{47,}{ }^{134}$. PILO; CARDASH ${ }^{134}$ destacaram que a polimerização incompleta da massa da restauração é análoga a uma restauração composta de vários materiais diferentes, os quais diferem grandemente em seus valores de módulo de elasticidade. Colocando uma carga sobre a camada superficial bem polimerizada da restauração, a qual cobre uma porção mais profunda incompletamente polimerizada pode causar flexão ou dobramento da camada mais externa e deslocamento interno. Este padrão de deformação predispõe à fratura e fendas marginais e, também, fratura do corpo da 
restauração, perda da forma anatômica e infiltração marginal, com ocorrência de cárie secundária, reações teciduais adversas e irritação pulpar $^{134}$ pela pobre união da resina composta aos tecidos dentais que pode ser causada pelo insuficiente grau de conversão ${ }^{155}$. Conforme DE GEE; TEN HARKEL-HAGENAAR; DAVIDSON ${ }^{46}$ a polimerização incompleta da resina pode ocasionar fratura da massa da restauração, perda da forma anatômica e infiltração marginal e outros possíveis problemas, os quais incluem cárie secundária, reações teciduais adversas e irritação pulpar. Com relação a alteração de cor, a resina composta inadequadamente polimerizada exibirá pobre estabilidade de cor e maior ocorrência de manchas.

As resinas compostas fotopolimerizáveis permitem que seja aplicada a técnica de multicamadas; a técnica de colocação que reduz porosidades pode evitar a desagradável descoloração ${ }^{98}$.

Medindo a dureza da superfície, ONOSE et al. ${ }^{125}$ observaram que com 40 segundos de fotoativação, $1 \mathrm{~mm}$ de resina composta foi polimerizada entre 68 a $84 \%$; com $2 \mathrm{~mm}$, a mesma resina apresentou somente 40 a $60 \%$ de dureza de superfície e com 3 mm, apenas $34 \%$ de dureza. Desse modo, $\operatorname{ALBERS}^{3}$ mencionou que é prudente que se use porções de resina de 1 ou 2 mm, com duração de irradiação de não menos de 40 segundos.

RUEGGEBERG et al. ${ }^{144}$ narrando suas experiências relativas à fotopolimerização das resinas compostas, foram concordantes com $\mathrm{ALBERS}^{3}$ e citaram a espessura da resina composta, como sendo o fator mais importante em seus estudos. A duração e a intensidade da luz foram os próximos mais importantes. Destacaram que incrementos de não mais de $2 \mathrm{~mm}$ deveriam ser sempre utilizados. Na conclusão do trabalho desses autores foi evidenciado que incrementos com espessura de $1 \mathrm{~mm}$ é o ideal. 
A técnica incremental foi utilizada no presente trabalho, com inserção de pequenas porções de resina composta e fotopolimerizadas dentro da padronização estabelecida. Tomando-se por base os diferentes trabalhos reportados acima, certamente eles corroboram para afirmar que a forma anatômica, a integridade marginal, a descoloração marginal, a cárie secundária e a sensibilidade pós-operatória não tenham recebido nenhum escore 1 ou 2.

A pequena alteração da cor das restaurações aqui investigadas, provavelmente não esteja suportada na assertiva da polimerização incompleta da resina composta, relatada pelas pesquisas de DE GEE; TEN HARKEL-HAGENAAR; DAVIDSON $^{46}$, uma vez que a inserção e a fotopolimerização foram criteriosa e adequadamente realizadas, até porque a profundidade de polimerização da resina composta Z100 foi estabelecida no presente trabalho, para incrementos com no máximo 2,0 $\mathrm{mm}$ de espessura. Numa análise da profundidade de polimerização realizada em 1995, SHORTALL; WILSON; HARRINGTON ${ }^{155}$ concluíram que a resina composta Z-100 teve grande profundidade de polimerização com $5,47 \mathrm{~mm}$ para a cor $\mathrm{A}_{2}, 4,71 \mathrm{~mm}$ para a cor $\mathrm{A}_{3,5}$ e 4,86 mm para a cor $C_{2}$. Como todas as porções das diversas cores da resina Z-100 empregadas no presente trabalho nunca excederam a 2,0 mm, obteve-se uma grande margem de segurança na profundidade de polimerização, considerando-se as profundidades mencionadas na pesquisa dos autores acima citados.

É importante lembrar que a profundidade de polimerização está intimamente ligada ao índice de conversão das resinas compostas, que por sua vez está diretamente relacionado com a distância da fonte de luz. O índice de conversão diminui na razão inversa do quadrado da distância da fonte de luz ${ }^{37}$. A distância ideal da fonte de luz é 1 
mm com uma inclinação de $90^{0}$ da superfície da resina composta ${ }^{90}$.

No processo de fotopolimerização ocorre simultaneamente dentro da massa da resina o movimento de moléculas e a liberação de calor. Sabe-se que uma técnica deficiente de polimerização, conduz a um baixo índice de conversão do monômero em polímero, devido ao fato de que a resina composta irá polimerizar-se somente na região que recebeu uma intensidade de luz suficiente, consequentemente haverá a presença de grupos metacrilatos não reagidos, os quais participarão nas ligações químicas para a união das camadas subsequentes de resina ${ }^{133}$. A conseqüência de um baixo índice de conversão devido a uma insuficiência na polimerização é uma descoloração da resina de forma indireta. A pobre conversão das resinas compostas deixa uma grande quantidade de grupos metacrilatos não reagidos no material polimerizado. As duplas ligações carbono-carbono desses grupos metacrilatos pendentes pode levar a matriz polimérica a sofrer reações de degradação ${ }^{188}$. Uma pesquisa de FERRACANE; GREENER ${ }^{59}$ mostrou que a descoloração ocorreu mais provavelmente devido à reação envolvendo os muitos grupos metacrilatos não reagidos (aproximadamente 40\%) presentes dentro da resina. Sob a maioria das circunstâncias, o grau de conversão varia de 60 a $75 \%^{83}$. A profundidade de polimerização é dependente de dois fatores inerentes à resina, que são classificados em extrínsecos e intrínsecos. Os extrínsecos são a distância da fonte e o tempo e os intrínsecos são a composição e o coeficiente de transmissão $^{119}$. O coeficiente de transmissão é um indicador da intensidade de luz que atravessa o composto. As partículas inorgânicas atuam como verdadeiros espelhos refletindo a luz. As resinas de micropartículas, por exemplo, por esta razão possuem maior dispersão da luz, em conseqüência, o coeficiente é mais baixo e a polimerização menos profunda ${ }^{119}$. O que sucede é que as partículas presentes na composição das resinas podem não ter a capacidade de refletir a luz incidida na sua totalidade, impedindo-na de alcançar as porções mais profundas 
da massa resinosa, deixando grupos metacrilatos não reagidos, os quais, presentes dentro da mesma, podem ocasionar a descoloração.

É improvável que isto tenha influído na cor das restaurações deste trabalho, visto que, como já foi mencionado, a polimerização de pequenos incrementos provavelmente não impediu que a irradiação alcançasse os sítios, onde, por ventura, as partículas de carga não tivessem propagado a luz.

Segundo BERRY et al. ${ }^{14}$, para uma adequada polimerização de um material fotopolimerizável, a duração e intensidade da radiação também são importantes. Duração de aplicação é relativamente fácil de controlar, mas a intensidade não é prontamente monitorada. Unidades de luz fotoativadoras geralmente emitem espectro de comprimento de onda entre 400 a $550 \mathrm{~nm}$. Algumas unidades podem ter de pequenas a moderadas quantidades de luz fora desta faixa. Há diferenças na distribuição espectral e intensidade entre as unidades de luz visível comumente disponíveis comercialmente.

Embora as resinas compostas do tipo híbrida, com alto conteúdo de carga, como as usadas neste trabalho, pudessem ter o índice de conversão como justificativa para atuar como fator de modificação da cor da matriz resinosa, devem ser considerados alguns aspectos que limitam esta influência e que foram adotados na presente pesquisa. Pequenas porções de resina foram inseridas nas cavidades, o aparelho de luz fotopolimerizador apresentava-se com uma potência de $520 \mathrm{~mW} / \mathrm{cm}^{2}$, constantemente monitorada por um radiômetro durante os trabalhos. Segundo ALBERS ${ }^{3}$, o comprimento de onda ideal é de $468 \pm 20 \mathrm{~nm}$ e a intensidade mínima de polimerização corresponde a 400 $\mathrm{mW} / \mathrm{cm}^{2}$, o que justifica a aferição semanal dos aparelhos para constatar possíveis alterações nesses valores ${ }^{12}$. Entretanto, segundo dados de pesquisas de LEE; GREENER ${ }^{100}$, a 
intensidade mínima para polimerização da resina composta e/ou dos componentes do adesivo dentinário foi de $250 \mathrm{~mW} / \mathrm{cm}^{2}$. Trabalhando também com intensidade de luz e profundidade de polimerização da resina composta, AZEVEDO; CATRAMBY; FRANCO ${ }^{8}$ concluíram que, embora as orientações dos fabricantes sugerissem o uso das unidades de luz somente acima de $200 \mathrm{~mW} / \mathrm{cm}^{2}$, os valores de profundidade de polimerização obtidos de 100 e $500 \mathrm{~mW} / \mathrm{cm}^{2}$ não foram diferentes um do outro. Abaixo desta média $\left(50 \mathrm{~mW} / \mathrm{cm}^{2}\right)$ e acima $(520-550$ $\mathrm{mW} / \mathrm{cm}^{2}$ ) foram significantemente diferentes. Vale verificar as médias das profundidades, expressas em mm, dos 5 grupos por eles pesquisados: grupo A $\left(50 \mathrm{~mW} / \mathrm{cm}^{2}\right)$ 1,8; grupo B $\left(100-160 \mathrm{~mW} / \mathrm{cm}^{2}\right)$ 3,2; grupo C $\left(200-280 \mathrm{~mW} / \mathrm{cm}^{2}\right)$ 3,4; grupo D $\left(480-500 \mathrm{~mW} / \mathrm{cm}^{2}\right)$ 3,9 e grupo E $\left(520-550 \mathrm{~mW} / \mathrm{cm}^{2}\right)$ 6,3. A potência do aparelho utilizado nesta pesquisa pode até ser enquadrada no grupo E, supondo que atingiu uma profundidade de polimerização de 6,3 mm, além disso, a distância nos primeiros 10 segundos de fotopolimerização, para diminuir as tensões geradas pela contração de polimerização na interface dente/restauração, foi de alguns centímetros. Após esse tempo, a aproximação foi de cerca de $1 \mathrm{~mm}$ do incremento completando-se a duração de irradiação dos 40 segundos para cada porção de resina. Essa manobra era realizada naqueles preparos cavitários em que não era possível usar a estrutura dental como interposição nos primeiros segundos de fotoativação. Em seus trabalhos de pesquisa, VERSLUIS; DOUGLAS; SAKAGUCHI ${ }^{193}$ utilizaram uma fonte de luz com 500 $\mathrm{mW} / \mathrm{cm}^{2}$ de potência para polimerizarem suas amostras e a ponta da fonte foi posicionada a aproximadamente $1 \mathrm{~mm}$ delas, assegurando alto grau de conversão.

Outro aspecto que tem sido considerado na literatura com relação à alteração de cor é a presença de bolhas de ar na resina composta que podem levar a zonas de inibição de polimerização, resultando em baixa estabilidade, conforme trabalho de KHOKHAR; RAZZOOG; YAMAN ${ }^{91}$. Deve-se dar atenção também a esse aspecto ao se 
tentar analisar as prováveis causas da alteração de cor das resinas compostas. A afirmação desses autores é bastante pertinente, visto que o oxigênio em contato com a resina composta, inibe a polimerização, competindo com ela ${ }^{3}$, levando, na verdade, a áreas incompletamente polimerizadas, que por conseguinte geram a instabilidade de cor tão indesejada. No presente trabalho, ainda que pequenas porções de resina tivessem sido inseridas no preparo cavitário, a incorporação de bolhas de ar, mesmo microscópicas, era praticamente inevitável, e poderiam se alojar na massa da resina, cujo controle escapa à qualquer operador. Assim, talvez fosse sensato incluir esse fator nas causas que possivelmente tenham colaborado no processo de mudança de cor de algumas restaurações, durante esses 2 anos de observação, em ambas as resinas compostas comparadas.

A luz ultravioleta também pode influenciar na estabilidade de cor das resinas compostas. Assim, FERRACANE; MOSER; GREENER ${ }^{60}$, estudaram este processo utilizando 5 resinas dentais à base de Bis-GMA (4 quimicamente ativadas e 1 fotoativada) iluminando-as com luz ultravioleta por vários períodos de tempo. Embora a fonte de ultravioleta usada pelos autores fosse levemente diferente da luz solar natural, menos de 24 horas de iluminação (equivalente a aproximadamente 6 semanas de exposição à luz natural do sol) foi suficiente para causar uma descoloração muito significante nessas resinas. A alteração visual do Bis-GMA, por si próprio, durante a iluminação dos raios ultravioleta, na presença de oxigênio, implica que alguma modificação química da própria resina composta pode ser uma das principais causas da descoloração desse material restaurador ${ }^{60}$, muito embora, na sua composição, existam os absorvedores dessa luz ${ }^{3}$.

Este aspecto merece destaque, uma vez que as resinas compostas objetos do presente estudo certamente possuem na sua formulação absorvedores da luz 
ultravioleta, que impedem a atuação da mesma sobre as restaurações. Estas permanecem constantemente expostas aos raios ultravioleta dos vários tipos de luz, seja a natural (solar) ou a luz proveniente de lâmpadas incandescentes e fluorescentes, comuns na iluminação das residências, consultórios ou outros ambientes. Isto sugere que a perda da estabilidade da cor de algumas restaurações, que receberam escores 1 (um), desta pesquisa, não tenha ocorrido por ação da incidência da luz ultravioleta. As restaurações de resina composta são mais suscetíveis ao manchamento, descoloração e retenção de placa, especialmente com pessoas que fumam, bebem chá ou café e tem pobre higiene bucal ${ }^{171}$. Segundo UM; RUYTER ${ }^{185}$, a descoloração causada pelo chá pode ser facilmente removida. Esta descoloração removível acontece devido à adsorção dos corantes do chá na superfície das resinas compostas. Atribuise a descoloração pelo café à adsorção e à absorção dos corantes nele existentes. Os corantes do café penetram mais profundamente nos materiais, provavelmente porque são mais compatíveis com as matrizes poliméricas das resinas compostas ${ }^{185}$.

DAVIS; MAYHEW ${ }^{45}$ numa comparação clínica de 3 resinas compostas (uma convencional - Concise; uma de micropartículas quimicamente ativada Silar e uma de partículas pequenas fotopolimerizável - Prisma Fil), a cor foi a categoria na qual todos os materiais tiveram uma deterioração grande, com alteração de escores ALFA de 1 ano para 3 anos. Nos exames "baseline" e 1 ano obtiveram perto de $100 \%$ de escores ALFA e na avaliação de 3 anos os resultados indicaram que os escores BRAVO aumentaram aproximadamente 40 a 50\% em cada grupo. O teste estatístico exato de Fisher, também usado por esses autores, entretanto, não mostrou diferenças estatisticamente significantes na cor entre as 3 resinas compostas ao final dos 3 anos.

Os dados observados neste trabalho concordam com os de DAVIS; 
MAYHEW $^{45}$ no que se refere ao "baseline" e um ano de observação.Embora esses autores tenham feito um acompanhamento por 3 anos, a cor foi, também, o item em que as 2 resinas compostas avaliadas na presente pesquisa, apesar de formulação mais recente, tiveram diminuição dos escores 0 (zero) de 1 ano para 2 anos. No "baseline", das 70 restaurações verificou-se que as $35(100 \%)$ realizadas com a resina composta Fill Magic receberam escores zero. Quanto as 35 com a Z-100, uma (2,9\%) restauração recebeu escore 1 e as demais $(97,1 \%)$ receberam escores zero. No retorno dos 6 meses, foram avaliados o mesmo total de restaurações e para as $35(100 \%)$ da Fill Magic atribuíram-se escores zero, enquanto para a resina Z-100, $31(88,6 \%)$ receberam escores zero e quatro $(11,4 \%)$ escores 1 . Na avaliação de 1 ano, as porcentagens repetiram-se para a Z-100. Já para a Fill Magic, somente 1 restauração $(2,9 \%)$ recebeu escore 1 e as demais $34(97,1 \%)$ escores zero. Aos 2 anos, repetiram-se as porcentagens para a resina Fill Magic. Para a Z-100, 32 restaurações $(91,4 \%)$ foram consideradas escores zero e $3(8,6 \%)$ levaram o escore 1 . O teste estatístico exato de Fisher, também utilizado nesta pesquisa, igualmente não mostrou diferenças estatisticamente significantes na cor entre as 2 resinas compostas ao final dos 2 anos. Justifica-se essa ausência de significância estatística entre as duas resinas comparadas, possivelmente pelo fato de, basicamente, ambas apresentarem BISGMA e TEGDMA como componentes orgânicos e quantidades muito semelhantes de componentes inorgânicos.

Verificando as porcentagens da resina composta Z-100, observa-se que no exame dos 2 anos a porcentagem de escores 1 (um) diminuiu em relação à avaliação de 1 ano. Das 4 restaurações que receberam escores 1 (um) na observação de 1 ano, aos 2 anos, somente 3 receberam este escore e uma voltou a obter escore 0 (zero). Este último aspecto pode, hipoteticamente, relacionar-se ao efeito "camaleônico", ou seja, a capacidade que a restauração possui de adquirir a coloração da estrutura dentária adjacente ${ }^{171}$, ou devido a 


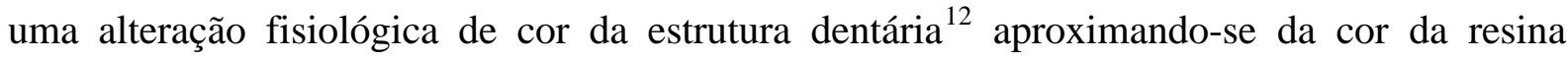
composta, justificando possivelmente, esse resultado observado pelos avaliadores.

O escore 1, para a cor, anotado pelos examinadores para uma restauração com a resina composta Z-100, no "baseline", pode possivelmente ser explicado pela ação dos fatores extrínsecos como a ação dos corantes presentes na dieta alimentar, além de um fator agravante muito importante que é o cigarro, do qual o paciente fazia uso.

O tempo de acompanhamento de 2 anos também foi utilizado por RIBBONS; PEARSON ${ }^{141}$ em pesquisa clínica, na qual confeccionaram mais de 200 restaurações com a resina composta Adaptic e ao final perceberam que houve evidência de uma leve mudança de cor, geralmente um escurecimento, de cerca de $20 \%$ das amostras, mas a cor foi ainda aceitável tanto para o paciente quanto para o operador. As demais restaurações permaneceram com sua cor original. Analisando esse trabalho, embora os autores tenham usado resina quimicamente ativada, percebe-se uma semelhança com o presente estudo, já que a alteração foi na cor e as restaurações permaneceram dentro do limite aceitável, denotando assim, que mesmo com o advento de resinas compostas com maior aprimoramento tecnológico, mantém-se a tendência natural das resinas sofrerem alteração de cor, em função de fatores intrínsecos e extrínsecos.

ABDALLA; ALHADAINY² (1996) acompanharam por 2 anos 120 restaurações de classe I, feitas com 4 resinas compostas (Z-100/3M, HerculiteXR/Kerr, Clearfil Photo Posterior/Kuraray e Heliomolar RO/Vivadent). Aos 2 anos, 104 (87\%) das 120 restaurações iniciais puderam ser avaliadas e concluíram que as resinas compostas Z-100 e Herculite XR revelaram ser significantemente mais estáveis na cor que as outras 2 resinas testadas. A resina composta Z-100, especialmente, obteve $98 \%$ de escores Alfa e $2 \%$ de 
escores Bravo, com relação à cor. De acordo com os autores, isto pode ser explicado pela presença de partículas menores nos materiais, as quais diminuem a rugosidade e a mudança de cor $^{3}$. Comparando os resultados da presente pesquisa com a dos citados autores, verificou-se resultados semelhantes com relação à estabilidade da cor da resina Z-100, embora tenham trabalhado com restaurações de classe I.

Num estudo de VAN NOORT; DAVIS ${ }^{192}$, onde trabalharam com resinas compostas ativadas quimicamente, ao final de 5 anos, de 2399 classes III, 23,8\% apresentaram alteração de cor, $14,7 \%$ estavam com cárie recorrente, $12,4 \%$ tinham problemas com a integridade marginal e em $6,4 \%$ a forma anatômica estava alterada. Os resultados desse trabalho, mesmo sendo com resinas quimicamente ativadas, reafirmam, igualmente, o comportamento inerente tanto de resinas compostas ativadas quimicamente como fisicamente, de sofrerem alteração de cor. Provavelmente, essa alteração esteja mais relacionada, entre outros fatores, com os cuidados e hábitos dos pacientes, uma vez que a maioria deles apresenta, nos diferentes trabalhos clínicos, inclusive este, um desempenho clínico adequado com relação à estabilidade de cor.

Numa época como a que vivemos, de extrema competitividade comercial, de sigilo tecnológico e, também, de espionagem industrial, onde os meios de comunicação induzem a um consumo irracional (a ponto dos próprios pacientes solicitarem determinado produto comercial, no seu tratamento) os Cirurgiões-Dentistas devem estar prevenidos contra as consequências desses fatos; por outro lado, há indicações de que certos produtos são lançados no comércio sem que estejam ainda suficientemente desenvolvidos tecnologicamente e testados clínica e cientificamente. Portanto, o profissional deve lembrar-se de que usar produtos novos, não suficientemente testados, pode significar que ele próprio irá 
fazer, do seu paciente um laboratório de teste de qualidade ${ }^{194}$.

A necessidade de se avaliar materiais restauradores dentais continuará. Vários métodos estão disponíveis para proporcionar informações em diferentes níveis de precisão. Novos instrumentos tais como câmeras intra-orais e imagens computadorizadas ajudarão ao potencial dos pesquisadores para proporcionar informações inovadoras $^{95}$. Talvez as avaliações anuais ou semestrais serão realizadas em casa por meio de um pequeno dispositivo de imagem intra-oral conectado a um computador pessoal e modem. Assim, informações do paciente poderão ser transmitidos para o banco de dados do profissional, onde as novas imagens seriam automaticamente comparadas com imagens do "baseline" armazenadas e analisadas pela subtração radiográfica ou imagem similar. Diagnóstico e prescrição de tratamento poderão ser, então, transmitidos de volta para o paciente e a equipe auxiliar na clínica $\operatorname{local}^{82}$. A avaliação clínica do século 21 , muito provavelmente, poderá ser feita usando provas computadorizadas e dispositivos para escaneamento, subtração de imagens e sensores eletro-químicos.

Todavia, JENDRESEN ${ }^{82}$ foi muito feliz ao externar sua opinião em relação a pesquisa clínica no próximo século: "no século 21, a performance clínica das resinas compostas será julgada, muito provavelmente pelo mesmo critério geral que foi proposto pelo Professor Gunnar Ryge, 30 anos atrás”. Trata-se de um método de avaliação largamente usado, barato, que pode ser realizado em ambiente acadêmico ou em clínica privada e que tem demonstrado ser muito eficaz com resultados confiáveis, desde que feito com bastante critério, bom senso e responsabilidade. Método este, aliás, que adaptado, foi utilizado neste estudo. 
7 CONCLUSÕES 


\section{CONCLUSÕES}

- No período de 2 anos, a resina composta Fill Magic mostrou comportamento clínico semelhante à resina Z-100.

- $\mathrm{O}$ aspecto cor foi o fator que evidenciou alguma alteração no comportamento clínico das restaurações, quando comparado aos demais ítens pesquisados.

- As duas resinas compostas demonstraram excelente comportamento clínico nas categorias avaliadas, tornando-as adequadas para uso em restaurações de dentes anteriores. 
ANEXOS 
Anexo 1 - Ficha clínica utilizada na primeira sessão de atendimento dos pacientes

PACIENTE N.:

FACULDADE DE ODONTOLOGIA DE BAURU - USP

DEPARTAMENTO DE DENTÍSTICA - FOB

Avaliação clínica de restaurações de classe III com as resinas compostas Fill Magic e Z100

Paciente:

Responsável:

Endereço:

Telefone:

Idade:

Contato:

N.:

Sexo: $\square \mathrm{M} \quad \square \mathrm{F}$

RESTAURAÇÕES / LOCALIZAÇÃO:

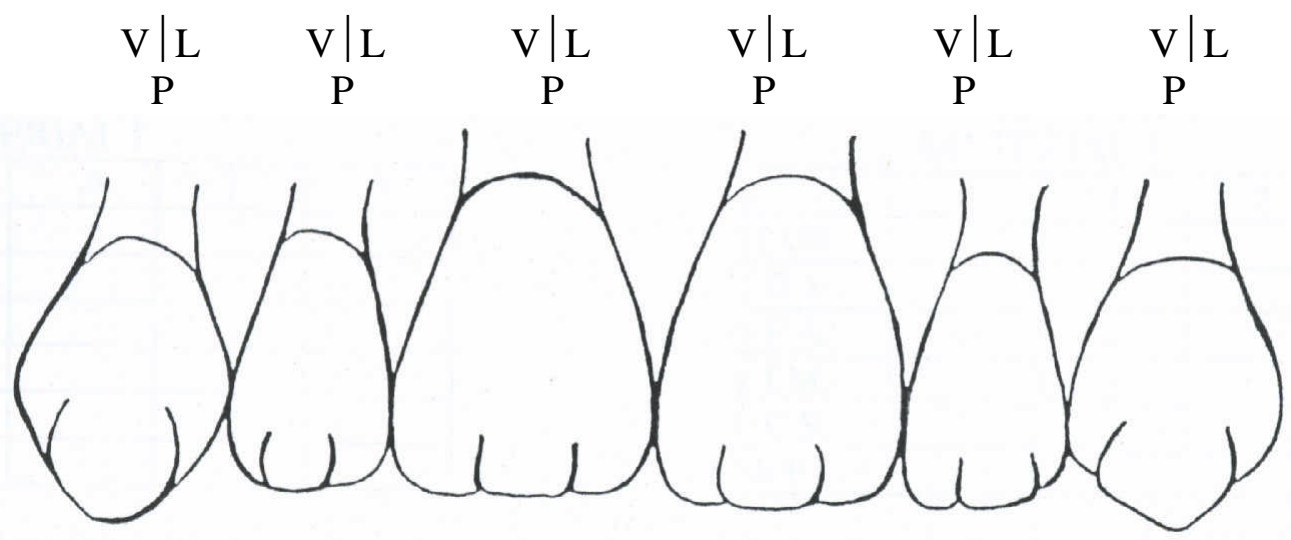

Data de execução:

\section{CÓDIGOS DOS MATERIAIS EMPREGADOS:}

Fill Magic - Vigodent $=\mathrm{F}$

$\mathrm{Z}-100-3 \mathrm{M}=\mathrm{Z}$

OBS: 
Anexo 2 - Ficha clínica utilizada nos retornos dos pacientes

Avaliação clínica de restaurações de classe III com as resinas compostas Fill Magic e Z100

AVALIAÇÃO N.: MESES

DATA:

PACIENTE:

N.:
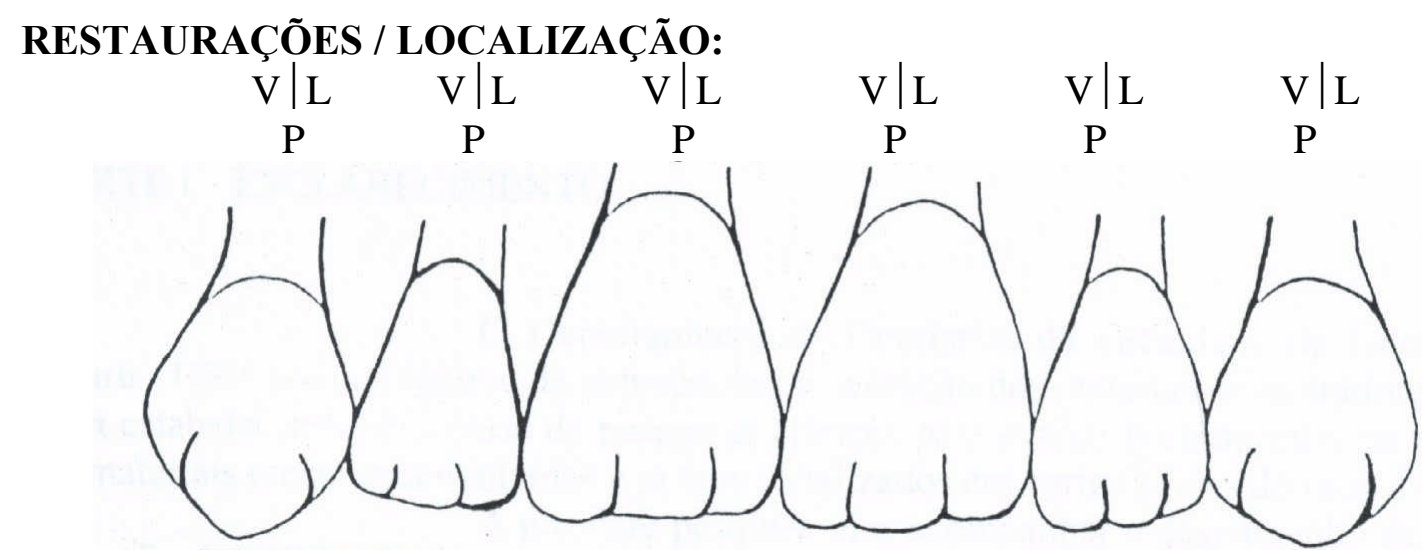

EXAMINADOR 1
MATERIAL F
\begin{tabular}{|l|c|c|c|}
\hline & 0 & 1 & 2 \\
\hline COR & & & \\
\hline D.M. & & & \\
\hline F.A. & & & \\
\hline I.M. & & & \\
\hline C.S. & & & \\
\hline S.P.O. & & & \\
\end{tabular}

\section{EXAMINADOR 2}

MATERIAL F

EXAMINADOR 1

MATERIAL Z

\begin{tabular}{|l|l|l|l|}
\hline & 0 & 1 & 2 \\
\hline COR & & & \\
\hline D.M. & & & \\
\hline F.A. & & & \\
\hline I.M. & & & \\
\hline C.S. & & & \\
\hline S.P.O. & & & \\
\hline
\end{tabular}

\begin{tabular}{|l|l|l|l|}
\hline & 0 & 1 & 2 \\
\hline COR & & & \\
\hline D.M. & & & \\
\hline F.A. & & & \\
\hline I.M. & & & \\
\hline C.S. & & & \\
\hline S.P.O. & & & \\
\hline
\end{tabular}

EXAMINADOR 2

MATERIAL Z

\begin{tabular}{|l|l|l|l|}
\hline & 0 & 1 & 2 \\
\hline COR & & & \\
\hline D.M. & & & \\
\hline F.A. & & & \\
\hline I.M. & & & \\
\hline C.S. & & & \\
\hline S.P.O. & & & \\
\hline
\end{tabular}

\section{OBSERVAÇÕES:}

$\square$ Perda da restauração $\square$ Restauração envolvida por outra $\square$ Perda do dente $\square$ Não compareceu $\square$ Mudou de endereço (não há contato) $\square$ Outras obs.

Registros fotográficos: Fotos n.:

Filme n.: 
Anexo 3 - Documento de esclarecimento, aos pacientes ou responsáveis, sobre a pesquisa clínica - Parte I (continua no anexo 4)

UNIVERSIDADE DE SÃO PAULO

FACULDADE DE ODONTOLOGIA DE BAURU

DEPARTAMENTO DE DENTÍSTICA

\section{DOCUMENTO DE ESCLARECIMENTO E ACEITAÇÃO PARA PARTICIPAÇÃO EM PESQUISA CLÍNICA}

\section{PARTE I - ESCLARECIMENTO}

O Departamento de Dentística da Faculdade de Odontologia de Bauru - USP, com o objetivo de acompanhar a evolução dos materiais restauradores dentários, vem estabelecendo uma série de pesquisas clínicas para avaliar o comportamento, "in vivo", de materiais recém desenvolvidos e já comercializados em vários países do mundo.

A presente pesquisa visa acompanhar o desempenho de uma resina composta (Fill Magic) comparando-a com outra resina composta já existente no mercado odontolófico (Z-100), empregando-as em restaurações de dentes anteriores, com envolvimento estético e monitorando-as por um período de 2 anos, com intervalos de avaliação de 6,12 e 24 meses.

Vale ressaltar que estes materiais não representam quaisquer riscos biológicos aparentes e/ou relativos, quando comparados com outros materiais semelhantes ou afins, estes já amplamente usados e aprovados para o uso na clínica diária.

Destacamos ainda, que quaisquer falhas que os materiais venham, porventura, apresentar, durante o período de avaliação, as quais indiquem a necessidade de uma nova restauração ou reposição de restauração perdida, esta será refeita ou reposta, pelo mesmo operador (profissional) que a executou, empregando os mesmos materiais, quando a falha não for inerente ao mesmo, ou por outro material, já comprovadamente aceito como indicado para tal, quando o primeiro material mostrar-se inadequado.

Os pacientes participantes da pesquisa, terão direito, quando solicitado, a um comprovante (atestado) de comparecimento ao atendimento clínico, para fins de justificativa de falta junto à escola ou ao trabalho, de acordo com os preceitos estabelecidos pela Lei 5081, no seu Artigo $6^{0}$ (25/08/66). 
Anexo 4 - Documento de aceitação, pelos pacientes ou responsáveis, em participarem da pesquisa clínica - Parte II

\section{PARTE II - ACEITAÇÃO PARA A PESQUISA}

$\mathrm{Eu}$, ,por

tador(a) do RG n. , declaro para os devidos fins, que de acordo com os esclarecimentos acima estabelecidos, aceito, espontaneamente, participar da pesquisa clínica para avaliação de um material restaurador estético/adesivo (resina composta), consciente de que o mesmo pode, eventualmente, não apresentar um comportamento clínico considerado satisfatório, dentro de um determinado espaço de tempo (6 a 24 meses). Nesta eventualidade e de acordo com o acima expresso, terei o direito à substituição da restauração, num curto espaço de tempo (máximo de 15 dias), pelo mesmo material ou um equivalente estético, sem ônus ou outras pendências, a ser realizada pelo mesmo profissional que realiza a pesquisa ou seu substituto autorizado.

Declaro que não me cabe qualquer contestação ética, pública e/ou jurídica, quanto ao procedimento do profissional, ou relativa à Instituição (FOB-USP), pelo emprego dos materiais, seu comportamento clínico e sua durabilidade, tendo em vista o exposto neste documento.

Desta forma, assumo o compromisso pessoal e moral, de comparecer rotineiramente, a cada período de avaliação, de acordo com o estabelecido na citada pesquisa $(6,12,24$ meses), quando solicitado, através de carta, recado, contato telefônico ou contato pessoal, devendo submeter-me aos procedimentos de avaliação (exame clínico, fotografias, moldagens) nos dias e hora determinados, podendo requerer um documento comprobatório do meu comparecimento para fins de justificativa trabalhista ou escolar.

Bauru, _L_ _ _

Paciente / Responsável (menor):

RG n.:

Profissional:

Profa. Dra. Maria Fidela de Lima Navarro/Prof. Dr. Eduardo Batista Franco

Professores responsáveis (FOB-USP) 


\section{REFERÊNCIAS BIBLIOGRÁFICAS}




\section{REFERÊNCIAS BIBLIOGRÁFICAS*}

1. ABELL, A. K.; LEINFELDER, K. F.; TURNER, D. T. Microscopic observations of the wear of a tooth restorative composite in vivo. Biomed. Mater., v.17, n.3, p.501-7, May 1983.

2. ABDALLA, A. I; ALHADAINY, H. A. 2-year clinical evaluation of class I posterior composites. Amer. J. Dent., v.9, n.4, p.150-2, Aug. 1996.

3. ALBERS, H. F. Tooth-colored restoratives: an introductory text for selecting, placing and finishing direct systems. 8.ed. Santa Rosa, Alto Books, 1996. Cap.5a, p.1-8; Cap. $5 b$, p.1-10.

4. AKER, J. R. New composite resins: comparison of their resistance to toothbrush abrasion and characteristics of abraded surfaces. J. Amer. dent. Ass., v.105, n.4, p.633-5, Oct. 1982.

5. ASMUSSEN, E. An accelerated test for color stability of restorative resins. Acta odont. scand., v.39, n.6, p.329-32, 1981 apud UM; RUYTER ${ }^{185}$ p.377.

6. ASMUSSEN, E. Clinical relevance of physical, chemical, and bonding properties of composites resins. Oper. Dent., v.10, p.61-73, 1985.

\footnotetext{
*Normas recomendadas para uso no âmbito da Universidade de São Paulo, com base no documento "Referências Bibliográficas: exemplos". Emanado do Conselho Supervisor do Sistema Integrado de Bibliotecas da USP, reunião de 20 de setembro de 1990.
} 
7. ASMUSSEN, E.; JÖRGENSEN, K. D. A microscopic investigation of the adaptation of some plastic filling materials to dental cavity walls. Acta odont. scand., v.30, n.1, p.3-21, 1972 apud HANSEN; ASMUSSEN ${ }^{76}$ p.122, 125, 126.

8. AZEVEDO, L. R.; CATRAMBY, M. F.; FRANCO, E. B. Interrelation of light intensity depth of cure and curing units. J. dent. Res., v.76, p.324, 1997. Special issue. /Abstract 2481/

9. BARREIROS, I. D.; ARAÚJO, P. A.; NAGEM FILHO, H. Eficiência do sistema adesivo em restaurações com resina composta, com determinados períodos de acabamento e polimento. Rev.Fac.Odont.Bauru, v.2, n.2, p.8-13, abr./jun.1994.

10. BATITUCCI, M. H. G. Avaliação da adaptação marginal de resinas compostas em cavidades dentinárias submetidas a diferentes sistemas adesivos. Bauru, 1991. 116p. Dissertação (Mestrado) - Faculdade de Odontologia de Bauru, Universidade de São Paulo.

11. BAUSCH, J. R. et al. In vivo measurement of color and discoloration of composite materials with a new colorimeter. J. dent. Res., v. 60, p.1213, 1981. Special issue B. /Abstract 58/

12. BAYNE, S. C.; HEYMANN, H. O.; SWIFT JUNIOR, E. J. Update on dental composite restorations. J. Amer. dent. Ass., v.125, n.6, p. 687-701, June 1994.

13. BERASTEGUI, E. et al. Surface roughness of finished composite resins. J. prosth. Dent., v.68, n.5, p.742-9, Nov. 1992.

14. BERRY, J. G. et al. Measurement of intensity of curing light units in dental offices. $\mathbf{J}$. dent. Res., v.71, p.161, 1992. Special issue. /Abstract 442/ apud SHORTALL; WILSON; HARRINGTON ${ }^{155}$ p.341. 
15. BLANK, L. W. et al. The gingival response to wellfinish composite resin restorations. Oper. Dent., v.42, n.6, p.626-32, 1979.

16. BOWEN, R. L. Properties of a silica-reinforced polymer for dental restorations. J. Amer. dent. Ass., v.66, p.57-64, Jan. 1963.

17. BOWEN, R. L; RAPSON, J. E.; DICKSON, G. Hardening shrinkage and hygroscopic expansion of composite resins. J. dent. Res., v.61, n.5, p.654-8, May 1982 apud HANSEN; ASMUSSEN ${ }^{76}$ p.122, 126.

18. BOWEN, R. L. et al. Theory of polymer composites. In: VANHERLE, G.; SMITH, D. C. International Symposium on Posterior Composite - Resin Dental - Restorative Materials. Netherlands, Peter Szulc Publishing, 1985. Section II, p.95-105.

19. BOYDE, A.; KNIGHT, P. J. The use of scanning electron microscopy in clinical dental research. Brit. dent. J., v.127, n.7, p.313-22, Oct. 1969.

20. BOZELL, R. R.; CHARBENEAU, G. T. Clinical evaluation of unetched, etched and etched-bonded Class 3 and 5 composite restorations. J. dent. Res., v.58, p.330, 1979. Special issue A./ Abstract 954/

21. BRADEN, M.; CAUSTON, E. E.; CLARKE, R. L. Diffusion of water in composite filling materials. J. dent. Res., v.55, n.5, p.730-2, Sept./Oct. 1976 apud HANSEN; $\operatorname{ASMUSSEN}^{76}$ p 122, 126.

22. BRAEM, M.; LAMBRECHTS, P.; VAN DOREN, V.; VANHERLE, G. The impact of composite structure on its elastic response. J. dent. Res., v.65, n.5, p.648-53, May 1986.

23. BRÄNNSTRÖM, M. Composite resin restorations: biological considerations with special reference to dentin and pulp. In: VANHERLE, G.; SMITH, D. C. International 


\section{Symposium on Posterior Composite - Resin Dental - Restorative Materials.}

Netherlands, Peter Szulc Publishing, 1985. Section II, p.71-82.

24. BRÄNNSTRÖM, M. The hydrodynamic theory of dentinal pain: sensation in preparations, caries and the dentinal crack syndrome. J. Endod., v.12, n.10, p.453-7, Oct. 1986.

25. BROWNING, W. D.; DENNISON, J. B. A survey of failure modes in composite resin restorations. Oper. Dent., v.21, n.4, p.160-6, July/Aug. 1996.

26. BRYANT, R. W.; RESS, F. T.; ROSS, I. D. Clinical evaluation of a restorative resin with organic filler. Preliminary report and discussion. Aust. dent. J., v.24, n.6, p.402-7, Dec. 1979.

27. BUONOCORE, M. G. A simple method of increasing the adhesion of acrylic fillings material to enamel surfaces. J. dent. Res., v.34, n.6 , p.849-53, Dec. 1955.

28. BURKE, F. J. T.; EARP, D. P.; FARRELL, S. Effectiveness of light-curing units. Brit. dent. J., v.181, n.8, p.283, Oct. 1996.

29. BURKE, F. J. T. et al. Restoration longevity and analysis of reasons for the placement and replacement of restorations provided by vocational dental practitioners and their trainers in the United Kingdom. Quintessence Int., v.30, n.4, p.234-42, Apr. 1999.

30. CARVALHO, R. M. et al. A review of polymerization contraction: the influence of stress development versus stress relief. Oper. Dent., v.21, n.1, p.17-24, Jan./Feb. 1996.

31. CASTAÑEDA ESPINOSA, J. C.; SABATINI, L. S. G.; MAURO, S. J. Resinas compostas. Bauru, FOB-USP, 1989. 35p. /Seminário apresentado à disciplina de Materiais Dentários Aplicados à Dentística Restauradora/

32. CÉSAR, J. A. et al. Avaliação clínica de preparos cavitários para restauração de dentes anteriores fraturados. Estomat. cult., v.16, n.2, p.23-6, abr./jun.1986. 
33. CHACON, M.; FRANCO, E. B. Extensão de polimerização de resina composta em função de cunhas refletivas. In: Jornada Odontológica de Bauru, 7, Bauru, 1994. Anais. Bauru, FOB-USP, 1994. p.42. /Res. G34/

34. CHANDLER, H. H. et al. Clinical evaluation of a radiopaque composite restorative material after three and a half years. J. dent. Res., v.52, n.5, p.1128-37, Sept./Oct. 1973.

35. CHRISTENSEN, R. P.; CHRISTENSEN, G. J. In vivo comparison of microfilled and a composite resin: A three-year report. J. prosth. Dent., v.48, n.6, p.657-63, Dec. 1982.

36. CIAMPONI, A. L.; DEL PORTILLO LUJAN, V. A.; SANTOS, J. F. F. Effectiveness of reflective wedges on the polymerization of composite resins. Quintessence Int., v.25, n.9, p.599-602, Sept.1994.

37. COOK, W. D. Factors affecting the depth of cure of UV-polymerized composites. J. dent. Res., v.59, n.5, p.800-8, May 1980.

38. COOK, W. D. Polymerization defects in composite resins. In: VANHERLE, G.; SMITH, D. C. International Symposium on Posterior Composite - Resin Dental Restorative Materials. Netherlands, Peter Szulc Publishing, 1985. Section IV, p.273-86.

39. COOK, W. D.; McAREE, D. C. Optical properties of esthetic restorative materials and natural dentition. J. Biomed Mater. Res., v.19, n.5, p.469-88, May/June 1985.

40. CRABB, H. S. M. The survival of dental restorations in a teaching hospital. Brit. dent. J., v.150, n.11, p.315-8, June 1981. 
41. CRISP, R. J.; BURKE, F. J. T. One-year clinical evaluation of F2000 restorations placed in general dental practice. J. dent. Res., v. 78, p.230, 1999. Special issue. /Abstract 2288/

42. CRUMPLER, D. C. et al. Five-year clinical investigation of one conventional composite and three microfilled resins in anterior teeth. Dent. Mat., v.4, n.4, p.217-22. Aug. 1988.

43. CVAR, J. F.; RYGE, G. Criteria for the clinical evaluation of dental restorative materials. Washington, D.C., US Dept. of Health, Education and Welfare, 1973 apud NAVARRO ${ }^{120}$ p.47-50.

44. DAVIDSON, C. L.; DE GEE., A. J.; FEILZER, A. J. The competition between the composite-dentin bond strength and the polymerization contraction stress. J. dent. Res., v.63, n.12, p.1396-9, Dec. 1984.

45. DAVIS, R. D.; MAYHEW, R. B. A clinical comparison of three anterior restorative resins at 3 years. J. Amer dent. Ass., v.112, n.5, p.659-63, May 1986.

46. DE GEE, A. J.; TEN HARKEL-HAGENAAR, E.; DAVIDSON, C. L. Color dye identification of incompletely cured composite resins. J. prosth. Dent., v.52, n.5, p.626-31, Nov. 1984 apud SHORTALL; WILSON; HARRINGTON ${ }^{155}$ p.337.

47. DE LANGE, C.; BAUSCH, J. R.; DAVIDSON, C. L. The curing pattern of photoinitiated dental composites. J. oral Rehab., v.7, n.5, p.369-77, Sept. 1980.

48. DINELLI, W. et al. Avaliação clínica de alguns materiais de restauração para dentes anteriores - Parte II - Integridade marginal. Rev. Ass. paul. cirurg. Dent., v.28, n.4, p.224-7, jul./ago.1974.

49. DOGON, I. L. et al. Three year comparison of light cured vs chemically cured microfilled materials. J. dent. Res., v.64, p.353, 1985. Special issue. /Abstract 1603/ 
50. DRAUGHN, R. A. Fatigue and fracture mechanics of composite resins. In: VANHERLE,

G.; SMITH, D. C. International Symposium on Posterior Composite - Resin Dental - Restorative Materials. Netherlands, Peter Szulc Publishing, 1985. Section IV, p.299-308.

51. DUPERON; D. F., NEVILLE; M. D., KASLOFF, Z. Clinical evaluation of corrosion resistance of conventional alloy, spherical particle alloy and dispersion phase alloy. J. prosth. Dent., v.25, n.6, p.650-6, June 1971 apud KNIBBS ${ }^{95}$ p.116.

52. EICK, J. D. In vivo wear measurement of composite resins. p.351-64. In: VANHERLE, G.; SMITH, D. C. International Symposium on Posterior Composite - Resin Dental - Restorative Materials. Netherlands, Peter Szulc Publishing, 1985. Section II, pág. 352.

53. ELDERTON, R. J. Assessment of the quality of restorations - a literature review. J. oral Reabil., v.4, n.3, p.217-26, July 1977.

54. ELDIWANY, M.; FRIEDL, K. H.; POWERS, J. M. Color stability of light-cured and post-cured composites. J. dent. Res., v.73, part I, p.126, Jan./Mar. 1994. Special issue. /Abstract 198/

55. ERIKSEN, H. M. Indirect clinical methods for evaluation of resin filling materials. Int. dent. J., v.30, n.4, p.359-63, Dec. 1980.

56. FAN, P. L. Polymerization defects. In: VANHERLE, G.; SMITH, D. C. International Symposium on Posterior Composite - Resin Dental - Restorative Materials. Netherlands, Peter Szulc Publishing, 1985. Section IV, p.287-98.

57. FEILZER, A. J.; DE GEE., A. J.; DAVIDSON, C. L Increased wall-to-wall curing contraction in thin bonded resin layers. J. dent. Res., v.68, n.1, p.48-50, Jan. 1989. 
58. FEILZER, A. J. et al. Influence of light intensity on polymerization shrinkage and integrity of restoration - cavity interface. Europ. J. oral Sci., v.103, n.5, p.322-6, 1987.

59. FERRACANE, J. L.; GREENER, E. H. Fourier transform infrared analysis of degree of polymerization in unfilled resins - Methods comparison. J. dent. Res., v.63, n.8, p.1093-5, Aug. 1984 apud FERRACANE; MOSER; GREENER ${ }^{60}$ p.486.

60. FERRACANE, J. L.; MOSER, J. B.; GREENER, E. H. Ultraviolet light induced yellowing of dental restorative resins. J. prosth. dent., v.54, n.4, p.483-7, Oct.1985.

61. FLYNN, M. SEM investigation of in-vivo performance of twelve tooth colored restorative materials. J. dent. Res., v.55, p.191, 1976. Special issue B. /Abstract 520/

62. FLYNN, M. Scanning electron microscope investigation of in vivo performance of light composite resins. J. prosth. dent., v.39, n.5, p.529-32, May 1978.

63. FONTANA, U.F. et al. Avaliação clínica de alguns materiais de restauração para dentes anteriores. Parte I - contorno ou perda de material e descoloração marginal. Rev. Ass. paul. cirurg. Dent., v.28, n.2, p.113-22, mar./abr. 1974.

64. FRIEND, L. A.; JACOBSEN, P. H.; BEAL, J.F. Handling properties of a composite anterior restorativa material. An investigation. Brit. dent. J., v.129, n.2, p.70-5, July 1970.

65. GABRIELLI, F. et al. Avaliação clínica de alguns materiais de restauração para dentes anteriores (Parte III) Recidiva de cárie e descombinacão em cor. Rev. Ass. paul. cirurg. Dent., v.29, n.1, p.18-24, jan./fev. 1975.

66. GALAN JUNIOR, J. et al. Estudo comparativo de alguns tipos de avaliação clínica para amálgama. Rev. gaúcha Odont., v.30, n.2, p.105-10, abr./jun. 1982. 
67. GALAN JUNIOR, J. et al. Ranking fotográfico de restaurações estéticas. Rev. gaúcha Odont., v.33, n.4, p.337-40, out./dez. 1985.

68. GLANTZ, P. Surface roughness of composite resins before and after finishing. Acta.odont.Scand. ,v.30, p.335-47, 1972.

69. GOLDSTEIN, G. R.; LERNER, T. The effect of toothbrushing on a hybrid composite resin. J. prosth. Dent., v.66, n.4, p.498-500, Oct. 1991.

70. HANSEN, E. K. Marginale spalter ved anvendelse af mikrofyldte plastmaterialer i ikkeemaljebeklaedte kaviteter. Tandlägebladet, v.85, p.70-5, 1981 apud HANSEN; $\operatorname{ASMUSSEN}^{76}$ p.122, 125, 126.

71. HANSEN, E. K. Visible light-cured composite resins: polymerization contraction, contraction pattern and hygroscopic expansion. Scand. J. dent. Res., v.90, n.4, p.329-35, 1982 apud HANSEN; ASMUSSEN $^{76}$ p.122, 125, 126.

72. HANSEN, E. K. Effect of Scotchbond dependent on cavity cleaning, cavity diameter and cavosurface angle. Scand. J. dent. Res., v.92, n.2, p.141-7, 1984 apud HANSEN; $\operatorname{ASMUSSEN}^{76}$ p.126.

73. HANSEN, E. K. Effect of three dentin adhesives on marginal adaptation of two lightcured composites. Scand. J. dent. Res., v.94, n.1, p.82-6, 1986 apud HANSEN; $\operatorname{ASMUSSEN}^{76}$ p.126.

74. HANSEN, E. K.; ASMUSSEN, E. Comparative study of dentin adhesives. Scand. J. dent. Res., v.93, n.5, p.474-9, 1985 apud HANSEN; ASMUSSEN $^{76}$ p.122, 126.

75. HANSEN, E. K.; ASMUSSEN, E. Effect of postponed polishing on marginal adaptation of resin used with dentin-bonding agent. Scand. J. dent. Res., v.96, p.260-4, 1988 apud HANSEN; ASMUSSEN ${ }^{76}$ p.126. 
76. HANSEN, E. K.; ASMUSSEN, E. Marginal adaptation of posterior resins: Effect of dentin-bonding agent and hygroscopic expansion. Dent. Mat., v.5, n.2, p.122-6, Mar.1989.

77. HANSEN, E. K. et al. Clinical short term study of marginal integrity of resin restorations. Scand. J. dent. Res., v.92, n.4, p.374-9, 1984.

78. HASHINGER, D. T.; FAIRHURST, C. W. Thermal expansion and filler content of composite resins. J. prosth. Dent., v.52, n.4, p.506-10, Oct. 1984 apud VERSLUIS; DOUGLAS; SAKAGUCHI ${ }^{193}$ p.290.

79. HENCHANG, X.; WENYI, L.; TONG, W. Measurement of thermal expansion coefficient of human teeth. Aust. dent. J., v.34, p.530-5, 1989 apud VERSLUIS; DOUGLAS; SAKAGUCHI ${ }^{193}$ p.290.

80. INOKOSHI, S.; YAMADA, T.; TAKATSU, T. Opacity and color changes of direct tooth colored restoratives. J. dent. Res., v.73,part I, p.126, Jan./Mar. 1994. Special issue. /Abstract 197/

81. JACOBSEN, P. H. Clinical aspects of composite restorative materials. Brit. dent. J., v.139, n.7, p.276-80, Oct. 71975.

82. JENDRESEN, M. D. Clinical behavior of $21^{\text {st }}$ - century adhesives and composites. Quintessence Int., v.24, n.9, p.659-62, Sept. 1993.

83. JENDRESEN, M. D. et al. Annual review of selected dental literature: report of the committee on Scientific Investigation of the American Academy of Restorative Dentistry. J. prosth. Dent., v.74, n.1, p.60-99, July 1995.

84. JENSEN, M. E.; CHAN, D. C. N. Polymerization shrinkage and microleakage. In: VANHERLE, G.; SMITH, D. C. International Symposium on Posterior 
Composite - Resin Dental - Restorative Materials. Netherlands, Peter Szulc Publishing, 1985. Section IV, p.243-62.

85. JOHNSON, L. N. et al. Effects of various finish devices on resin surfaces. J. Amer. dent. Ass., v.83, p.321-31, 1971.

86. JOKSTAD, A. et al. Clinical performance of three anterior restorative materials over 10 years. Quintessence Int., v.25, n.2, p.101-8, Feb. 1994.

87. JÖRGENSEN, K. D. Fatigue and fracture mechanics of composite resins. In: VANHERLE, G.; SMITH, D. C. International Symposium on Posterior Composite - Resin Dental - Restorative Materials. Netherlands, Peter Szulc Publishing, 1985. Section IV, p.309-16.

88. JÖRGENSEN, K. D. et al. Composite wall-to-wall polymerization contraction in dentin cavities treated with various bonding agents. Scand. J. dent. Res., v.93, n.3, p.276-9, 1985 apud HANSEN; ASMUSSEN ${ }^{76}$ p.126.

89. KAWAI, K.; LEINFELDER, K. F. Effects on surface pre-treating sealant on composite wear. Dent. Mat., v.9, n.2, p.108-13, Mar. 1993.

90. KELSEY, W. P. et al. The effects of wand positioning on the polymerization of composite resin. J. Amer. dent. Ass., v.114, n.2, p.213-5, Feb. 1987.

91. KHOKHAR, Z. A.; RAZZOOG, M. E.; YAMAN, P. Color stability of restorative resins. Quintessence Int., v.22, n.9, p.733-7, Sept. 1991.

92. KIDD, E. A. M. Polymerization shrinkage and microleakage. In: VANHERLE, G.; SMITH, D. C. International Symposium on Posterior Composite - Resin Dental Restorative Materials. Netherlands, Peter Szulc Publishing, 1985. Section IV, p.263-8. 
93. KIDD, E. A. M.; BEIGHTON, D. Prediction of secondary caries around tooth-colored restorations: a clinical and microbiological study. J. dent. Res., v.75, n.12, p.1942-6, Dec. 1996.

94. KING, N. M.; YUNG, L. K. M.; HOLMGREN, C. J. Clinical performance of preventive resin restorations placed in a hospital environment. Quintessence Int., v.27, n.9, p.627-32, Sept.1996.

95. KNIBBS, P. J. Review - methods of clinical evaluation of dental restorative materials. J. oral Rehab., v.24, n.2, p.109-23, Feb.1997.

96. KOMATSU, M.; FINGER, W. Dentin bonding agents: Correlation of early bond strength with margin gaps. Dent. Mat., v.2, p.257-62, 1986 apud HANSEN; ASMUSSEN ${ }^{76}$ p.126.

97. LAMBRECHTS, P.; VANHERLE, G. The use of glasing materials for finish dental composite resin surfaces. J. oral. Rehab., v.9, p.107-17, 1982.

98. LAMBRECHTS, P. et al. Aesthetic limits of light-cured composite resins in anterior teeth. Int. dent. J., v.40, n.3, p.149-58, June 1990.

99. LARATO, D. C. Influence of a composite resin restoration on the gingiva. J. prosth. Dent., v.28, n.4, p.402-4, Oct. 1972.

100. LEE, S. Y.; GREENER, E. H. Effect of excitation energy on dentine bond strength and composite properties. J. Dent., v.22, n.3, p.175-81, June 1994 apud JENDRESEN et al. ${ }^{83}$ p.85.

101. LEINFELDER, K. F.; SLUDER, T. B.; SANTOS, J. F. F. Five year clinical evaluation of anterior and posterior composites. J. dent. Res., v.57, p.339, Jan. 1978. Special issue A. /Abstract 1058/ 
102. LEINFELDER, K. F. et al. Clinical evaluation of composite resin as anterior and posterior restorative material. J. prosth. Dent., v.33, n.4, p.407-16, Apr. 1975.

103. LIATUKAS, E. L. A clinical investigation of composite resin restorations in anterior teeth. J. prosth. Dent., v.27, n.6, p.616-21, June 1972.

104. LUNDIN, S. A.; KOCH, G. Cure profiles of visible-light-cured Class II composite restorations in vivo and in vitro. Dent. Mat., v.8, p.7, 1992, apud SHORTALL; WILSON; HARRINGTON ${ }^{155}$ p.337.

105. MAHLER, D. B. et al. Marginal fracture vs. mechanical properties of amalgam. J. dent. Res., v.49, n.6, p.1452-7, Nov./Dec. 1970.

106. MARTIN, F. E. A survey of the efficiency of visible light curing units. J. Dent., v.26, n.3, p.239-43, Mar.1998.

107. MARYNUIK, G. A. In search of treatment longevity - a 30-year perspective. J. Amer. Dent. Ass., v.109, n.5, p.739-44, Nov. 1984.

108. McCABE, J. F. In vitro wear testing of composite resins. In: VANHERLE, G.; SMITH, D. C. International Symposium on Posterior Composite - Resin Dental Restorative Materials. Netherlands, Peter Szulc Publishing, 1985. Section IV, p.319-30.

109. McCONNELL, R. J. et al. Dimension change during setting of composite resin. J. dent. Res., v.73, part I, p.126, Jan./Mar. 1994. Special issue. /Abstract 196/

110. McKINNEY, J. E. Environmental damage and wear of dental composite restoratives. In: VANHERLE, G.; SMITH, D. C. International Symposium on Posterior Composite - Resin Dental - Restorative Materials. Netherlands, Peter Szulc Publishing, 1985. Section IV, p.331-47. 
111. McLEAN, J. W.; SHORT, I. G. Composite anterior filling materials. A clinical and physical appraisal. Brit. dent. J., v.127, n.1, p. 9-18, July 1969.

112. MENEZES, M. A.; MUENCH, A. Dureza Knoop de resinas compostas em função do número relativo de radicais livres. Rev. Odont. USP, v.12, n.3, p.281-5, jul./set. 1998.

113. MILLAR, B. J.; ROBINSON, P. B.; INGLIS, A. T. Clinical evaluation of an anterior hybrid composite resin over 8 years. Brit. dent. J., v.182, n.1, p.26-30, Jan.1997.

114. MITCHEM, J. C. Correlation of laboratory testing to three-year clinical behaviour of silicate cements. J. prosth. Dent., v.27, n.2, p.172-5, Feb. 1972.

115. MJÖR, I. A. Orsaker till revision av fyllningar. Tandläkartidningen, v.71, p.552, 1979 apud ERIKSEN ${ }^{55}$ p.360, 361.

116. MONDELLI, J. et al. Proteção do complexo dentinopulpar. São Paulo, Artes Médicas, 1998. Cap.3, p.29-57; Cap.8, p.215-49.

117. MONDELLI, J. et al. Restaurações estéticas. São Paulo, Sarvier, 1984. Cap.2, p.7-14.

118. MUNKSGAARD, E. C.; HANSEN, E. K.; ASMUSSEN, E. Effect of five adhesives on adaptation of resin in dentin cavities. Scand. J. dent. Res., v.92, p.480-3, 1984 apud HANSEN; ASMUSSEN ${ }^{76}$ p.126.

119. NAGEM FILHO, H. Resina Composta. Grupo Brasileiro de Materiais Dentários. 1988. $19 \mathrm{p}$.

120. NAVARRO, M. F. L. Avaliação clínica de restaurações estéticas. Bauru, 1981. 211p. Tese (Livre-Docência). Faculdade de Odontologia de Bauru, Universidade de São Paulo. 
121. NAVARRO, M. F. L.; PASCOTTO, R. C. Cimentos de ionômero de vidro: aplicações clínicas em odontologia. São Paulo, Artes Médicas, 1998. Cap.1, p.1-21; Cap.5, p.87-148.

122. NAVARRO, M. F. L.; PALMA, R. G.; DEL'HOYO, R. B. O que é preciso saber a respeito de ionômero de vidro? Inovações - vantagens e desvantagens. In: FELLER, C.; BOTTINO, M. A. Atualização na clínica odontológica: a prática da clínica geral. São Paulo, Artes Médicas, 1994. Cap.4, p.61-74.

123. NEO, J.; CHEW, C. Direct tooth-colored materials for noncarious lesions: a 3-year clinical report. Quintessence Int., v.27, n.3, p.183-8, Mar. 1996.

124. NEO, J. et al. Clinical evaluation of tooth-colored materials in cervical lesions. Amer. J. dent., v.9, n.1, p.15-8, Feb. 1996.

125. ONOSE, H. et al. Selected curing characteristics of light-activated composite resins. Dent. Mat., v.1, n.2, p. 48-54, Apr. 1985.

126. ORAM, V.; LYDERS, B. Marginal defects of etched and unetched composite resin restorations. A 2-year clinical investigation. J. dent. Res., v.60, p.1246, 1981. Special issue. /Abstract 12/

127. OSBORNE, J. W. et al. Three-year clinical comparison of three amalgam alloy types emphasizing an appraisal of the evaluation methods used. J. Amer. dent. Ass., v.93, n.4, p.784-9, Oct. 1976.

128. OYSAED, H.; RUYTER, I. E. Composites for use in posterior teeth: Mechanical properties tested under dry and wet conditions. J. Biomed. Mater. Res., v.20, n.2, p. 261-71, Feb. 1986 apud HANSEN; ASMUSSEN ${ }^{76}$ p.125. 
129. PAFFENBARGER, G. Silicate cement: na investigation by a group of practicing dentists under the direction of the ADA research fellowship at the National Bureau of Standards. J. Amer. dent. Ass., v.27, n.10, p.1611-22, Oct. 1940.

130. PATERSON, N. The longevity of restorations. A study of 200 regular attenders in a general dental practice. Brit. dent. J., v.157, n.1, p. 23-5, July 1984.

131. PERDIGÃO, J. et al. The interaction of adhesives systems with human dentin. Amer. J. Dent., v.9, n.4, p.167-73, Aug. 1996.

132. PHILLIPS, R. W. Past, present and future composite resin systems. Dent. Clin. N. Amer., v.25, n.2, p.209-18, Apr. 1981.

133. PHILLIPS, R.W. Skinner: materiais dentários. 9 ed. Rio de Janeiro, Guanabara Koogan, 1993. Cap.3, p.16-34; Cap.10, p.91-102 e Cap.12, p.124-43.

134. PILO, R.; CARDASH, H. S. Post-irradiation polymerization of different anterior and posterior visible light-activated resin composites. Dent. Mat., v.8, n.5, p.299-304, Sept. 1992.

135. QVIST, V.; QVIST, J.; MJÖR, I. A. Placement and longevity of tooth-colored restorations in Denmark. Acta odont. Scand., v.48, n.5, p.305-11, 1990.

136. RAMOS, D. L. P.; GRANDE, R. H. M. A ética na pesquisa odontológica. Informe da SBPqO - Divisão Brasileira IADR. v.1, n.3, p.1-4, jun. 1998.

137. REEKIE, D. The editor's choice - "Research in general dental practice". Brit. dent. J., v.176, n.3, p.88, Feb. 1994.

138. RESINAS compostas condensáveis. Dent. Adv., v.5, n.8, p.1-12, set. 1998.

139. RETIEF, D. H. The principles of adhesion. J. dent. Ass. S. Afr., v.25, n.9, p.285-95, 1970. 
140. RIBBONS, J. W. Handling properties of a new composite filling material. Brit. dent. J., v.129, n.11, p.509-12, Dec. 1970.

141. RIBBONS, J. W.; PEARSON, G. J. A composite filling material. A two-year clinical assessment. Brit. dent. J., v.134, n.9, p.389-91, May 1973.

142. ROULET; J. F. Margin integrity: clinical significance. J. Dent., v.22, p.S9-S12, 1994. Supplement 1.

143. ROULET, J. F.; SEEWALDT, A.; NOACK, M. J. Margin quality of class III and IV composites in vitro. Dent. Mat. v.7, n.3, p.179-85, July 1991.

144. RUEGGEBERG, F. A. et al. A predictive model for the polymerization of photoactivated resin composites. Int. J. Prosthodont., v.7, p.159-66, 1994 apud JENDRESEN et al. ${ }^{83} \mathrm{p} .85$.

145. RUPP, N. W. Clinical placement and performance of composite resin restorations. J. dent. Res., v.58, n.5, p.1551-7, May 1979.

146. RYGE, G. Clinical criteria. Int. dent. J., v.30, n.4, p.347-58, Dec. 1980.

147. RYGE, G.; CVAR, J.F. Clinical evaluation of new and conventional anterior restorative materials. Symposium on recent advances in dental materials, Federation Dentaire Internationale, Israel, 1966 apud GALAN JUNIOR et al. ${ }^{66}$ p. 106.

148. RYGE, G.; SNYDER, M. Evaluating the quality of restorations. J. Amer. dent. Ass., v.87, n.2, p.369-77, Aug. 1973.

149. RYGE, G. et al. The assessment of clinical quality and professional performance. School of Dentistry, University of the Pacific, 1973 apud GALAN JUNIOR et al. ${ }^{66}$ p.105, 106.

150. RYGE, G. et al. Standardization of clinical investigators for studies of restorative materials. Swed. dent. J., v.5, n.516, p.235-9, 1981. 
151. SÁ, F. C. et al. Evaluation of antimicrobial activity of base and restorative materials: an in vitro study. J. dent. Res., v.75, p.316, 1996. Special issue. /Abstract 2390/

152. SALEH, N. et al. One-year clinical evaluation of na anterior composite resin. Quintessence Int., v.23, n.8, p.559-67, Aug. 1992.

153. SANTOS, A.; RIBEIRO, S. A.; STEAGALL, L. Estudo das modificações nos aspectos clínicos de alguns materiais restauradores estéticos quando submetidos à ação da saliva. Rev. Ass. paul. cirurg. Dent., v.31, n.1, p.41-7, jan./fev. 1977.

154. SELA, M. et al. Adaptation of silicate and Adaptic to the margins of cavities. A scanning electron microscope study. J. oral Rehab., v.2, n.2, p.117-24, Apr. 1975.

155. SHORTALL, A. C.; WILSON, H. J.; HARRINGTON, E. Depth of cure of radiationactivated composite restoratives - Influence of shade and opacity. J. oral Rehab., v.22, n.5, p.237-422, May 1995.

156. SILVA E SOUZA JUNIOR, M. H. Procedimentos restauradores estéticos em resina e porcelana para dentes posteriores. Rev. dent. Rest., v.1, n.1, p.1-61, jan./mar. 1998.

157. SILVA E SOUZA JUNIOR, M. H.; YAMAUTI, M. Two year clinical evaluation of three different composite resin systems. J. dent. Res., v.78, p.230, 1999. Special issue. /Abstract 997/

158. SKJORLAND, K. K. R. Plaque accumulation on different dental filling materials. Scand. J. dent. Res., v.81, p.538, 1973 apud DAVIS; MAYHEW ${ }^{45}$ p.659.

159. SMALES, R. J. Composite resin restorations. A three-year clinical assessment of four materials. Aust. dent. J., v.20, n.4, p.228-34, Aug. 1975.

160. SMALES, R. J. Composite resin restorations: a clinical assessment of two materials. J. Dent., v.5, n.4, p.319-26, Dec. 1977. 
161. SMALES, R. J. Clinical use of ASPA glass-ionomer cement. Brit. dent. J., v.151, n.1, p.58-60, July 1981.

162. SMALES, R. J. Evaluation of clinical methods for assessing restorations. J. prosth. Dent., v.49, n.1, p.67-70, Jan. 1983.

163. SMALES, R. J. Effects of enamel-bonding, type of restoration, patient age and operator on the longevity of an anterior composite resin. Amer. J. Dent., v.4, n.3, p.130-3, June 1991.

164. SMALES, R. J. Long-term deterioration of composite resin and amalgam restorations. Oper. Dent., v.16, n.6, p.202-9, Nov./Dec. 1991.

165. SMALES, R. J. Effect of rubber dam isolation on restoration deterioration. Amer. J. Dent., v.5, n.5, p.277-9, Oct. 1992.

166. SMALES, R. J. Rubber dam usage related to restoration quality and survival. Brit. dent. J., v.174, n.9, p.330-3, May 1993.

167. SMALES, R. J.; CREAVEN, P. J. Evaluation of three clinical methods for assessing amalgam and resin restorations. J. prosth. Dent., v.54, n.3, p.340-6, Sept. 1985.

168. SMALES, R. J.; GERKE, D. C. Clinical evaluation of four anterior composite resins over five years. Dent. Mat., v.8, n.4, p.246-51, July 1992.

169. SMALES, R. J.; GERKE, D. C. Clinical evaluation of light-cured anterior resin composites over periods of up to 4 years. Amer. J. Dent., v.5, n.4, p.208-12, Aug. 1992.

170. SMALES, R. J.; WEBSTER, D. A ; LEPPARD, P. I. Survival predictions of four types of dental restorative materials. J. Dent., v.19, n.5, p.278-82, Oct. 1991 apud BROWNING; DENNISON ${ }^{25}$ p. 165. 
171. SOCKWELL, C. L. Clinical evaluation of anterior restorative materials. Dent. Clin. N. Amer., v.20, n.2, p.403-22, Apr. 1976.

172. SÖDERHOLM, K. J. Degradation of glass filler in experimental composites. J. dent. Res., v.60, n.11, p.1867-75, Nov. 1981 apud HANSEN; ASMUSSEN $^{76}$ p.125.

173. SÖDERHOLM, K. J. Leaking of fillers in dental composites. J. dent. Res., v.62, n.2, p.126-30, Feb. 1983 apud VANHERLE; SMITH ${ }^{188}$ p.134.

174. SÖDERHOLM, K. J. Hydrolytic degradation of dental composites and effects of silanetreatment and filler fraction on compressive strength and thermal expansion of composites. Odontol. Diss. Umea Univ., v.19, 1984 apud VANHERLE; SMITH ${ }^{188}$ p.134.

175. SÖDERHOLM, K. J. et al. Hydrolytic degradation of dental composites. J. dent. Res., v.63, n.10, p.1248-54, Oct. 1984 apud HANSEN; ASMUSSEN $^{76}$ p.125.

176. STANFORD, J. W.; RYGE, G. Recommended outline for a research protocol. Int. dent. J., v.27, n.1, p.43-5, Mar.1977.

177. STANFORD, J. W.; RYGE, G. Recommended format for protocol for clinical research program. Clinical comparison of several anterior and posterior restorative materials. Int. dent. J., v.27, n.1, p.46-57, Mar.1977.

178. STANFORD, J. W.; RYGE, G. Recommendations for clinical research protocols for dental materials. Int. dent. J., v.32, n.4, p.403-23, Dec. 1982.

179. STANFORD, W. B. et al. Effect of finishing on color and gloss of composites with different fillers. J. Amer. dent. Ass., v.110, n.2, p.211-3, Feb.1985.

180. STANINEC, M. Summaries of clinically relevant studies of dental materials from the 1994 meeting of the International Association for Dental Research. Gen. Dent., v.43, n.3, p.278-90, May/June 1995. 
181. SVANBERG, M.; MJÖR, I. A.; ORSTAVIK, D. Muttans streptococci in plaque from margins of amalgam, composite and glass ionomer restorations. J. dent. Res., v.69, n.3, p.861-4, Mar. 1990.

182. TAY, W. M. et al. An assessment of anterior restorations "in vivo" using the scanning electron microscope - Results after 3 years. Brit. dent. J., v.146, n.3, p.71-6, Feb.1979.

183. TIMMONS, J. H.; LASWELL, H. R.; ROBINSON, F. B. A three-year clinical study of eight anterior composite resins. J. dent. Res., v.64, p.254, Mar. 1983. /Abstract 763/

184. TORSTENSON, B.; BRÄNNSTRÖM, M. Contraction gap under composite resin restorations: effect of hygroscopic expansion and termal stress. Oper. dent., v.13, n.1, p.24-31, Winter 1988.

185. UM, C. M., RUYTER, I. E. Staining of resin-based veneering materials with coffee and tea. Quintessence Int., v.22, n.5, p.377-86, May 1991.

186. UNO, S.; ASMUSSEN, E. Marginal adaptation of a restorative resin polymerized at a reduced rate. Scand. J. dent. Res., v.99, n.5, p.440-4, Oct. 1991.

187. UNTERBRINK, G. L.; MUESSNER, R. Influence of light intensity on two restorative systems. J. Dent, v.23, n.3, p.183-9, June 1995.

188. VANHERLE, G.; SMITH, D. C. International Symposium on Posterior Composite Resin Dental - Restorative Materials. Netherlands, Peter Szulc Publishing, 1985. Section II, p.71-160.

189. VAN DIJKEN, J. W. A clinical evaluation of anterior conventional, microfiller, and hybrid composite resin fillings. A 6-year follow-up study. Acta odont. Scand., v.44, n.6, p357-67, 1986. 
190. VAN DIJKEN, J. W. et al. Effect of finish procedures on surface textures of some resin restoratives. Acta odont. Scand., v.38, p293-301, 1980.

191. VAN MEERBEEK, B. et al. The clinical performance of adhesives. J. Dent., v.26, n.1, p.1-20, Jan. 1998.

192. VAN NOORT, R.; DAVIS, L. G. A propective study of the survival of chemically activated anterior resina composite restorations in general dental practice: 5-year results. J. Dent., v.21, n.4, p.209-15, Aug. 1993.

193. VERSLUIS, A.; DOUGLAS, W. H.; SAKAGUCHI, R. L. Thermal expansion coefficient of dental composites measured with strain gauges. Dent. Mat., v.12, n.5, p.290-4, Sept. 1996.

194. VIEIRA, D. F. Resinas compostas. Rev. gaúcha. Odont., v.27, n.2, p.101-8, abr./jun. 1979.

195. VIOHL, J. Clinical assessment of the colour stability of resin filling materials. Int. dent. J., v.31, n.1, p.39-44, 1981.

196. WILDER, A. D.; MAY, K. N.; LEINFELDER, K. F. Five-year clinical clinical study of U.V. polymerized composites in posterior teeth. J. dent. Res., v.63, p.337, 1984. Special issue. /Abstract 1497/

197. WILSON, N. H. F. The evaluation of materials: relationships between laboratory investigations and clinical studies. Oper. Dent., v.15, n.4, p.149-55, July/Aug. 1990.

198. WILSON, C. J.; RYGE, G. Clinical study of dental amalgam. J. Amer. dent. Ass., v.66, n.6, p.763-71, June 1963.

199. WOZNIAK, W. T. et al. Photographic assessment of colour changes in cold and heatcure resins. J. oral Rehab., v.8, n.4, p.333-9, July 1981 apud UM; RUYTER ${ }^{185}$ p.377. 
200. YEARN, J. A. Factors affecting cure of visible light activated composites. Int. dent. J., v.35, n.3, p.218-25, 1985. 
ABSTRACT 


\section{ABSTRACT \\ Clinical evaluation of Class III restorations using two composite resins.}

The purpose of this study was to clinically evaluate two composite resins at 2-year period. Seventy Class III restorations were made by only one operator, 35 with Z-100 composite resin and 35 with Fill Magic. The teeth were selected based on clinical exams. Restorations included only anterior superior teeth. Following cavity preparations, under rubber dam, they were protected with calcium hydroxide and/or a glass ionomer base. Magic Adhesiv/Fill Magic (Vigodent) and Scotchbond Multipurpose Plus/Z-100 (3M) were used for adhesion to exposed dentin and enamel and restoration of the cavities. The cavities were restored in increments. Restorations were finished using multi-laminated burs, Sof-Lex discs and Enhance System. Evaluation was assessed after finishing and polishing approximately one week after placement (baseline), 6 months, 1 year and 2 years using the modified Ryge criteria for color, marginal discoloration, anatomic form, marginal integrity, secondary caries and post-operative sensitivity. There were three levels of scores for each category: good (0), acceptable (1) and unacceptable (2). Only for secondary caries there were 2 levels: absent (0) and present (1). Besides, it was investigated the occurrence of postoperative sensitivity, which was classified as the other scores were for another characteristics observed. At every evaluation, impressions from the restorations were made and they were examined by scanning electron microscopy. At baseline, there was one score "one" for 
category color for Z-100 composite resin; the other restorations and the other composite resin were graded to be "zero". At 6 months recall, the restorations were assessed and there were four scores "one" for Z-100 composite resin. The restorations were evaluated at 1 year and the results were as follow: there were four scores "one" for Z-100 composite resin and one score "one" for Fill Magic composite resin with regard to color. At 2-year evaluation were observed three scores "one" for Z-100 composite resin and one score "one" for Fill Magic. Except for color category, all the restorations received score "zero" either for 6 months, 1-year and 2year recalls. No scores "two" were noted. The results were analyzed by Fisher Exact Statistical Test. No significant differences were noted between both composite resins. In conclusion, these two composite resins demonstrated excellent clinical acceptability in all categories assessed, making them suitable for anterior restorations. 